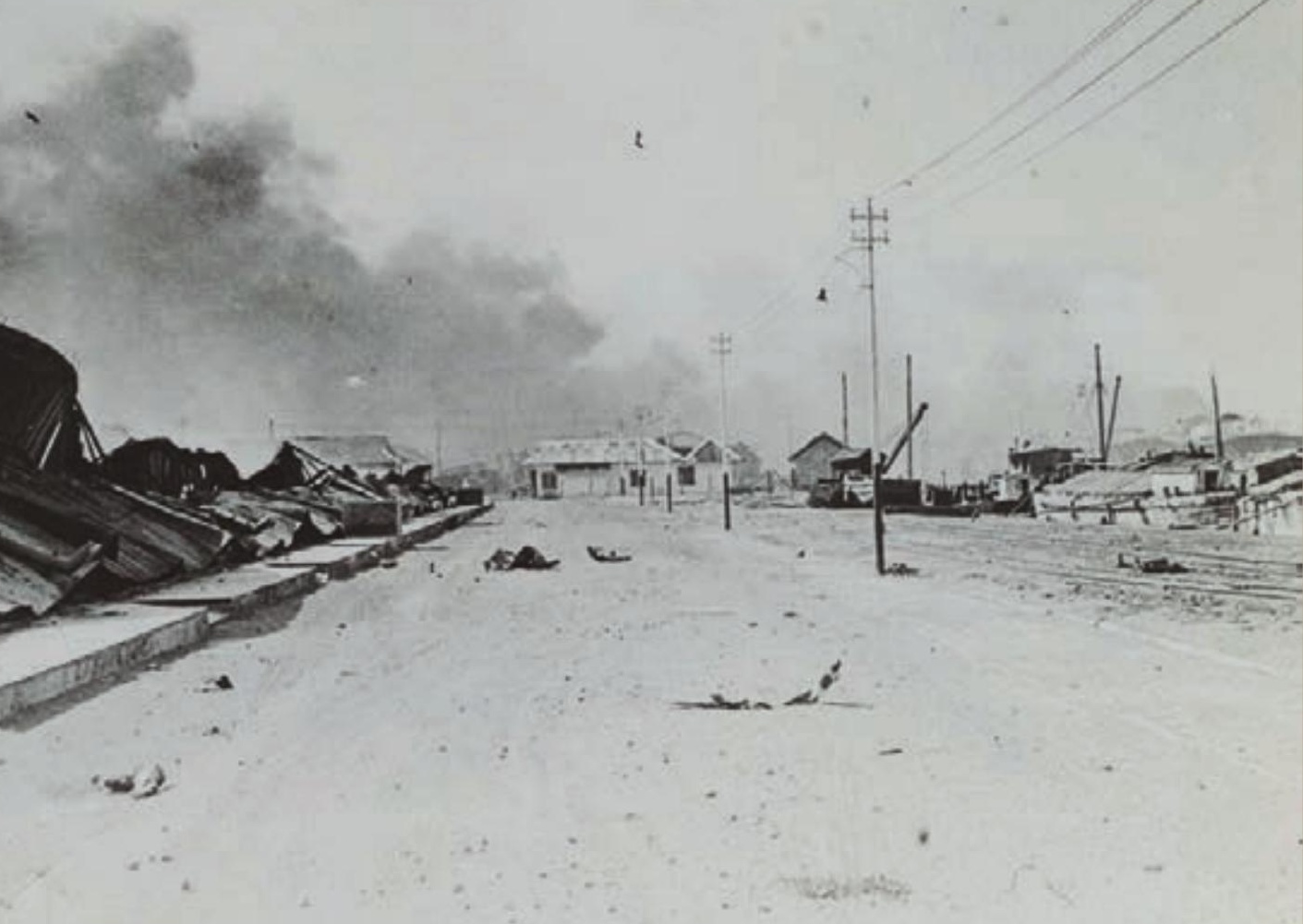

Paul M.M. Doolan

\title{
Collective Memory and the Dutch East Indies
}

Unremembering Decolonization 
Collective Memory and the Dutch East Indies 


\section{Heritage and Memory Studies}

This ground-breaking series examines the dynamics of heritage and memory from transnational, interdisciplinary and integrated approaches. Monographs or edited volumes critically interrogate the politics of heritage and dynamics of memory, as well as the theoretical implications of landscapes and mass violence, nationalism and ethnicity, heritage preservation and conservation, archaeology and (dark) tourism, diaspora and postcolonial memory, the power of aesthetics and the art of absence and forgetting, mourning and performative re-enactments in the present.

Series Editors

Ihab Saloul and Rob van der Laarse, University of Amsterdam, The Netherlands

Advisory Board

Patrizia Violi, University of Bologna, Italy

Britt Baillie, Cambridge University, United Kingdom

Michael Rothberg, University of Illinois, USA

Marianne Hirsch, Columbia University, USA

Frank van Vree, University of Amsterdam, The Netherlands 


\section{Collective Memory and the Dutch East Indies}

Unremembering Decolonization

Paul M.M. Doolan

Amsterdam University Press 
Cover illustration: Verschroeide aarde

Source: Rijksmuseum, ANEFO, Wikimedia Commons

Cover design: Coördesign, Leiden

Lay-out: Crius Group, Hulshout

$\begin{array}{ll}\text { ISBN } & 9789463728744 \\ \text { e-ISBN } & 9789048553075 \text { (pdf) } \\ \text { DOI } & 10.5117 / 9789463728744 \\ \text { NUR } & 697\end{array}$

(c) Paul M.M. Doolan / Amsterdam University Press B.V., Amsterdam 2021

All rights reserved. Without limiting the rights under copyright reserved above, no part of this book may be reproduced, stored in or introduced into a retrieval system, or transmitted, in any form or by any means (electronic, mechanical, photocopying, recording or otherwise) without the written permission of both the copyright owner and the author of the book.

Every effort has been made to obtain permission to use all copyrighted illustrations reproduced in this book. Nonetheless, whosoever believes to have rights to this material is advised to contact the publisher. 


\section{Table of Contents}

$\begin{array}{ll}\text { Abbreviations } & 7\end{array}$

$\begin{array}{ll}\text { Acknowledgements } & 9\end{array}$

Introduction 11

1 Collective Memory and Unremembering $\quad 15$

$\begin{array}{lr}\text { Collective Memory } & 15\end{array}$

$\begin{array}{lr}\text { Collective Unremembering } & 18\end{array}$

Historical Representation $\quad 20$

A Short Summary of Decolonization in the Dutch East Indies 22

2 Representations during the War $\quad 27$

$\begin{array}{ll}\text { The Press } & 27\end{array}$

Indonesia Calling: A Film $\quad 37$

Oeroeg: A Novella $\quad 43$

Historiography of the Conflict: Early Beginnings $\quad 5^{1}$

3 Post-decolonization: The First 2o Years, 1949-1969 63

$\begin{array}{ll}\text { The Great Unremembering } & 63\end{array}$

Loss $\quad 66$

$\begin{array}{ll}\text { The Existentialist } & 104\end{array}$

$\begin{array}{ll}\text { Victimhood } & 109\end{array}$

The Adventurer $\quad 112$

The Soldier $\quad 115$

$\begin{array}{ll}\text { The Historian } & 121\end{array}$

4 Breaking the Silence $\quad 135$

$\begin{array}{lr}\text { The Hueting Interview } & 136\end{array}$

$\begin{array}{ll}\text { The Role of the Public } & 147\end{array}$

5 Postmemory $\quad 169$

$\begin{array}{lr}\text { The Moluccan Attacks } & 170\end{array}$

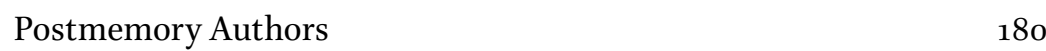

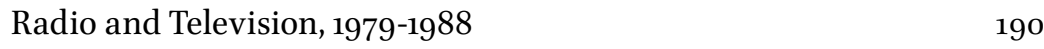


6 Loe de Jong Controversy 199

A Slow Change Coming 200

$\begin{array}{ll}\text { Silence of the Guild } & 207\end{array}$

$\begin{array}{ll}\text { Loe de Jong, Volume 11a } & 217\end{array}$

7 Remembering the War $\quad 233$

Ben Laurens: A Soldier Novelist $\quad 234$

Anton P. de Graaff and The Way Back 237

Oeroeg: The Film 252

The Boomsma Affair $\quad 260$

$\begin{array}{ll}\text { The Poncke Princen Affair } & 267\end{array}$

$\begin{array}{ll}\text { Television } & 270\end{array}$

The Guild Stirs $\quad 273$

8 Conclusion 297

$\begin{array}{ll}\text { Bibliography } & 305\end{array}$

$\begin{array}{ll}\text { Index } & 329\end{array}$ 


\section{Abbreviations}

AVRO Algemene Vereniging Radio Omroep (General Association of Radio Broadcasting)

DLC Dienst voor Legercontacten (Army Contact Service)

KITLV Koninklijk Instituut voor Taal-, Land- en Volkenkunde/ Royal Netherlands Institute of Southeast Asian and Caribbean Studies

KNIL KoninklijkNederlands-Indisch Leger (Royal Netherlands East Indies Army)

KRO Katholieke Radio Omroep (Catholic Radio Broadcaster)

KVP Katholieke Volkspartij (Catholic People's Party)

NCRV Nederlandse Christelijke Radio Vereniging (Dutch Christian Radio Association)

NICA Nederlandsch-Indische Civiele Administratie (Netherlands Indies Civil Administration)

NOS Nederlandse Omroep Stichting (Dutch Broadcast Foundation)

RMS Republik Maluku Seletan (Republic of South Moluccas)

RVD Rijksvoorlichtingsdienst (Government Information Service)

TNI Tentara Nasional Indonesia (Indonesian National Military)

VARA VARA Broadcasting Association; originally acronym for Vereeniging van Arbeiders Radio Amateurs (Association of Worker Radio Amateurs)

VPRO Vrijzinnig Protestantse Radio Omroep (Liberal Protestant Radio Broadcaster) 



\section{Acknowledgements}

This book is revised version of my dissertation submitted as a doctoral thesis to the University of Konstanz, Germany. The referees were Professors Anne Kwaschik (chair), Sven Trakulhun (supervisor) and Marcus Sandl. The oral examination took place on 15 July 2020.

Firstly, I wish to thank the members of my doctoral committee, Anne Kwaschik, Marcus Sandl and Sven Trakulhun. A huge thanks to Sven Trakulhun, who took on this project without really knowing what he was getting into and who never ceased to believe in it for the last decade or so. For commenting on an early draft of the first chapters, I would like to thank Gert Oostindie and Henk Schulte Nordholt of the Royal Netherlands Institute for Southeast Asian and Caribbean Studies (KITLV) in Leiden. Anne-Lot Hoek in Amsterdam and Jennifer Foray at Purdue University, USA, were both generous in sharing their ideas on some of the issues I discuss. A special thanks to Remco Raben at the University of Amsterdam for his encouragement and his very generous support. Thank you to Mariam Habibi at the American Graduate School in Paris for sharing ideas on collective memory. Thank you to Inge Genee and the anonymous reviewers of the Canadian Journal of Netherlandic Studies; my discussion of the works of Maria Dermoût is better for their constructive suggestions. A special thank you to Julia Benschop-Plokker, Irene van Rossum and Jaap Wagenaar at Amsterdam University Press for guiding me through the process of bringing this work to publication. I am indebted to Judith Allan and Ed Hatton for their outstanding editing. I am very grateful to Esther Captain of KITLV in Leiden and Nicole Immler of the University of Humanistic Studies in Utrecht; they both read the entire manuscript and their perceptive suggestions helped to make it a better work. It goes without saying that any remaining errors of fact or misinterpretations are my sole responsibility.

Thank you to the staff, librarians and archivists at the Royal Netherlands Institute of Southeast Asian and Caribbean Studies (KITLV) in Leiden, the NIOD Institute for War, Holocaust and Genocide Studies in Amsterdam, the Eye Film Institute in Amsterdam and the Institute for Sound and Vision in Hilversum. The digitalized historical collection of newspapers at the Royal Library in The Hague, known as Delpher, was a godsend to me, while working remotely in Switzerland. A special thanks to Anja Doolan for being my secret library assistant at the University of Amsterdam. I am grateful to Eilís Doolan, who did most of the proofreading, and Esther de Vries, who 
checked the footnotes. Thanks to Jutta Pfleger and Vera Lutzke for helping with the German summaries in my original thesis.

My numerous research trips to the Netherlands were made extra pleasant by the fact that I was always provided with a roof over my head by friends. Thank you to Carolien van Tilburg and Eric van Kooij for supplying me with a room in their home in The Hague. I am hugely grateful to Elaine Flynn and Julf Helsingius who, on many occasions, gave me a warm room of my own in their beautiful house on the Prinsengracht in Amsterdam.

I ask my close friends Tony Keys and Joe Amato for forgiveness for boring them with my many meandering narratives on my topic - thank you for bearing with me all these years! Thank you to Padraig Rooney for his friendship and countless conversations on literature and writing. I thank my late friend Bill Hovey for reminding me that education ought to include the contemplation of the awe, wonder and mystery of the universe. I want to thank my sisters, Ann and Carmel, and my brothers, Tony and Daithi, for their support. Friends and family in the Netherlands and Belgium who always showed an active curiosity in what I was doing and sometimes suggested new avenues of inquiry include D'Laine Camp, Rob van der Hoeven, Danny de Vries, Eliz Buurman, Tom Teisman, Simon van der Goot, Adrie de Jong, Klaas Drenth and Renée Bolhuis. Donna de Vries-Hermansader and my mother, Muriel Doolan, always supported me, but alas neither lived to see the finished work. Most importantly, I have been blessed with a wonderfully supportive family. I am a man rich in daughters; thank you, Anja, Eilís and Aoife. Although now a university student in Amsterdam, I don't think the youngest, Aoife, even remembers a time before "Papa's PhD."

There is one very special person without whom it would have been entirely impossible for me to complete this project. Everyone who knows her is aware of how intelligent, warm and selfless Esther de Vries is. However, only she and I fully understand the debt that I owe her. For the past decade, I worked on this book during holidays and weekends. In that time, parents have passed away, our children have grown to adulthood and left home and we have reached a new phase of our lives. Yet, Esther never wavered in her support and her love. Meeting Esther is the best thing that ever happened to me and I dedicate this book to her. Thank you Esther.

Paul M.M. Doolan 


\title{
Introduction
}

\begin{abstract}
In this introduction, I explain how, during five years of studying history in the Netherlands in the mid-1980s, it puzzled me that we never studied the decolonization of the Dutch East Indies. The subject was reported in the news, but indifference seemed to dominate within the university. This has led me to the question, How has the decolonization of the former Dutch East Indies during the period from 1945 to 1949 been represented in Dutch culture? My aim is to map out the process by which a collective memory of the war of decolonization was constructed among the Dutch during the $5^{0}$ years after the declaration of independence in Indonesia (1945-1995). Using a variety of theoretical frames, I apply new readings to memories of decolonization that have been mediated in literature, memoirs, historical works, journalism, radio and television documentaries and film. This will reveal the means by which decolonization came to be (un)remembered.
\end{abstract}

Keywords: decolonization, Dutch East Indies, collective memory, unremembering

If truth be told, I was born twice. The first time, when my mother gave birth to me on a February night in late 1950s Ireland. The second, when I disembarked from a ship in mainland Europe, aged eighteen. Crooked roads eventually led me to the Netherlands in the late 1970s. It seemed to me then that all Dutch people were welcoming and warm and I delighted in their open and liberal culture. I felt more at home in the Netherlands than I had ever felt before.

In the early 1980s, I started my university studies. From the inspiring lectures of Professor M.A. Wes on Greek and Roman antiquity, to intriguing seminars on the philosophy of history from Frank Ankersmit, I received an outstanding education during five years at the University of Groningen, for which I will always be grateful. I made friendships then that have lasted a lifetime.

Doolan, P.M.M., Collective Memory and the Dutch East Indies. Unremembering Decolonization. Amsterdam: Amsterdam University Press 2021 DOI: $10.5117 / 9789463728744$ INTRO 
Most, if not all of my friends, were progressive thinkers and activists. We protested against government tyranny; we occupied the Ministry of Education as well as the university headquarters; we went from house to house collecting signatures against the placing of American cruise missiles on Dutch soil. Conversations often revolved around the liberation movements in El Salvador and Nicaragua. Sometimes, but rarely, the conversation touched upon Dutch colonial history. "Ah, Indonesia, we did terrible things there." Yes, but what things exactly? No one seemed to know the details. Even more surprising, no one seemed to care or wished to find out. Likewise, Dutch overseas history was touched upon during my studies, but without much depth.

This was even more surprising, given that Dutch colonial history was seldom out of the news. Indonesia, the former Dutch East Indies, had gained independence from the Dutch, but only after a war of liberation - or, as it was euphemistically known among the Dutch, "police actions" - that had lasted from 1945 to 1949. During my study in the mid-1980s, controversies regarding the war of decolonization regularly appeared in the newspapers. Yet my friends, most of them budding historians, seemed uninterested. I was baffled by the stories in the newspapers. When I asked my friends, all I heard was the refrain: "We did terrible things," followed by something like, "Those bloody veterans." I got the distinct impression that the military veterans or "Old Warriors" as they are called in Dutch, were a most unpleasant group of people, varying from disgruntled archconservatives to narrow-minded right-wing thugs. No doubt, the sort of people who opposed the Sandinistas in Nicaragua and supported the importation of cruise missiles into Europe. Years later, I realized some veterans had risked their lives fighting fascism during the German occupation of the Netherlands (1940-1945). Most had been between 19 and 21 years old and had been drafted into a new army and shipped to Indonesia to fight a counterinsurgency war that the Dutch public supported. Some were my friends' dads or granddads.

Clearly, this was an episode in recent Dutch history that most people seemed to want to ignore, even future historians. What explained the indifference of my friends? What explained why this war, involving the largest mobilization of military manpower in all of Dutch history, could be ignored during my lessons at university? What explained the discrepancy between its frenzied appearance, disappearance and reappearance in public media, and it being rarely mentioned in academia? These questions remained with me.

Eventually I moved away from my adopted homeland. Despite the passing of time, and from a distance, I noted that the Indonesian War of Independence remained a wound in Dutch public life that wouldn't go away. With 
some frequency, at certain points in time, the experience of 1945-1949 would be re-remembered, only to be unremembered again, like the sediment that arises when a bottle of liquid gets shaken and floats near the surface briefly, until gravity forces it silently to the bottom of the stilled liquid. There the sediment remains, almost out of sight, until memory stirs it again.

The question that I attempt to answer in this book is, How has the decolonization of the former Dutch East Indies during the period from 1945 to 1949 been represented in Dutch culture? The focus is on the $5^{\circ}$ years between the Indonesian declaration of independence in August 1945 and the anniversary of that declaration in 1995. The emphasis is on the public discourse regarding decolonization, conducted partly by means of academic historiography, but also in popular culture by means of, for instance, literature and film. It is in these mediated representations that we see collective memory being shaped and contested. My aim is to map out the process by which a collective memory of the war of decolonization was constructed among the Dutch and uncover the various representations that led to this collective memory being contested. Perhaps, in doing so, I will reveal the reasons for the indifference of my friends that puzzled me all those years ago.

A word on methodology. An attempt to map out 50 years of constructing representations of decolonization inevitably involves making a selection of sources. Some sources that I have selected for analysis will surprise no one familiar with the topic. Haasse's novella Oeroeg and Hylkema's film of the same name, Hueting's interview televised on the programme Achter het Nieuws and the subsequent parliamentary inquiry report, the historical works of De Kadt and Loe de Jong - these are obvious choices. However, others may seem less obvious. I decided to include works from some of the giants within the canon of Indische literature, works that had, at first sight, little or anything to say about the process of decolonization. However, these authors, such as Dermoût, Robinson and Nieuwenhuys, had a huge influence, especially within the Indische community, in shaping collective memory. Hence, I set myself the task of applying a rereading of their works in order to discover if this would uncover some aspect of the process of (un)remembering decolonization. I selected a number of non-fictional and fictional works by Dutch military veterans. Until very recently, these have been all but ignored by scholars. For instance, no scholar before me has ever written a word about the writings of Ben Laurens. Yet in the 1980s, his work was popular among his fellow veterans, reinforcing the collective memory of a group that felt much maligned. I included a selection of works from former colonial officials or government authorities in order to gain 
another perspective. My selection of radio and television shows from the 1970 s, 198 os and 1990s is not exhaustive, but I hope that it is representative of what was broadcast during these decades. When considering the vertical transmission of memory from one generation to the next, I selected for analysis the postmemory novelists of the first hour, who all published their first works in 1983. In order to gain a flavour of how representations of decolonization were received, I researched press coverage of the topic and included a range of national and local newspapers and magazines.

One could say, in a general sense, that I apply a postcolonial reading to my sources. I hope that I have approached every text with a certain humility and openness, allowing the text to speak. (I use "text" in the loosest sense, to refer to written works of fiction and non-fiction as well as photographs, film, and radio and television documentaries.) Nevertheless, I believe that in a post-Saidian world, any innocent reading of colonial literature demonstrates bad faith. However, I have not felt strictly bound to any one reading method. As already mentioned, this is an interdisciplinary work and I have freely borrowed concepts and approaches from leading scholars in literary studies, film theory, philosophy, and sociology. These have helped me frame my analysis of texts. As a cultural historian, I feel like cultural anthropologists are my first cousins. Hence the ideas of Auge, Connerton, Van Gennep and Turner have been helpful in framing some of my readings. I am indebted to the late Haitian anthropologist Michel-Rolph Trouillot's gem of a book, Silencing the Past: Power and the Production of History. This eclectic approach of mine may seem jarring to some scholars, but I am glad that Derrida would approve: "The laws of reading are determined by the particular text that is being read. [...] [O]ne cannot prescribe one general method of reading."

\section{Bibliography}

Derrida, Jacques. "Deconstruction and the Other." In States of Mind: Dialogues with Contemporary Thinkers, edited by Richard Kearney, 156-176. New York: New York University Press, 1995.

Trouillot, Michel-Rolph. Silencing the Past: Power and the Production of History. Boston: Beacon Press, 1995. 


\title{
$1 \quad$ Collective Memory and Unremembering
}

\begin{abstract}
Maurice Halbwachs demonstrated that memory is shaped by social forces. I argue that collective memory is mediated in symbolic representations. National collective memory is unstable and open to revision and is a site for dispute between alternative representations. Changes in media lead to changes in collective memory. The trauma within collective memory is passed down through generations. I argue that collective memory is not a process of remembering and forgetting, but remembering and unremembering. Unremembering is a process of concealment. Literature is significant in shaping collective memory, but so too are film, memoir, public media like newspapers and television, as well as works of historical scholarship. I end this chapter with a factual summary of the Indonesian War of Independence.
\end{abstract}

Keywords: collective memory, unremembering, representation, media, Maurice Halbwachs, Indonesian War of Independence

\section{Collective Memory}

This study owes a debt to, among others, the French sociologist Maurice Halbwachs. In his seminal work on collective memory, Halbwachs argued that memories are shaped by social frames of references. Astonished that psychologists deal with memory as if it emanates from inside isolated individuals, he argued, "it is in society that they recall, recognize and localize their memories." ${ }^{\prime}$ Personal memories are shaped by the group, but the group too possesses sets of memories of which a member partakes. Collective memory, Halbwachs argued, "requires the support of a group delimited in 
space and time. [...] [T] he collective memory endures and draws strength from its base in a coherent body of peoples." ${ }^{2}$ Halbwachs suggested that the group's memory is manifested in individual memories. However, the individual who remembers does so as a group member. ${ }^{3}$ During the past couple of decades there has been a boom in collective memory studies. Within the social sciences, as well as among literary scholars and historians, many have mined the rich seam revealed by Halbwachs. This work attempts to make a modest contribution to these studies.

Although the word "memory" is a noun, to believe that memory is a thing is to succumb to a form of linguistic bewitchment. "Memory" is shorthand for the process of and result of remembering. Collective memory is the process or result of individual members of a group remembering. Consequently, collective memory contains no essence, no immutable status or transcendental being. It does not exist in some ethereal sphere waiting to be discovered. Instead, it is a mediated memory that, as Jan Assman suggests, is "stored away in symbolic form."4

Paul Ricoeur applied Freud's concepts of mourning and working through loss in order to understand the formation of collective memory. ${ }^{5}$ This work of mourning takes time. The loved object (for instance, the Dutch East Indies) no longer exists but this fact arouses opposition in which the existence of the lost object is psychically prolonged. This period is characterized by a sense of grief, which Ricoeur defines as "that sadness that has not yet completed the work of mourning." However, after the painful period of mourning, with its compulsion to repeat, in a healthy subject the period of working through can commence and a reality-tested recollection occurs. In Ricoeur's words, survivors of loss "undergo the ordeal of the difficult work of remembering." Ricoeur argues that repetition-memory "resists criticism" while recollection memory, which follows the period of mourning and has as its aim the search for the truth, "is fundamentally a critical memory." ${ }^{6}$

Collective memory is unstable, fragile and frequently a source of contention. Ricoeur writes that when "national self-love" is at risk, there will be a lack of self-criticism. ${ }^{7}$ This, as we will see, was partially the case in the Netherlands, when it came to remembering the violent decolonization of

3 Ibid., 40-48.

4 Assmann, "Communicative and Cultural Memory," 110-111.

5 Ricoeur, Memory, 69-8o.

6 Ibid., 77 .

7 Ibid., 79 . 
the Dutch East Indies. The national collective memory is open to assault. Groups or sub-groups within the nation that hold counter-memories may attempt to contest the accepted narrative or try to force themselves into the national discourse. Within the nation, the orderliness and seeming unity implied by the term "collective memory" becomes a site of dispute when alternative representations surface and gain a following. In the Dutch nation after decolonization, collective memory became a site of contestation among specific sub-groups - military veterans, repatriated colonial minorities and professional historians.

Jeffrey Olick argues that remembering consists of a variety of practises and he notes three ways in which collective remembering changes. ${ }^{8}$ Firstly, an instrumental approach, when an image of the past is changed or maintained because of the deliberate efforts of social actors. Secondly, coherence - when images of the past change due to how well they fit into a culture that is itself changing or remaining the same. Thirdly, images of the past change due to changes in the media or institutions that encode the images. To borrow Astrid Erll's phrase: "the medium is the memory."

Edward Said has written that "history cannot be swept clean like a blackboard."10 Although we like to think of ourselves as free agents, individuals are bound by a horizon that is greatly determined by elements from the past. We are born into society and thrown into an ocean of memories. Our identity is forged within a family, nation state, class, language and gender, none of which we have chosen. We are initiated into the memories of our social group as soon as we start learning language. Before we are conscious of it, mediated representations of the past abound, helping to form our identity within various collectives or groups - from the family to the nation state. As Marianne Hirsch argues, memories of traumatic experiences of one generation can cast a long shadow over the inherited memories of the next generation, leading to the working through of postmemories of events not directly experienced. ${ }^{11}$ Thus, as we shall see, the scars and trauma of Dutch citizens who experienced the Indonesian War of Independence first-hand were sometimes passed on to a postmemory generation who inherited a loss of which they themselves had had no direct experience. 


\section{Collective Unremembering}

One cannot discuss memory without looking at the reverse - forgetting. Jan Assmann makes the point that forgetting contributes to forming a collective identity. ${ }^{12}$ Benedict Anderson argued that collective remembering always includes collective forgetting, what he calls "remember/forget." Erll claims that "forgetting is the rule and remembering the exception." Aleida Assmann and Paul Connerton both suggest that there are distinct social forms of forgetting. ${ }^{15}$

However, people speak too lightly about how memory comes to be erased in society, as if there is no middle ground between remembering and forgetting. As long as society has surviving individuals who experienced a traumatic event, the event is not forgotten. Survivors may remain silent, and the society itself seemingly ignores the memory of the event, yet the survivors bear the memory in their scars and gestures, their silences and inarticulate utterances. Indeed the silence is a mark of the presence of traumatic memory and such silences are traces of the event, not quite forgotten. Even when the survivors are all deceased, their experiences that have been hidden or occluded continue to live on among the next generation who have witnessed the scars, silences and pain of the first generation. Thus, memory may remain unrepresented or partially hidden, but not erased, not forgotten.

Like Ann Laura Stoler, I maintain that talk about "forgetting" is imprecise. Stoler argues that "forgetting and amnesia are more than misleading terms" given that in colonial histories, "very little of these histories has been or is actually forgotten. ${ }^{16}$ Individuals, not societies, may experience amnesia. Forgetting needs to be preceded by remembering; you cannot forget what you never knew. We cannot speak of a society forgetting, when individuals have never remembered in the first place. On the one hand, members of Dutch society knew nothing about decolonization, or had only the haziest of notions. Consequently, they could not forget it. On the other hand, those who experienced the trauma of decolonization did remember decolonization. We cannot speak of a society forgetting, when some individuals still remember. Being silent, and forgetting, are not necessarily the same thing. If a society is

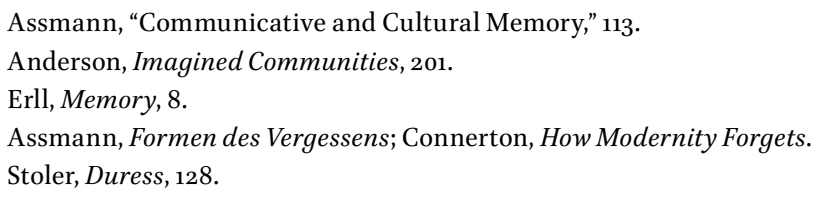


silent about an episode in its history, it does not mean the episode has been forgotten. On the contrary, silence can hold memory, even when hiding it.

Stoler replaced "forgetting" and "amnesia" with a new term: "Aphasia is a dismembering, a difficulty in speaking, a difficulty in generating a vocabulary that associates words and concepts to appropriate things. ${ }^{17}$ The term avoids the pitfalls of "forgetting" and is now widely used by postcolonial scholars. Nevertheless, I find the term problematic. "Aphasia" is a medical term and describes an abnormal condition, while, as we have seen, most scholars believe that "forgetting" is a normal state of affairs for societies. Furthermore, in its current usage there seems be an imprecise slippage between "aphasia" and "dysphasia." Frequently, the meanings of both, which are distinct though closely related terms in the medical world, seem to converge into one in the works of social scientists. Finally, "aphasia" describes a state of mind while "forgetting" is an action. In other words, replacing an adjective with a noun does an injustice to reality.

In this book I have chosen to use the term, "unremembered" or "unremembering." Etymologically, "remember" derives via the Latin memoria from the Old French remembrer. However, some have drawn attention to the close relationship between "remembering" and "dismembering." ${ }^{.18}$ We refer to the different parts of the body as "members." To re-member implies that we recall the body with all its members attached. To dismember a body means to separate or tear apart its members. When it comes to doing history, historians continuously tear the pieces apart. Although time flows in one seamless duration, we dismember it, breaking the flow by means of periodization. To remember the past when doing history, we first dismember it.

One segment or member of Dutch history is the decade 1940-1949, which could be labelled as "The Nation at War." This period was dismembered into four: the Netherlands under German occupation (1940-1945); the Dutch East Indies under Japanese rule (1942-1945); the Netherlands under reconstruction (1945-1949); the Dutch East Indies during decolonization (1945-1949). One could argue that some members or pieces have more right to prominence than others. However, problems arise when one member achieves such prominence in the collective memory that the others disappear almost completely.

With such a dismemberment of the nation's historical narrative, it became easy to disremember - with each period being remembered in a different way, by different groups. With the perceived need to maintain a national 
unity, one member - the suffering of the Dutch people under the Nazi occupation - came to dominate the remembering of the entire period, blinding one to the possibility of other memories. The dismemberment of the past led to a process of disremembering resulting in one member especially - the Dutch East Indies during decolonization (1945-1949) - becoming unremembered. Unremembered in the sense of not entirely forgotten but placed in cold storage, awaiting the trigger that would result in involuntarily rememberings (or re-rememberings). Unremembered to the extent that it was concealed from the population who never remembered. In this way, what had been a public issue in the years from 1945 to 1949 could all but disappear from public and academic discourses, although remembering survived among individuals who had been active participants and this remembering was passed on, vertically, to their progeny.

\section{Historical Representation}

Paul Connerton argues that whatever is written down demonstrates "a will to be remembered." 19 Texts transmit memory horizontally (across a generation) and vertically (to later generations). Historian's textual representations lean towards the scholarly, written essay. This offers one specific set of vantage points from which to view the past. Novelists, artists and film-makers offer alternative representations of a past reality. These representations contribute to the construction, distribution and maintenance of a mediated collective memory. Consequently, when analysing the construction of collective memory, historiographical works earn no special respect. While academic historical writing often forms the basis upon which popular works are built, it is in fictional literature, film and television that historical representations often profoundly impact public perceptions.

Literature is a major stabilizer of collective memory and through literature, memory takes on a material form and its power of transmission increases regardless of time and space. ${ }^{20}$ For a large part of the twentieth century, the novel was the significant vehicle for representing collective memory. The novel's vivid representational quality persuades readers that they are gaining an insight into the past as it was. In her attempt to represent the past, the novelist invokes the smell and feel of the past, offers multiple perspectives and voices, includes dialogues and interior monologues, real 
historical personages and fictional characters, as well as thick descriptions of place. Indeed, the shape of the novel mimics the working of memory. Dutch sociologists Lily Clerkx and Wim Wertheim wrote a study of life in a colonial settlement in Sumatra based on an analysis of a handful of novels. They justified their project by arguing that novels can be more realistic than other historical data when it comes to learning about the daily habits, attitudes and interactions among the Dutch colonials. ${ }^{21}$

Such an assertion is not defended in the present study. However, I do maintain that the novel played a significant role in shaping the Dutch collective memory of the colonial past. Therefore, representations of decolonization in the novel must be examined. Pamela Pattynama argues that "the Netherlands has always gained knowledge of the Dutch East Indies mainly through literature."22 Nevertheless, from the 196os onward other technologies began to play a significant role in the mediation of collective memory. Television and cinema contributed increasingly to the visualization of history and the remembering of the recent past. Radio too played an increasing role.

Said reminds us that it is representations that circulate within cultural discourse and these have purposes that reflect a "specific historical, intellectual, and even economic setting."23 The individual author or historian is influenced by a specific cultural archive that leads to a "structure of attitude and reference." ${ }^{\prime 24}$ Objectivity is the mask that often disguises power. Frank Ankersmit argues that representations of the past are substitutes for the past itself. The absence of the past makes representations necessary. A historical representation becomes "a textual substitute for the actual, but absent past." ${ }^{25}$ However, no representation, whether it be a scholarly monologue, a memoir, a historical novel, a documentary or a film, offers a substitute for the entire past. Texts and films offer representations of an aspect of the past. Some aspects may be more worthy of attention than others. The present study will reveal a concern among Dutch historians with creating representations of the diplomatic aspects of the past, while ignoring other aspects, such as the gory act of killing. On the other hand, some veterans of the conflict offer representations that focus almost entirely on the brutality of warfare. I argue that it was a failure of the Dutch historical profession 
that historians offered representations of a war in which warfare remained absent, the equivalent of a representation of a bullfight with the bull missing.

\section{A Short Summary of Decolonization in the Dutch East Indies}

German troops in occupied Holland surrendered in May 1945. However, the Dutch East Indies remained under foreign occupation. Since the successful Japanese invasion of the Dutch East Indies in 1942, the entire white Dutch population, so-called totoks, and a minority of the Dutch population of mixed-blood, so-called Indos, were incarcerated by the Japanese in camps. Consequently, it seemed urgent for the Dutch to raise an army in order to help the Allies defeat the Japanese. Many Dutchmen felt duty bound to continue the struggle against fascism and immediately signed up for service against the Japanese. By the time these men arrived in the Asian theatre, the Japanese had already been defeated and World War Two had ended.

The abruptness of Japan's defeat meant Japanese forces still controlled almost all of Indonesia. The Netherlands-Indies government in exile remained in Australia when the Japanese announced their surrender on 15 August. That same day the Allied Forces decided that all of Indonesia would be placed under the British command of Lord Mountbatten. Mountbatten was given the mission of disarming the Japanese and ensuring the safety and evacuation of tens of thousands of Western prisoners as well as the task of implementing a military occupation of this enormous area. ${ }^{26}$ For the Dutch prisoners in the Japanese prison camps, this proved to be liberation without actual release. Most Dutch in the former colony believed they could pick up their lives from where they left off in 1942. ${ }^{27}$ The Dutch believed that Indonesian nationalist leaders had little or no support among the native population, and had kept the main leaders, like Sukarno and Hatta, imprisoned since the early 1930 s. $^{28}$ These leaders had worked with the Japanese and two days after the Japanese surrendered, Sukarno and Hatta proclaimed an independent Republic of Indonesia.

The months that followed, the so-called Bersiap period, were chaotic and violent. With the absence of a strong central power, Indonesian nationalist youths, known as the pemuda, attacked anyone associated with Dutch rule. The totoks risked their lives if they ventured outside their prison camps. 
Their former guards, the Japanese soldiers, were now their protectors. Indos who remained outside the camps, found themselves easy prey. Men, women and children, usually Indos or Chinese, were slaughtered by the pemudas. During this period, around 3,500 Dutch citizens were killed. ${ }^{29}$

With nearly all members of the Dutch colonial army scattered across Japanese prisoner of war camps in various parts of Asia, and any newly raised Dutch army not yet ready for action, it was impossible for Dutch authorities to exert control. It fell to the British to maintain order. By 1946, the British, at a cost of a high number of casualties, especially among Indonesians, had pacified limited areas of Java and handed control back to the Dutch. Large areas of Java and Sumatra remained under the control of Indonesian nationalists. For the new Dutch army, the mandate had shifted from defeating the Japanese to protecting Dutch interests from Indonesian nationalists. Eventually the Dutch would use 150,000 conscripts in this army. ${ }^{30}$

Lieutenant Governor-General of the Dutch East Indies Hubertus van Mook favoured a negotiated settlement with moderate Indonesian nationalists, though ultimate authority lay with the government in The Hague. In October 1945, and against the express wishes of his government in The Hague, Van Mook had met with Sukarno. ${ }^{31}$ In April 1946, discussions took place in the Netherlands between Dutch leaders and representatives of the Indonesian nationalist government at the Hoge Veluwe Conference. These were characterized by an atmosphere of distrust and a peaceful resolution seemed unlikely. $3^{2}$ In the summer of 1946 , the Netherlands acquired a new coalition government of the Labour Party and Catholic People's Party. Labour wanted to build a social welfare state and the Catholics agreed to cooperate, but insisted that retaining the East Indies was economically essential. ${ }^{33}$ The new cabinet dispatched a high-powered commission to Indonesia to investigate the situation. The commission recommended that military conflict be avoided through negotiation. ${ }^{34}$ In November 1946, both sides signed the Linggadjati Agreement, by which the Dutch recognized the republic's authority over a limited area and both sides agreed to form a federal United States of Indonesia under the Dutch monarchy by 1949. Only a minority of both sides welcomed the agreement; the violence did not cease.

Ibid., 100.

30 Van Doorn and Hendrix, Ontsporing, 295 .

31 "Notulen van de vergadering van de ministers op 1 nov. 1945," (Minutes of the Cabinet Meeting on 1 Nov. 1945), in Wal et al., Officiële Bescheiden, vol. 1, 504-506.

32 Van Mook, Indonesië, 131.

33 Van der Liempt, Nederland Valt Aan, 17-18.

34 Ibid., 18-19. 
In the Netherlands, the government avoided collapse only after unilaterally applying a number of additions to the agreement without consulting the Indonesians; on the Indonesian side, nationalist military attacks on Dutch troops increased..$^{35}$ In July 1947, citing infringements of the Linggadjati Agreement, the Dutch began the first of two military offensives, which they called "police actions." The signing of the Renville Agreement in January 1948, briefly led to renewed Dutch hope that the two sides were close to creating a Netherlands-Indonesia Union under Dutch leadership. ${ }^{36}$

However, by the year's end the relationship between the two sides had deteriorated again and in December 1948 the Dutch launched their second "police action," capturing the republican capital Yogajakarta and most of the republic's leadership. The Dutch were reprimanded by the United Nations and a Security Council resolution of 28 January 1949 demanded an immediate ceasefire, the release of political prisoners, the reestablishment of the republican government in Yogajakarta and the beginning of new talks with the assistance of the United Nations that should lead to Indonesian independence by no later than July 1950. ${ }^{37}$ This pushed the Dutch into a final round of negotiations. The Dutch-Indonesian Round Table Conference took place between August and November 1949 in The Hague and the Netherlands recognized the independence of the United States of Indonesia on 27 December 1949, while retaining control over Dutch New Guinea.

\section{Bibliography}

Anderson, Benedict. Imagined Communities: Reflections on the Origin and Spread of Nationalism. Rev. extended ed. London and New York: Verso, 1991.

Ankersmit, Frank. Meaning, Truth and Reference in Historical Representation. Ithaca NY: Cornell University Press, 2012.

Assmann, Aleida. Cultural Memory and Western Civilization: Functions, Media, Archives. New York: Cambridge University Press, 2011.

Assmann, Aleida. Formen des Vergessens. Göttingen: Wallstein Verlag, 2017.

36 De Jong, Avondschot, 53-54; "Voorzitter van de Nederlands onderhandelingsdelegatie (Abdulkadair Widjojoatmodjo) aan commissie van goedediensten, 19 januari 1948," (Chairman of the Dutch Negotiations Delegation (Abdulkadair Widjojoatmodjo) to the Commission of Good Services, 19 January 1948) in Wal et al., Officiële Bescheiden, vol. 12, 565-567.

37 De Jong, Avondschot, 370-371. 
Assmann, Jan. "Communicative and Cultural Memory." In Cultural Memory Studies: An International and Interdisciplinary Handbook, edited by Astid Erll and Ansgar Nünning, 109-118. Berlin: Walter de Gruyter, 2008.

Clerkx, Lily E. and Wim F. Wertheim. Living in Deli: Its Society as Imaged in Colonial fiction. Amsterdam: VU University Press, 1991.

Connerton, Paul. How Modernity Forgets. Cambridge: Cambridge University Press, 2009.

Connerton, Paul. How Societies Remember. Cambridge: Cambridge University Press, 1996.

Derrida, Jacques. “The Parergon.” Translated by Craig Owens. October 9 (Summer 1979): 26 .

Derrida, Jacques. “Time Is Out of Joint.” In Deconstruction Is/In America, edited by Anselm Haverkamp, 14-38. New York: New York University Press, 1995.

Doel, Henk W. van den. Afscheid van Indië: de valvan het Nederlandse imperium in Azië. Amsterdam: Prometheus, 2000.

Doorn, Jacques A.A. van. De laatste eeuw van Indië: Ontwikkeling en ondergang van een koloniaal project. Zutphen: Walburg Pers, 1994.

Doorn, Jacques A.A. van and Wim J. Hendrix. Ontsporing van geweld: over het Nederlands/Indisch/Indonesisch conflict. $4^{\text {th }}$ ed. Zutphen: Walburg Pers, 2012 [1 ${ }^{\text {st }}$ ed., Rotterdam: Universitaire Pers Rotterdam, 1970].

Erll, Astrid. Memory in Culture. Basingstoke: Palgrave Macmillan, 2011.

Halbwachs, Maurice. On Collective Memory. Edited and translated by Lewis A. Coser. Chicago and London: University of Chicago Press, 1992 [1950].

Hirsch, Marianne. The Generation of Postmemory: Writing and Visual Culture after the Holocaust. New York: Columbia University Press, 2012.

Jong, Joop J. P. de. Avondschot: Hoe Nederland zich terugtrok uit zijn aziatisch imperium. Amsterdam: Boom, 2011.

Liempt, Ad van der. Nederland Valt aan: Op weg naar oorlog met Indonesië 1947. Amsterdam: Balans, 2012.

Mook, Hubertus J. van. Indonesië, Nederland en de Wereld. Amsterdam: De Bezige Bij, 1949 .

Olick, Jeffrey K. The Politics of Regret: On Collective Memory and Historical Responsibility. Oxon: Routledge, 2007.

Pattynama, Pamela. "Laat mij voor een keer schaamteloos terug verlangen ...': De herinneringsknoop van Indische nostalgie." Indische Letteren 23, no. 2 (2008): 50-62.

Ricoeur, Paul. Memory, History, Forgetting. Translated by Kathleen Blamey and David Pellaur. Chicago and London: University of Chicago Press, 2004.

Said, Edward W. Culture and Imperialism. London: Vintage, 1994.

Said, Edward W. Orientalism. London: Penguin Books, 2003 [1978]. 
Stoler, Ann Laura. Duress: Imperial Durabilities in Our Times. Durham NC: Duke University Press, 2016.

Wal, Simon L. van der, Pieter J. Drooglever and Mieke J.B. Schouten. Officiële Bescheiden betreffende de Nederlands-Indonesische Betrekkingen 1945-1950, 20 vols. The Hague: Instituut voor Nederlandse Geschiedenis, 1971-1996. 


\title{
2 Representations during the War
}

\begin{abstract}
During the Indonesian War of Independence (1945-1949) Dutch national media collaborated with the authorities in providing a sanitized representation of the conflict. The public was complicit in this early unremembering. Some left-wing media carried reports of Dutch atrocities. Joris Ivens' documentary Indonesia Calling (1946) represented the conflict as one of international liberation which contested colonialism, but was viewed by few members of the Dutch public. Hella Haasse's novel Oeroeg (1948) came to be widely read as a representation of the irreconcilability of East and West. In early historiography, Van Mook offered the enlightened colonial view that the Dutch mission had been sabotaged by outsiders. De Kadt's thesis was that Dutch smugness had brought about the violent conflict.
\end{abstract}

Keywords: Joris Ivens, Hella Haasse, Indonesia Calling, Oeroeg, unremembering, decolonization

\section{The Press}

Paul Virilio argues that while there is no war without representation, it is only in industrialized warfare that representation outstrips the facts. ${ }^{1}$ Lieutenant-General S.H. Spoor, commander-in-chief of Dutch forces during the Indonesian War of Independence, was aware that this conflict would be fought by means of representations in the public arena as well as by combat on the battlefield. Consequently, he set up a military information service with headquarters in Batavia. ${ }^{2}$ The Dienst voor Legercontacten (DLC, Army Contact Service) produced "military magazines, bulletins, press releases, radio shows, photos and films,"3 ensuring that the Dutch public received a

1 Virilio, War and Cinema, 1-8.

2 De Moor, Generaal Spoor, 203-204; Zweers, De gecensureerde oorlog, 29-30.

3 Zweers, De gecensureerde oorlog, 40.

Doolan, P.M.M., Collective Memory and the Dutch East Indies. Unremembering Decolonization. Amsterdam: Amsterdam University Press 2021 DOI: 10.5117/9789463728744_CHO2 
sanitized version of the war that, for the most part, lacked any representation of actual warfare. Indeed, Louis Zweers goes as far as to say that the army and navy information services "were virtually absolute rulers in the area of military information and propaganda." ${ }^{\text {Th }}$ Thus, the war that was represented was a fiction, ensuring the unremembering that would follow.

\section{Film and Photography}

Multifilm Batavia may have had the appearance of a private company, but as Gerda Jansen Hendriks shows, it was government controlled. ${ }^{5}$ She lists dozens of propaganda films that the Rijksvoorlichtingsdienst (RVD, Government Information Service) commissioned from Multifilm Batavia during the war of decolonization. ${ }^{6}$ An important source of public information in the Netherlands regarding world events came from Polygoon news journals shown in cinemas. The Polygoon leadership collaborated with the Dutch military authorities in creating propaganda, the chairman of its news commission admitting, "we are in principle willing to make propaganda for the army in the Indies, as long as it is good quality propaganda." ${ }^{77}$ Members of its board included representatives from the Ministry of Education, Arts and Sciences as well as the RVD. Jansen Hendriks points out that Polygoon enjoyed an advantage over potential competitors as the company had a monopoly in presenting news features in nearly every cinema in the Netherlands. Because the company did not themselves have camera crews in the Indies, they relied on footage supplied to them by the authorities. ${ }^{8}$ Much of this was produced by Multifilm Batavia.

Consequently, it is not surprising that the newsreels showed carefully staged scenes and never real fighting. These staged scenes presented the Dutch public with a picture of an army that came in peace. Right from the beginning, this is a war that, in its representation, is characterized by the absence of the act of killing. Scenes of soldiers setting off for the kampongs (villages) with their bags of medicine for the villagers, the Red Cross prominently displayed, were frequent. Also popular were shots of troops dispersing food aid, mending roads and bridges, and carrying out 
patrols in order to ensure the safety of the villagers. There are no scenes of burning village houses or aerial bombardment.

Take, for instance, the two-part film Brengers van Recht en Veiligheid (Bringers of justice and security). In the first part, we are told that the "terrorists" treat their compatriots brutally. But the Dutch soldier serves the people. Local children are "best mates" of the soldiers, and we see them, as well as their elders, volunteering to help the soldiers with household tasks. We see soldiers on patrol - they crouch, break suddenly into a run, leap to the ground and open fire at an unseen enemy. These scenes clearly are staged. The film shows Dutch soldiers exchanging language lessons with liberated villagers and the final scene shows Dutch soldiers and Indonesian villagers drinking from the same coconut.

The aim of Dutch military actions, we are told, is the creation of a new basis for cooperation between the Dutch and Indonesians. We see the military at their preparations: maps are studied, soldiers march and board trucks, engineers prepare materials for repairing bridges, armoured vehicles are checked, planes are sent on reconnaissance flights, telegraphists open lines of communication, divisions are moved into position and watches are synchronized. The entire sequence gives an impression of Western organization and capability. Then the troops advance. Soldiers form human chains to cross rivers, mobile telephone units maintain communication, armoured vehicles protect infantry, and villages are avoided until the enemy can be fought directly without endangering the innocent. Soldiers enter a village. A Dutch flag is hoisted. A group of villagers looks relieved. However, the essence of warfare, the act of killing, is absent. The "terrorists" are never within range of the camera's eye. Once the village is secure, life is normalized - women pound grain, make batik, villagers spin cotton. The narrator tells us that trust has been rebuilt; the basis has been laid for a new future, a new cooperation between East and West. The European army is efficient and selfless, while the people of Indonesia are docile victims of terrorists, dependent on Dutch aid.

A number of short films were made under the title Soldaat Overzee (Overseas soldier). One, broadcast in January 1948, began with a soldier looking into the camera. He says, "I am Jan. I come from the cities and villages of the Netherlands, and now I'm in the red heat of the tropics." The purpose is to represent the Dutch soldier as being an ordinary, tough but honest lad - the boy next door. A photobook of the same title was published and sold over 50,000 copies in $1947^{9}$ 
Film-makers may have believed they were serving a "noble purpose," but according to Jansen Hendriks, they were "pulling the wool over people's eyes." Most films were made on the orders of the DLC. The films mediated not so much a war but a humanitarian mission. Also popular were documentaries that linked seamlessly with films that had been produced near the beginning of the twentieth century. These picturesque films about local peoples and customs, what Said would call Orientalist, appealed to the Dutch cultural archive, in which colonialism was seen as something humanitarian and ethical. ${ }^{11}$

Some representations of the conflict were deemed not suitable for the Dutch public. In 1947, the film Linggadjati in de branding (Linggadjati burning) was released in cinemas in the Dutch East Indies. It showed some non-aggressive scenes of the Dutch military offensive. Despite mildly positive responses from viewers, Lieutenant Governor-General Van Mook decided not to release it for audiences in the metropole. It was taken out of circulation and was never broadcast in the Netherlands. ${ }^{12}$

It was next to impossible to create representations that countered the official myth of war as a humanitarian project. We will see in the following section the lengths that the authorities went to in order to occlude Joris Ivens' anti-colonial film, Indonesia Calling. Henk van Randwijk, editor of the weekly Vrij Nederland and an outspoken critic of the war, helped to produce a 20-minute long film, Oud en Nieuw in Indonesië (Old and new in Indonesia), hoping it would provide a counterweight to the official pro-war propaganda. The government Film Commission twice refused to grant it a licence for distribution, and it was never released. ${ }^{13}$

By 1949, the war had stretched on for nearly four years and most of the world, it seems, had turned against the Netherlands. After a second "police action," the DLC found it necessary to create a 40-minute documentary proving the purity of the intentions behind the actions of the military. The film, Het Vreemde Leger (The strange army), was edited and commentary was written by military photographer and correspondent Ton Schilling. It was framed like a personal travelogue by someone who had travelled along with the military forces just to give the viewer back home a personal, but honest view. Twice we are told that this is not propaganda. ${ }^{14}$

\footnotetext{
10 Jansen Hendriks, Klein and Otten, "The Final Years," 82.

11 Jansen Hendriks, "Een voorbeeldige kolonie," 274-277.

12 Ibid., 255-257.

13 Ibid., 26o-262.

14 The film credits mention it was made "in opdracht van de Dienst van Legercontacten" ("ordered by the Army Contacts Service"), Het Vreemde Leger: 2e politionele actie - Java en Sumatra, Multifilm, Java, 1949.
} 
The film is an ode to the hard-working army, composed of honest men from all ranks of society. We see the results of republican chaos in areas formerly held by the nationalist government - starving children, orphaned Eurasian children, scenes of devastated houses, churches and workplaces. Dutch soldiers work in the newly liberated zones - treating the ill, feeding the hungry, distributing clothes, working with the locals at reconstructing roads and repairing telegraph wires, accepting the weapons of republicans who turn themselves in and then training these former enemies to become a new militia under Dutch authority. We see no fighting, no war wounded, no dead bodies. We do see the funeral of a Dutch soldier. This too was in keeping with a directive of the DLC, calling for scenes of solemn burials that would remind the home front of the hardship and sacrifice of the army, yet provide comfort for family members by seeing that their boys received a respectful funeral..$^{15}$ This army, Schelling concludes, is "the strangest army that ever was." The war, we are told, is not fought to simply protect the interest of Dutch capitalists, but for a just cause. But clearly, the film had been made at a time in which voices back home questioned the war's legitimacy. One has to agree with Jansen Hendriks in wondering if journalists like Ton Schilling "still believed in their own message. ${ }^{m 6}$ At this stage in the war, many did not. Prime Minister Drees recommended that the film not be released. The film reminded him of a "four-year nightmare." ${ }^{\text {"17 }} \mathrm{By}$ mid-1949, it had become clear that the war was, for the Dutch, a lost cause.

Ever since its first use in the Crimea War (1853-1856), war photography has been used for propaganda. As Susan Sontag reminds us, for most of its history war photography has been managed and carefully staged. ${ }^{18}$ The representation of the war of decolonization in photographs in the Dutch press was consistent with the representation in propaganda films. The press in the metropole was dependent on the authorities for providing them with images of the conflict. Dutch military authorities were not going to take the risk of allowing horrifying images be published and instead implemented a carefully planned management of public perception. All photographers had to be accredited by the military authorities. ${ }^{19}$ The Marine Information Service and the DLC strictly controlled the flow of information. Only approved photographs were sent to the Netherlands, to be distributed among

7 Ibid., 311.

18 Sontag, Regarding the Pain, 42-51.

Kok, Somers and Zweers, Koloniale Oorlog, 66. 
the press, and only after photo captions had been approved in The Hague. ${ }^{20}$ A distorted representation of the conflict ensued, in which warfare did not involve killing. For instance, in 1947, army photographer Ben Huisman captured the hard reality of the war in eastern Sumatra. The photographs showed scenes of Indonesians being interrogated, stripped naked and humiliated, as well as images of dead Indonesians and burnt-out buildings. They were withheld by the DLC and not published until $1997^{21}$

Zweers argues that the main Dutch illustrated magazines collaborated in constructing a manipulated representation of the war, uncritically publishing photographs supplied by the DLC. This meant that "one-third of the population [...] had the approved image of the situation in the Dutch East Indies [...] served up to them.".22 In the daily newspapers the situation was little better, with newspapers sometimes publishing identical photographs on their front pages. ${ }^{23}$ The exceptions were the left-wing press - the communist De Waarheid and the socialist Het Parool, as well as the weeklies De Groene Amsterdammer and Vrij Nederland. However, these publications all lacked the funds to have a photographer stationed in Indonesia. ${ }^{24}$

Another source of photographic representation lay in the amateur photographs of Dutch soldiers themselves. Not every soldier could afford a camera, but the authorities actively encouraged soldiers to create photo albums. ${ }^{25}$ These photo albums have recently become an area of interest to historians, especially since the publication in a national newspaper in 2012 of two photographs of Dutch soldiers executing Indonesians - the first of their kind ever to be published. Susie Protschky has tentatively suggested, "there are numerous examples of photographs that could constitute further, explicit evidence of atrocities committed." Such images, she argues, would have circulated within a selective visual economy of, "social and professional publics. ${ }^{26}$ In other words, they were shared with carefully monitored audiences - perhaps with family members and, more likely, with fellow veterans. Their impact, on public representations of the war, was negligible. Consequently, they played little or no role in the creation of a collective memory.

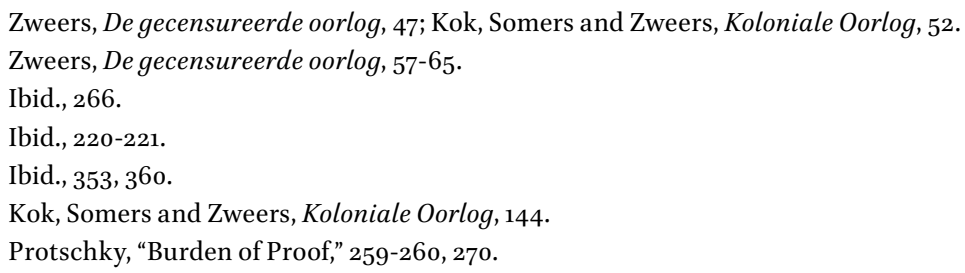




\section{Print Journalism}

The Dutch-Indies Government Information Service produced a number of newspapers, magazines and news bulletins. One such was Het Dagblad, a daily newspaper circulated free of charge. Het Dagblad promised that it would not provide propaganda, but would provide calm and truthful information. ${ }^{27}$ But for the most part the Dutch-language press represented the conflict as one of law and order with Dutch forces battling terrorism. Nadap Pieter analysed reports of three Indisch newspapers and found that all three defended the same point of view. ${ }^{28}$ Typical is the report in Het Dagblad, in which Dutch troops are welcomed by the local Indonesian population who "stood rows deep alongside the road, cheering with enthusiasm and with both thumbs up." ${ }^{29}$ Another newspaper described the Dutch army during the second "police action" as being like a vacuum cleaner "that sucks away the dirt but leaves the good behind." $3^{\circ}$ All three newspapers represented the intervention by the United Nations as "inexpert" and portrayed the Soviet Union as the real threat to world peace..$^{31}$

Journalists embedded in the army were accredited to the Ministry of War, registered as civil officers and wore military attire, while a visa requirement kept undesirables out. Journalists and photographers rarely visited war areas, remaining in the capital, Batavia, and relying on communiqués from the DLC. When journalists telephoned their stories home their conversations were listened to by army personnel. When they resorted to telegram, they had to use the army telegram service..$^{32}$ The Dutch public's acceptance of the representation of the conflict provided by the authorities to the independent press allowed the authorities to provide the public with a false image of reality. ${ }^{33}$

A prominent exception was the Amsterdam newspaper Het Parool. The newspaper had been founded by Frans Goedhart as a mouthpiece of the anti-Nazi resistance during the German occupation. Goedhart had become an influential member of the new ruling Labour Party. Having visited the nationalist leaders in Yogajakarta, using the name Pieter 't Hoen, he published the first of a series of articles arguing that the Netherlands should

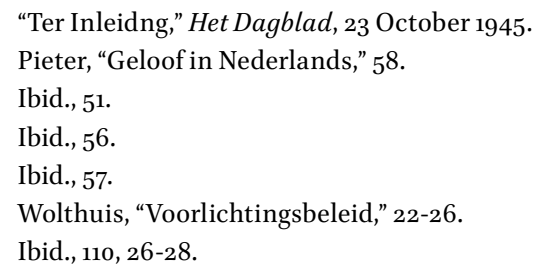


avoid military conflict and instead organize a peaceful transfer of power. ${ }^{34}$ When the Dutch launched their first so-called "police action" in July 1947, Het Parool quoted on its front page a speech of the Indonesian leader Amir Sjarifuddin, in which he accused the Dutch of launching a colonial war and warned that Indonesia was free and would never surrender. ${ }^{35}$ In an editorial, they rejected the use of the term "police action." ${ }^{36}$ However, Het Parool was read by a relatively small constituency and its anti-colonial reporting led to thousands of its readers cancelling their subscriptions. As Zweers puts it: "It seems the readers were less progressive than the editors." 37

In contrast to Het Parool, and far more typical of the majority, when the first "police action" was launched the liberal Algemeen Dagblad used the term "police action" in its main front page story and quoted from a speech from the Dutch queen. ${ }^{3}$ Lieke Hagebeuk compared how the conflict was covered in Het Parool and the pro-government, Catholic De Volkskrant. Het Parool cheered on the fact that the Dutch government entered negotiations with delegates of the Indonesian republicans in 1946, while De Volkskrant condemned this as shameful. ${ }^{39}$ De Volkskrant ignored the republican point of view while Het Parool interviewed republican delegates and permitted Indonesian Prime Minister Sjahrir to air all sorts of accusations against the Dutch. ${ }^{40}$ Het Parool referred to "Indonesia" and "Indonesian" while De Volkskrant preferred the (colonial) term "Dutch East Indies." Het Parool referred to members of the Indonesian government by their official titles but De Volkskrant put their titles, such as "minister" between inverted commas. ${ }^{41}$ When reporting on violence, Het Parool focused on Indonesian victims, often blaming Dutch troops, while in De Volkskrant it was the other way around. ${ }^{42}$

Dutch media did not provide one homogenous pro-Dutch view of the conflict. The violence unleashed in 1947 brought a mixed response, though mainly positive. But a growing group began to question the war. In late 1948, questions were asked in parliament regarding reports of the use of excessive

34 De Keizer, "Mission Impossible,"” 36o; Pieter 't Hoen, "Sjahrirs binnenlandsche moeilijkheden," Het Parool, 19 July 1946.

35 "Wij zullen nooit een andere regering erkennen," Het Parool, 22 July 1947.

36 "Politioneel," Het Parool, 22 July 1947.

37 Zweers, De gecensureerde oorlog, 198.

38 "De Politiële Actie op Jave," Algemeen Dagblad, 22 July 1947; "Koningin richt zich tot de strijdkrachten," Algemeen Dagblad, 22 July 1947.

39 Hagebeuk, "Indië verloren," 4.

40 Ibid., 34-37.

41 Ibid., 44-45.

42 Ibid., 58. 
violence by Dutch troops, and this began to dominate newspaper coverage of the conflict. In February 1949, De Groene Amsterdammer published a letter from an unidentified officer. ${ }^{43} \mathrm{He}$ wrote:

KNIL [Royal Netherlands East Indies Army] officers: [...] [D]efend with passion and conviction the assertion that, for instance, if you are shot at from a kampong [village] then this kampong should be set on fire from four sides before the inhabitants have the chance to run away. And whoever then tries to escape, $[. .$.$] shoot them with a machine gun, preferably not$ caring if these include women and children.

The officer drew a comparison to Putten, the site of one of the worst Nazi atrocities perpetrated on Dutch soil. The officer wrote of summary executions of prisoners who are "simply shot behind the head and then buried." He described the Indonesians as living under "military terror." He described the civil government as being led "by people who had been civil servants or plantation owners before the war, and they still see the Indonesian always as someone who, at the clap of your hands, will climb a palm tree to get you a coconut and is expected to treat every white as some sort of half-god."

In April, De Groene Amsterdammer published a letter from a conscripted soldier. ${ }^{44}$ He wrote that the troops were doing much good work, but agreed with every word of the previous letter, writing of the war crimes perpetrated by Dutch soldiers, the military terror and the cowardice of those afraid to speak out against the outrages. He agreed that the civil administration wanted to turn the clock back to the colonial days.

On 23 March 1949, the liberal NRC Handelsblad reported that a certain Pastor Hildering claimed that Dutch troops had attacked personnel and patients in a polyclinic in the town of Peniwen, killing ten members of a Christian church and raping three women. ${ }^{45}$ General Spoor called for an official investigation into the Peniwen affair. ${ }^{46}$ Goedhart published an article on the "cruelties and excesses," wondering if, in future years, there will be monuments in villages throughout Indonesia remembering the Dutch atrocities, just like the monuments being erected in the Netherlands

43 Anonymous, "Een officier schrijft aan zijn vrienden," De Groene Amsterdammer, 26 February 1949.

44 Anonymous, "Nog een brief uit Indonesië," De Groene Amsterdammer, 2 April 1949.

45 "Ernstige Klacht," NRC Handelsblad, 23 March 1949.

46 "General Spoor gelast onderzoek te Peniwen," Trouw, zo March 1949. 
to remember the Nazi atrocities. ${ }^{47}$ In May, newspapers reported that the investigation into the Peniwen affair had not turned up any evidence against Dutch soldiers and no further investigation would take place. ${ }^{48}$

An anti-war organization brought out a pamphlet in 1949, composed mainly of newspaper articles. It contained graphic descriptions of mass killings and torture perpetrated by Dutch soldiers. ${ }^{49}$ One writer argued that the Dutch will have to admit that there is no difference between the Dutch and the Germans, and concluded: “Isn't it time to admit that War is Genocide?" $5^{\circ}$ On the other hand, journalist Alfred van Sprang penned an account of his seven months embedded with the army. He wrote about an army that protected a terrorized population, rejecting accusations of atrocities: "Someday [the world] will have to open its eyes to reality. Then the sharp protests, the insulting words and the fierce reactions of the Security Council will be recognized as false accusations." ${ }^{11}$

In August 1949, the Round Table Conference in The Hague commenced, with the Indonesian nationalist leaders facing their former adversaries across the negotiating table. Vrij Nederland ran a long article by Henk van Randwijk. He asked, Why had the inevitable taken four years? He concluded: "Something important is taking place on Dutch soil. One of the most important things to have ever taken place and of a significance that will stretch at least as far, and maybe further, than the arrival of the Germans and the later liberation." $5^{2}$

However, the German occupation would come to dominate Dutch historical memory while the decolonization of its Asian colony would be unremembered. Almost the entire press corps, and most of the public, had acquiesced in accepting a representation of the conflict that was constructed by an official disinformation campaign. This formed the basis for further unremembering. In fact, the Dutch had experienced two Indonesian wars of decolonization. The first was a fiction, perpetrated by the military and government authorities, distributed widely by a complicit press and accepted by the majority of a compliant population. In this fictional war, the Dutch

47 Pieter't Hoen, "Gegevens voor de P.G. te Batavia: Onafhankelijk enquête is noodzaakelijk," Het Parool, 4 April 1949.

48 "Batavia rapporteert over beweerde excessen," Het Parool, 20 May 1949; "Onderzoek in de zaak Peniwen," Algemeen Dagblad, 20 May 1949.

49 Riemens, Wat gebeurt.

50 W.G. Bezemer, "het gebeuren 'te...," De Vlam, 1 October 1949.

$5^{1}$ Van Sprang, Laatste actie, 80.

52 H.M. van Randwijk, "Geen tragisch einde, maar een goed begin," Vrij Nederland, 27 August 1949 . 
had fought a huge first-aid campaign against collaborators of the Japanese but were betrayed by an ignorant international community. The second war was very real, but only known to those who experienced it - especially the tens of thousands of conscripted soldiers. This real war was one of counterinsurgency and mass violence. In the home front, it was only the small number of readers of some left-wing publications that accepted the reality of this war. This second war would be unremembered.

\section{Indonesia Calling: A Film}

By the late 1930s, Joris Ivens had built an impressive oeuvre of politically motivated documentaries. Though confessing that his early films were aesthetic, Ivens admitted that creating beautiful films was "a dead-end street" and that, eventually, "I saw that content, especially in the documentary film, had to mean social content. That social content, in a stronger situation, becomes political content, and, in an even stronger situation, becomes militant." 53 The decolonization of Indonesia was one such situation and compelled him to make one of his most militant films.

When Germany invaded the Soviet Union in June 1941, Ivens offered his services as a film-maker to the Dutch government in exile. ${ }^{54}$ On 28 September 1944, he was appointed film commissioner of the Netherlands East Indies. Charles van der Plas, Dutch delegate to the Allied Supreme Command in the Pacific and the emissary of Lieutenant Governor-General Van Mook, told Ivens that the post-war Dutch East Indies would promote "a high degree of self-determination for Indonesians in domestic affairs." ${ }^{55}$ Ivens agreed to make films shot in the combat zone and after the defeat of the Japanese, he would make educational films for the newly liberated Dutch East Indies.

Arriving in Australia in 1945, Ivens quickly discovered that many members of the Dutch East Indies government in exile had plans for the future of the Dutch East Indies that were contrary to his own. ${ }^{6}$ The situation came to a head when the Japanese surrender was followed by Sukarno and Hatta's declaration of independence. When the Dutch set sail from Australia to return to their former colony, a mutiny broke out among Indonesian seamen, followed by Australian dockworkers' refusal to load Dutch ships. By 
September, trade unionists, as well as Indian and Chinese seamen, were refusing to man the Dutch ships.

Moved by the plight of the Indonesians and by the international solidarity demonstrated by Chinese, Indian and Australian workers, Ivens quit his official Dutch government position in November 1945. In his letter of resignation, he noted that the ideals expressed in the Atlantic Charter would suggest that the Indonesians had the right to national independence. ${ }^{57} \mathrm{By}$ this stage, he had already secretly begun making Indonesia Calling. When the film was released in 1946, instead of depicting the Dutch return to their colony, and their noble mission, Ivens had represented the Indonesian struggle for independence.

Ivens represents a conflict where white and coloured work together for a common goal. David Hanan suggests Indonesia Calling breaks with the Orientalizing approach of Western film-makers towards Asians. ${ }^{8}$ Instead, as Hogenkamp puts it, Ivens' work "stresses that Indonesians are people like any other." 59 Gerda Jansen Hendriks considers the unique quality of Ivens' film to be its focus on the international solidarity between people of different creeds and colour. ${ }^{60}$ Thomas Waugh claims that Indonesia Calling is unique for being the first "post-colonial solidarity film." ${ }^{61}$

Film historian Bert Hogenkamp suggests four ways of looking at Indonesia Calling. Firstly, we can read the film as a representation of international working-class solidarity in action. Secondly, it can be viewed as a significant part of Australian trade union history. Thirdly, it can be seen as an example of how non-fiction film can promote progressive forces. Fourthly, the film can be analysed for its mythical aspects which themselves "became a force in history." ${ }^{62}$ In this fourth way, Indonesia Calling became, in Dutch society, an attempted intervention in the national collective memory. The work was a filmic pamphlet in that it did not record an event, but actually shaped what was happening. Ivens did not reconstruct an episode in the Indonesian revolution, but Indonesia Calling became an episode in the revolution.

The film premiered in Sydney, Australia, on 9 August 1946. A copy was presented to a representative of the Indonesian republican government for President Sukarno, though, as Schoots puts it, it was strictly symbolic

$5^{8}$ Hanan, "Fellow Travellers," 54.

59 Hogenkamp, "Indonesia Calling," 229.

60 Jansen Hendriks, "Bersiap,” 21.

61 Stufkens, "Joris Ivens," 31.

62 Hogenkamp, “Indonesia Calling," 230. 
because, "in reality [it was] an empty can as there were no copies." ${ }^{33}$ Waugh claims that two copies of the film circulated in republican Java, dubbed into Malay and shown to outdoor audiences, becoming "an important arm in the Indonesian resistance." ${ }^{64}$

The film had been made in secret and no credits appeared, protecting those involved. Australian authorities bowed to pressure from the Dutch government and issued an export ban, but by the end of 1946, a new Labour government was in power and, after a screening for the entire new cabinet, the export ban was lifted. In 1948, the film was due to be shown at the Locarno Film Festival in Switzerland but was withdrawn after objections by the Dutch government. In 1962, Dutch Minister for Foreign Affairs Joseph Luns refused to send a representative to the Dutch Film Days at a film festival in West Germany because of the inclusion of Indonesia Calling in the programme. ${ }^{65}$

One of the first countries to buy the film was the Soviet Union. It was shown in the USA, Great Britain and France and was hailed as an anticolonial film. However, the film had no chance of passing the Board of Film Censors in the Netherlands and Ivens did not waste his time trying. Thus, in an act of unremembering, Dutch filmgoers were denied the opportunity of viewing Indonesia Calling. Ivens left Australia in early 1947 and arrived in Holland. At a presentation at Amsterdam's Kriterion Theatre, he avoided any reference to Indonesia Calling. However, he did show the film to members of the Dutch Communist Party and an artists' group called De Kring. A number of left-wing newspapers carried articles about Ivens and the communist newspaper De Waarheid published a series of four articles in the space of two weeks, singing his praises, but none mentioned Indonesia Calling for the simple reason that its existence was still known to only a few. ${ }^{66}$

Gradually the film was mythologized, becoming a symbol, even for those who had never seen it. As Hogenkamp puts it: "being for or against the film meant being for or against the way in which the Dutch had handled their colonial past." ${ }^{67}$ By the mid-196os, Indonesia Calling had a growing following, long before it had an audience. This made it unusual in the history of the cinema. In its symbolic form, it intervened in the historical process, shaping memory and providing a site for the articulation of diametrically

63 Schoots, Living Dangerously, 207.

64 Waugh, Conscience of Cinema, 345.

65 Schoots, Living Dangerously, 207-282.

66 Ibid., 208-213.

67 Hogenkamp, “Indonesia Calling," 231. 
opposing approaches to the national past. The facticity of the film had become tangential. One's opinion of the (unseen) film signified one's position in the context of postcolonialism.

By the early 1960s, the rights and wrongs of Indonesia Calling were bound up with the fate of its maker. Many accepted the view, perpetrated by Ivens himself, that the Dutch director suffered persecution because of his telling the truth about the Dutch in Indonesia. In 1963, he wrote of Indonesia Calling:

This short film showed that a so-called police operation was in reality a fully fledged colonial war. It earned its maker eight years of exile. Nor should we forget certain retaliatory methods, like the blacklists aimed at film-makers who dared to tell the truth about their own country. ${ }^{68}$

The film's critical representation of the conflict seems to have brought about an officially sponsored harassment of the director. In the increasingly oppressive climate of the Cold War, and just months after Indonesia had achieved independence, Ivens had had his Dutch passport seized by the Dutch authorities. For a number of years he had to renew his passport every three months, so the Dutch authorities could monitor his whereabouts. ${ }^{69}$ His biographer, Hans Schoots, argues that Ivens exaggerated his persecution, but it became an accepted truth among leftist intellectuals, artists and the Dutch press that Ivens, one of the few to have dared to hold up the truth during a colonizer's war, was unwelcome and unforgiven and was persecuted by his own country. ${ }^{70}$ Eric van't Groenwout, who wrote his dissertation on Indonesia Calling, claimed that it wasn't Indonesia Calling that led to the Dutch government declaring Ivens as persona no grata, but rather, in the climate of the Cold War, it was his active communism. ${ }^{71}$ However, while his communism may have been the straw that broke the camel's back, Indonesia Calling was the ultimate provocation. In Hogenkamp's words, it was "like a red ray [sic] to a bull." ${ }^{2}$

Views on Ivens in some quarters began to soften by the late 1950s. In 1959, the Algemeen Handelsblad suggested that Ivens had lost the goodwill

68 Quoted in Delmar, Joris Ivens, 112.

69 Schoots, Living Dangerously, 228-230.

70 Ibid., 282-284.

71 Eric van't Groenwout, “Indonesia Calling (1945): Het ongepubliceerde dossier van de Binnenlandse Veligheidsdienst over Cineast Joris Ivens," Vrij Nederland, 23 May 1987.

72 Hogenkamp, “A Special Relationship," 188. 
of the authorities for twelve years because he had made Indonesia Calling, but the article quoted Ivens as saying: "I have always been a Dutchman; I could never take a position against my compatriots." ${ }^{73}$ By the early 1960 , it had become received opinion among most journalists that Indonesia Calling had been not an anti-Dutch film, but an anti-colonial film. ${ }^{74}$ In 1963, Het Parool declared that it was time to recognize that, regarding the "infamous affair," Ivens had been correct.75

In 1964, the Dutch Film Museum and the Amsterdam Film Academy decided to organize a public celebration of the director's $65^{\text {th }}$ birthday. He returned to the Netherlands for a weeklong festival in his honour. ${ }^{7} \mathrm{On}$ his $70^{\text {th }}$ birthday, there were more celebrations and the Dutch Minister of Culture, Recreation and Social Work had a number of meetings with Ivens and offered to finance a new documentary. A small group of adversaries in The Hague, led by Joseph Luns, still fought a rearguard action against the director. ${ }^{77}$ By the time of his $80^{\text {th }}$ birthday, Ivens was feted worldwide. Long revered by officials in the USSR, East Germany and Cuba, he had been welcomed to North Vietnam by Ho Chi Minh and to the People's Republic of China by Mao Zedong and Zhou Enlai. But in Western Europe his contributions to film had been recognized and honoured as well. Spain's government awarded him a gold medal for his services to art, in France he was made a Commander of the Legion of Honour and in Italy, he was made a Knight Commander of the Order of Merit..$^{7}$ In his home country there now was a near consensus that Indonesia Calling had led to his unjust persecution. During the celebrations for his $80^{\text {th }}$ birthday in 1978, the Dutch Minister for Overseas Development presented Ivens with an award for his services to the promotion of development issues. ${ }^{79} \mathrm{Het}$ Parool published a long interview with the film-maker and claimed that the Dutch government had attacked the man, rather than the film. ${ }^{80}$ Two years later the Algemeen Dagblad was singing his praises, giving him the nickname "The Flying Dutchman," who had journeyed on an "ideological

73 “Joris Ivens, de Nederlander," Algemeen Handelsblad, 4 July 1959.

74 Hans Saltink, "Joris Ivens, bondig filmer van het wereldgebeuren," Het Vaderland, 5 January 1963 .

75 C.B. Doolaard, "Nederland te schuw jegens Joris Ivens," Het Parool, 14 December 1963.

76 Schoots, Living Dangerously, 282.

77 Ibid., 314 .

78 Ibid., 354 .

79 Ibid., 336 .

80 Jan Bart Klaster, “De Camera als Wapen,” Het Parool, 18 November 1978. 
Odyssey." ${ }^{81}$ Yet, in 1982 , he was still willing to tell a journalist that he was "a son of the revolution of $1917 . " 82$

In 1985, the jury of the Dutch Film Days in Utrecht awarded Ivens a Golden Calf. The jury explained: "As long as film and television have existed, bureaucracies, ruling cliques and politicians have tried to control the medium. Joris Ivens has resisted this pressure all his life. He has suffered outrageous libel and deep humiliations for filming what he saw." ${ }^{83}$ The reference to Indonesia Calling was clear. Ivens, who lived in Paris, requested that the government minister should travel to Paris and present him with the award. A minister was dispatched to Paris. The newspaper De Volkskrant warned: "Ivens will not accept anything from a representative of the government unless told in so many words that Holland has been unjust to its greatest director for almost 40 years." ${ }^{84}$

What was being referred to was the 40 years since Indonesia Calling. At a ceremony at the French-Dutch Institute in Paris, Ivens received the award. In his speech, the minister said, "Shortly after the war, your support for Indonesia's right to self-determination and your film Indonesia Calling brought you into conflict with the Dutch government. [...] I can now say that history has come down more on your side than on the side of your adversaries." ${ }^{85}$ Even the Algemeen Dagblad, in an article titled "Joris Ivens: Honesty Lasts Longest," described the minister's presentation as having been a "well-chosen bowing of the knee" to a man who had been the victim of a "moral death sentence" because he had chosen the side of the Indonesian nationalists. ${ }^{86}$ The battle seemed over on this aspect of the memory of decolonization.

However, in 1985, Michel Korzec and Hans Moll published an article in Intermediair, a weekly aimed at university graduates and professionals. They accused Ivens of being an apologist for mass murderers, comparing his films with the propaganda of Goebbels. ${ }^{87}$ The following month student magazine Propria Cures published an article that questioned why the whole of intellectual Holland had put "Chairman Ivens" on a pedestal. ${ }^{88}$ In 1988, a young writer, Jan Willem Regenhardt, published an article in HNMagazine

81 Henk ten Berge, "De Vliegende Hollander zal in eigen land nog die grote film maken," Algemeen Dagblad, 17 January 1980.

82 Ton Regtien, "Ik ben een zoon van de revolutie van 1917," De Waarheid, 23 October 1982.

83 Quoted in Schoots, Living Dangerously, 353.

84 Quoted in ibid., 354.

85 Quoted in ibid.

86 Constant Wallagh, "Joris Ivens: Eerlijk duurt't langst," Algemeen Dagblad, 13 September 1985.

87 Michel Korzec and Hans Moll, "Het Heilig verklaren van Joris Ivens," Intermediair, 4 October 1985 .

88 Jos den Bakker, “Voorzitter Ivens," Propria Cures, 16 November 1985. 
about Ivens' "anti-Dutch film.." ${ }^{89} \mathrm{He}$ accused Ivens of "unjust and cowardly" behaviour in 1945, and suggested that Ivens' account of events was incorrect. In fact, Regenhardt's article was based on a mediocre assignment he had completed for his bachelor's degree. ${ }^{90}$ It was the academic equivalent of a hatchet job.

Ivens remained a divisive figure, partly because his films were considered to have been communist propaganda, but also because he had chosen to support the cause of Indonesian independence. Most of all, he remained a controversial figure as long as Dutch collective memory was unwilling to pursue an act of recollection based on a critical assessment of the past.

\section{Oeroeg: A Novella}

Since the early 1930s, a Dutch organization called the Collectieve Propaganda van het Nederlandse Boek (CPNB, Collective Promotion for the Dutch Book) has had the custom of giving away a new work of literature during a socalled Boekenweek (Book Week). From the 1940s through the 196os, the book appeared anonymously and the reading public could enter a competition and submit their guesses as to the identity of the author. In 1948, the committee chose a novella by the name of Oeroeg by Hella S. Haasse, which had been submitted under the Malay pseudonym of "Soeka toelis" ("Like to write"). $\cdot{ }^{91}$ Consequently, 145,000 copies of Oeroeg were given away as the Boekenweekgeschenk (Book Week gift). Over 24,00o readers participated in the competition to guess the author, though only a meagre 672 got it right. ${ }^{92}$ As one journalist commented at the time, the relationship between the two male characters had been narrated so convincingly that most readers had assumed that the writer was a man. ${ }^{93}$

Haasse's representation of the twilight years of Dutch rule in Indonesia had a huge influence in shaping a Dutch collective memory of the period. It proved to be the most successful Book Week gift ever; becoming one of

89 Jan Willem Regenhardt, "De omkeertruc van Joris Ivens," HNMagazine, 24 September 1988. 90 Jan Willem Regenhardt, Joris Ivens: Hoeksteen van aktieve culturele betrekkingen tussen de Verenigde Staten en Nederlands-Indië (Kleine scriptie, 1982) u.p., archived at NIOD Institute of War, Holocaust and Genocide Studies, Amsterdam, scr. 648.

91 "Hella S. Haasse schrijfster van novella 'Oeroeg," Het Vrije Volk, 16 April 1948.

92 "Uitslagen Boekenweekprijs vraag: Hella Haasse schreef 'Oeroeg," Leeuwarder Courant, 16 April 1948; "Prijsvraag - Boekenweek Hella S. Haasse schreef 'Oeroeg,' De Volkskrant, 16 April 1948.

93 M.J. Francken, “'Oeroeg' van Hella Haasse,” De Vrije Pers, 4 December 1948. 
the most widely read and best loved books of modern Dutch literature. The novella has been reprinted more than 50 times, is studied in secondary schools and has been the subject of master's theses and doctoral dissertations. It formed the basis of a successful movie in 1993. In October 2009, one million copies of Oeroeg were distributed free of charge in Dutch libraries and schools, while in Jakarta an Indonesian translation was presented. ${ }^{94}$ The entire novel, printed on huge posters, was hung in bus shelters throughout the Netherlands and Belgium. It would seem that every Dutch household must own a copy of this undisputed classic of Dutch literature. In the 199os, one journalist referred to it as "one of the most read books in post-war Dutch literature. ${ }^{.95}$ Clearly, this work qualifies as being what Pierre Nora has called a lieux de mémoire, a place "where memory crystallizes and secretes itself." 6

Hella Haasse was born and raised in the Dutch East Indies, but had lived in the Netherlands for a decade. Oeroeg was her debut novel. Yet, despite her long and illustrious career, it is her first slim novella of little more than 70 pages for which she is best remembered, not least because of the historical significance of the book. The novella is set in the Dutch East Indies and tells the tale of the childhood friendship between a Dutch totok boy and his native Indonesian friend called Oeroeg, and how this friendship collapsed as they grew older and Oeroeg became an Indonesian nationalist. As a novel set in the time of decolonization in the middle of the war of decolonization, it couldn't have been more topical.

The book opens with words that seem prophetic: "Oeroeg is burnt like a seal into my life [...] more than ever at this moment when every contact, every meeting has been reduced forever to the past." ${ }^{\text {" }}$ Further, "Maybe I am stimulated by his [Oeroeg's] irrevocable, incomprehensible otherness, that secret of spirit and blood, that for child and lad created no problem but that now seems all the more tormenting. ${ }^{n 8}$ The young narrator paints a picture of life in the Indies that borders on the Rousseauesque, with Oeroeg being the admired embodiment of the young Noble Savage while the narrator feels ashamed of his own "freckles, and my reddening and peeling in the sun and I envied Oeroeg his even dark colour." 99 The narrator's father is the chief of the tea plantation and he worries about his son's relationship

94 Bloembergen, “Oeroeg," 422.

95 Rob de Kam, “Hans Hylkema verfilmde klassiek boek van Hella Haasse: 'Oeroeg' - woorden in plaats van beelden," Nieuwsblad van het Noorden, 11 June 1993.

96 Nora, "Between Memory and History," 7.

97 Haasse, Oeroeg, 13.

98 Ibid.

99 Ibid., 16. 
with Oeroeg: "You are going native [Je verindischt]. That worries me."100 No doubt, the father suffered from the common worry of Dutch colonials about "the contaminating influence of servants on European children."

As teenagers, the boys remain best friends, and Oeroeg is one of the few natives to receive a good education. During these years, we learn that Oeroeg "did his best to undo anything that reminded him of the past. He only spoke Dutch, his clothing was obviously Western. [...] [H]e did his best to pass for a half-blood." ${ }^{102}$ Nevertheless, the narrator adds: "Neither clothing nor attitude could make him what he was not; one of us." ${ }^{\prime 103}$ Oeroeg gradually discovers that he can never become Dutch. Instead, he migrates towards anti-Dutch nationalism, and the boys grow apart. The narrator travels to Holland for his studies just before the outbreak of World War Two, survives the German occupation without incident, is then called up for his military service and is sent back to the Dutch East Indies to help quell the disorder there. ${ }^{104} \mathrm{He}$ finds himself near his childhood home, and, dressed in Dutch military uniform, visits a small lake, Telaga Hideung, that holds strong memories for him. It was here that Oeroeg's father had drowned while saving the narrator's life. Then, amazingly, he comes face to face with Oeroeg, now an armed Indonesian nationalist. Oeroeg tells him: "Go away, otherwise I'll shoot you. You have no business here."105 The story closes with the narrator's words: "It goes without saying that I didn't understand him. I knew him, like I knew Telaga Hideung - as a mirrored surface. I never fathomed the depths. Is it too late? Am I forever a stranger in the land of my birth, on the ground from which I never want to be moved? Time will tell., ${ }^{106}$ Of course, time did tell, and within two years of the publication of Oeroeg, the Dutch had lost their colony and Haasse, together with 300,00o other totoks and Indos, found herself permanently estranged from the land of her birth.

Oeroeg is a memory novella. Haasse had returned, from a point distant in place and time, to the beloved Indies of her childhood and youth, to create a representation of memory. Oeroeg is her attempt to say goodbye to the Dutch East Indies, but the grief that is evident in her prose demonstrates the profound sadness of mourning. For some of the book's first readers it might have been simply a good story, a straightforward tale of friendship,

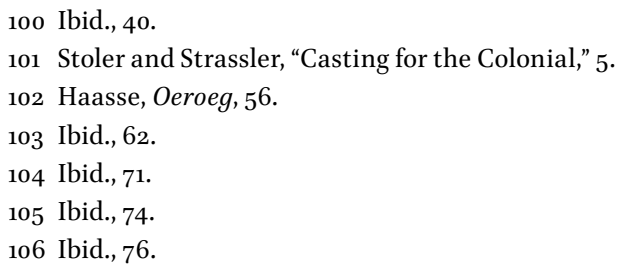


laced with tropical atmosphere ${ }^{107}$ However, given the contemporary state of affairs, the context of the story could not have been lost on the reader.

A reviewer in the Nieuwe Rotterdamsche Courant argued that it had undeniable literary value. ${ }^{108} \mathrm{~A}$ reviewer in the Algemeen Dagblad remarked that the "clear beauty" of the prose compelled the reader with admiration. ${ }^{109}$ Indeed, all of the initial Dutch reviewers remarked on the literary quality of the writing. Some also saw political connotations. Van Randwijk wrote the first substantial review in Vrij Nederland. He hoped that "the novel will contribute to the interest and empathy of the Dutch for Indonesia" of which there was, according to Van Randwijk, a distinct lacking. ${ }^{110}$ On the other hand, the reviewer of Het Vrije Volk was relieved that the book was simply a good story, free of any political standpoint. ${ }^{111}$ Some reviewers, including Van Randwijk, felt that the ending was weak. ${ }^{112}$

On the other hand, C.J. Kelk in the left-wing De Groene Amsterdammer saw in the book "a childish declaration of love by white for brown, and at the same time a concerned and hidden declaration of love and a declaration of independence of the West to the strange, nostalgia inducing, mysteryfilled birthplace." ${ }^{113}$ In the socialist De Vlam, Jef Last also saw in Oeroeg political repercussions: "a precious gift to those for whom the freedom of the oppressed, coloured class is important. [...] Oeroeg helps us understand the soul of the Indonesian revolutionary."114

Some reviewers with an Indische background were harder on the book than their European colleagues. Haasse was attacked for creating a caricature in the person of Oeroeg. ${ }^{115}$ Two reviews appeared in the Batavian journal Orientatie. The first, from Dirk de Vries, focused on the literary aspects of the work, but three months later Indo writer and activist Tjalie Robinson accused Haasse of being the representative of a narrow totok community, unable to really understand his world. ${ }^{116}$ His review was filled with contempt, declaring "the book is Wrong., ${ }^{117}$ As Sarah Fen argues, Robinson's attack

107 “Boekenweekgeschenk: De novella ‘Oeroeg,'” De Tijd, 21 February 1948.

108 Anonymous, "Vriendschap in de tropen," Nieuwe Rotterdamsche Courant, 21 February 1948.

109 B.S., “'Oeroeg' Geschenk 1948,” Algemeen Dagblad, 28 February 1948.

110 H.M. van Randwijk, “Oeroeg: een bekroonde novella," Vrij Nederland, 28 February 1948.

111 R. Blijstra, "Het geschenk," Het Vrije Volk, 21 February 1948.

112 H.M. van Randwijk, "Oeroeg: een bekroonde novella," Vrij Nederland, 28 February 1948; G.K., “De Boekenweekuitgaven,” De Waarheid, 6 March 1948.

113 C.J. Kelk, "Oeroeg, een begin of een einde?," De Groene Amsterdammer, 3 April 1948.

114 Jef Last, “Werk van Hella Haasse," De Vlam, 23 April 1948.

115 Bloembergen, “Oeroeg," 425.

116 Ibid.

117 Tjalie Robinson, “Nogmaals Oeroeg," Oriëntatie: Cultureel Maandblad 9 (1948): 56. 
seemed to be predicated on the idea that Haasse's white skin excluded her from having an authentic memory of the Dutch East Indies. ${ }^{118}$

One might conclude that Oeroeg provides an example of what Said calls "'they' were not like 'us,' and for that reason deserved to be ruled." ${ }^{\prime \prime 9}$ We only come to know the thoughts of the narrator, while the sole main Indonesian character, Oeroeg, is rendered mute and is made visible only through the European gaze. For the narrator, Oeroeg remains the incomprehensible Other. Inevitably, he becomes an enigma for the reader, in the best (or worst) Orientalist tradition.

On the other hand, the chasm that opens between the two friends is clearly due to the political ignorance of the narrator, his inability to really know Oeroeg due to his unquestioned acceptance of the colonial structure; this ignorance is clearly demonstrated to the perceptive reader and was apparent to some early reviewers. ${ }^{120}$ The narrator even admits his own fault when he accepts that he had only known his Indonesian friend "as a mirrored surface." However, because of the absence of multiple perspectives in the novel, and because the single narrator never questions the hegemonic, colonial authority, the justification of colonialism never becomes an explicit issue. The problems between the narrator and Oeroeg are played out at the level of personalities, and the underlying systems of inequality remain out of sight and unspoken. The difficulties in the relationship between the narrator and Oeroeg are mirrored by the differences between ruler and ruled, between white and brown, but are played out in terms of individuals. This means that politics fail to become explicit, which is why the committee may have approved of it in the sensitive year of 1948 .

It has been argued that Haasse worked narrowly within the traditional colonial discourse and authored a story that offers a variation of the colonial cultural project in which the exotic other is collected, examined, classified, measured and narrated. Such is the conclusion of Pamela Pattynama, who reads Oeroeg as an example of colonial (as opposed to postcolonial) literature. ${ }^{121}$ Oeroeg is represented as an Orientalized Other. Haasse's descriptions of Java unavoidably reminds one of Said's famous words: "The Orient was almost a European invention, [...] a place of romance, exotic beings, haunting memories and landscapes, remarkable experiences." ${ }^{122}$

118 De Mul, Colonial Memory, 59.

119 Said, Culture, xii.

120 G.K., "De Boekenweekuitgaven," De Waarheid, 6 March 1948.

121 Pattynama, "Postkoloniale Erinnerung," 120-122.

122 Said, Orientalism, 1. 
Haasse's approach seemingly qualifies as Orientalism according to Said's definition: "Orientalism is a style of thought based upon an ontological and epistemological distinction made between 'the Orient' and (most of the time) 'the Occident."'123

Certainly, the totok narrator mediates the character of Oeroeg. Haasse refrains from availing of any literary trope that would permit us to witness Oeroeg representing his own feelings, thoughts and emotions. He is the silent subaltern. From this perspective, Oeroeg essentializes the myth that East and West are forever divided into two unchanging identities. This essentialism is what Said objected to when he described Orientalism as being a system of thought suggesting "both an enduring Oriental reality and an opposing but no less enduring Western essence, which observes the Orient from afar and, so to speak, from above."124 It is almost as if he is describing the narrator of Oeroeg, when Said, discussing Kipling's Kim, writes that the "imperial European would not or could not see he or she was an imperialist and, ironically, how it was that the non-European in the name of circumstances saw the European only as imperial." ${ }^{125}$

Nevertheless, there is some intimation that Haasse's narrator, while not questioning European hegemony, nevertheless has a dawning realization that other perspectives are possible. We are introduced to the Dutch character Gerard Stokman, the son of a soldier and are told that he "had lost his heart to Java, the hunt and the outdoor life." Both the narrator and Oereog are in awe of this man, who tells them, "I never want to go to Holland." ${ }^{126}$ Stokman lives a simple life and every weekend disappears into the mountains to go camping; one evening, while Oeroeg and the narrator camp with Stokman, we even catch a glimpse of a native character, Stokman's coolie, Ali, who turns out to be a Sundanese teller of stories, of "animal fables and myths of demi-gods and miraculous creatures" (37).

One day, having noticed that other totok children treat Oereog differently, speaking to him like to a servant, the narrator naively asks Stokman: "Is Oeroeg less than we are?" Stokman answers that a panther is different from an ape, and asks: "[B]ut is one of the two less than the other?" He adds: “To be different - that is normal. [...] [T] o be worth less or more because of the colour of your face or because of what your father is - that is nonsense" (42).

123 Ibid., 2.

124 Ibid., 333.

125 Said, Culture, 196.

126 Haasse, Oeroeg, 34. 
More poignant is the character of the totok Lida, a former nurse who had emigrated from Holland, who had cared for the narrator and Oeroeg when they were teenagers but took a special interest in Oeroeg. As the narrator becomes estranged from his childhood friend, Lida grows closer to Oeroeg. She eventually becomes a nurse in a native hospital and supports the Indonesian nationalist cause. When the narrator visits Oeroeg, he finds him living in a household with Lida, and the family of Abdullah Harudin, a youth with an Arab background who, like Oeroeg, is an anti-colonialism activist. The narrator doesn't know what attitude to take towards his old friend. He notices that Lida, when she walks, has the stride of a local woman. The three fail to recover their old feeling of ease. "The split between their world and mine was complete," the narrator informs us (70).

Oeroeg, the native or inlander, has turned towards Indonesian nationalism, but so too have the totok Lida and the Arab Abdullah Harudin. We fail to really connect with their motivations, their arguments are basic, but only because the narrator lacks an understanding for the motivations of the three multicultural characters. The three make up a hybrid group, but the narrator does not realize that this failure to understand their motives is due to his own shortcoming, his own unquestioning acceptance of the colonial system. This is not Haasse's failure. Haasse offered enough information so the perceptive postcolonial reader could see the unreliability of the narrator. The politics of the book are hidden, but present.

It can be argued that the novella covers the period of decolonization in a superficial manner. The narrator travels to the Netherlands to study engineering in Delft. The German occupation of the Netherlands, which he experiences, is covered in a couple of lines; likewise the Japanese occupation of his place of birth. After the war, he hears about the "disorderly situation" that is the legacy of the Japanese occupation (71). He returns to the East Indies as the first "police action" is taking place. As an engineer, the narrator repairs bridges that were destroyed by the republicans (72). He witnesses a landscape blackened by the revolutionaries' scorched-earth policy (73). Then, finally, he has that fateful encounter with his former friend, that ends with those words, "Go away, otherwise I'll shoot you. You have no business here" (74).

Let us consider this. The post-war problems are those of disorder, not revolution. The cause of the disorder is the Japanese occupation, not the injustices inherent in colonialism. The actions of the Dutch are police actions, not warfare. Destruction is caused by rebels, not by the Dutch who repair bridges. Such are the views of the narrator. But are we supposed to believe him? 
The narrator of Oeroeg is unreliable, locked within his unquestioning acceptance of the hegemonic structures of European imperialism. His failure is his belief in the inevitability of the clash of civilizations, not realizing that the cause of the clash should be sought within the inequalities inherent in the colonial project, rather than in any essentialized differences between East and West. As Stefanie van Gemert has argued, the narrator's "inability to recognise and empathise with Oeroeg" was Haasse's subtle way of criticizing "a more general, political blindness in the Netherlands: a Dutch inability to recognise violence when discussing the Indies." ${ }^{27}$ Indeed, Gemert points out that none of the reviewers in the 1940s even mentioned the real political violence of the war of decolonization in their reviews - an early example of unremembering. ${ }^{128}$

In order to create a representation for remembering decolonization, Oeroeg was perhaps too subtle. The novel could have become a springboard for open discussion. That it did not is not a failure on the part of Haasse's novel. By reducing the collapse of their friendship to the inevitability of misunderstanding when children come from different cultures and by providing a metaphor for the collapse of the Dutch colonial project, the reception of Haasse's work began a process of unremembering, rather than remembering. The reading, discussing and rereading of Oeroeg, rather than creating a collective memory of decolonization, initiated a process in which it was thought that colonization was a tragic error, bound to fail due to the unbridgeable divide between the culture of the totok/Indos on the one hand and the culture of the natives on the other. Details regarding decolonization like "police actions," massacres, possible war crimes could remain unspoken.

Oeroeg became a site of longing made more acutely painful because it was a longing, not only for a world that no longer existed, but could no longer exist. In this sense, the reading and rereading of Oeroeg reinforced a repetition-memory, as suggested by Ricoeur, initiating and continuing a collective unremembering sustained by the grief that came from a traumatic loss. Oeroeg became an instrument through which a melancholic longing for the past could be acted out. This mythical memory conveyed a simple message, untested by past reality: that the loss of the colony had been inevitable because the two cultures, the European and the Indonesian, had become estranged from each other due to mutual Otherness. It is ironic, as Marieke Bloembergen puts it, that Oeroeg came to be seen as the example of politically

127 Van Gemert, “'A Sort of Wishful Dream,"” 125.

128 Ibid., 123-124. 
incorrect nostalgia for the colonial past, while in fact Haasse's novella provided "the place [aanknopingspunten] to reflect upon the complexity of that colonial past." ${ }^{129}$ Instead, it was read as a representation of what Maier has labelled the "mutual othering" of the waning years of colonialism. ${ }^{130}$

\section{Historiography of the Conflict: Early Beginnings}

\section{Hubertus J.van Mook}

Former Lieutenant Governor-General Hubertus J. van Mook's Indonesië, Nederland en de Wereld (Indonesia, the Netherlands and the world), was published in February 1949. Van Mook had been at the helm of Dutch government in the colony, leading the Dutch government in exile in Australia during the Japanese occupation and returning to Batavia in 1945. An enlightened colonial, Van Mook devoted his life to the betterment of the colony in which he had been born. As a member of a group of intellectuals associated with the periodical De Stuw, he advocated throughout the 1930 s for the development of the colony until the point when an Indonesian commonwealth could be accepted as an independent nation. ${ }^{131}$ This earned him the enmity of Carel Gerretson, professor at the University of Utrecht, who argued that Van Mook and the De Stuw members formed a sort of Girondist club whose aim was to betray the Netherlands by creating an enlightened despotism in the colony under their control. ${ }^{132}$ During the Indonesian War of Independence, Van Mook had opened negotiations with the Indonesian nationalist leadership, earning him the wrath of die-hard colonialists. However, he had also ordered the first "police action." Political in-fighting led to his removal from power in late 1948. Indonesië, Nederland en de Wereld was his attempt to tell the story.

Not surprisingly, he did not blame himself for the bloodshed. Nor did he blame the government in The Hague, though he revealed some of the miscalculations of his conservative fellow colonials. Mainly Van Mook blamed the interference of inexpert foreigners - the British and the naive Americans, the unreliable Australians, the newly independent Indians, the calculating Russians and their communist satellites, and the do-gooders at the United Nations.

129 Bloembergen, “Oeroeg," 431.

130 Maier, "Escape from the Green," 88.

131 Van den Doel, Afscheid, 43-44.

132 Gerretson, Indië, 16-27. 
At the founding conference of the United Nations in San Francisco in 1945, Van Mook had rejected the notion that the Dutch East Indies should become a trusteeship of the UN. ${ }^{133}$ Months after his book's publication he still maintained that it was chiefly the concern of the Netherlands and Indonesia themselves. ${ }^{134} \mathrm{He}$ argued that the government of the Netherlands had always defended the best interests of the Indonesians. ${ }^{135}$

Van Mook began his book by warning the reader of the new imperialism of the Soviet Union. The Soviets, he claimed, preyed on the poor and weak but their ultimate aim was not liberation but driving out the West. They are helped, he added, by fellow travellers such as Australia, who in the United Nations stood on the same side as the Soviets. ${ }^{136}$

An initial error of perception, according to Van Mook, was for the Labour government in Britain to accept all Asian liberation movements at face value. The British committed a grievous error by semi-officially recognizing the Indonesian republican movement (90-91). He repeated this point at a lecture at Chatham House in March 1949. ${ }^{137}$ Had the British quickly disarmed the Japanese, rather than permitting the latter to hand over their weapons to Indonesian nationalists, "a lot of misery would have been spared the Indonesians and Dutch."138

The situation in 1945 was complicated by the strike by Australian workers, inspired by the Australian Communist Party (88), as well as the British refusal to allow Dutch troops to return to Java and Sumatra (95). Although Van Mook was repelled by the idea of negotiating with the collaborator Sukarno, in October 1945 he began personal negotiations with the nationalists, including Sukarno. This caused widespread negative reactions among the public in the Netherlands and began a rift between Van Mook and the authorities in The Hague (102-105). The minutes of a meeting of the Dutch cabinet reveal that they considered Van Mook's behaviour to be "incorrect and not acceptable to the government" and immediately began discussing the process of replacing him. ${ }^{139} \mathrm{~A}$ week later, Minister for Overseas Territories Logemann (and fellow De Stuw member) wrote to Van Mook, letting him

133 Van Mook, Indonesië, 45.

134 Van Mook, “Indonesia," 561.

135 Ibid., 571.

136 Van Mook, Indonesië, 7-11.

137 Van Mook, "Indonesia and the Problem," 274.

138 Van Mook, Indonesië, 77.

139 "Notulen van de vergadering van de ministers op 1 nov. 1945," (Minutes of the Cabinet Meeting 1 Nov. 1945), in Wal et al., Officiële Bescheiden, vol. 1, 504-506. 
know that important sections of the Dutch public and parliament considered his meeting with Sukarno an act of "national treason."140

Shortly thereafter Van Mook visited the Netherlands and was alarmed by the strong sentiments that he encountered there, as well as the stridency of some voices. ${ }^{141}$ Similarly, when Dutch authorities sat down with Indonesian nationalist leaders at the Hoge Veluwe Conference in April 1946, Van Mook was disappointed by the exaggerated security measures, as well as the refusal of the Dutch government to allow Van Mook to make any public statements and by the negative attitude of the Dutch press. From this time onward, he tells us, he became the target of a criticism and lies in the Dutch press, from which the government failed to defend him adequately (132-140).

Nevertheless, negotiations between the two sides continued in Indonesia itself, culminating in November 1946 in the Linggadjati Agreement. According to Van Mook, many believed that the conflict was now over. Feelings of optimism seemed confirmed when the news reached Indonesia that a majority in the Dutch parliament had voted to ratify the accord. Alas, it became clear that what the Dutch authorities had accepted was a truncated version of Linggadjati - an interpretation of the original agreement of their own devising which was rejected by the Indonesians (157-169).

Van Mook mentioned that around this time he ordered a special military action in South Celebes, in order to put an end to the nationalist regime of systematic terror on this island. He admitted that during the pacification of the island, the Dutch had committed "excesses" (171). Van Mook writes that Dutch soldiers had become the daily targets of nationalists and the breakdown in law and order had become almost unbearable (165). At last, Van Mook, the Commission General and the government in The Hague concluded that a military solution was the only option (182).

He described the "police action" of 1947 as a military success, with Indonesians greeting Dutch soldiers with relief. It seemed logical that the cleansing of the republican areas should continue but the UN intervened. A Security Council resolution called for a ceasefire and this was immediately accepted by the Dutch government. Van Mook felt betrayed; he had been forced to stop, with the job only half done (182-188). Speaking of the Security Council's resolution some time later, he called it "a calamity."142 Not only

140 "Logemann (minister van oversees gebiedsdelen) aan Van Mook (lt. governeur-generaal), 9 nov. 1945," (Logemann (Minister of the Colonies) to Van Mook (Lt. Governor General), 9 November 1945), in Wal et al., Officiële Bescheiden, vol. 2, 1-5.

141 Van Mook, Indonesië, 111-112.

142 Van Mook., "Indonesia," 278. 
that, but the Netherlands also accepted the presence of a UN-appointed Commission of Good Services in Indonesia, thereby allowing what Van Mook considered to be "inexpert international meddling."

Van Mook tells us that the communist influence among the republicans grew stronger and that non-communist nationalists began to draw nearer to the Soviet Union as they awaited a third world war they expected Russia to win. He argued that the members of the Commission of Good Services were blind to the true nature of the republican government and that the American in the group had concluded that a communist takeover of the republican area could only be avoided with far-reaching concessions. ${ }^{144}$ Van Mook's sense of betrayal deepened when it became clear that by mid-1948 the authorities in The Hague had come to consider him an obstacle that had to be removed. On 5 October 1948, Prime Minister Drees informed Van Mook that his services were no longer required. ${ }^{145}$ In November, he departed from Indonesia. The following month the Dutch began their second military "police action." This too was brought to an abrupt end "by an inevitable new action of the Security Council."146

Van Mook concluded his book in February 1949 with a call for the Indonesians and the Dutch to together build something great, to serve as a beacon for Southeast Asia. ${ }^{147}$ One cannot help but conclude that the type of people Van Mook had in mind to construct this beacon were people like himself. He desired reform from the top down. He believed that Indonesia should be free, after a transition under European (that is, colonial) tutelage. Ultimately, it had to be Europeans like Van Mook who would judge when the natives were ready for independence. This was the ideology of late colonialism, described by Syed Hussein Alatas: "an ideology that recognized the need to improve native welfare and for the eventual independence of the country, but only after a certain amount of 'training and preparation."'148 Enlightened colonialism was still colonialism.

Van Mook's colonial imagination could not comprehend the power of the Indonesian revolution that surrounded him, because his cultural archive would not allow it. As Michel-Rolph Trouillot has argued, for those who lead

143 Van Mook, Indonesië, 212.

144 Ibid., 210.

145 “Minister-president (Drees) aan Lt. gouverneur-generaal (Van Mook) 5 okt. 1948," ("Prime Minister (Drees) to Lt. Governor-General (Van Mook), 5 Oct. 1948," in Wal et al., Officiële Bescheiden, vol. 15, 339-340.

146 Van Mook, Indonesië, 220.

147 Ibid., 229.

148 Alatas, Myth of the Native, 14. 
a system of colonial domination, radical revolution is not only incomprehensible, it is unthinkable. ${ }^{49}$ Van Mook's account therefore ignored the growth of Indonesian nationalism. He could only see it as an extension of Japanese power. This blind spot continued to dog Dutch representations of the war, despite H. Bouman's PhD dissertation (1949). Bouman cogently argued that an understanding of Indonesian nationalism was complicated by pre-war colonial attitudes (Said's "cultural archive"), leading to its underestimation. ${ }^{150}$ Dutch repression during the 1920 and 1930 s had made colonialism seem safe, but led the Dutch to mistake "the lack of a nationalist movement for a lack of nationalism."151

Van Mook was not alone in underestimating the force of Indonesian nationalism. In an article from 1942, foreign affairs expert Eelco van Kleffens argued that "when Japan invaded and occupied the Netherlands Indies, the native population in the islands, so far from making an attempt to rise against Holland or even exploit the situation, [...] remained loyal to the kingdom of which they form a part." ${ }^{2}{ }^{2}$ This wishful thinking is present in the report from Frans H. Visman from June 1945, where he suggested that in liberated areas of Indonesia the population "eagerly reported" to the Dutch authorities. ${ }^{153}$

In Van Mook's representation, the Dutch would have prepared Indonesia for independence under the Dutch crown. The Japanese occupation initiated a catastrophe. Sukarno had been a quasi-fascist collaborator of the Japanese. The Dutch were needed in Indonesia to counteract Soviet expansionism but were betrayed by their inexpert Western allies and the UN. These tropes would reappear in a repetition-memory that contributed to unremembering for decades to come. What Van Mook represented is that the Dutch were not fighting a war of reconquest, but a police action that, once successful, would lead to decolonization through a peaceful process.

\section{Jacques de Kadt}

In May 1949, a counterargument appeared from the leftist parliamentarian Jacques de Kadt. His De Indonesische tragedie: Het treurspel van gemiste kansen (The Indonesian tragedy: A tragedy of missed chances) accused the

149 Trouillot, Silencing the Past, 82-90.

150 Bouman, Enige beschouwingen, 4-5.

$15^{1}$ Ibid., 32-33.

152 Van Kleffens, "The Democratic Future," 96.

153 Visman, "Provisional Government," 184. 
Dutch government of following a policy whose goal was to deny Indonesia real freedom. Van Mook's aim, according to De Kadt, had been to create a federation composed of weak, small states over which the Netherlands could continue to exert its control. ${ }^{154} \mathrm{He}$ compared Van Mook to an enlightened despot. ${ }^{155}$

Jewish, and a former communist activist, De Kadt had narrowly escaped with his parents and brother from the German invasion of the Netherlands in 1940, arriving in the Dutch East Indies that same year. Upon arrival he was detained, being considered a dangerous Trotskyist with connections to Hatta and Indonesian nationalists. After the Japanese invasion, he and his family were interned in a Japanese prison camp. Neither of his parents survived. After the defeat of the Japanese, De Kadt began writing for Het Parool. His articles argued against Dutch military intervention in Indonesia. In late 1945, he published an article in the British New Statesman and Nation calling on Prime Minister Atlee to not commit a crime against liberty by aiding the Dutch government in Indonesia. In March 1946, De Kadt left the colony, returning to the Netherlands to join the Labour Party. He was elected to parliament in 1947, where he was one of a minority that condemned Dutch military actions. Writing De Indonesische Tragedie was his way of expressing his anger. ${ }^{156}$

De Kadt's main purpose was to attack the type of Dutch smugness that will not listen to foreigners, because the Dutch know best. ${ }^{157} \mathrm{He}$ attacked the belief that the colony was run by a democratic leadership, pointing out that even under the threat of Japanese invasion the leadership could not imagine mobilizing the Indonesian majority (17). Instead, the colonists lived in a bubble, isolated from the locals, with the exception of their servants. For them, Indonesian independence lay decades or even centuries in the future. De Kadt pointed out that people came by the tens of thousands to hear Sukarno speak during the 1920s. The response by the authorities was repression by a type of moderate Gestapo. Under such conditions, where even mild expressions of nationalism were confronted with repression, Europeans remained ignorant of the depth of Indonesian discontent. Indeed, Dutch contempt for Indonesian nationalists distorted their judgement so that, when the colonial leadership fled to safety in Australia, no one considered bringing

154 De Kadt, De Indonesische tragedie, 143.

155 Ibid., 111.

156 Havenaar, De tocht, 155-167.

157 De Kadt, De Indonesische tragedie, 5-6. 
their prisoners with them (26-71). Consequently, Sukarno and Hatta, liberated by the Japanese, worked with the Japanese to make Indonesian nationalism a mass movement.

De Kadt argued that the panic demonstrated by the Dutch on the eve of the Japanese invasion, as well as their "exceptionally despicable" attempt to defend themselves, destroyed their reputation among most Indonesians, who were happy to see them defeated (57-59). He attacked the myth that Sukarno and Hatta were Japanese collaborators. They worked with the Japanese because they were promised home rule. As a consequence, Indonesians were placed in positions of economic and civil service leadership that they could never have dreamt of achieving under the Dutch. He argued that most Indonesians had turned against the Japanese by 1945, but remained devoted to Sukarno (72-81).

De Kadt reflected on his own experience in a Japanese prison camp. He found the atmosphere among his fellow prisoners not particularly anti-Japanese, but rather anti-Indonesian. The common point of view was that the "natives" had betrayed the Dutch. They found having Indonesian leadership in their camps, instead of Japanese, particularly humiliating. A common point of view, he claimed, was that the Indonesians lacked gratitude for all the things the Dutch had done for them. After the liberation he found himself the only one who claimed that Sukarno and the nationalists would have a permanent influence on Indonesian politics (86-92).

Unlike Van Mook, De Kadt argued that the republic was anti-Japanese, a creation of the Indonesians themselves. Contrary to Van Mook, he expressed understanding for the Americans who were reluctant to fight for old-fashioned Dutch colonialism and he likewise argued that the British had no option but to deal with the Indonesian republican government while the Dutch still spoke the outdated language of the pre-war colonial world. The short-sightedness of the Dutch was shown by their resolve to negotiate with only "good" Indonesians and never with collaborators like Sukarno. In other words, as Jennifer Foray puts it, when the Dutch authorities were confronted with a major problem in their largest colony, "they viewed the conflict through the interpretive lenses forged out of five years of German occupation" and consequently, "memories of World War II overlapped and informed understandings of the decolonization process then unfolding in Indonesia." ${ }^{n}{ }^{8}$ 
De Kadt described Van Mook's approach towards the Indonesian nationalists as follows:

Just a couple of months earlier they had declared an independent republic and now they were invited to give this up in exchange for a return to the old colonial relationship with the understanding that this relationship would be, say, 10 or 20 per cent better than before the war.

He judged that the colonial attitudes of leaders like Van Mook, Minister Logemann and Prime Ministers Schermerhorn and Drees were "the most backward in the world."159 Alternative plans were ignored by Van Mook and the Dutch authorities. It was this obstinate behaviour of the colonial Dutch, and the British, that unleashed the violence of the Bersiap period, according De Kadt (115-126).

The failure of the Hoge Veluwe negotiations marked an early missed chance for the Dutch, while the changes that the Dutch brought to the Linggadjati Agreement were Van Mook's attempt to ensure that a federated Indonesian state would be a weak collection of puppet states under Dutch control (127-134). He accused the Dutch leadership of having little patience for painstaking negotiation, especially the Catholics among the leaders (139-160). Thus they choose the military solution.

De Kadt described the second "police action" as the violence of a totalitarian state destined for bankruptcy. De Kadt finished his j'accuse by declaring that the Netherlands is following a suicidal policy based on lies and trickery. The only hope was to quickly grant full sovereignty to Indonesia (176-197). Furthermore, he predicted that Indonesia would not only gain independence, but that it would fully break with the Netherlands and be, for the Netherlands, "completely lost" (199). Finally, he maintained that what was needed in 1945 was Dutch recognition of full Indonesian independence. This would have allowed close connections to continue, based on economic, cultural, technological and organizational cooperation (201). What remains instead is the shameful narrowmindedness, incompetence and smugness. He concluded: "The idiots who claim that we are right and that the entire world errs, and the even bigger idiots who claim that we are a shining example for the world, deserve to be seen as what they are: people who failed completely and who have caused immeasurable damage to our country and our people" (203). 
Not everyone was pleased with De Kadt's message. He had, after all, attacked not only the colonial conservatives, but also leading socialists like Willem Drees. One journalist, Jan Fabius, sued De Kadt for insulting him and the court ordered the reference to be expunged..$^{60}$ De Kadt's biographer, Ronald Havenaar, claimed that only one reviewer supported De Kadt in all of his major arguments. ${ }^{161}$ Yet Henk van den Doel argues that most historians supported De Kadt's general conclusions. ${ }^{162}$ If this was indeed the case, they succeeded in keeping it to themselves. During the following decades, most historians avoided the topic of the 1945-1949 colonial war altogether.

\section{Bibliography}

Alatas, Syed Hussein. The Myth of the Native: A Study of the Image of the Malays, Filipinos and Javanese from the $16^{\text {th }}$ to the $20^{\text {th }}$ Century and its Function in the Ideology of Colonial Capitalism. London: Frank Cass, 1977.

Bloembergen, Marieke. “Oeroeg.” In Een Open Zenuw: Hoe wij ons de tweede wereldoorlog herinneren, edited by Madelon de Keizer and Marije Plomp, 421-431. Amsterdam: Bert Bakker, 2010.

Bouman, Herman. Enige beschouwingen over de ontwikkeling van het Indonesisch Nationalisme op Sumatra's Westkust. Groningen/Batavia: J. B. Wolters, 1949.

Cottle, Drew and Angela Keys. "From Colonial Film Commissioner to Political Pariah: Joris Ivens and the Making of Indonesia Calling." Senses of Cinema 41 (2006): http://www.sensesofcinema.com/2006/41/ivens-indonesia-calling. Accessed 15 April 2015.

Delmar, Rosalind. Joris Lvens:5o Years of Filmmaking. London: British Film Institute, 1972.

Doel, Henk W. van den. Afscheid van Indië: de valvan het Nederlandse imperium in Azië. Amsterdam: Prometheus, 2000.

Foray, Jennifer L. "The Trauma of Liberation: Dutch Political Culture and the Indonesian Question in 1945." Historical Reflections 41, no. 3 (2015): 79-94.

Gemert, Stefanie van. “'A Sort of Wishful Dream': Challenging Colonial Time and 'Indische' Identities in Hella S. Haasse's Oeroeg, Sleuteloog in Contemporary Reviews." In Discord and Consensus in the Low Countries, edited Jane Fenoulhet, Gerdi Quist and Ulrich Tiedau, 118-132. London: UCL Press, 2016.

Gerretson, Carel. Indië onder Dictatuur. Amsterdam/Brussels: Elsevier, 1946.

160 "Indonesische tragedie," Nieuwsblad van Sumatra, 13 April 1949; "De Kadt's brochure verboden," De Tijd, 14 April 1949; ANP Radio Nieuwsbericht, 14 April 1949, 13:0o.

161 Havenaar, De tocht, 168.

162 Van den Doel, Afscheid, 14. 
Haasse, Hella S. Oeroeg. Amsterdam: Querido, 2009. [1948]

Hagebeuk, Lieke. "Indië verloren, rampspoed geboren? Een analyse van politieke besluitvorming en berichtgeving over de dekolonisatie van Indonesië.” MA thesis, University of Groningen, 2009. http://arts.studenttheses.ub.rug.nl/9242/1/ MA-s1587013-L.Hagebeuk.pdf. Accessed 15 April 2015.

Hanan, David. “Fellow Travellers." Meanjin 66, no. 2 (2007): 52-58.

Havenaar, Ronald. De tocht naar het onbekende: Het politieke denken van Jacques de Kadt. Amsterdam: G.A. van Oorschot, 1990.

Hogenkamp, Bert. "Indonesia Calling: A Film on the Crossroads of Four Continents." Labour History 73 (November 1997): 226-231.

Hogenkamp, Bert. "A Special Relationship: Joris Ivens and the Netherlands.” Joris Ivens and the Documentary Context, edited by Kees Bakker, 183-194. Amsterdam: Amsterdam University Press, 1999.

Jansen Hendriks, Gerda. "Bersiap:Joris Ivens and the Early Indonesian revolution.” Joris Ivens Newsmagazine 9 (November 2003): 20-22.

Jansen Hendriks, Gerda. "Een voorbeeldige kolonie: Nederlands-Indië in $5^{0}$ jaar overheidsfilms 1912-1962." PhD diss., University of Amsterdam, 2014.

Jansen Hendriks, Gerda, Frank Klein and Petter Otten. "The Final Years of the Dutch East Indies as Recorded by Multifilm Batavia." Historical Journal of Film, Radio and Television 5, no.1 (1985): 77-83.

Kadt, Jacques de. De Indonesische tragedie: Het treurspel van gemiste kansen. Amsterdam: G.A. van Oorschot, 1949.

Keizer, Madelon de. 'Mission Impossible'. De bemiddelaarsrol van Frans Goedhart in het Nederlands-Indonesische conflict, 1945-1947." Bijdragen en Mededelingen betreffende de Geschiedenis der Nederlanden 100, no. 3 (1995): 352-379.

Kleffens, Eelco N. van. "The Democratic Future of the Netherlands Indies." Foreign Affairs 21, no.1 (1942): 87-102.

Kok, Rene, Erik Somers and Louis Zweers, Koloniale Oorlog: Van Indië naar Indonesië. Amsterdam: Carrera, 2015.

Maier, Henk M.J. "Escape From the Green and Gloss of Java: Hella S. Haasse and Indies Literature." Indonesia 77, (April 2004): 79-107.

Mook, Hubertus J. van. "Indonesia." International Affairs 25, no. 3 (1949): 274-285.

Mook, Hubertus J. van. "Indonesia and the Problem of Southeast Asia." Foreign Affairs 27 (July 1949): 561-575.

Mook, Hubertus J. van. Indonesië, Nederland en de Wereld. Amsterdam: De Bezige $\mathrm{Bij}, 1949$.

Moor, Jaap A. de. Generaal Spoor: Triomf en tragiek van een legercommandant. Amsterdam: Boom, 2011.

Mul, Sarah de. Colonial Memory: Contemporary Women's Travel Writing in Britain and the Netherlands. Amsterdam: Amsterdam University Press, 2011. 
Nora, Pierre. "Between Memory and History: Les Lieux de Mémoire." Representations 26 (Spring 1989): 7-28.

Pattynama, Pamela. "Postkoloniale Erinnerung an (Niederlandisch-) Indien: koloniale Vergangenheit, kulturelle Erinnerung und Literatur." In Kolonialismus und Erinnerungskultuur: Die Kolonialevergangenheit im kollectiven Gedächtnis der deutschen und niederländischen Einwanderungsgesellschaft edited by Helma Lutz and Kathrin Gawarecki, 111-126. Munster: Waxman Verlag, 2005.

Pieter, Nadap. "Geloof in Nederlands roeping: Koloniale journalistiek in Indonesië tijdens de Politionele Acties 1947-1949." MA thesis, University of Groningen, 2009. http://arts.studenttheses.ub.rug.nl/9593/1/MA-1408097-Pieter-N-scriptie. pdf. Accessed 16 April 2015.

Protschky, Susie. "Burden of Proof: Photography and Evidence of Atrocicty during the Dutch Military Actions in Indonesia 1945-1950." Bijdragen tot de Taal -, Land - en Volkenkunde 176, (2020): 240-278.

Regenhardt, Jan Willem. Joris Ivens: Hoeksteen van aktieve culturele betrekkingen tussen de Verenigde Staten en Nederlands-Indië. (Kleine scriptie, 1982) u.p. Archived at NIOD Institute of War, Holocaust and Genocide Studies. scr.648.

Riemens, J.W.E., ed. Wat gebeurt in Indonesië? Amsterdam: Comite voor Vrede in Indonesië, 1949 .

Said, Edward W. Culture and Imperialism. London: Vintage, 1994.

Said, Edward W. Orientalism. London: Penguin Books, 2003 [1978].

Schoots, Hans. Living Dangerously: A Biography of Joris Ivens. Amsterdam: Amsterdam University Press, 2000.

Shaffer, Deborah and Joris Ivens. "Fifty Years of Political Filmmaking: An Interview with Joris Ivens." Cineaste 14, no. 1 (1985) 12-15, 21.

Sontag, Susan. Regarding the Pain of Others. London: Penguin, 2003.

Sprang, Alfred van. Laatste actie: een cocktail van soldatenleven en politiek in Indonesië. The Hague: W. van Hoeve, 1949.

Stoler, Ann Laura and Karen Strassler. "Casting for the Colonial: Memory Work in 'New Order' Java." Comparative Studies in Society and History 42, no. 1 (2000): 4-48.

Stufkens, Andre. "Joris Ivens: Essays on the Career of a Radical Documentarist: Interview with Thomas Waugh." The Ivens Magazine 18 (December 2013): 30-31. Trouillot, Michel-Rolph. Silencing the Past: Power and the Production of History. Boston: Beacon Press, 1995.

Virilio, Paul. War and Cinema: The Logistics of Perception. Translated by Patrick Camiller. New York and London: Verso, 1989.

Visman, Frans H. "Provisional Government in the Netherlands East Indies."Pacific Affairs 18 (June 1945): 180-187.

Waugh, Thomas. The Conscience of Cinema: The Works of Joris Ivens 1926-1989. Amsterdam: Amsterdam University Press, 2016. 
Waugh, Thomas. "Joris Ivens and the Legacy of Committed Documentary." In Joris Ivens and the Documentary Context, edited by Kees Bakker, 171-182. Amsterdam University Press: Amsterdam, 1999.

Wal, Simon L. van der, Pieter J. Drooglever and Mieke J.B. Schouten. Officiële Bescheiden betreffende de Nederlands-Indonesische Betrekkingen 1945-1950, 20 vols. The Hague: Instituut voor Nederlandse Geschiedenis, 1971-1996.

Wolthuis, Rob. "Voorlichtingsbeleid met betrekking tot Nederlands-Indië 1945-1950: Picturale 'story-telling' als propaganda middel.” MA thesis, Erasmus University Rotterdam, 2008. http://hdl.handle.net/2105/4754. Accessed 6 April 2015.

Zweers, Louis. De gecensureerde oorlog: Militairen versus media in Nederlands-Indië 1945-1949. Zutphen: Walburg Pers, 2013.

Zweers, Louis. “'Silence Is the Best Solution': The Military versus the Media in the Netherlands East Indies 1945-1949." Newsletter of the International Institute for Asian Studies 68, (Summer 2014): 8-9.

\section{Cinema Newsreels}

Brengers van Recht en Veiligheid. Multifilm Batavia. [1947]. Disc 2. Nederlands Indië: Van tropische idylle tot harde realiteit. Hilversum: Netherlands Institute for Sound and Vision, 2011. DVD.

Een Grote Soldaat ging Heen. Multifilm Batavia. [1949]. Disc 2. Nederlands Indië: Van tropische idylle tot harde realiteit. Hilversum: Netherlands Institute for Sound and Vision, 2011. DVD.

Linggadjati in de branding. Multifilm Batavia. [1947]. Disc 3. Einde van Indië; Oorlog in Indonesië. Hilversum: Institute of Sound and Vision/Tijdsbeeld Media, 2011. DVD.

Soldaat Overzee. Multifilm Batavia. [1948]. Disc 2. Nederlands Indië: Van tropische idylle tot harde realiteit. Hilversum: Netherlands Institute for Sound and Vision, 2011. DVD.

Soldaat Overzee. Multifilm Batavia. [1948]. Disc 3. Einde van Indië: Oorlog in Indonesië. Hilversum: Institute of Sound and Vision/Tijdsbeeld Media, 2011. DVD.

Het Vreemde Leger: 2e politionele actie - Java en Sumatra. Multifilm Batavia. [1949]. Disc 2. Nederlands Indië: Van tropische idylle tot harde realiteit. Hilversum: Netherlands Institute for Sound and Vision, 2011. DVD.

\section{Film}

Indonesia Calling. [1946]. Disc 3. Joris Ivens Wereldcineast. Directed by Joris Ivens. Nijmegen: European Foundation Joris Ivens/CAPI Films, 2008. DVD. 


\title{
3 Post-decolonization: The First 20 Years, 1949-1969
}

\begin{abstract}
While the German occupation of Holland came to dominate post-war Dutch collective memory, the memories of those repatriated from Indonesia suffered from a loss of place. This caused a traumatic rupture in remembering. During the 1950 and early 196os, nostalgic remembering in the works of the likes of Dermoût and Nieuwenhuys, as well as feelings of existential angst and victimhood, contributed to unremembering the reality of decolonization. However, memories of military brutality were present in the stories of Beb Vuyk and in the memoirs and novels of some veterans. Unlike American and Australian historians, few Dutch historians showed much interest in decolonization. Despite some promising historical work in the early 1950s, historians and memoirists ignored the reality of warfare.
\end{abstract}

Keywords: collective memory, unremembering, decolonization, nostalgia, Indonesia, Dutch East Indiess

\section{The Great Unremembering}

With the conflict in Indonesia over, there began decades of relative quiet in the Netherlands. Not only was decolonization unremembered, works of fiction and non-fiction set in post-independence Indonesia received little public recognition. ${ }^{1}$ Marije Goos argues that little attention was given to decolonization in Dutch literary periodicals. ${ }^{2}$ World War Two and the German occupation came to dominate the Dutch need for commemoration. ${ }^{3}$

$1 \quad$ Raben, "De dagen," 27.

2 Goos, Een hard en waakzaam hond, 185-187.

3 Oostindie, Schulte Nordholt and Steijlen, Postkoloniale Monumenten, 11.

Doolan, P.M.M., Collective Memory and the Dutch East Indies. Unremembering Decolonization. Amsterdam: Amsterdam University Press 2021 DOI: 10.5117/9789463728744_CHO3 
Totoks and Indos complained that that no Dutch officials were present when they were liberated from the Japanese prison camps after the Japanese surrender. ${ }^{4}$ Three months after the Japanese surrender, most former camp prisoners were still displaced persons. One and a half years after the Japanese surrender, the first wave of repatriation had yet to be completed. This was partially due to bad preparation on the part of the Dutch authorities. However, many repatriates came to feel that their suffering had been prolonged by corruption and nepotism. ${ }^{5}$ Hundreds of thousands of Dutch citizens eventually left the new republic and received what some later came to remember as a cold welcome in the metropole. ${ }^{6}$ The first Indische self-help organizations were camp reunion committees. These provided ways of speaking about their mistreatment by the Dutch.

Few people in the Netherlands were interested in stories of hardship in Japanese prison camps. There was even less interest in tales of violence during the Bersiap period. The disinterest they faced was similar to the experience of Jews who, when returning from the camps in Eastern Europe or from hiding, found that few wanted to listen to their stories. ${ }^{8}$ Similarly, the soldiers of the Dutch army arrived home to a country that, shamed by defeat, had lost interest. ${ }^{9}$

With the experience of World War Two still fresh, the equalitarian Dutch settled into a collective memory that stressed the sameness of the citizen's experience. The Dutch had suffered under their German neighbour and all had suffered equally. In 1946, respected Dutch historian Jan Romein published an article in which he outlined how the Dutch had reacted to the hardship of World War Two. The Dutch in the East Indies never earned a mention. Even his title, "The Occupation," was singular. ${ }^{10}$ (Similarly, his book-length study of Asian nationalisms, published in Dutch in 1956 and in English in 1962, all but ignored the Indonesian War of Independence. $)^{11}$

The presence of hundreds of thousands of new migrants, most of whom had a skin colour darker then the majority white Dutch, was a reminder of the

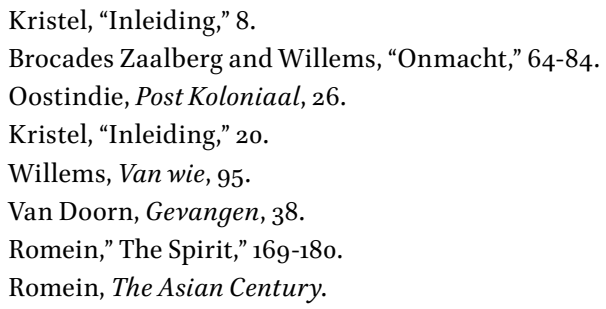


colonial past, but this demographic change worked in a way that reinforced the silence. For some, "repatriation" meant setting foot in metropolitan Holland for the very first time, but 85 per cent of the first wave had been in Holland before. They brought with them a certain amount of cultural capital. Over 9o per cent possessed full Dutch citizenship. They nearly all were Christian, had experience of Dutch values and way of life, and spoke Dutch on a daily basis. A sizable number had been part of the governing elite and had political experience. However, many had had no direct experience of living in the Netherlands for any extended period. The elite had lost their colonial lifestyle and this could not be replicated. Claims for compensation for their loss of wealth and property and claims for back pay for unpaid wages during war years were continually postponed. ${ }^{12}$ For much of the Dutch public, the "Eastern Dutch" were seen as reactionaries - a spoilt, conservative, colonial class. ${ }^{13}$

In order to accelerate assimilation many repatriates decided that colonial rule and the failed "police actions" should not become issues of public debate. ${ }^{14}$ Integration meant, to a large degree, "unlearning what was

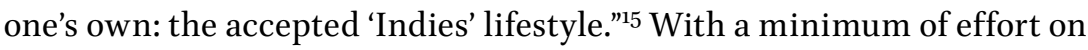
the part of governmental authorities, integration was a success. ${ }^{16}$ By the mid-1950s, they had achieved nearly full employment. ${ }^{17}$ By the late 1960 , repatriates had more or less achieved parity with the home-grown Dutch in the areas of employment, education and within church life, but the cost was that their past had not been integrated into the national memory. ${ }^{18}$ Most Dutch people knew nothing about the distinction between "Indisch" and "Indonesian."."

The price paid for assimilation was the suppression of memory. Recalling his own experience of mixing with Indisch youths in school during the 1950s and 1960s, historian Wim Willems remembers: "No one told stories of the land they had come from, the other war of their parents, the flight to the Netherlands or the family connections with Indonesia."${ }^{20}$

Bosma, Terug, 35-131.

Oostindie, Post Koloniaal, 25-26.

Pattynama, "Herinneringsliteratuur," 215.

Van Leeuwen, "Het Indisch Huis," 278.

Oostindie, Post Koloniaal, 29, 41, 60-61.

Bosma, Terug, 123.

Bosma, Raben and Willems, De Geschiedenis, 68.

Ibid., 139 .

Willems, Van wie, 87. 


\section{Loss}

Indo is the term that came into common usage to refer to Dutch citizens descended from European and Indonesian blood. Since 1828, the criterion in the Dutch East Indies for the right to Dutch citizenship was having a Dutch ancestor ${ }^{21}$ Many European men in the colony lived with a native concubine. Children of these relationships, if recognized by the father, gained citizenship. ${ }^{22}$ The number of mixed marriages between European men and native women (the other way around was almost unheard of) rose from about 13 per cent of European marriages in the late nineteenth century to 27.5 per cent in 1925, tapering off to 20 per cent by 1940 . The number of concubinages approximately equalled the number of mixed marriages in $1940 .{ }^{23}$ Thus, a significant number of Dutch in the colony were mainly descended from locals, but with a (male) white ancestor. Officially, there was no colour bar blocking those of mixed heritage from reaching the highest echelons in society. By the twentieth century, Indos were found at high levels of colonial society. ${ }^{24}$ Discrimination among the elite existed, though some argue that the criterion for social mobility was based on education rather than colour. ${ }^{25}$ However, the period from 1942 to 1949 formed a deep discontinuity in this history. Indisch people went from being engineers of colonial policy, to prisoners of the Japanese, victims of Indonesian nationalists and finally displaced persons in the Netherlands.

Aleida Assmann argues that places "are of prime importance for the construction of cultural memory," because they "embody continuity." ${ }^{26}$ Places bear traces of memory. In the absence of place, memories remain beyond recollection. Memory is triggered by place because that which is remembered happened in place. We say that events take place. Events takes place within a topography that is meaningful and is appropriated by one's identity. A catastrophe for memory ensues when an entire social group, through forced translocation, loses their houses and their cities. They find themselves transported to an alien world that knows nothing of their former homes and cities, and demonstrates disinterest in their experiences and memories. Paul Connerton argues that the house and city street provide powerful loci of memory. The house is a memory device, a 
medium of representation that can be read as a mnemonic system. The furnishings within the home "remind us of the shared history," while the city street forms a web of memories that help to create "a web of public trust." This is taken for granted until war deprives one of one's house. ${ }^{27}$

With the Indisch community forcibly removed to the Netherlands, places that could anchor collective memory had been lost. Major Dutch cities provided constant reminders of colonial times, not only in the form of Indisch shops and restaurants, but also in the form of Indisch buurten or neighbourhoods where all streets were named after islands and cities in the Indonesian archipelago. ${ }^{28}$ These street names were now markers of an absence. The Indisch community found themselves amputated from their past.

Those forced to flee their homeland become, in Salman Rushdie's words, "haunted by some sense of loss," but the writers among them share an "urge to reclaim.." ${ }^{29}$ Among the exiled repatriates, writers like Maria Dermoût, Tjalie Robinson and Rob Nieuwenhuys played leading roles in the "urge to reclaim." Their work provides an example of what Ricoeur described as mourning for loss by psychically prolonging the existence of the loss. ${ }^{30}$

\section{Maria Dermoût: Memory and Nostalgia ${ }^{31}$}

In 1951, a novel was published which reflected one writer's urge to reclaim. Maria Dermoût, born and partly raised in the Dutch East Indies, had left the colony and "repatriated" with her husband to the Netherlands in 1933. The loss of the colony meant that there was no possibility of return for Dermoût, or for the hundreds of thousands of "repatriates." What could be reclaimed was the literary representation of place by means of memory.

Nog pas gisteren (Only yesterday) was her first published book and, although she was 63 years of age at the time of its publication, the vivid memories inscribed in the book create the feeling that it was only yesterday that she had left the former colony and her childhood. The first sentence localizes memory: "On Java, somewhere in Central Java, in between the mountains Lawoe and Wilis, but closer to the side of Lawoe, deep in a walled garden under dark green trees, was a house. ${ }^{32}$ Similarly, her second novel, 
The Ten Thousand Things, from 1955, opens with the following words: "On the island in the Moluccas there were a few gardens left from the great days of spice growing and 'spice parks' - a few only. There had been many, and on this island they had even long ago been called not 'parks' but 'gardens." This is followed by a description of the garden as it looks now, as well "as then," with its "spice trees clustered together, kind with kind, clove with clove, nutmeg with nutmeg, a few high shades trees in between, kanari trees usually, and on the bay-side coconut palms and plane trees to give shelter from the wind." 33

In both works Dermoût emplaces the memory work that follows. The first novel offers an almost cartographical emplacement of the house of memory, the second proceeds by placing the garden of memory on an unidentified Moluccan island, clearly Ambon, and then offers a description of the garden's layout. In this garden there is a broken-down house, and Dermoût asks, "What was left of all the glory?" She tells us that it is memory that remains: "The remembrance of a human being, of something that happened, can remain in a place." ${ }^{34}$ This is why both works are saturated with a strong presence of place - because place holds memory. Furthermore, both novels, in their openings, possess a suggestion of the searching, probing nature of memory work. Only Yesterday, with its vague "somewhere" in Central Java, then its narrowing in to a location between two mountains, then immediately corrected to "but closer to the side of Laroe." The description of the garden in The Ten Thousand Things, contains the phrase "Now, as then," linking the present with the past, like the place of remembering linked with the place of the remembered. Both novels attempt to counteract the painful absence, bringing the past into the Dutch present by representing memory at work.

\section{Memory, Identity, Place}

Marc Auge has written that ethnic groups seek identity through the demarcation of soil, creating a myth of a society "anchored since time immemorial in the permanence of an intact soil" and that the group "is established, assembled and united by the identity of place." When the territory can no longer be read as a marker of identity, the group finds itself, wherever it might be, in a non-place. When a people are forced to migrate, then their place becomes a place of memory. ${ }^{35}$ The Indisch community had diverse 
origins, but, it was the Dutch East Indies that provided the place of their establishment, assemblage and unity, their "intact soil." By the 1950s, this homeland no longer existed, neither spatially nor temporally, and they found themselves inhabiting a non-place. This was of great significance in Dermoût's attempts to emplace her memories in thick descriptions of the landscapes of Ambon and Java. Dermoût was exiled from her territory and amputated from her place; her works attempted to reclaim it by means of the evocation of a place of memory.

\section{Only Yesterday}

Only Yesterday tells the story of twelve-year-old Riek, an only child. Her childhood is near idyllic, with a beautiful house, servants, a loving native baboe or nanny who sleeps on a mat by her bed. She is surrounded by stories that keep her awake at night..$^{36}$ Sleep arrives only with forgetfulness, a metaphor for the Dutch postcolonial situation in which repatriates will only achieve contentment though forgetting. Riek's life is surrounded by secrets. Violence is only slightly out of sight. The sultan wants to buy a particular beautiful boy "to play with," despite the fact that he has over a hundred others (16). Riek is afraid of Arabs (17). Aunt Nancy reads her fairy stories but breaks down in tears because of homesickness (30-31). Everyone seems to have secrets, including Riek, who has spied married Nancy locked in an embrace with bachelor "Uncle Fred" (35). Riek and her mother visit an old, wise man in the mountains; he knows about plants and herbs, astrology and the ancient kingdoms of Java (38-41). When the old man dies, Riek feels the loss deeply, not just the loss of the old man, but also his garden, the mountains where he lived, the old Buddhist temples and Hindu gods (46). It is a premonition of a loss to come.

Riek's childhood is threatened as the native population grows restless and burns sugar plantations. Her family are gripped by fear. "Why do they want to murder us?," the little girl wonders (49). The burnings stop, but a servant is killed and Riek encounters the reality of murder $\left(5^{0-} 5^{2}\right)$. By the end of the novel Nancy becomes a persona non grata, Fred goes into exile and dies and Fred's devoted manservant, Boeyoeng, overwhelmed with sadness, departs for his home in Sumatra. Riek's baboe, Oerip, leaves after years of devoted service. Nothing remains, Dermoût seems to be saying. One morning, Riek's father informs her that she is to be sent to the Netherlands to attend secondary school. She thinks to herself "dying and going away, it's the same thing" (84). But, before she leaves, she tries to take it all in: 
"There was so much: besides all the people, also the other things that she loved - her place on earth until now. [...] All of the mountains, the entire range - she knew them all out of her head. Java and her blue mountains, and the surrounding blue sea" (85). The novel ends with the words: "She needed time to lose it all" (85).

Dermoût had left the Dutch East Indies before decolonization. The memories that she recalls are of a time further back, in her own childhood in the late nineteenth and early twentieth centuries. However, her work served as a metaphor for decolonization, which explains its popularity among the displaced Indisch population. As Pattynama points out, the ending, "foreshadows the national loss of the Indies." 37 Thick descriptions of nature, sounds, houses and food combine to retrieve the lost and bring it into the present. It is in the periphery of the story we glimpse allusions to colonial cruelty: "When you strike, you must hit hard"38; the oppression of the faceless peasants and the fear of their colonial masters who prepare for revolt (48); the rigid class system (36).

Decolonization meant that the place that had provided the group with an identity had been lost. The European rule of Indonesia had passed, just like the rule of the earlier Buddhist and Hindu kingdoms. The memory of this loss is fresh and painful but it too will pass, until forgetfulness is achieved. In the meantime, we have memory. However, the novel unremembers the historical causes of the loss and no reasons are given as to why the idyll had to end.

\section{The Ten Thousand Things}

The Ten Thousand Things appeared in 1955. We have seen how it opens with the emplacement of the story within a garden on an island in the Moluccas, the so-called Spice Islands. This story is told in sections or frames. However, the English translation reworked these frames, to Dermoût's satisfaction, and thereby "made visible the deeply hidden foundation of the narrative framing." 39 The titles emphasized the importance of place for the localization of memory: "The Island," "At the Inner Bay," "At the Outer Bay," and again "The Island." The main character, Felicia, is referred to as "the lady of the Small Garden," rooting her in a sense of place. In the second frame, "At the Inner Bay," it is not so much the lady of the Small Garden but, as Olf Praamstra 
has pointed out, it is the garden itself who is the main character. ${ }^{40}$ This rootedness in place is an example of Auge's claim that a group's identity is united through the identity of place. ${ }^{41}$

The Ten Thousand Things is set in Ambon just before World War One. Yet, it is as if Dermoût still dwelled deep within that world. She writes that inanimate objects, manmade or natural, hold memories of the distant past. ${ }^{42}$ Songs are vehicles of memory (13). Recitation enhances memory $(36,51)$. Narratives operate as a form of ars memoria (80). Memory is embodied, like when one picks up an implement and the hand remembers (108). Memory is outsourced to written notes (156). Photography acts as a prosthetic memory (160-162). In this world of remembering, forgetting is like a disease, as when a professor complains about his memory and wonders if he has malaria (176). The slave bell is rung every time a boat enters or leaves the bay, but sometimes it is forgotten (7). Stones are erected as markers of everlasting remembrance, but the graves lie forgotten (10-11). A grandmother warns her grandchild: "[F]orgetting is not good" (87).

Each frame narrates a story of violent loss. Life amidst the magnificent nature is undermined through dark undercurrents. This sense of loss, had been experienced personally by Dermout. The lady of the Small Garden is the fifth generation to own the garden; "her son would have been the sixth generation," but her son is murdered and she is the end of the line (6). Dermoût, too, is descended on her father's side from a family that had lived in the East Indies for generations. ${ }^{43}$ Her son, too, had died violently, in a Japanese prison camp. Like the lady of the Small Garden, "she knew pain, inside and outside - and what is there to still pain?"44 Like Riek in Only Yesterday, Dermoût was raised on a sugar estate on Java within sight of Mount Lawoe. For years, she had lived with her husband in the Moluccas, like Felicia, the lady of the Small Garden. ${ }^{45}$

\section{Nostalgia}

To some extent, Dermoût's two novels are works of nostalgia - evoking an aching memory that is a bittersweet longing for something impossible to retrieve. Dermoût expresses the dominant mode of memory, nostalgia, experienced by most forced migrants. For the first generation of Indisch

\footnotetext{
40 Praamstra, "A World," 57.

41 Auge, Non-Places, 37.

42 Dermoût, The Ten Thousand, 5, 50.

43 Nieuwenhuys, Mirror of the Indies, 256.

44 Dermoût, The Ten Thousand, 199.

45 Nieuwenhuys, Mirror of the Indies, 255-256.
} 
repatriates, according to Pattynama (herself a child of Indisch repatriates), "there was no deeper emotion than the feeling of loss of and separation from the East Indies and this feeling shaped them into a Dutch mnemonic culture. ${ }^{m 6}$ Dermoût's works package memories in a powerful manner, sure to impact those suffering from a melancholy brought about by loss. Zofia Rosinska has described the dominant emotion among emigrant communities when confronted with the impossibility of return as being melancholy and that this melancholy becomes closely tied to the group's identity and memory, supporting community forming and creating a bond by means of collective recollecting. ${ }^{47}$ Dermoût's work, furthermore, was an example of what Ricoeur called "repetition-memory," the first, but incomplete step in working through the traumatic memory. ${ }^{48}$

Anthropologist Renato Rosaldo warns against a so-called innocent imperial nostalgia that, in effect, captures the imagination while concealing its "complicity with often brutal domination."49 This echoes Rushdie's anger against the nostalgia of "Raj fiction" in Britain during the 1980 s. $^{5^{\circ}}$ Such representations of colonial times rely on an Orientalist "archive of information. ${ }^{11}$ However, Pattynama argues that the nostalgia of the likes of Dermoût was not reactionary, but a vehicle for emotions that otherwise would not have been permitted public expression in the Dutch culture of memory during the 1950s, where colonial guilt and shame dominated..$^{2}$ Furthermore, she claims that nostalgia is not a simple affair and that there are different forms of nostalgia, serving different goals for different groups. 53

Recent research supports Pattynama's argument. Nostalgia is a complicated form of memory representation. Walder argues that the "suspicion and mistrust with which it has been viewed by progressives [...] reflects a lack of understanding. ${ }^{54}$ Likewise, while examining the pervasive presence of imperial nostalgia among the formerly colonized, Bissell warns, "any attempt to cast colonial nostalgia as purely retrograde or reactionary seems dubious at best." 55 For instance, Rosaldo's claim that nostalgia as

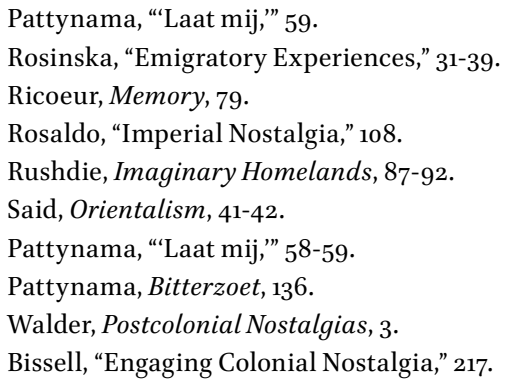


a concept is a Eurocentric one ${ }^{56}$ is disputed by findings in psychology, where experimental results in British tests have been replicated in Chinese findings. ${ }^{77}$ This implies that nostalgia is universal. Indeed, psychologists today see nostalgia as a resource that "strengthens social connectedness and belongingness, partially ameliorating the harmful repercussions of loneliness, ${ }^{n 8}$ something that the displaced Indisch community needed. Furthermore, nostalgia is considered "a fundamental human strength" that helps imbue life with meaning. ${ }^{59}$ No doubt, the capacity to strengthen social connectedness and ameliorate feelings of loneliness as well as the capacity to foster a new purpose or meaning gave nostalgia its power, and hence its hold over the displaced Indisch community. Dermoût's works thereby inscribed a form of cultural remembering that helped create a collective identity among a mnemonic community, where the binding element was the nostalgic remembering of loss.

But Dermoût's novels also operated as a screen upon which unremembering took place. They appeared at a crucial time - with the metropole still recovering from German occupation, relations between the former colonial power and the former colony deteriorating, and thousands of repatriates still arriving in the Netherlands. As we know from Halbwachs, the mind does not remember alone but remembers "under the pressure of society," that is, memories are constructed "on the basis of the present." ${ }^{\text {6o }}$ In the Dutch present, Dermoût's work provided a recipe for surviving a sense of loss by helping to build a nostalgic community.

In the final section of The Ten Thousand Things, the lady of the Small Garden sits alone on the beach, under the moon, as she does every year, and remembers all those who have been murdered on the island. In this battle against forgetfulness, she tries to bring each to mind, until she enters a mystical reverie and contemplates the murderers "without hatred now." ${ }^{\text {"61 }}$ In her mystical trance she experiences how all things, people, animals, stones and sea, are linked together and flow into each other in a way that she could not understand, but understanding "was not needed, wasn't possible, she had seen it - for one moment over the moonlit water" (208).

In this acceptance of the absence of understanding, Dermoût represents the loss of the Indies as a loss that can be experienced, but not understood.

56 Rosaldo, "Imperial Nostalgia," 108-109.

57 Zhou et al., "Counteracting Loneliness," 1028.

58 Ibid.

59 Sedikides, et al., "Nostalgia," 306-307.

6 o Halbwachs, On Collective, 57; 40.

61 Dermoût, The Ten Thousand, 206. 
It will be accepted by forgiving, and by erasing the need for understanding. The lady of the Small Garden is brought out of her reverie when two servants call her to come to bed and to drink coffee: "The lady of the Small Garden whose name was Felicia stood up from her chair obediently and [...] went with them [...] to drink her cup of coffee, and try again to go on living" (208). So too, the Indisch community had to leave their beautiful archipelago and in their new home would have to "try to go on living." It is significant that in this final sentence, Dermoût refers to the lady of the Small Garden by her name. Felicia means "happy," and it is the acceptance of her loss, without the need for understanding or explanations, that makes her, finally, happy.

Dermoût's work represents decolonization as a rupture with the past, the incomprehensible loss of one's place. It brings with it the challenge to remember, to accept and to go on living. But this act of remembering, as an instrument of unremembering, did nothing to help explore why, suddenly (seemingly), in the years from 1945 to 1949, the native population of Indonesia had turned against their European (Indisch) leaders and the Indisch community had discovered themselves to be strangers in the place they considered their own. Nostalgic representations and collective memories of loss, by reinforcing the dwelling on pain, impeded attempts to remember the roots of the trauma.

\section{Cultural Appropriation}

Leading Indisch intellectuals have claimed Dermoût as an Indisch writer, and therefore not really European or Dutch at all. ${ }^{62}$ They could not be more wrong. True, Dermoût's novels reflect a deep interest in the culture, beliefs and lifestyles of the peoples of Indonesia. The Ten Thousand Things is influenced by Chinese thought and the narrative is animated with concepts taken from Moluccan animist folklore. ${ }^{63}$ Dermoût's writings combine her own memories with ancient Javanese epics. ${ }^{64}$ Dermoût presents the reader with an "Eastern view of life" constructed from Taoist, Buddhist, Christian and Moluccan beliefs. ${ }^{6} 5$

However, the appropriation of non-Western ideas, motifs and narratives was a common feature of European modernism. Orientalist fantasies were a recurring element in European popular literature and the East Indies as

\footnotetext{
62 For instance, Tjalie Robinson to Maria Dermoût, 16 November 1955, in Robinson, Schrijven met je vuisten, 256 .

63 Thiam, "Een wereld vol geesten," 81.

64 Bogaerts, "Tussen tekst," 52-54, passim.

65 Praamstra, "Afscheid," 194-197.
} 
the Dutch Orient was present in Dutch literature. It is within the context of this European tradition, enabled by the adventure of empire and the appropriation of non-Western narrative, characters and ideas, that we must place the work of Dermoût.

At the time that she was working on her novels she was also reading widely. We find her seriously engaged with Dutch poets J.C. Bloem, Marsman and Roland Holst, but also Wordsworth, Matthew Arnold, Auden, Yeats, Emily Dickinson, as well as Pound, Tennyson and T.S. Eliot. ${ }^{66}$ The latter deeply influenced her in his approach to love and death and the attempt to find harmony in life. ${ }^{67}$ His work supplied her with the epigraph to Only Yesterday. She was inspired by a poem from the modernist Vita SackvilleWest. ${ }^{68}$ The novelists that she read at this time included those by Kipling, Camus and Forster. ${ }^{69}$ She described $A$ Passage to India as "one of the most beautiful [books] that I know."70

Dermoût's first collection of short stories, published in 1954, was based on a Javanese Hindu epic (in Dutch translation) and contains much exoticism. However, she marked her literary modernism by including a quote from British writer Sacheverell Sitwell in this collection, and, as Salverda argues, below the surface of her prose lies her literary technical modernism..$^{71}$ Dermoût combined Eastern oral narrative techniques with sophisticated Western literary tropes, making The Ten Thousand Things typical of twentieth-century Western literature. ${ }^{72}$ Houtzager concludes that Nieuwenhuys' obsession with squeezing Dermoût into an Asian tradition blinded him to the modern, Western aspects of her novel. ${ }^{33}$ Praamstra admits that Dermoût's use of Moluccan motifs in The Ten Thousand Things was taken directly from the works of the great seventeenth-century German naturalist Rumphius. ${ }^{74}$

One could counter by claiming that The Ten Thousand Things is permeated by "Eastern" thought and Asian motifs. After all, Tjalie Robinson pointed out that the epigraph of The Ten Thousand Things came directly from Chinese philosopher Ts'en Shen. ${ }^{75}$ The epigraph reads: "When the ten thousand

66 Van der Woude, Maria, 158-162; Freriks, Geheim, 216.

67 Freriks, Geheim, 190.

68 Ibid., 215.

69 Van der Woude, Maria, 145-162.

70 Freriks, Geheim, 205.

71 Salverda, "De dingen," 221-222.

72 Houtzager, "Maria," $75-87$.

73 Ibid., 87 .

74 Praamstra, "Afscheid," 198-199.

75 Van der Woude, Maria, 184. 
things have been seen in their unity, we return to the beginning and remain where we have always been." Additionally, Dermoût had been intensively reading Chinese poems - but these "Poems of Departure" were Ezra Pound's translations. ${ }^{76}$ She also read the old Chinese classic Monkey, in Arthur Waley's new translation, but only because it had been recommended in The Perennial Philosophy, a work by Aldous Huxley. ${ }^{77}$ Huxley influenced her profoundly. His claim that oneness "is the ground and principle of all multiplicity," summarizes Dermoût's philosophy in The Ten Thousand Things, and his quotation from the ancient Neo-Platonist, Plotinus, seems to have influenced the ending of Dermoût's book. ${ }^{78}$ Furthermore, we find Huxley quoting the following words from an ancient Chinese text: "When the Ten Thousand things are viewed in their oneness, we return to the Origin and remain where we have always been." ${ }^{\prime 9}$ In a letter to her German translator, Dermoût admitted that she had taken this quote for the epigraph [and title] to her second novel, not from Ts'en Shen, but from Huxley's The Perennial Philosophy. ${ }^{80}$

Contrary to what Robinson thought, having an Asian epigraph to The Ten Thousand Things did not demonstrate that Dermoût was Indisch as opposed to Dutch. Neither did it prove that she had read the Tao Te Ching; rather it proved she had read Aldous Huxley. It was an indication of how she was part of a general European movement that was intrigued, in an Orientalist manner, with aspects of the cultures of colonized people. The irony is that Dermoût herself regularly denied the label "Indisch." ${ }^{\prime 1}$

\section{The Colonial Point of View}

Demoût's books could only have been written from the point of view of Dutch colonial power. To claim otherwise is to deny the asymmetrical nature of power that characterized relationships during imperialism. It is the privilege of the colonial power to tell its own story. Furthermore, it is the privilege of colonial power to tell the other's story as well, in as much as it touches or overlaps with the story of its own power, like when servants enter the colonial narrative. As Said articulates it: "The power to narrate,

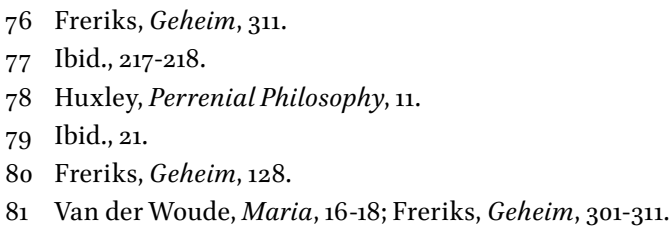


or to block other narratives from forming and emerging, is very important to culture and imperialism." ${ }^{82}$

We never read of any of Dermoût's main characters abusing their power. They are horrified by the brutality of some colonials. They study the ancient cultures of Java and respect native beliefs. In The Ten Thousand Things, the lady of the Small Garden has, it seems, gone native, so to speak, "in her sarong and simple white cotton jacket [...] in bare feet on strong leather sandals" and everyone on the island likes her. ${ }^{83}$ But, Said reminds us that "the rhetoric of power all too easily produces an illusion of benevolence when deployed in an imperial setting." ${ }^{84}$ During the first three decades of the twentieth century, while Dermoût was living in the colony, the Dutch colonial government operated under a policy that was meant to be benevolent, aiming to develop the social and economic position of the native, yet this was also the time of the birth of the first Indonesian nationalist movements. The response of the colonial government was to limit political and civil freedoms, detaining suspects for years without charges. By the early 1930s, around the time that Dermoût would leave the East Indies, the leading spokespeople for Indonesian nationalism had been interned in prison camps. In such a system, when criticism is silenced, it is easy to be convinced of one's benevolence.

Much is made of the physical descriptions of the owners of the Small Garden. We learn that the grandmother "was a skinny little woman with a dark complexion, dark hair and dark eyes." ${ }^{85}$ We are told that Felicia, the lady of the Small Garden, when a young woman, was "small and strong with a round boyish face, springy brown hair, dark attentive eyes" (39), and her son, Himpies, has "warm brown eyes with spots" (90). There is no doubt that the family is European and the native people refer to the lady of the Small garden as "the little white woman" (89). But the stress on dark complexion and dark eyes seems to indicate that they are of mixed blood or Indos. This is supported by the expression "She herself belonged to the island" (17), meaning, probably, that she is descended from a native Moluccan. Praamstra goes as far as to say that the grandmother was Ambonese. ${ }^{86} \mathrm{He}$ agrees that the strong sense of place in the novel, is a strategic deployment that asserts ownership and colonial hegemony. ${ }^{87}$ Within the garden, there exists a hybrid society where totoks, Indos, natives - masters as well as

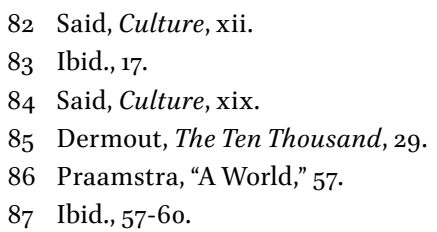


servants - come together in a peaceful, privileged place where respect and toleration are the order of the day. In such a place, hegemony is complete, power remains invisible. A good example is the final lines of the novel, already quoted, when the servants call Felicia to come to bed and to drink her cup of coffee. We are told that she rises from her chair "obediently." She obeys her servants. However, this relationship is not based on equality. It is her prerogative to obey, or disobey. In fact, the hybrid society that she has created on her property can only exit due to the laws implemented by the colonial government. If the colonial authority would cease to exist, the idyllic micro-society would be doomed. What passes unmentioned in Dermoût's account, but is pointed out by Praamstra, is that the Small Garden in which European and Asian meet each other with mutual respect is in a space that once was "violently taken away from the original population." ${ }^{88}$ Dermoût's point of view is that of a Dutch colonialist, backed by the apparatus of power which, though kept out of sight, nevertheless, surrounds the narratives and enables their telling.

Dermoût does not entirely ignore the ugly side of colonialism. As we have seen, in Only Yesterday the peasants burn down the sugar fields and the planters are gripped by fear. Prisoners are beaten. In The Ten Thousand Things, we are reminded of the former existence of slavery: "My father said once - everyone had slaves, those were the years of slaves, that was the evil of the time, my father said. Every time has its own evil." ${ }^{89}$ This passage seems to trivialize the ugliness of slavery as a system. To accept that slavery is bad, on the one hand, and on the other hand, to accord that every era has something bad, trivializes. In addition, if this goes for slavery, then it goes for colonialism as well. Colonialism has its ugly side, but every era has its own form of evil. The important thing is to be good within the system. This interpretation is supported by the words of Maria Dermoût herself. In an interview with Robinson, she voiced her dislike of the label "colonial family," explaining, "East and West were not a problem. We were spoon-fed the idea that "Every person has equal worth."'9o

Regardless of how much she disliked the term "colonial," we learn that the family of the Small Garden was wealthy, owning a big house with a spice plantation but also a house in the town, which they rented out. ${ }^{11}$ As a child, the lady of the Small Garden and her parents went to live in the 
Netherlands and she returned as a young mother (38-39). In turn, she sends her son Himpies to the Netherlands to be educated and to become a surgeon (85). These are privileges made possible by the colonial system. However integrated the family becomes into the world of the East, they retain the advantages that Western hegemony bestows. Yet the trappings of power that ensure this asymmetrical relationship between colonizer and colonized remain almost invisible in Dermoût's representations of colonialism. The novels include incidents of violence, but they are excesses, not symptoms of some deeper, political malaise.

\section{Silencing Other Stories}

Dermoût tells us that the land had been in the family's possession for five generations, but she silences the brutality of its appropriation. She informs us of the earlier existence of slavery, but silences the fact that the Netherlands was a major player in the global slave trade. She tells us that Riek's parents were sugar planters, but silences the fact that the sweetness and exploitation went hand in hand. These are examples of what anthropologist Michel-Rolph Trouillot calls "formulas of erasure." ${ }^{2}$ He has written that "planters and managers could not fully deny resistance, but they tried to provide reassuring certitudes by trivializing all its manifestations. Resistance did not exist as a global phenomenon. Rather each case of unmistakable defiance, each possible instance of resistance was treated separately and drained of its political content."93 Trouillot was writing of eighteenth-century Haiti, but his words apply equally to Dutch colonial society.

Let us look at three examples from The Ten Thousand Things. Firstly, we learn that during the age of slavery, the first spice growers had employed a Balinese slave girl as the nurse for their three daughters. One day the daughters were all poisoned and the slave was accused of murder and tortured until she was crippled, but she refused to confess and was eventually released. ${ }^{94}$ The tragic killing of the little girls is a motif that returns. They are remembered. The slave is never referred to again.

Secondly, when Himpies becomes an officer in the colonial army he is sent on an expedition - "just a small expedition" - to the island of Ceram, to make a "show of strength for the Mountain Alfuras who had become a nuisance" (97). Note the use of the euphemism "small expedition." We are not given to consider that Dutch colonial authority might have been a 
nuisance for the Mountain Alfuras. During the "expedition," Himpies is shot and killed by a single arrow. The killing is described as random, senseless, memorable only for the heroic efforts of his comrades attempting to save the young soldier (106-107). The motivations of the Mountain Alfuras are passed over in silence.

The third example concerns a Scottish professor who undertakes a tour of the islands with his Javanese assistant, Suprapto. The professor is murdered by machete-wielding Binongkos or sea tramps (183-184). We learn a great deal about the professor, his family, his naive enthusiasm, occasional wisdom and his positive philosophy of life, which seems to echo Dermoût's own (168). He dreams of a hybrid space where East and West can be equals. But Dermoût only tells us of the Binongkos that "they were a strange kind of people, speaking a language no one understood; and no one wanted to have anything to do with them" (173). No attempt is made to understand their point of view. They are dressed "in rags, almost naked" with "small, squat bodies" and "black, stupid eyes staring straight ahead" armed with machetes (173). They enter the story to murder and rob the professor. The rest is silence.

Dermoût's novels, widely admired in the Indisch community and beyond, staked a claim to a territory in the past that provided a marker of identity. They helped to construct a collective memory of nostalgia, a melancholy acceptance of irreparable loss, the loss of that place that she had described with loving detail, a benevolent tropical home that had given the group its identity. That place would remain a marker of identity only in as much as it would be remembered. While her memory work served to create a mnemonic community based on nostalgic remembering, Dermoût's silencing of Indonesian aspirations inadvertently served to unremember the reality of decolonization.

\section{Tjalie Robinson: Building Memory for a Hybrid People}

\section{Hybidity}

Benedict Anderson characterized a nation as being an "imagined political community" that is "inherently limited and sovereign." "95 For people of mixed colonial descent, such as the Indo, the problem lay in negotiating a position between or within imagined communities. Homi Bhabha has problematized what he refers to as "the irresolvable, borderline culture of hybridity." 96 Edward Said is a case in point: raised an Orthodox Christian Palestinian 
with American nationality, he was born in Jerusalem, educated in Cairo (attending an English primary school and American secondary school) and gained renown as a professor at an American university. It is not surprising to learn from Said that "the overriding sensation I had was always being out of place." 97 This feeling of not quite fitting in, of in-betweenness, animated Said's work while also lending it strength. Being able to identify with both sides of the "imperial divide" allows the hybrid to feel that he or she belongs to more than one group, more than one history. ${ }^{8}$ This challenges the myth of purity. The difficulties of cultural hybridity are compounded when it stems from the unequal relationships of colonialism, developing from, to use Fanon's words, "the arsenal of complexes that has been developed by the colonial environment." 99

In 1954 there arrived on Dutch shores a repatriate who would come to define, during the following decades, what it meant to be an Indo and whose energetic activities came to shape Indo collective memory: he went by many names but became most well known as Tjalie Robinson. Long before Rushdie, Bhabha or Said, Robinson became a cultural translator negotiating a space between cultures. He recognized that the Netherlands and the Republic of Indonesia had positioned the Indo on the margins of the East-West encounter, but argued that the Indo was not simply a mix of European and Asian, but a separate cultural-historical category. Anticipating the views of postcolonialists, Robinson claimed that what made the Indo unique was not his or her marginalization on the periphery of East and West, but the fact that Indo identity was shaped by living in more than one culture.

Robinson quickly became the leading fighter for the Indisch community in the Netherlands, struggling to maintain Indisch culture and confronting an assimilation that would mean disappearance. ${ }^{100} \mathrm{He}$ wrote soon after his repatriation that "there is no possibility of returning home. [...] [A] Dutchman exiled in the Netherlands [...] is not the problem of Tjalie only, but of thousands and tens of thousands more tropical Dutchmen, [...] a conflict of the spirit." ${ }^{101}$ With no return possible, the temptation was to find support in nostalgia. Robinson set himself the task to save the Indo from nostalgia and from assimilation. The way to ensure that the culture of the Indo would not disappear, was through the construction of a collective memory.

97 Said, Out of Place, 3.

98 Said, Culture, xxx-xxxi.

99 Fanon, Black Skin, 19.

100 Passman, "Van Tjalie," 8-9.

101 Robinson, Een land, 148. 
Robinson's work focused on remembering, yet ironically it contributed to unremembering decolonization. His work consisted of three strands. Firstly, his prime concern was to create a new, hybrid culture within the Indisch community. Secondly, he intended to salvage the old Indisch way of life in order to construct a collective memory that would form the basis of this new, hybrid identity. Thirdly, this emphasis on recalling the old Indisch way of life would mean unremembering the traumatic years from 1942 to 1949, the period of Japanese occupation and decolonization; remembering colonialism necessitated unremembering decolonization.

\section{A Flâneur in Batavia}

Tjalie Robinson was a pen name of Jan Boon. Born in the Dutch city of Nijmegen in 1911 to a totok father and Indo mother, he moved to the Dutch East Indies when just three months old. From the mid-193os he worked as a journalist. Biographer Wim Willems comments that even early in his career, Robinson was motivated by the idealistic goal of nurturing an Indisch consciousness. ${ }^{102}$ During the Japanese occupation, he was imprisoned in the Tjimahi internment camp, where he became editor-in-chief, as well as contributor and cartoonist, of a weekly paper published by the prisoners. He was later transferred to Changi, in Singapore, and finally Johore, on the Malay Peninsula, where he was put to work as a forced labourer. During the decolonization war he was appointed editor-in-chief of a magazine for Dutch military personnel, where he wrote articles using pseudonyms. ${ }^{103}$

In 1948 Robinson became editor-in-chief of the daily Nieuwe Courant. In a series of articles he called for young Europeans and Indonesians to create a new type of society, in which the double identity of the in-between would not be questioned. That same year he became involved in Orientatie (Orientation), a periodical supporting Indonesian independence, highlighting nationalist Indonesian and Indisch authors. Here, for the first time, he used the pen names by which he would become famous, Vincent Mahieu and Tjalie Robinson. ${ }^{104}$

Inspired by the mestizo culture of Latin America, he embarked on the task of being the chronicler of this hybrid culture. Thanks to a series of essays published in Indonesia, in the newspapers Nieuwsgier and Het Vrije Volk in the early 1950s, the name Robinson became a renowned, especially when a selection of the essays were published in two volumes in Bandung in

102 Willems, Tjalie Robinson, 121.

103 Ibid., 147-191.

104 Ibid., 217. 
$195^{2}$ and 1954, under the title Piekerans van een straatslijper (Ruminations of a flâneur). ${ }^{105}$

Robinson recognized that an exiled people lose the loci of their memories and are in danger of losing their identity. Many of these essays find Robertson wandering through the romantic city of his memory, pre-war Batavia. In his attempt to explain to himself and his contemporaries who he is, who they are, he reclaimed the memory of what it meant to grow up in Indisch culture. What that meant must be found in the pre-war period because, as he says, the Dutch East Indies "has been dead since 1939." ${ }^{106}$ Consequently, his memory work leaves the period from 1939 to 1949 unremembered. The war is rarely referred to. When it is mentioned, decolonization is represented as a rupture that changed Indisch historical development. So Robinson's is a literature of salvaging what can be salvaged - the cultural memory, with its smells, tastes and colours, so that, equipped with this memory, the Indisch community can move on.

The original articles appeared in newspapers between $195^{1}$ and 1955 . But few readers preserve newspaper clippings. Memory becomes stabilized through revisiting, and few readers revisit essays in their original medium. Even Robinson himself, when he eventually immigrated to the Netherlands in 1954, no longer had access to the original essays. Instead, it was the selections that appeared in the two-volume Piekerans van een straatslijper that would be read and reread over the following decades. Generations of Indo-Dutch citizens grew up with these stories. ${ }^{107}$

\section{The Forgotten Essays}

While researching his biography of Robinson, Wim Willems discovered copies of the original articles of the entire Piekerans series on microfilm. In 2011 he published a selection that had been forgotten. Once again we find Robinson grappling with the dilemma of the in-between. He describes himself as someone with Nietzsche in his head, Mozart in his ears, Malraux in his heart, but also "mosquitoes at my calves and the smell of shrimp paste in my nose. ${ }^{108} \mathrm{He}$ refuses to reject European or Indonesian culture: "I simply want the best of Indonesia and the best of Paris. That's all" (146).

But the selection also contains essays based on Robinson's memories of the Japanese occupation and the subsequent war of decolonization. In one,

105 Ibid., 27 and 227.

106 Robinson, Piekerans, vol. 2, 102.

107 Willems, Tjalie Robinson, 9.

108 Robinson, Kind, 145. 
he gives an account of when he and a comrade sneaked out of the Japanese camp to raid a nearby fruit garden. Robinson unexpectedly finds himself confronted by a guard, who turns out to be Javanese. He is frozen by fear, but then: "It was as if we recognized each other. [...] I saw the homesickness in his eyes." Having stood in silence, the guard slowly turns and returns to his post (124). Back in camp Robinson and his comrade do not share their plunder with others, but devour the bananas and jackfruit, ignoring the greedy eyes and smacking lips of their starving fellow prisoners (125). "We were all stone hard," he states (126).

These confessional essays include dark reflections on what the torturous pain of persistent hunger does to a human being, based on his own experience in Jahore in 1945 (128). He recalls how he and a comrade stole cassava and, back in the camp, ate it themselves, ignoring the pleading looks of their fellow prisoners. He writes: "I am a pig, I am a pig” (130). He tells of privileged gentlemen reduced to eating leafs, grass, snakes and rooting in the rubbish bins for fish heads and peels (131). He tells of men reduced to beasts, sucking the empty eye sockets of a dog's head, and concludes that as "civilized human Europeans, [...] we are deeply ashamed" (130). Significantly, he describes how he saw this same sort of starvation and depravity, during the decolonization war in 1949, witnessing masses of naked, starving Javanese standing motionless, their eyes dull, their skin stretched over their bones (127). When he throws them a banana they react "like wild dogs," striking out, scratching, kicking, screaming as they fight for the banana. They were like beasts, he says. They remind him that he once was a beast (128).

Robinson had experienced life at its most debased, an experience that filled him with shame. Willems argues that this convinced Robinson of the negative aspects of nationalism, the narrow choice between Indonesia and the Netherlands, and convinced him that the right choice was a combination of what was worthwhile in both civilizations. ${ }^{109}$ In his personal life, Robinson seldom spoke to his family members about his war experiences. ${ }^{110}$ In one essay we find the rhetorical question: "And who likes to think back to times of need?"111 The Japanese experience, and the loss of a homeland resulting from decolonization, for Robinson, was hard to think back on. But he did undertake this memory work. Yet, when his essays appeared in book form, those that dealt with the Japanese occupation and decolonization were not selected. It was Robinson himself who made the selection for inclusion

109 Willems, Tjalie Robinson, 166-167.

110 Ibid., 174.

111 Robinson, Kind, 127. 
in Piekerans van een straatslijper. He decided to exclude these pieces that revealed "I am a pig."

It was hard to represent the Indo as anything but a victim of decolonization. But focusing on victimhood was not going to be a useful tool in building a hybrid culture. For that, Robinson needed the memory of the Indisch past, one that had continuity and was heroic. The experience of 1942-1949 formed a traumatic rupture in history. There was nothing there to be salvaged. These were the years characterized by the sense that "we are deeply ashamed." For the dislocated Indo, decolonization needed to be unremembered in order to salvage the memory of the hybrid culture of pre-decolonization times.

\section{Enter Vincent Mahieu}

But Jan Boon was a complicated human being, hard to pin down, as evidenced by his use of pseudonyms. The February 1948 issue of Orientatie had seen the birth of Tjalie Robinson, fiery journalist and gifted essayist. The following month saw the debut of Vincent Mahieu, storyteller and author of literary fiction. Boon had found another outlet for his creative energy.

Mahieu wrote vividly about events during decolonization. Yet, unlike Tjalie Robinson, he is today almost forgotten, both within the Indisch community and among the Dutch reading public at large. When his collected works were published in 1992, Mahieu was described as "a great writer."112 Near the end of the twentieth century, Het Parool published a hundred declarations of love to the most beautiful books of the century. Mahieu's work was included. But, Allu Lansu added that it was a scandal that this writer became all but unknown. ${ }^{113}$ The disappearance of Vincent Mahieu forms a case study in unremembering decolonization.

Mahieu's first published short story, "Op zoek naar eten" ("Looking for food"), appeared in Orientatie. ${ }^{114}$ We immediately recognize the theme. Four men, prisoners of the Japanese, maddened by hunger, come across a cat and try, but fail, to beat it to death in order to eat it. A second story, called "Sonja," explores the strange friendship between two prisoners of the Japanese, Marcel Blondeau and Rudi. The name, "Marcel Blondeau" echoes "Vincent Mahieu" and the character shares similarities with Boon/Robinson/ Mahieu - a born storyteller, footballer, boxer, and motorcyclist. ${ }^{115}$ Although

112 Willem Kuipers, "Met een been in het koele water van de kali," De Volkskrant, 13 March 1992.

113 Allu Lansu, "De Mooiste: Vincent Mahieu," Het Parool, 28 August 1998.

114 Mahieu, Verzameld werk, 431-434.

115 Ibid., 355 . 
the theme of the story is the relationship between the two men, this takes place against a vivid background of depravity and Japanese cruelty.

Like the example of Robinson's Piekerans series, occasional publications in magazines seldom become stabilizers of collective memory unless they appear in book format or are remediated in film or television or in another media. Mahieu did have an anthology of his work appear in Indonesia in 1956, and this collection, Tjeis, appeared in the Netherlands in 1958. Dutch critics were unanimous in their praise. The collection was chosen as a "Book of the Month," garnered literary awards in Belgium and the Netherlands and in 1960 the author was presented with the Novella Prize of Amsterdam on television. ${ }^{116}$ But when we examine the contents of this first collection, we find, just like with the two-volume Piekeransvan een straatslijper, no stories dealing with the period from 1942 to 1949 appear. In other words, "Op zoek naar eten" had not been reprinted, and would not appear in book format until long after his death. The case of "Sonja" is even more pertinent. Mahieu never sent it to be published. So, by the mid-1950s Robinson/Mahieu had, for whatever reason, decided to unremember his memoirs of the Japanese occupation, and to leave the period of decolonization, with the exception of some brief references, unexplored.

Yet, in the year of his first television appearance, 1960, Mahieu's second collection, Tjoek, appeared. Of the eleven stories, three offer lengthy representations of the violence of decolonization. "De Piroes oerat mas" "The Piroes Oerat Mas") tells the story of a Chinese-Indo, Teck Eng, nicknamed "The Invincible." He owed his name to the fact that he seemed indestructible, having survived the war against the Japanese, the massacres of the Bersiap period, the Indonesian revolution; he had survived hunger, unemployment, street fights, bomb attacks and housing shortages, death and insanity. Like other veterans, he had experienced the type of danger that turns your hair white. But he believed that he owed his survival to a precious piece of gold-flecked turquoise that he wore on a chain around his neck, the piroes oeratmas. ${ }^{117}$ Near the end of the story, an awful truth strikes Teck Eng - the stone offered no protection at all. He had simply been lucky, and some day his luck will run out. "I am lost," he realizes (230-231).

The story "De Muur" ("The wall") begins with a paragraph that sums up something essential about Mahieu's representation of war:

Nothing particular ever happens in a city under siege. People live as normally as possible between the attacks. [...] [W]hoever is dead, or 
abducted (which turns out to be the same), the siege is over. For good. Especially in besieged cities, life is far too urgent to waste time on useless emotions concerning the disappeared. [...] [M] any discover that in fact they have been liberated from another type of siege: that of the endless obligations of an organized, respectable society. Where death also comes at some point, but where life is already dying. Here, everyday is life. (235)

The real enemy is not the barbarity of war, it is everyday life, with its stifling duties. The story is set around the time of the second "police action," "as it's called" (236). The prose evokes the intensity experienced during war. The main character, Paul, is driving though enemy territory:

They're getting the machine gun ready. They're priming the mine. There by this corner. The next corner. The next corner. The next corner. The next corner. Suffocate death. In the city they call you glass-hard. And sometimes courageous. People in the safe city are brainless, bloodless, nothing. They're lousy bastards. When you really think about it, you've just got one hatred. Your hate isn't meant for the enemy. He lives just like you. Not for the clerk from social services who you'll soon shoot dead, that's just settling a score. No, the hate is for weak, pasty-faced, eternally nice talking people from the safe city. With their whining about humanity, love of animals, morality (236).

Paul witnesses civilians "who draw suffering like a vagrant draws lice." He has experienced too much brutality in the war and reflects: "I wish I could forget everything. I wish I wasn't Paul, wasn't a European, wasn't a horror. [...] I'm fed up with the tiredness of centuries of Europeanness. [...] I'm tired of working dreaming working dreaming working dreaming" (241-242). Paul meets a young native woman who, since age thirteen, has lived with men, a Japanese commander, an Indonesian rebel commander, and others (244). He is drawn to her himself, but, as a married man, he doesn't want to give into his feelings and he tells her that we must never compromise our principles of trust and purity, while he thinks to himself that civilization is collapsing and if he was completely honest, he should shoot her dead. He realizes that he is a hunter among men: "[W]e kill the most beautiful thing that we can have. Look out, you. Look out, me" (248).

The house that they are in comes under heavy attack and they seek to comfort each other. Paul seems to give into fear, feeling helpless and sinking into forgetfulness, waking up to find the girl asleep next to him. The next morning, standing outside the house, he looks back at the place where he 
spent the night with her. Suddenly he orders his servant to gather their things and they drive away quickly, along lonely roads with "hopefully - a landmine. The landmine" (251).

In these two stories, Mahieu offers us a representation of war in which conflict is not something alien to humans. Instead, war highlights that which is always present, but which we do not see, burdened by the trivialities of everyday life. Normal life suffocates. War confronts us with ourselves. It forces us to choose, to say yes or no. Teck Eng can recognize and acknowledge his own vulnerability, or take refuge in a fairy tale. Paul can accept his animal nature, or choose self-hatred. War provides the opportunity to test our virtues. To become confronted by the certainty of our own death, and to accept or embrace this fact, is to grow stronger. Teck Eng and Paul fail the test. But in another story, entitled "Madjoe," Mahieu presents us with an unnamed protagonist who passes the test.

The protagonist is a man, travelling in Java with his son and his driver in a military pickup soon after the second Dutch "police action." He is a hardened warrior, not easily given to sentimental emotions. In the desolated landscape, they see a crowd of Indonesians, naked and starving, and when they throw them scraps, the crowd turn into screaming, fighting wolves (254). The protagonist wonders why he is never shocked by the brutal scenes that he encounters, even when he comes across body parts of Dutch soldiers blown up by a mine (255). Suddenly, there is an explosion, their vehicle is blown up and he sees his driver, blood oozing from his nose and ears, dead. He hears his son crying. At first the son is thrilled to see his father: "You're the best Dad." But, the son calls out that he is afraid. The father holds him, tells him not to be afraid: "Dying is just going through a door. [...] [W]ait on the other side of the door. I'll come straight after, [...] hunting in the eternal hunting fields," and he sees the young face grow rigid in death (257). When the father stands up, he is surrounded by the crowd, who are armed with primitive weapons. As they move in for the kill, he thinks of his son's words, and he calls out "Madjoe" and attacks the crowd himself (258). The protagonist in this story has no time to mourn the death of his son; instead, he is motivated to attack the threatening crowd by the pride he feels in remembering his son's last words. He has accepted the inevitability of his own death.

Years after the death of Robinson, his wife, Lilian Ducelle, recollected that all of the stories of Mahieu were written when the couple had been living in Borneo in the early $1950{ }^{118}$ This means that Mahieu penned his 
fictional representations of the decolonization conflict before he went into exile, and before his first collection was to receive so much acclaim. It means that, although they were not published until 1960, he wrote them around the same time that he wrote, under the name Tjalie Robinson, his essays based on his memories of the war. Yet, just like with the essays, this was his first and last effort to articulate these painful memories in writing. In other words, Robinson/Mahieu, before repatriation to the Netherlands, had created a small but powerful oeuvre of essays and stories representing the war of decolonization. Upon arrival on Dutch shores, this ceased. Rather than remember, he choose to unremember.

\section{The Silencing of Vincent Mahieu}

One reason for this unremembering was that, once arrived in the former metropole, he found himself a stranger in his new home - "A Dutchman exiled in Holland," as he expressed it. ${ }^{119}$ He discovered that this sense of deep alienation was one that he shared with tens of thousands of his compatriots, totok and Indos. ${ }^{120}$ He repeatedly described how it felt to be an outsider in Holland. $^{121}$

Anderson described how the creoles of the Americas had developed the "capacity to imagine themselves as communities parallel and comparable to those in Europe." ${ }^{122}$ However, the Indisch community had failed to earn themselves a position parallel to the native Dutch. Upon arrival in Holland in 1954, Robinson encountered his chief enemy, assimilation. ${ }^{123}$ He committed himself to forging a new, expanded version of what it meant to be Dutch. Far from stressing purity or authenticity, this new definition would be open to embracing difference, permitting a space for the Indo. He feared that the attempt to assimilate, promoted by Dutch authorities and many Indo leaders, would mean that Indisch culture would disappear totally. He argued that although you could find many Indonesian faces on the streets of Holland, "the face is the only thing that is Indonesian." ${ }^{124}$ Robinson now found himself in the role of what Beekman calls "spokesman for and guru of the exiled Indo society." 25 With the preservation of Indo culture at stake,

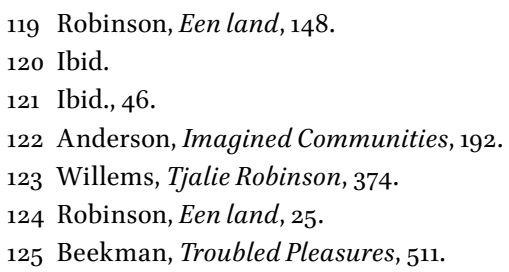


creating literary representations of the war and decolonization must have seemed a form of narcissism.

Robinson, with characteristic energy, threw himself into the battle to save Indisch culture among the diaspora. He took over the editorship of a small Indisch magazine, Onze Brug (Our bridge), which he commandeered as a vehicle for creating an archive of collective memory for the Indisch community. He saw the magazine as a way of waging war against the loss of Indisch memory and identity. By 1958 , he had reinvented the magazine in a new format with a new name - Tong-Tong. ${ }^{126}$ The following year, Robinson founded the Indische Kunstkring Tong-Tong (Indisch art circle Tong-Tong), later renamed the Indische Kuturele Kring (Indisch cultural circle), in order to stimulate Indisch literature and arts. He became one of the initiators of an annual festival of musical performances, dances, readings and interviews, the Pasar Malam Tong-Tong, that grew to become the largest Eurasian festival in the world. ${ }^{127}$

In other words, by the time Mahieu was honoured on television in 1960, Robinson's energy and focus had turned away from writing fiction based on decolonization. His mission had become the shaping of Indisch identity, through the means of the three institutions that he had founded. Nothing more would be heard of the literary writer of fictionalized war memories, Vincent Mahieu. Mahieu had to die in order for Robinson to live and to carry out his task of salvaging Indisch culture. Ducelle maintained that Indische people devoured Robinson's essays, but they had little time for the sort of literature that Mahieu had written. Consequently, he killed Mahieu, "the greatest tragedy of his life." ${ }^{\prime 28}$ Representations of the period from 1942 to 1949 were pushed to the periphery of collective memory. Thus, Robinson became an agent of remembering the colonial world of the Indo and, simultaneously, an agent of unremembering decolonization.

\section{Rob Nieuwenhuys}

Few will dispute Rob Nieuwenhuys' influence upon postcolonial literature in Dutch. Pattynama refers to Nieuwenhuys as the patriarch of Indisch literature while Beekman calls him "the single most influential force for the dissemination of Dutch colonial literature in the Netherlands. ${ }^{129}$ His

126 Willems, Tjalie Robinson, 373-379.

127 Ibid., 397-407.

128 Quoted in Abrahams, "Leven met Tjalie," NRC Handelsblad, 28 March 1992.

129 Pattynama, Bitterzoet, 539. 
book Oost Indisch Spiegel (Mirror of the East Indies) was a milestone in the academic study of Indisch literature. Nieuwenhuys played a key role in the progressive literary journal Orientatie, where he worked with Tjalie Robinson and Beb Vuyk. However, in $195^{2}$ he found himself exiled from the place of his birth. As with Robinson, his tweeslachtig (dual) cultural position would come to colour his vision and work. ${ }^{130}$

\section{Faded Portraits}

Nieuwenhuys began writing his only novel, Faded Portraits, in a Japanese prison camp. He finished it ten years later in Holland. Faded Portraits appeared in 1954 under the pseudonym E. Breton de Nijs. The title suggests we are dealing with a memory work, an attempt to view portraits before they fade away completely. This is enhanced when reading the epigram that precedes the novel, written in English:

"Two sisters keep this little shop;

Jane Memory and Ann Reminder;

When Jane's asleep or not yet up,

Or out or absent, Ann must find her."

In other words, we distinguish between memory as a reservoir of past experiences and memory as the act of recollection. When the reservoir of memories begins to fade, than a conscious act of recollection must be undertaken to salvage what can be retained. Faded Portraits is such an act of recollection, an effort to salvage the world lost through decolonization.

The opening sentence signals the death of the main character: "Aunt Sophie Hortense Cecile Doblijn, née De Pauly, passed away in 1940 in Batavia." We are told that nothing indicated the approaching end. ${ }^{131}$ Inevitably, we think of the sudden death of the colony in 1940, cut-off from the metropole. In retrospect, this marked the end. Breton de Nijs evokes the last days of imperialism seen through the eyes of a narrator who bears the characteristics of Rob Nieuwenhuys.

We are repeatedly reminded that this is a memory work therefore, an inexact reconstruction: we are told that the oldest memories are inexact, memories are unsatisfactory, memory involves forgetting, memories are hazy, foggy or have been wiped away (38-59). When memories resurface involuntarily, they are usually provoked by place or by people. Echoing the 
ideas of Halbwachs and Connerton, the narrator tells us, "I cannot separate Aunt Sophie from her house or her garden, and certainly not from her family" (42). In a passage reminiscent of Dermoût, we get a description of a house and a typical colonial garden. House and garden form a memory palace populated by the novel's characters (26-27).

The narrator's recollections are helped by photographs. He remembers one of a girl who had died aged sixteen. We learn that the album and photograph were lost during the Japanese occupation, so it is the memory of the photograph that remains. The memory seems too authentic, because memory can falsify photographs. The opportunity to check memories with other witnesses has elapsed because they are deceased, or unreachable. The memorialist admits that even the chronology of the narrative is an illusion, determined by act of writing which is shaped by the imagination (54-6o). What Nieuwenhuys is describing is an account of how recollecting works, stimulated by objects and other people, layered and (re)constructed though the imagination, structured by language. Similar to Halbwachs' argument that our memories are not entirely of our own making, the narrator admits: "[M]y impressions are mixed with Aunt Sophie's stories" (74).

The account of the colonial world is that of the upper echelon of Indisch society, the Indo ruling class, "accustomed to giving orders" (48). Nieuwenhuys' novel represents this insular society as one obsessed with social status, European education, the impertinence of the natives, and shades of skin colour (100-134). The colonial elite now find themselves on the cold streets of The Hague, "betrayed and abandoned." The old house is still standing, but decayed and has "lost its purpose" (151-152).

The old empty house is the colony itself. Its current, decayed state symbolizing the loss that the Indisch community endures. What can be salvaged is memories, and this is the task that Nieuwenhuys has set himself - to paint a vivid picture of the world that has been lost. The cause of the loss, the Indonesian revolution, is referred to only once in passing. For Nieuwenhuys, the task has not been to explain decolonization. Like Robinson, his task is to memorialize the world of the Indisch elite in its heyday, before the ugliness of the Japanese occupation and the trauma of the Bersiap. Faded Portraits used photography as an extended metaphor. The title in Dutch, Vergeelde portretten uit een Indisch familiealbum (Faded portraits from an Indisch family album), makes the symbolic reference to photography even clearer.

\section{Tempo Doeloe and the Power of the Photograph}

In 1961, Nieuwenhuys went beyond metaphor, and used the medium of photography directly. Tempo Doeloe: Fotografische documenten uit het oude 
Indië 1870-1914 (Olden days: Photographic documents from the old Indies, 1870-1914) was the first of what became a series of collections of photographs from the old colony, drawn from public and private collections. Out of the thousands perused, Nieuwenhuys, again using the pseudonym Breton de Nijs, selected just over 200 photographs, based on his own subjective choice. ${ }^{132}$

Marianne Hirsch argues that for people in exile, photographs provide an "illusion of continuity." ${ }^{133}$ Images of people lay a direct connection between the exiled and the person photographed. ${ }^{134}$ Robinson and Nieuwenhuys came up with this project in the late 1950s when, in Robinson's magazine Onze Brug, they called for readers to send in all sorts of personal documents that might be used for recording the Indisch past. ${ }^{135}$ They wanted to collect the immaterial legacy of the Indies, in the form of memories (the task of Robinson), as well as material documents, including photographs (the task of Nieuwenhuys). This would provide the basis for the future historiography of their hybrid people. ${ }^{136}$ In 1960 , Nieuwenhuys made another public plea, this time in Robinson's magazine Tong-Tong. He begged readers to search for old photos, the sort of photos one would find in an Indisch family photo album, and to send them to him. He wished to produce a book that "will amaze and astonish Dutch people and that will allow you and me to again relive that land where we spent 'the best years of lives."'137 Pattynama argues that the Dutch public formed his primary intended audience. ${ }^{138}$ His collection of photographs would insert itself into the national collective memory.

Geoffrey Batchen argues that photographic albums are not simply objects with sequenced images but are "prompts for speech, an excuse for friends and families to gather, for stories to be exchanged, incidents to be recalled, biographies to be invented."139 People sit around an album, page through photographs and exchange anecdotes, provoking conversation in a relaxed way that leads to social bonding. The photo album returns us to an oral tradition, shaping the way we speak and remember. No doubt, Nieuwenhuys knew this and hoped that it would lead to renewed conversations among repatriates and the Dutch nation at large. Indeed, the interest that his

132 Breton de Nijs, Tempo Doeloe, 8.

133 Hirsch, Family Frames, xi.

134 Ibid., 19.

135 Tjalie Robinson, "Heeft ook Indisch Nederland historie? En hoe kunnen we helpen haar op te tekenen?," Onze Brug (2 August 1957): 2.

136 Seriese, Finding History, 9-10.

137 E. Breton de Nijs, "Oproep," 7.

138 Pattynama, Bitterzoet, 209.

139 Batchen, Forget Me Not, 49. 
pictures provoked among the Indisch community was immediate, affecting widespread enthusiastic responses. ${ }^{140}$

The collection begins with images of steamships arriving at Batavia. ${ }^{141}$ It ends with passengers embarking on the return journey to Holland and a photograph of four Indische planters standing on the beach in Scheveningen (190-191). The purpose is to lure us onto a journey by means of a visual narrative from Holland to the Indies and back again. It is also a return journey from the 1960 s to the period predating World War One. The final page offers us a photograph of the neglected gravestones of dead colonials somewhere in the Indies. Nieuwenhuys writes: "We can no longer read the names, they have been erased; we can only offer the stereotypical formula - 'Rest in Peace'" (192). Thus, Nieuwenhuys brings us on a journey to a chapter in history that is finished. All that remains is memory.

One effect of leafing through Nieuwenhuys' photographs, is that they instil a feeling of melancholy. They honour a lost world. There is no hint of the disasters that will overwhelm colonial society. The viewers of the 1960 s examined these photographs with a knowing eye, unlike the subjects who stare at the viewer innocently. Susan Sontag has reflected on how overwhelming it is to look at photos of life in Jewish ghettos in Poland in 1938 , knowing that these innocents are about to perish. ${ }^{142}$ Something similar occurs in Nieuwenhuys' collection. The subjects are unaware that they are doomed.

Sontag argues, "death haunts all photographs of people" because those whose image is preserved have already moved closer to their death. ${ }^{143}$ The uncanniness brought on by looking at old photographs comes from the contradiction that they offer simultaneously some sort of presence and an irredeemable absence. ${ }^{144}$ Barthes used the phrase "That-has-been" to describe the almost magical presence that a photograph offers, arguing, "the presence of the thing [...] is the living image of a dead thing." ${ }^{\prime 15}$ More than his fictionalized prose memoir, Nieuwenhuys' selection of photographs of people, colonial buildings and tropical landscapes promoted that contradictory bind, of simultaneous presence and absence, "that-has-been" and that which is no more.

140 Pattynama, Bitterzoet, 208.

141 Breton de Nijs, Tempo Doeloe, 11-16.

142 Sontag, On Photography, 70.

143 Ibid.

144 Ibid., 15-18.

145 Barthes, Camera Lucida, 77-79. 
One of the first photographs in the collection was a group portrait of passengers and crew members on board a ship, taken in 1897. Nieuwenhuys informs us that the lady on the far left is "no one less than the dancer Mata Hari." ${ }^{146}$ We look at her eyes, knowing that the famous dancer will be executed as a spy. We see her innocent face through the lens of her future violent death. It is like examining a fingerprint or a death mask. This is not an innocent choice. The tone is set for the rest of the book. The photographs carefully frame a visual narrative of a flawed but beautiful society pushing forward to the inevitable ending that gives to the whole its meaning. That meaning is decolonization, the ruin of this world.

One family portrait shows a mother and father seated on bamboo seats in the tropical garden with their two sons. The caption reads, "the newly appointed director of the Hotel des Indes with his family, in 1912. The older of the two boys is the compiler of this book" (29). We find photographs accompanied by passages taken from the novel Faded Portraits, by E. Breton de Nijs (32). Thus, Nieuwenhuys shows that his earlier, fictional work can be used to provide a meaning for the reality-based images, while conversely, the images can be used to illustrate his fictional text. Twinned, both provide a stabilizer for memory. These photographs enact what Sontag calls "a way of certifying experience."147 They offer what Barthes called "a certificate of presence" in which "the past is as certain as the present." 148 Nieuwenhuys may have been living near the shores of the North Sea in 1961, but his childhood had been lived in a place of tropical splendour. Though this place no longer existed, it remained in memory. Evoked and shared in prose, in these photographs, these stencils of the past, lived-in-time is made present again.

We also find images that reveal a hard underside of the colonial project: deforestation in Java, police officers abusing a young native boy, a mass execution. Six photographs with scenes from the brutal Aceh War are included. ${ }^{149}$ One shows a group of dark-skinned Dutch soldiers with white officers. They stare at the camera with the dead bodies of the foe piled at their feet (76). Nieuwenhuys tells us that one officer, Van Daalen, had a reputation for showing no mercy, sometimes killing everyone in a conquered settlement and then photographing the dead (68). The most disturbing image shows Van Daalen and his men, posing before the camera on the parapets

146 Breton de Nijs, Tempo Doeloe, 13.

147 Sontag, On Photography, 7.

148 Barthes, Camera Lucida, 87-89.

149 Breton de Nijs, Tempo Doeloe, 51-116. 
of a small wooden fortress. Sprawled on the ground below lie the bodies of the dead enemy. Next to one soldier sits a baby, surrounded by corpses (77).

Paul Bijl suggests that Nieuwenhuys' inclusion of these violent photos, alongside those showing the relaxed tropical lifestyle of the upper-class colonials, did not hinder the development of nostalgia. This was due to "the book's compartmentalized structure in which a nostalgic perceptible order and an imperial perceptible order [...] could exist next to each other." ${ }^{\prime 15} \mathrm{He}$ argues that Nieuwenhuys compartmentalized the photographs of violence within the frame of public life, while the world of tempo doeloe, the period of Dutch colonization in Indonesia, was framed within the private sphere. Here, the violent photos "were no longer a threat to his main story on the Indies." ${ }^{15}$

Nieuwenhuys wrote that the greatest possible research topic for the historian, sociologist and literary scholar would be to examine the origins of the hybrid society where, at its root, we find a native woman - the house servant or concubine of the totok male. ${ }^{15^{2}}$ Dozens of photographs show family life among some of these Indisch families (121-171). We see ethnically mixed families at parties and on holidays, enjoying parades, hunts, commemorations and amateur dramatics. Among these is a photograph of the young father and mother of Tjalie Robinson (125). We also find photographs illustrating the lives of totok couples and their children (172-189). From the look of their clothes, they have gone native. We find a half dozen or so scenes of families sitting together in their garden and on their veranda drinking tea.

Susie Protschky has studied hundreds of family albums from the Dutch East Indies, where the colonial gaze has turned consciously upon itself. Photographs of families drinking tea in the garden or on the veranda are especially common. Protschky notes that such self-representations served the function of framing the domestic ideals for which the Indisch families wished to be remembered - "bourgeois respectability, conjugal civility, the romance of familial contentment and unity." 53

Anderson coined the term "tropical Gothic" to describe the colonial lifestyle that mimicked that of old European aristocracy. The images show an enviable lifestyle of playing the aristocrat, "against a backcloth of spacious mansions and gardens filled with mimosa and bougainvillea, and a large supporting cast of houseboys, grooms, gardeners, cooks, amahs,

150 Bijl, Emerging Memory, 137.

151 Ibid., 165 .

152 Breton de Nijs, Tempo Doeloe, 119.

153 Protschky, "Tea Cups," 46-65. 
maids, washerwomen, and, above all, horses." This was made possible by metropolitan capitalist power, "a power so great that it could be kept, so to speak, in the wings." ${ }^{154}$

Whatever Nieuwenhuys' intentions were, his photographs became triggers for nostalgia. Near the end of his life, this came to plague him. Celebrating Nieuwenhuys' $90^{\text {th }}$ birthday in 1998 , Carl Peters wrote that Nieuwenhuys always resisted nostalgia, but that nostalgia was an "unavoidable and greatly unintended" consequence of his photo books. ${ }^{155}$ The following year Nieuwenhuys died and was obituarized in the national press. Pieter van Zonneveld remarked that Nieuwenhuys had resisted nostalgia. ${ }^{156}$ Kester Freriks quoted Nieuwenhuys as declaring: "Nostalgia, homesickness: these are terrible words. [...] I have no homesickness for the old East Indies. That is passed, it is dead, sunk." ${ }^{157}$ Rudy Kousbroek, admitted that nostalgia was a point of disagreement between him and Nieuwenhuys: "it was as if nostalgia for him [Nieuwenhuys] was something undignified, an admittance of weakness." In contrast, Kousbroek concluded that Nieuwenhuys' photo books were among the most nostalgic in all of Dutch literature. ${ }^{15}$

Aleida Assmann argues that constructive forgetting can be "the foundation for a spiritual innovation, change in identity and a new political beginning." 159 Nieuwenhuys' collection forces us to understand that photographs, on their own, do not necessarily tell us anything. The story often depends upon the framing, including the captions. With a couple of hundred old photographs, he had created a work of salvaging, directed towards building a new future. Nieuwenhuys had provided a family album for the Indisch community to help them recollect together, strengthen their social bond and survive loss. His novel and photographic collection were rooted in the world before decolonization. Decolonization is only the ending that gives the memories their poignancy. Nieuwenhuys joined Dermoût and Robinson as an agent of unremembering. All three directed their gaze through decolonization, not at decolonization. Decolonization formed the rupture that for Dermoût invoked sadness and nostalgic remembering of

154 Anderson, Imagined Communities, 150-151.

155 Carl Peters, "Op afstand van de kletstafel: Rob Nieuwenhuys 9o Jaar," Vrij Nederland, 11 July 1998.

156 Peter van Zonneveld, “Godsamme: Afscheid van Rob Nieuwenhuys," Vrij Nederland, 20 November 1999.

157 Kester Freriks, “Bezield door Indië: Rob Nieuwenhuys (1918-1999)," NRC Handelsblad, 12 November 1999.

158 Rudy Kousbroek, "Heimwee is eeuwig," NRC Handelsblad, 19 November 1999.

159 Assmann, Formen des Vergessens, 59. 
what had been lost. For Robinson and Nieuwenhuys, decolonization was an aberration in the historical development of the Indo. Their memory work was a salvaging act, directed through decolonization, into the colonial world in order to build for the future.

\section{Beb Vuyk: The Memory of Cruelty}

Beb Vuyk was born in Rotterdam in 1905 . As a youngster, she strongly identified with her unknown Indonesian grandmother. Dark skinned and feeling like an outsider, the young Vuyk was a victim of racist-tinged verbal abuse, accentuating her sense of loneliness and alienation. ${ }^{160}$ By her mid-20s, she was the author of short stories, but instead of building her career in the Netherlands, she immigrated to the Dutch East Indies. On the voyage to the colony, she met the man who would become her husband, a man born of a Dutch father and an Ambonese mother. By the outbreak of World War Two, she had published two full-length books and was working on a third, partly finished in a Japanese internment camp, which was published in $1947{ }^{161}$

The Yearbook of the Society of Dutch Literature describes her post-war work as deviating from the norm because, in her vision, "cruelty, betrayal and vengeance was practised with equal conviction on both sides of the demarcation line." Furthermore, her work on "this dirty war" contained "no stereotype image of the enemy," but depicted "the war atrocities and race madness [rassenwaan]," in which cruelty is some sort of sickness. ${ }^{162}$ This makes her representations of decolonization unique among Indisch authors of the time.

Vuyk admitted that her experience of the war had brought about a change in her writing. Life in the Japanese internment camp and six weeks as a prisoner of the Japanese Kenpeitai had caused "the fear of human cruelty" to enter her life, while the onset of the Indonesian revolution meant, "atrocities were committed not by strangers and enemies, by Germans and Japanese, but by our own people, Dutch and Indonesians." ${ }^{163}$ The stories that she published during the late 1940 on and 1950 s were concerned directly with the Japanese war or the war of decolonization. These were published in 1947 under the title De wilde groene geur (The wild green scent) and in 1958 with

16o Vuyk, Verzameldwerk, 425-432.

161 Nieuwenhuys, Mirror of the Indies, 273-274.

162 "Beb Vuyk," in Jaarboek van de Maatschappij der Nederlandse Letterkunde te Leiden, 1991-1992

(Leiden: Maatschappij der Nederlandse Letterkunde, 1993), 181.

163 Vuyk, Verzameld werk, 444. 
the title Gerucht en geweld (Rumour and violence). Vuyk admitted that they were all concerned with human cruelty (445).

"Verhaal van een toeschower" ("Story of a spectator") contained events based on her own experience and referenced experiences relayed to her by the Indonesian leaders Hatta and Sjahrir, as well as Tjalie Robinson. ${ }^{164}$ The story demonstrates, firstly, that cruelty flows forth from an abundance, a form of madness that overwhelms individuals under certain circumstances, regardless of nationality. Secondly, one can survive the loss of loved ones by means of cultivating memory, but, when one's place is destroyed, it becomes difficult to retain a purpose.

The narrator tells how he and the protagonist, Hermans, spent years together as prisoners of the Japanese. ${ }^{165}$ Hermans was an uncomplicated Indo, married to a local woman (364). The two men meet again as patients in a hospital in West Java. Next door is the police station, where the Dutch execute suspected Indonesian fighters (365-369). Another patient, whose wife was killed by Indonesian nationalists, calls for the shooting of all natives and shouts: "Have you ever opened a pit where ten women and children were murdered? And before they were killed. Do you know what was done to them before they were killed?" (369)

Hermans had found himself fighting alongside newly recruited Dutch troops against Indonesian nationalists. The young Dutch had volunteered for service, committed to the idea that they would be fighting the Japanese, but found themselves forced to confront local nationalists. Their initial reluctance evaporated, however, when they found the mutilated bodies of some of their comrades. They were suddenly willing to carry out extrajudicial executions (368).

Hermans tells of how his wife was murdered by a band of anti-Dutch pemudas, one of the first victims of the decolonization conflict. Hermans tells:

I knew what had been happening here in Asia over the years. The slow current of the past 40 years was accelerated by the war. Asia is liberating itself. When the first reports came in, I tried to explain it to our people. They shouted me down. The republic was a Japanese puppet, Sukarno and his pemudas Japanese murderers. I argued against this (371). 
He adds that the murder of his wife changed nothing. He doesn't accuse the Indonesian nationalists of being particularly cruel. On the contrary, he has witnessed brutality among the Dutch, as well as among the Indonesians. "Cruelty is a form of possession, a madness," he concludes (374).

At the end of the story, the narrator visits Hermans in West Java. Hermans admits that he longs for his own island, far to the east, but the coconut plantations are destroyed, leaving him nothing to return to: "You can return to a dead one. I have my memories," but "I cannot live in a dead garden. [...] I don't dare to return." He admits he can find no purpose to living (377-379).

Vuyk represented the conflict as one of great violence, but made clear that no state has a monopoly on violence. The Japanese inflicted cruelty on European prisoners, the Dutch shot Japanese prisoners without a thought, Indonesian nationalists murdered colonials and the Dutch effortlessly shot nationalist suspects. Vuyk offered a merciless analysis of the colonial mindset that only recognizes its own suffering. "There are people" she writes, "who are still obsessed with their time in the camps. [...] The white who has been humiliated by the coloured race, that still eats away at many."166 The exclusive focus on their own suffering is the preeminent characteristic of the mind of the colonialist, according to Frantz Fanon. ${ }^{167}$ Vuyk's story revealed the European myopic obsession with their own suffering, rooted in the racist inability to deal with the humiliation of having been the helpless prisoner of non-whites.

Vuyk's representation of decolonization reflects a sensitivity towards Indonesian nationalism, sympathizing with its aspirations, refusing to condemn its violence. Her story "De jager met zijn schietgeweer" ("The hunter with his gun"), also demonstrated sympathy for the Indonesian point of view. It highlighted the predicament of the Indo as the "in-between" victim of colonialism. He identifies with his superior European status, but is rejected by European civilization because of his dark skin colour. In this story, the female narrator meets an acquaintance, the Indo captain of a ferry. With the War of Independence drawing to an end and the handover of sovereignty looming, he will be serving a newly independent Indonesian population. The captain asks if she agrees that the way to deal with Indonesian revolutionaries is to kill them all. She answers that Indonesian nationalists are part of a pan-Asian phenomenon: "If you want to solve it in that manner, you will have to massacre all of Asia" (400). She explains that she plans to take Indonesian nationality. Astonished, he asks, "You and your husband

166 Ibid., 368.

167 Fanon, Wretched of the Earth, 15. 
want to become natives?" She replies, "No, Indonesians" (402). This is the choice that Vuyk and her husband had taken after independence. ${ }^{168}$ The captain argues that white civilization is superior and he has worked hard to become a captain within the colonial system, and did not want to play the role of servant to the "black lads, the lazy, indolent Asians with their stupid black mugs." She replies, "What have you against blacks, Captain? Aren't you black yourself?" He reacts vehemently, pulls at his own skin and screams, "This black skin, my own skin that I want to tear off. It is the Asian in myself that I hate."169

In Fanon's classic study of the delusions inherent in colonialism, he argues that the person of colour internalizes European unconscious racist attitudes in which black symbolizes original sin: "The white man chooses the black man for this function, and the black man who is white also chooses the black man." This creates a neurotic ambiguity. ${ }^{170}$ It is this self-hatred that Vuyk articulates. Political decolonization had taken place, but the captain remains colonized. His self-hatred is not his own doing. Shaped in the colonial environment, it was brought to light by decolonization. Fanon makes a distinction between those who are black and those who are of mixed heritage. Fanon refers to the former's desire to turn white as "lactification," while the latter possesses the added anxiety of "slipping back" into blackness. ${ }^{171}$ As represented by Vuyk, decolonization had aggravated the Indo fear of relapsing into blackness.

In Vuyk's story "Full of sound and fury," (the title is in English) we are confronted with cruel incidents from the decolonization conflict. Dutch soldiers torture prisoners, beating them with splintered bamboo sticks, while Indonesian forces kill an accused informer with a Japanese sword, having forced him to dig his own grave. ${ }^{172}$ The power of this story stems from its harrowing yet dispassionate account of brutality, based on Vuyk's own experience of the Indonesian revolution, as well as her time spent as a prisoner of the Kenpeitai, the Japanese political police. ${ }^{173}$

Four years after the appearance of Gerucht en geweld, Beb Vuyk published another story that dwelled on the cruelty of decolonization. "De laatste waardigheid" ("The last dignity"). A man shows the narrator a photograph of a pile of corpses of women and children. His own wife and daughter had

168 Scova Righini, “Een leven," 193.

169 Vuyk, Verzameld werk, 404-405.

170 Fanon, Black Skin, 147-148.

171 Ibid., 33-38.

172 Vuyk, Verzameld werk, 411-420.

173 Nieuwenhuys, Mirror of the Indies, 270-272. 
been murdered by a radicalized gang of youths. ${ }^{174}$ The irony is that this man's sympathies, like Vuyk's, lay with the Indonesian nationalists. However, the murder of his family had forced him to choose the Dutch. He explains: "It is terrible to be a native, automatically the lesser of any arbitrary Dutchman. The feeling burns under your skin, it eats away at you. Nationalism gave us a new attitude." ${ }^{.75}$

In these stories, Vuyk gives voice to the underdog, whether the "inbetween" Indo, or the Indonesian victim of colonialism. The absence of nostalgia make the representations all the more powerful. In each story, we encounter depravity. The enemy is subsidiary to the atrocity of the war itself. There are no heroes, yet no one is entirely evil, either. Protagonists are intimately entangled within huge historical forces; options are limited and shaped by conditions. Decolonization is a pan-Asian movement towards liberation. The personalities are not the instigators; rather the European imperialist system has produced its dialectical opposite, a movement for liberation. The Dutch refusal to accept this unleashes the madness of violence and the violence of gangs of Indonesian youths begets the systematic violence of the Dutch war machine. At the same time, there is nothing exceptional in Dutch imperialism.

As she said in an interview near the end of her life: "[M]y work is to a great extent autobiographical. ${ }^{176}$ Biographer Scova Righini argues that after the ending of the Japanese occupation and Sukarno's declaration of independence, together with sociologist Wim Wertheim and Jacques De Kadt, Vuyk called for the immediate Dutch recognition of an independent Indonesia. From that point onward, she became subject to surveillance by the colonial intelligence agency as well as the Dutch domestic intelligence service. ${ }^{177}$ Her critical stance led to her patriotism being questioned and the awarding of a minor book prize was temporarily suspended. ${ }^{178}$ In the late 1950s, her return to the Netherlands led to a minor scandal in a section the conservative press. ${ }^{179}$

Vuyk's work, formed a dissonance against the established discourse. Even today, she evokes widely different responses among scholars. Professor Praamstra, for instance, recently accused Vuyk of being yet another colonial,

174 Vuyk, Verzameld werk, 452.

175 Ibid., 457.

176 Interview in NRC Handelsblad, 30 August 1991.

177 Scova Righini, “Een leven," 162-174.

178 "Beb Vuyk kreeg toegekenden v.d. Hoogtprijs niet betaald," Het Parool, 1 March 1947.

179 Scova Righini, “Een leven," 226-227. 
but one who hid behind a "chameleon-like attitude" towards colonial life. ${ }^{180}$ Such a view I think, is erroneous. I side with David van Reybrouck's verdict. He argues that Vuyk was one of the very few Dutch in the colony who looked beyond her own suffering and that of other Europeans, to discover the far greater suffering of the Indonesians themselves. ${ }^{181}$ As I have argued elsewhere, her stories offer us a window, "through which we are forced to glimpse the uncomfortable reality that is the death-throws of a colony and the birth pangs of a new state as experienced by myriad groups of participants." ${ }^{m 82}$

During the 1950s and 1960s Vuyk's work found a mixed reception in the press. Het Vrije Volk judged Gerucht en geweld successful in portraying the confusion and senselessness of violence, but added that the book was chaotic and confusing. ${ }^{183}$ De Tijd judged the work unimpressive. ${ }^{184}$ One critic noted that she lacked the talent for the complexity of a novel. ${ }^{185}$ Another commented that Vuyk was not really a writer, and her stories missed the penetrating insights of Vincent Mahieu. ${ }^{186}$

However, De Groene Amsterdammer named Gerucht en geweld its "Book of the Month" and some reviewers praised her sober prose and suggestive descriptions. ${ }^{187}$ De wilde groene geur received a positive review in De Volkskrant. ${ }^{188}$ Influential critics Hans Warren and Fred Pfeifer praised her work. ${ }^{189}$ In the Friese koerier, a reviewer claimed Gerucht en geweld should increase her readership. ${ }^{190}$ The Algemeen Handelsblad judged it to be of uneven quality, but admitted that the stories set during decolonization raised the quality of the whole. ${ }^{191}$ Influential journalist Kees Fens praised the collection highly, expressing admiration for how Vuyk had converted the stuff of personal experience into literary stories. ${ }^{192}$

180 Praamstra, “'Going Native,"” 45.

181 Van Reybrouck, Revolusi, 245.

182 Doolan, "Reservoirs," 65

183 Victor Varangot, “Geweld bij Beb Vuyk, rust bij Frits Huel," Het Vrije Volk, 21 November $195^{8 .}$

184 K., "Novellen van Bep Vuyk," De Tijd/De Maasbode, 5 February 1960.

185 H.A. Gomperts, "Avonturiers en Slachtoffers," Het Parool, 5 January 1963.

186 Anne Wadman, "Novellen van Beb Vuyk: De Geur van het Avontuur," Leeuwarder Courant, 30 November 1963 .

187 Scova Righini, “Een leven," 224.

188 A. van de Marke, "Avonturen in Indië en op de Prinsengracht," De Volkskrant, ${ }_{5}$ October 1947.

189 Scova Righini, “Een leven,” 241.

190 "Verhalen van Beb Vuyk," Friese Koerier, 29 November 1962.

191 D.M., “Dimensie Meer?," Algemeen Handelsblad, 12 December 1962.

192 Kees Fens, “Boekenweek Nadert: Verhalen van Beb Vuyk," De Tijd/De Maasbode, 16 March 1962. 
How is it that a woman who had been compared to a traitor and whose stories presented reminders of Dutch brutality, could be reviewed in such moderate terms? Firstly, many reviewers did not mention the content of the stories. Fens' review analyses the formal literary merits, ignoring the content. More importantly, the answer can be inferred from the wording of a number of these reviews. Varangot mentioned that the stories themselves focus on the human aspects and not the political or historical. ${ }^{193}$ Another critic wrote that the stories appealed to those looking for human-interest problems associated with Indonesia after the separation from the Netherlands. ${ }^{194} \mathrm{~A}$ reviewer in the Algemeen Handelsblad claimed that the "very impressively written stories" would bring clarification to those interested in how great historical turning points can influence the individual. ${ }^{195}$

Vuyk's work contends that human depravity is always just a whisper away, and therefore the violence of the Dutch was simply an aspect of being human. This is what the reviewers noticed. Some could pass over the content in silence. Others could reference the Dutch cruelty that emanates from her stories, but dismiss the cruel excesses as a universal, not particularly Dutch, phenomenon. Unremembering held sway in Dutch society. Haasse's Oeroeg entered the reading lists of Dutch secondary schools, not Vuyk's Gerucht en geweld. Vuyk provided an addition to the work of remembering decolonization, but few listened.

\section{The Existentialist}

Albert van der Hoogte's novel Het Laatste Uur: een kroniek uit het na-oorlogse Indonesië (The final hour: A chronicle from post-war Indonesia) was published in 1953. A certain Opzomer, who works as a prosecuting attorney in a district court, narrates the story. Having spent World War Two as a Japanese prisoner, he discovers that his two sons died in a Japanese camp. Opzomer finds himself alone, confronting an existential dread amidst a decaying, rotting colonial society. He tells us: "The old East Indies no longer exists; what there now is, is ravaged, a sad skeleton." ${ }^{196}$ Opzomer admits to himself, "Cowardice and lack of personality are my most significant characteristics"

193 Victor Varangot, “Geweld bij Beb Vuyk, rust bij Frits Huel,” Het Vrije Volk, 21 November 1958.

194 K., "Novellen van Bep Vuyk," De Tijd/De Maasbode, 5 February 1960.

195 B.S., "Het boek: Gerucht en Geweld," Algemeen Handelsblad, 28 April 1960.

196 Van der Hoogte, Het Laatste Uur, 25. 
(89). He fulfils his duties, but has lost his belief in the justice of colonial law: "Indonesians are wiser than we are" (92).

The centrepiece of the novel is formed by the so-called Doyle case. A group of Indonesian peasants set upon a Dutch soldier and his Indo girlfriend. The soldier escapes, but his girlfriend is abducted, severely beaten, gang raped, mutilated and killed, then thrown into a hastily dug grave, possibly still alive. Scores of Indonesian villagers, women as well as men, sing and dance with joy and shout support to the rapists and killers as they watch the brutal spectacle. Van der Hoogte supplies us with a detailed account of this harrowing incident (95-108). When Opzomer interrogate the suspects, he realizes that such collective violence goes beyond reason (111). Yet, he is convinced that in a year's time, back in Holland, "I will hardly be able to remember it," like how the Dutch will unremember the details of their war (115). Opzomer goes through the motions and gets the death penalty for the main perpetrators (124-125).

A group of soldiers carry out the executions. Their officer explains that republican guerrilla fighters had captured three of their comrades, mutilated them horribly, then tortured them to death. The execution provides the opportunity for revenge. Yet, Opzomer, when describing the execution by firing squad, gives us an ambiguous picture, as if it was Calvary that he was witnessing (136-150).

Opzomer visits a district that is terrorized by republican guerrillas. Indonesian representatives of Dutch rule live imperilled lives (182-183). He witnesses the solemn burial of three Dutch soldiers, victims of a mine explosion (187-191). Soldiers live in dread of these devices. In the final section of the novel, Opzomer regains consciousness in a hospital. He discovers that he has been the victim of a detonated mine. Gradually it becomes clear, that he is fatally wounded (193-200). The "final hour" in the title turns out to be Opzomer's final hour, as well as that of the colony. Opzomer is dying, but accepts his being-towards-death. The notes that he is writing, that we are reading, become his expression of existentialist authenticity.

Rob Nieuwenhuys referred to Van der Hoogte's writing as being high quality, specifying that the scene describing the execution of the seven murderers could never be forgotten. ${ }^{197}$ Justus van der Kroef, described The Final Hour as "a first-rate novel [...] that captures the swan song of the Dutch colonial community."198 The book received positive reviews in the national 
press and was reprinted five times within four years of publication. ${ }^{199} \mathrm{Ger}-$ man and French translations soon appeared. ${ }^{200}$ Writing in De Telegraaf, the conservative C. Gerretson mourned the fact that Van der Hoogte had ignored the wonderful years of empire, yet, admitted that this was "the work of an artist of quite some talent."201 The Leeuwarder Courant judged the book to be "a serious attempt to offer [...] a representation of the situation." ${ }^{202}$ Nico Verhoeven of De Tijd referred to it as "the most revealing work of the imagination" to be written about the Dutch-Indonesian conflict. ${ }^{203} \mathrm{~A}$ few years later, he described it as a historical document and an unparalleled modern "classical tragedy."204 In the liberal De Gids, Emmy van Lokhorst claimed that the book provided an "unforgettable representation" of the period. ${ }^{205}$ The book won the prestigious Vijverbergprijs book prize for its "outstanding representation of the time." ${ }^{\text {206 }}$ When Van der Hoogte read a passage from the novel at the official prize giving, the audience, including the mayor of The Hague, was moved to silence, forgetting to applaud. ${ }^{207}$ Novelist Pierre Dubois described The Final Hour as "one of the most moving books in our language about the break with our colonial past." ${ }^{208}$

One critic who disagreed was Beb Vuyk. Writing in the Indonesian newspaper De Nieuwsgier, she accused Van der Hoogte of failing to capture the revolutionary energy of the time, pointing out that the Indonesians in the novel were all either "fearful federalists or the accused in murder cases" while the narrator was so involved with himself that he failed to demonstrate the slightest social curiosity. ${ }^{209}$

Van der Hoogte provided a representation of a rotten, colonial society during its dying days, where even civil servants no longer believe in the system. Soldiers fight a sordid war that politicians in The Hague have given up on. Law courts are a sham. The Dutch army consists of lonely and

199 Swart, "De waardigheid," 133.

200 Ibid., 141-142.

201 C. Gerretson, "Het Laatste Uur," De Telegraaf, 8 August 1953.

202 W.E., "Het land dat wij achterlieten: Romantiek en journalistiek over Indonesië," Leeuwarder Courant, 10 October 1953.

203 N.V., "Geest en Leven," De Tijd, 19 November 1953.

204 Nico Verhoeven, “'Huis van de Nacht' nieuwe roman van Albert van der Hoogte," De Tijd, 2 June 1956.

205 E.v.L., "Nieuwe Boeken," De Gids 119 (1956), 393-394.

206 “Literatuurprijzen van Jan Campertstichting," De Telegraaf, 16 November 1956.

207 “Jan Campert Prijzen Uitgedeeld," De Telegraaf, 1 December 1956.

208 Pierre H. Dubois, “Albert v.d. Hoogte zestig jaar," Het Vaderland, 1 December 1969.

209 Beb Vuyk, “Laatste uur van een somber man,” De Nieuwsgier, 22 July 1953. 
homesick men, many infected with syphilis. The book is populated with colonials who have questionable points of view.

The Final Hour is not only an existential novel, but also a posteschatological one. The greatest problem for the colonials is that they once tasted the privilege of what it was like to be a white colonial in a European empire, the good old days of tempo doeloe or what Anderson called "tropical Gothic." ${ }^{210}$ Now the end has come, but they are doomed to continue living. Opzomer articulates this, realizing that those who survive are incurably sick, like "displaced persons." ${ }^{211}$ This is worsened by the fact that it was all brought to an end by a Japanese invasion. Those "small yellow men have not disappeared; they are still standing behind us, with their squinting, slanty eyes under the peak of their stupid caps and with their bamboo sticks in their hands" (126). He adds, "We experienced the end of the world and our fate is that we survived this ending. We carry on as caricatures" (126).

One thing that made it possible for reviewers to give the work a positive reception, is that the brutal violence in the book comes from Indonesians. The rape scene reveals the Indonesian peasants as barbaric sadists. As Maria Dermoût wrote: "[T]he abduction, rape and torturing, before her death, of the very young Indo girl Betty Doyle, is of an inescapable horror."212 Dutch violence, on the other hand, is institutional and legal. The protagonist's sense of duty forces him to implement the law, even when it means applying the death penalty. Dutch soldiers are victims. They never burn kampongs or torture prisoners. Even the loss of belief among colonialists can be blamed on Asians. Thus, even Carel Gerretson could find much to like in the novel, and Beb Vuyk could find much to dislike. Furthermore, The Final Hour provided no historical explanation for the fall of the Dutch empire in Asia. Ultimately, the imperfectability of humans accounts for the extreme violence of the conflict.

Despite the prize winning and the positive reviews, interest in Van der Hoogte's work waned, as did interest in the history of the colony. Reviewers described it as unforgettable. Yet, time proved them wrong. Van der Hoogte published one more novel set during decolonization, but, some decades after publication, they slipped out of public interest and out of print, becoming

210 Anderson, Imagined Communities, 151.

211 Van der Hoogte, Het Laatste Uur, 126.

212 Maria Dermoût, "Twee boeken over Indonesië: de liefde voor een land is niet te peilen," Vrij Nederland, 30 June 1953. 
no more than "a footnote in the history of Dutch literature."213 Yet, The Final Hour did have an afterlife.

In 2002, Stef Scagliola published Last van de oorlog (Burden of the war). In her attempt to understand what drove Dutch soldiers to commit violent excesses, she examined some of the most brutal acts committed by the nationalist Indonesians. Scagliola refers to a terrible incident from 1945 when a Dutch woman is gang raped, mutilated and murdered. Her source was a memoir from Dutch veteran, Joop Hulsbus. Scagliola quoted over 30 lines from the statement of the chief perpetrator of the crime, as related by Hulsbus. ${ }^{214}$ However, in 2004, Esther ten Dolle published a devastating critique, showing that Hulsbus, in a case of near plagiarism, had lifted his description from Van der Hoogte's novel. As Ten Dolle concluded, "without knowing it, [...] the historian here used a fragment from a novel [...] as a historical source."215 Scagliola had concluded that the murderer had been "encouraged by an entire crowd to abuse in the most cruel manner and murder a Dutch woman," then compounded her error by using this incident to argue that "violence from the Indonesian side that went beyond what Dutch soldiers could imagine."216

Furthermore, in a brilliant piece of detective work, Ten Dolle located the original incident, finding it reported in the Indische Courant between May and August 1948. Even the names of some perpetrators are the same as in The Final Hour. Like Van der Hoogte's fictional case, the historical case was heard at the district court of Surabaya, where Van der Hoogte himself was working. Ten Dolle's argues that Van der Hoogte made use of the court documentation to write his fictional account. Significantly, there is no reference to villagers who shouted their support of the rapists. This was an addition of Van der Hoogte's. ${ }^{217}$ Van der Hoogte's fantasy provides an example of Said's "already existing structure of attitude and reference," whereby imaginative writing on the Other is limited to certain imaginaries, assumptions and intentions. ${ }^{218}$ It drew on colonialism's cultural archive of the brutal native, and this resonated among readers who had been inducted into the same family of ideas. Fifty years later, Scagliola transposed the incident to the Bersiap period in 1945, where it became a politically motivated brutal killing of a Dutch woman. Van der Hoogte's work provides an inaccurate,

213 Swart, "De waardigheid," 134.

214 Scagliola, Last van de oorlog, 84-85.

215 Ten Dolle, "Een moord," 5-6.

216 Scagliola, Last van de oorlog, 85 .

217 Ten Dolle, "Een moord," 8-9.

218 Said, Culture, 248; Said, Orientalism, 201-201. 
even racist, representation of Indonesian violence. Van der Hoogte's fictional representations of Indonesian violence may have been forgotten, and his work out of print, but its trace still shaped representations of Indonesian violence in the twenty-first century, providing an explanatory framework for Dutch military brutality.

\section{Victimhood}

Within the Dutch political elite, the transfer of sovereignty to the Indonesian revolutionary government was difficult to accept. In 1950, former wartime Prime Minister Piet Gerbrandy wrote of "a great calamity, [...] the deprivation of my country of [...] a vital part of its being, under pressure exercised by Britain, the United States and U.N.O."219 He blamed the "meddlers" who "stuck their clumsy fingers in the pie" (72). Gerbrandy, leader of the Protestant Anti-Revolutionary Party, had led the Dutch government in exile in London during World War Two. After the liberation of the Netherlands, he had stepped aside. As the grand old man of Dutch politics and the leader of the forces that eventually triumphed over the evil of Nazism, his prestige was vast.

Gerbrandy did not dilute his praise for Dutch colonialism with Calvinist modesty. He judged that the fair-minded Dutch colonial state echoed "the Garden of Eden before the Fall" (40). This was due to the Dutch "genius for colony-building" (20) in combination with their "most admirable and altruistic motives" (34). This "unique excellence in the sphere of colonial relationships" (42) caused men's minds to open wide, leading to "years of rapid but sensible expansion in very field" (23). The colony was a unique community, free of racial prejudice (34).

Gerbrandy denied that the authorities had encroached on personal liberty, arguing that the Dutch permitted absolute freedom of speech, except when seditious, maintaining that the colony was a Free State (41-47). However, the Great Depression was an economic blizzard that caused hardship, creating fertile ground for a totalitarian ideology that took its cue from Russia and Japan (24). This was led by a small group of self-seeking collaborators who "would sell their souls to the devil" (55).

Although the Japanese occupation of the Dutch East Indies was a severe blow, Gerbrandy believed recovery was possible. Alas, a combination of Dutch errors and interference by ignorant outsiders resulted in disaster 
(11). Men of influence proved to be a "thorn in the side" because they had been members of the "avowedly separatist" De Stuw group (90). The main culprits in Gerbrandy's view were Minister for Overseas Territories Logemann, followed by Van Mook (94). He described Van Mook as "utterly misguided" (135). This situation was aggravated by the fact that during the Catholic-Socialist coalitions between 1946 and 1949, the Socialists were the more influential; the willingness of the Catholics to compromise proved to be tragic $(83-89)$.

Most of Gerbrandy's ire was reserved for foreigners. The British could have stabilized the violent situation, but Mountbatten and General Christison made errors, leading to the appeasement of the Indonesian republican leadership. Consequently, the work of generations of Dutch colonials was lost (95-105). He criticized the UN, which "trained its guns on the Netherlands" after the "police action" of 1947. The result of the UN's pressure meant that the Netherlands, "an ancient sovereign State," was forced to "refrain from taking police action against evildoers" (108-110). Finally, he blamed the Americans for their interference, having been confused by public opinion (117-120).

Gerbrandy held international public opinion in low esteem: "It is a fantastic world in which, of all countries, the Netherlands [...] is singled out and driven to part with our overseas territories" (80). Furthermore, the Dutch "who have builded [sic] sensibly, without the aid of megaphone and microphone, braggartry or bluster, have been stripped and robbed of our birthright in broad daylight" (80).

Gerbrandy argued that politicians in The Hague had failed to protect the rights of the peoples who opposed the Indonesian nationalists and had failed to ensure that these peoples could exercise their right of self-determination. He accused parliamentarians of abandoning their colony and reducing the Netherlands to the status of a minor power, predicting that Indonesia will fall prey to Islamic fanaticism and Soviet totalitarianism (175-183).

Despite his sense of victimhood, Gerbrandy finished on a positive note. Not all was lost because the Netherlands retained West New Guinea and he called upon the Dutch nation to convert New Guinea into "a haven for those who wish to live in conditions of safety and tolerance" (185). He recognized that the Dutch can still "render Western Civilization a service by remaining in New Guinea," tasked with keeping "the flame of civilization burning in the Far East" (190-191).

Gerbrandy's sense of betrayal did not appear out of nowhere. His conservative party, along with the Liberals, had vehemently opposed negotiations with Indonesian republicans. When things went wrong, they made the 
Labour Party and Van Mook the scapegoats. ${ }^{220}$ Gerbrandy had been incensed by the Linggadjati Agreement of 1946. This led him to found the right-wing extraparliamentary movement the Nationaal Comité Handhaving Rijkseenheid (National Committee for Maintaining State Unity). In an emotional speech on the radio, Gerbrandy condemned the bandits running amok on Java and the Dutch statesmen who would betray the nation. He appealed to the Dutch people, saying that they were about to lose World War Two. ${ }^{221}$ His movement rapidly collected 300,000 signatures of citizens opposed to their parliamentary representatives. ${ }^{22}$ Historian Joop de Jong argued that the committee's extreme views reflected the opinions of a large number from Gerbrandy's party as well as Liberals. ${ }^{223}$ Van Doorn points out that repatriated colonials could rely on Gerbrandy for support. ${ }^{224}$ Gerbrandy came to champion the rights of minorities in Indonesia, especially the South Moluccans, in his attempt to retain Dutch influence in the archipelago. ${ }^{25}$ In this context, Gerbrandy's Indonesia echoed the views of a substantial minority of Dutch citizens.

However, the reviews were far from positive. Paul van 't Veer of Het Vrije Volk gave the book short shrift, pointing out Gerbrandy's lack of balance and clear reasoning. ${ }^{226}$ The Protestant Heerenveense Koerier found the scapegoating of the members of the De Stuw group hard to accept, wondering why Gerbrandy would cheat the Indonesians of what the Dutch already had - national sovereignty. ${ }^{227}$ One exception was the extended, positive review from Gerretson in De Telegraaf. ${ }^{228}$ He supported the thesis, consistent with his 1946 Indië onder Dictatuur, that the blood of Dutch soldiers had been spilt due to the selfish manipulations of the leftist De Stuw group. But then, Gerretson was one of Gerbrandy's co-founders of the National Committee for Maintaining State Unity. Described by De Jong as “foul” (vileine), Gerretson's views on colonialism were as extreme as Gerbrandy's. ${ }^{229}$

If he had expected his book to have influence, Gerbrandy must have been disappointed. By the 1950s, few were listening except the colonial die-hards.

220 De Jong, Avondschot, 118.

221 Van den Doel, Afscheid, 350.

222 Bosma, Terug, 17-19.

223 Ibid., 118.

224 Van Doorn, De laatse eeuw, 325.

225 Bosma, Terug, 23.

226 P.v.'t V., "Prof. Gerbrandy over Indonesië," Het Vrije Volk, 31 March 1951.

227 F.S., "Gerbrandy over Indonesië," Heerenveense Koerier, 21 March 1951.

228 Prof. Dr. C. Gerretson, “De Ondergang van het Koninkrijk,” De Telegraaf, 10 February 1951. 229 De Jong, Avondschot, 292. 


\section{The Adventurer}

After the Indonesian War of Independence had ended, the man held responsible for the worst mass killings, Captain Raymond Westering, had become the stuff of legend. In national and regional newspapers throughout the country, and in Dutch-language newspapers in Indonesia, it seemed like his every move was reported on during the 1950 s and early $1960 \mathrm{os}$. This included reports of his arrest (and release) after months of a manhunt; ${ }^{230}$ decisions on whether he should be deported to Indonesia; ${ }^{231}$ rumours of his attempt to infiltrate back into Indonesia to start a counter-revolution; ${ }^{232}$ descriptions of his attempts to create a new ultra-conservative movement; ${ }^{233}$ even accounts of his career and failure as an opera singer. ${ }^{234}$ In 1982, journalist Peter Schumacher claimed that Westerling's name had become "synonymous with the cruelties inflicted by the Dutch soldiers during the police actions."235 His life seemed like that of a character in an opera. Indeed, in 1995 the opera Westerling premiered in Amsterdam. ${ }^{236}$

An inquiry and subsequent report in 1948 had justified Westerling's methods as necessitated by the emergency situation in South Celebes. Frans Goedhart had managed to get a parliamentary motion passed in early 1949, calling for an independent commission to investigate Westerling's use of extreme violence. However, by the time the report was delivered in The

230 "Illegaal reisje in Nederland: Westerling gearresterd," Limburgsch Dagblad, 17 April 1952; "Westerling gearresterd en weer in vrijheid gesteld," Leeuwarder Courant, 17 April 1952; "Westerling gearresterd en weer vrijgelaten," Algemeen Handelsblad, 17 April 1952; "Westerling gearresterd en weer vrijgelaten," Gereformeerd Gezinsblad, 19 April 1952.

231 "Geen reden tot Westerlings uitlevering," Nieuwsblad van Sumatra, 10 June 1952; "Geen uitlevering van Westerling," De Java-bode, 11 June $195^{2}$.

232 "Evipan onderweg naar Engelse haven," Het Vrije Volk, 11 June 1955; "Westerling naar Indonesië," Leeuwarder Courant, 21 September 1955; "Vertrek van Westerling," Leeuwarder Courant, 15 November 1955; "Weet U het allemaal nog," Het Vrije Volk, 13 December 1955.

233 "Nieuwe groepering van Westerling," Friese Koerier, 25 May 1953; "Westerling sticht eigen Partij: De Nederlands Conservatieve Partij," Algemeen Handelsblad, 19 September 1955; "Raymond Westerling voelt zich geen avonturier," De Tijd, 22 June 1955; "Rustig parlementair jaar kreeg door kabinetcrisis einige beroering," Leeuwarder Courant, ${ }_{11}$ December 1955.

234 "Westerling wordt operazanger," Nieuwsblad van het Noorden, 24 December 1956; "De Kleine Wereld," Nieuwsblad van Sumatra, 3 January 1957; "Westerling wordt operazanger," Algemeen Indisch Dagblad, 4 January 1957; "Westerling als opera-tenor," Het Vrije Volk, 17 February 1958; "Raymond Westerling maakte zijn opera-debuut als Cavaradossi," Algemeen Handelsblad, 9 June 1958; “Westerling kan niet capituleren: 'ik blijf op zangles," De Telegraaf, 29 September 1962. 235 Peter Schumacher, "Raymond Westerling en de jungle van het verleden: zelf-rehabilitatie van een eenling," NRC Handelsblad, 18 September 1982.

236 Reinjan Mulder, "Het leven van kapitein Westerling in een opera," NRC Handelsblad, 7 June 1995. 
Hague in 1954, the war seemed to belong to the distant past. The cabinet, in a clear example of unremembering, quietly shelved it. ${ }^{237}$

This did not mean that Westerling's use of violence had been hidden by some sort of cover-up. After all, Van Mook freely admitted that he had ordered the pacification of South Celebes and this involved excesses. ${ }^{238}$ More forcefully, Captain Raymond Westering himself had publically shared the details in a colourful, boastful account. Westerling's Mijn Memoires (My memoirs) was published in 1952. From the first page, we know that we are dealing with no ordinary autobiography. Westerling quickly informs the reader that he was a "miracle child." ${ }^{239}$ By the age of five, he could tame wild animals and snakes, by the age of six he could read bloody crime novels, by the age of seven he had become an excellent shot and by the age of eight he regularly disappeared into the mountains on long hikes (9-11). After joining the Dutch army in exile in 1941, he became an instructor "in silent killing" (28). As an instructor for the Dutch resistance, he boasted that he occasionally slipped across the lines to practise on German enemies (37). Eventually he was shipped to the East, where the real adventure began.

Westerling argued that the average Indonesian wanted the Dutch to restore order. Like Van Mook and Gerbrandy, he blamed the Japanese for stirring up hatred of the Europeans, viewed the Indonesian revolution as an example of the USSR's expanding influence and blamed the British for failing to stop the disorder and the Australians for betraying the Dutch (40-75). Parachuted into Sumatra in 1945, he claimed that the Indonesian peasant was pleased to see his uniform, as it meant the end of terrorism. Meanwhile, fanatics terrorized the population (51-54). He gladly fulfilled his task of restoring order. He described how, almost single-handedly, he rescued hundreds of civilians from three internment camps (61-63). He related that, because of a wager for a bottle of whiskey, he snuck into the camp of a nationalist leader, abducted the terrorist, interrogated him, had him decapitated and returned to camp with the terrorist's head in a biscuit tin. He got his bottle of Black \& White whisky. He admitted his astonishment at his reputation for bloodthirstiness, arguing that this escapade saved lives, as it did not necessitate an all-out attack on the terrorist camp (78-89). He claimed that his way of killing earned him a reputation among the natives, and so the Westerling legend began (91-93). 
In July 1946 he was offered a position in the Royal Netherlands East Indies Army, followed by special orders "from my superiors" to pacify South Celebes (119). He set about executing corrupt police officers publically and ostentatiously, and within days peace was restored in the regional capital (130-131). He described how he walked up to one official who was lunching at the crowded European Society, and simply shot him dead (134).

Westerling argued that he always worked with local informants, gathering information, then entering a village, collecting the villagers together, calling for terrorists to be identified, then executing them on the spot. He maintained that these methods brought about the pacification of the island in less than two months, with only 600 terrorists killed. This led the local people to refer to him, as the "East Indies Robin Hood," and earned him thousands of friends (140-155). Westerling claimed that the numbers had been exaggerated, concluding that, in total, 3,000 to 4,00o were killed by both sides during the pacification. Meanwhile, he became a scapegoat for the Dutch, who refused to publish the military, judicial and parliamentary reports about his operation (157-165). He complained that his name was brought up at the UN as if he was "a bloodthirsty monster" (185).

He resigned his commission because the treachery of politicians disgusted him. Attempting to enter civilian life on Java with his Indo wife, natives came seeking his advice, pleading for protection from nationalist violence (188-199). With the support of General Spoor, he decided to create a private army of 22,000 men (201-206). The locals called him Ratu Adil or "Just Ruler" (206-208).

Westerling described his attempted coup d'état of 1950. He justified this, arguing that he was defending the rights of the federation and the welfare of the natives against tyranny (229-238). He described his escape from Indonesia, his incarceration in Singapore and, having given the authorities the slip, his arrival in Brussels (269-289). Asserting that he was now world famous, he decided to use his fame to warn the world of the global danger that a Moscow-inspired Indonesia constituted (291-299).

Westerling's claim of world fame is only slightly exaggerated. In his own country, his adventures were followed in regional and national newspapers. Yet the Dutch press ignored the publication of his memoir. One journalist did report how shocking it was to read of Westerling boasting of his bloody deeds, but then added that the press has properly reacted to the publication with complete silence. ${ }^{240}$ 
Descriptions of summary executions and mass killings were not something that the Dutch public or journalists seemed to have much stomach for. Moreover, historians showed little interest in an area that might provoke controversy. Westerling was correct. He was made a scapegoat. He avoided prosecution for war crimes, but his name became synonymous with brutality. In 1966, Het Vrije Volk reported that his mass killing of 40,000 people was remembered in South Celebes. ${ }^{241}$ Thus, Dutch society perpetrated the myth that Westerling was an individual adventurer whose hard methods were the exception. A placid press, an inert historical profession and a disinterested public, combined to engage in systematic unremembering.

\section{The Soldier}

In 2013, Annegriet Wietsma and Stef Scagliola broke new ground with the publication of a study on Dutch soldiers and sex during the Indonesian War of Liberation. Their purpose was to inscribe what had remained a blank page in the history of decolonization - how, upon returning to the Netherlands after the cessation of hostilities, the Dutch military left in its wake thousands of abandoned children, as well as the children's mothers, most of whom had traded sex for money. The courageous historians hoped to expose a "well-kept secret" that had been preserved for over 6o years. ${ }^{242}$

The issue of European soldiers having sex with local women had long been problematized by Dutch public opinion. In his study of concubinage in Dutch East Indies, Reggie Bray notes that the colonial army was unique in permitting soldiers and women to live together in an unmarried state within the barracks. Nevertheless, by the late nineteenth century, protests were being voiced and Dutch parliamentarians were concerned that concubinage contributed to the spread of venereal diseases among the soldiers. Furthermore, a serious social concern was the children born from mixed relationships. The presence of such children was widely held to be an indication of the moral collapse of European society. Consequently, by the late 1920s, official toleration for concubinage within the military hand ended. ${ }^{243}$ Ann Laura Stoler agrees that the view that the European colonial 
population was in danger of racial degeneracy was widespread and the abandonment of métis children invoked a "social death."244

Wietsma and Scagliola's book, unlike that of Baay, focused on the war of decolonization. However, it was not the first to deal with this topic. In 1957, Job Sytzen's fictional trilogy of novels, Niet Iedere Soldaat Sneuvelt (Not every soldier dies), Gods Ravijn (God's ravine) and Landgenoten (Compatriots), was published in a single volume. The first two books were set squarely against the background of decolonization. Yet, this work has long lain unremembered. Furthermore, until very recently there was limited information regarding the author. Gert Oostindie has marshalled the basic facts for the authors of nearly 700 egodocuments published by veterans of the conflict, but for Sytzen there are a number of blanks. ${ }^{245}$ Some of these blanks have been filled in, in a short work by Harry Poeze. ${ }^{246}$

At first sight, Niet Iedere Soldaat Sneuvelt is a superficial story of a love affair between newly married Captain Willy Besoyen and a young Dutch widow in Java, Laura Dusart, mother of two young children and a survivor of a Japanese camp. Likewise, the second story, Gods Ravijn, is a doomed love story between a Dutch volunteer soldier and a Dutch nurse, but also a story of spiritual redemption. All the main characters in the trilogy are Dutch. Indonesians are invisible and silent. The Japanese are cruel, Indonesian nationalists are bloodthirsty fanatics. Besoyen and Dusart are near perfect specimens of humanity. Java forms the tropical, languid backdrop to love affairs, an Orientalist fantasy.

A closer reading reveals that the first two stories represent the final years of the Dutch East Indies with some frankness. We learn of soldiers who banish women from the camps, especially "the whores." Entertainment consists of visiting friendly families, cinemas and restaurants, which is "cheaper than whores." Venereal diseases is one of the greatest problems for the Dutch military. Condoms are unavailable and the only way to stay healthy is to stay away from local women. ${ }^{247}$ Dutch authorities carry out raids against infected prostitutes and force them into hospitalization (57). Beyozen offers a beautiful girl a ride in his jeep but is upset when she then offers him sex (88-89). During a night out, he witnesses a slim Chinese girl dancing naked for his drunken comrades (104-107). He admits that if he did not have Laura, he too would pay for sex and probably contract syphilis. He 
compares the sexual behaviour of Dutch soldiers with that of the Germans as well as the Canadians in the Netherlands (171-172), a comparison repeated in Gods Ravijn (295). With soldiers lying in hospital beds with sexually transmitted diseases, he seizes one girl who has been a source of infection and forces her at gunpoint to flee naked from her home (266-270). In Gods Ravijn, the main character causes a scandal when he has a relationship with a Dutch nurse, the scandal being that he infected her with venereal disease (295). We are told that if a soldier has a girlfriend and she becomes pregnant, he is immediately transferred (240). Laura and Willy break up, but Willy discovers that she had been pregnant and, back in Holland, had given birth to their baby girl (278). In Gods Ravijn, we find a reference to Dutch soldiers having sexual relations with their maids, and a number of these relationships result in babies being born in the kampongs (376). The fact that the Dutch army left the by-products of their war making and lovemaking in their wake was not such a "well-kept secret" after all.

The book offers examples of the brutality of life for the Dutch soldier. Having killed Indonesian nationalists, it is considered advisable to not fill in a report, in case it falls into the wrong hands (245). Soldiers sell anti-malaria pills on the black market (24-25). Soldiers are guilty of plundering and confiscating goods (237). One soldier explains the relationship between fighting and sex: "Once you've [...] killed someone with your submachine gun, $[\ldots]$ a woman is no longer something you avoid hurting, [...] but something that you'll take if you feel like it." ${ }^{248}$

Oostindie writes that little immoral behaviour can be found in the nearly 700 soldier's egodocuments that he has studied. Open references to sex hardly occur. He quotes from a number of egodocuments that give the impression that Dutch soldiers withstood the temptations of prostitutes. He then quotes from a select number that give details of soldiers paying for sex. ${ }^{249}$ Although he references Sytzen's trilogy three times, ${ }^{250}$ he fails to reference him in this passage. Instead, he quotes from seven documents published in the twenty-first century, five from the 1990 s and three from the $1980{ }^{.251}$ This gives the inaccurate impression that veterans only wrote about this topic decades after decolonization. But Sytzen's work demonstrates that secrets were never hidden. In the 1950s, a book was available that represented an army with widespread problems. In later decades, we come across frequent

248 Ibid., 58.

249 Oostindie, Soldaat, 246-26o.

250 Ibid., 91, 133, 299.

251 Ibid., 261-264. 
references to a cover-up, but early in the process of (un)remembering, we have a document that attempts to activate remembering, but eventually becomes unremembered itself, even by historians of the twenty-first century.

In June 196o, Sytzen's volume was the second biggest selling book of the month. ${ }^{252}$ Sytzen's publisher claimed that the trilogy "appeals to a large public." ${ }^{253}$ However, the popularity did not last. In 1961, an advertisement for the trilogy claimed that the book provided the reader the opportunity to acquire "understanding for the extreme difficult problems of the lads during the police actions." ${ }^{254}$ Sytzen writes that his story tells of the men who volunteered to fight "the Jap" in order to liberate the Indies but that this became a struggle against misunderstanding back home. ${ }^{255}$ In the third work of the trilogy, Sytzen links the narrative of resistance against the German occupier with the narrative of volunteering to fight for the liberation of the Dutch East Indies. ${ }^{25}$ In other words, the audience for the book is the home front and the purpose, to set the record straight.

Jennifer Foray argues that the immediate post-World War Two period saw various political actors in the Netherlands producing an effective rhetoric, centred around simple binaries of "correct" (Dutch patriots) versus "wrong" (German occupiers and their Dutch collaborators), and "the German occupation of the metropolitan Netherlands and the Japanese occupation of the East Indies were cloaked in the same rhetorical mantle." ${ }^{257}$ Scagliola writes that World War Two was the "exemplary war" and its "good' and 'evil' would provide the main referential framework for post-war Holland." ${ }^{25} 8$ Foray agrees that "memories of World War II overlapped and informed understandings of the decolonization process" and very quickly both sets of events "morphed into one cultural trauma." 259 Within this framework "Sukarno was a traitor, a Japanese puppet, comparable to the Dutch Nazi leader Anton Mussert."26o

Foray argues that by September 1945 division between the Dutch began to complicate this simple vision. By late September, the Dutch Communist

252 "Pearl Buck, Hella Haasse en Hans Martin thans op de lijst-van-vijf," Het Parool, 15 July 1960. 253 "Uitgevers over eigen en andermans boeken - De best verkochte titels," Friese Koerier, 5 January 1963 .

254 De Kampion: Officieel orgaan van de Koninklijke Nederlandsche Touristenbond (January 1961): 39 .

255 Sytzen, Soldaat, 8 .

256 Ibid., 445 .

257 Foray, "The Trauma," 82.

258 Scagliola, "De lange schaduw," 36 .

259 Foray, "The Trauma," 85-86.

260 Ibid., 87 . 
Party demonstrated solidarity with the Republic of Indonesia, leading to the predominantly royalist and Protestant Community of Former Resistance Workers expelling communist resistance veterans from its ranks. ${ }^{261}$ Similarly, the group around Vrij Nederland, under the leadership of Henk van Randwijk, began to take a critical approach and fostered cooperative ties between Dutch progressives and Indonesian nationalists. Therefore, a majority of Dutch felt that a firm line against Sukarno could prevent a catastrophic event, similar to the German occupation, while a smaller group on the left took a more critical approach to Dutch colonialism and its attempts at reconquest. ${ }^{262}$

Sytzen's narrative is consistent with that of the royalist, Protestant members of the resistance who volunteered to liberate the Dutch East Indies after the Allies had liberated the Netherlands. Thanks to Harry Poeze, we now know that Sytzen was in fact the pseudonym of Jacob Jonker, a pastor in the strict Dutch Reformed Church who served as an army chaplain in the Dutch East Indies from 1946 until $1948 .{ }^{263} \mathrm{He}$ was also a member of Gerbrandy's conservative Anti-Revolutionary Party. ${ }^{264}$ Lieutenant Besoyen is a practising member of the Dutch Reformed Church. ${ }^{265}$ Gijs Kotting is the son of a Protestant reverend and the work in which he is the protagonist, Gods Ravijn, is a work of spiritual redemption. Many of the male characters in the trilogy have been involved in the resistance during the German occupation, like Kotting, who had risked his life against the Germans and had been hunted by the Gestapo (306). In the third story, we learn that a student at the Protestant university led a resistance group that forms the background of many of the characters in the previous two novels (454).

One soldier explains that they "volunteered to fight against the Japanese to liberate the Indies" (160-161). Another explains that young men in the former resistance felt obliged to volunteer to liberate Indonesia (316). However, they became disillusioned quickly. Kotting writes to his English girlfriend, "I've wanted all the time to go to the Indies and to fight the Japs. But [...] now I'm here it's just a rotten business" (319). Later he adds that by helping to ensure that Queen Wilhelmina's lands will be liberated by the Dutch, he would be liberated "from the Jerrys, from the wretches and murderers, who hunted us like vermin" (360). A character who appears in all three novels,

261 Ibid.

262 Ibid., 87-89.

263 Poeze, Dominee, 7-9.

264 Ibid., 45 .

265 Sytzen, Soldaat, $136-137$. 
Piet Verkerk, admits he has to volunteer because, "I'll die of shame if I stay here" (532). Most soldiers see Indonesian nationalists as being "poisoned by fanaticism," something learned from the Japanese (42). In other words, they see the conflict as one of those who are "right" against those who are "wrong."

However, Sytzen's work also articulates how the soldiers became disillusioned when they discover that they were defending the rights of bigoted colonialists. Besoyen argues against one colonialist: "If you had thought about the people rather than the billions earned by your companies, we wouldn't have the mess that we now have" (144). Similarly, like Gerbrandy, his books criticize a Dutch government that gives in to American pressure and agrees to a ceasefire, betraying the soldiers (234). Kotting reflects that having been hunted by the Gestapo, and having been moved by patriotism to liberate Indonesia, he is betrayed by his government to the Americans and British (371). He has "no thrust in The Hague anymore" (420). Indeed, even within the former resistance group in Amsterdam, there are critical voices who claim that the Dutch will be playing the role of the SS among the Indonesians (536). The same character, a communist, warns the volunteers that they are servants of world capital (554). Furthermore, the Dutch government avoids fulfilling its responsibility of paying to widows the salaries of husbands who had been killed by the Japanese, and by 1947, the Tour de France received more attention than the war in Indonesia (6o8).

Sytzen's works received some positive reviews. ${ }^{266}$ However, most were not generous. The Algemeen Handelsblad accused Sytzen of writing a superficial love story. ${ }^{267}$ Het Vrije Volk wrote that the second volume was only marginally better than the first. ${ }^{268}$ Another reviewer stated that the first volume was too confrontational and reckoned that Sytzen was trying to sweeten his bad conscience by blaming others. ${ }^{269}$

We have seen that by the late 1940 s leading publications on the left had become critical of the prosecution of the war. By 1949, the futility of the war had become evident. The largest army ever mobilized in Dutch history now had to return, in defeat. Meanwhile, authorities in the Netherlands were intent on rebuilding the country. The framework of "right versus wrong" provided the rhetoric from which the trauma could be (mis)understood.

266 “Notities over boeken," Nieuwsblad van het Noorden, 3 o November 1955; “'Landgenoten' van Job Sytzen," De Tijd, 24 December 1955.

267 "Het boek 'Niet Iedere Soldaat Sneuvelt," Algemeen Dagblad, 1 December 1954.

268 "Ordonnans Gijs Kotting duikt in Gods Ravijn," Het Vrije Volk, 27 December 1954.

269 "Soldaatenleven met 'n korreltje zout," Het Vrije Volk, 15 August 1954. 
Returning soldiers were met by an indifferent public. The veterans believed their exertions and sufferings had served an acceptable goal. However, the society that they returned to did not share this view. ${ }^{270}$ The Dutch public had suffered under the Germans, but had little time for the suffering of Jews and next to no interest in the lot of repatriated Indische people. They had even less sympathy for soldiers who had lost a war. Oostindie tells us that the returning soldiers feared being misunderstood. A number remember the public calling them murderers. More frequently, the response was indifference, leading some to refer to themselves as "the forgotten army."271

Sytzen's early popularity did not reach those of the left of the political spectrum. For them, the adventure in Indonesia had already become an embarrassing aberration, best ignored. By the mid-196os, this disinterest became widespread. Thus, the experience of the Dutch soldier during the war of decolonization in general, and Sytzen's trilogy in particular, was unremembered. Jonker/Sytzen immigrated to Australia, where he continued to work in the Calvinist church. ${ }^{272}$

Tens of thousands of Dutch men and a smaller number of women, military veterans, lived with their memories in their minds, sometimes written on their bodies, in a society that was not interested. Their representations did not fit into the neat binary "right versus wrong" schema. When society eventually did express an interest in the late 196os, it focused exclusively on the issue of their war crimes.

\section{The Historian}

Dutch colonial historiography had been the handmaiden of imperial power, with colonial ideology spoon-fed to future practitioners. ${ }^{273}$ Into the late 196os, Dutch historians denied that the Dutch had ever been involved in "anything that could be called 'imperialism."' ${ }^{274}$ Hugenholtz argues that colonial history had failed to develop into a separate discipline, so close did its ideology resemble that of government power. ${ }^{275}$ Yet there were exceptions.

In the 1920 and 1930s, B.J.O. Schrieke made strides in developing an Indocentric historiography, but this placed him "outside the traditional

\footnotetext{
270 Scagliola, “De lange schaduw," 36.

271 Oostindie, Soldaat, 280-301.

272 Poeze, Dominee, $73-81$.

273 Vogel, De Opkomst, 182.

274 Bloembergen, Colonial Spectacles, 19.

275 Hugenholtz, "Nederlands-Indië," 20.
} 
framework of colonial historiography. ${ }^{276}$ In the 1930s, J.C. van Leur made substantial contributions to a postcolonial approach to Indonesian history, rejecting Eurocentric periodization. ${ }^{277}$ Blaut ranks Van Leur alongside the likes of W.E.B. DuBois and Eric Williams as forming the "first serious critique of Eurocentric historiography."278 This postcolonial perspective developed further during the 1950 os in the work of G.J. Resink. ${ }^{279}$ Nevertheless, these academics produced work far from the centre of Dutch academia. Van Leur never held an academic post. Resink, who choose Indonesian nationality after decolonization and lived in Indonesia, wrote from what he described as "the periphery." 280

Within days of the end of the war in Europe, a newly founded organization was tasked with gathering materials about the German occupation. Its director, Loe de Jong, was eventually tasked with writing a complete history of the war in the Netherlands. Yet, during the 1950s, Dutch historians all but ignored the war in Indonesia. In the 20 years between 1949 and 1969, no Dutch historian of repute made a serious attempt to analyse the process of decolonization. The University of Leiden was the self-styled world centre of expertise for all things Indonesian, especially the Koninklijk Instituut voor Taal-, Land- en Volkenkunde (KITLV, now the Royal Netherlands Institute of Southeast Asian and Caribbean Studies), yet its esteemed faculty avoided the topic.

In 1952 C. Smit published a short study of decolonization, De Indonesische Quastie (The Indonesian question), followed in 1962 by De Liquidatie van een imperium (The liquidation of an empire). His death in 1991 earned him a sympathetic obituary in the NRC Handelsblad, written by a professor of diplomatic history at Leiden. The title of Smit's book De Indonesische Quaestie is misspelt in the obituary and earned a single sentence, in which he is complimented for his businesslike description of the conflict. ${ }^{281}$

Yet, this misrepresents the work. Smit's first book offers an analysis of the failures of Dutch policies. It follows a similar line of argument as De Kadt's De Indonesische Tragedie. Indonesian nationalism was not invented by the Japanese but grew out of the Dutch economic exploitation of the

276 Vogel, De Opkomst, 105.

277 Ibid., 231-232; Wertheim, "Early Asian Trade," 168; Van der Kroef, "On the Writing," 355.

278 Blaut, The Colonizer's Model, 55.

279 Vogel, De opkomst, 14-16; Van der Kroef, “On the Writing," 364-371; Mrázek and Resink, "Coughing," 161-162.

280 Mrázek and Resink, "Coughing," 161.

281 A.E. Kersten, "Historicus van buitenlands beleid en de dekolonisatie," NRC Handelsblad, 21 September 1991. 
Indonesians. ${ }^{282}$ During the 1920 s the Dutch missed the chance of integrating Indonesians into the colonial government due to a lack of imagination (8). They reacted to Indonesian aspirations with executions, arrests and banishment to internment camps (12-17). Like De Kadt, Smit argued that the Declaration of Independence was not a Japanese construction, but was shaped by the nationalist youth movements (46). Most damaging was the inaccurate view that Sukarno was simply a former collaborator with the Japanese (64). The actual fighting only takes up a few lines in Smit's work, but, like De Kadt, he does suggest that the so-called "police actions" were an attempt to solve the problem, "in the old-fashioned, colonial way, with weapons" (140). In short, a couple of years after decolonization, a work of history appeared that provided an argument countering the Dutch myth Sukarno was a Japanese puppet and the international community betrayed the Dutch. To refer to such a work as "businesslike" belittles it. Alas, the work inspired few new historians.

We have seen how Bouman studied the development of Indonesian nationalism in West Sumatra. In 1953, J.M. Pluvier's doctoral dissertation on Indonesian nationalism between 1930 and 1942 was published. Leftist sociologist Wim Wertheim of the University of Amsterdam argued that it covered a "forgotten" chapter of the history of the Indonesian revolution. ${ }^{283}$ Wertheim claimed that for most scholars, the period remained a blank page, allowing them to blame everything on the Japanese occupation. ${ }^{284}$

Pluvier argued that "extreme Dutch chauvinism" had been growing in the colony since the mid-1920s, and in the early 1930 s fascist ideas found wide support among Europeans and Indos. ${ }^{285}$ Indonesian nationalist organizations were confronted with a series of repressive measures (41-42). However, peasant and ethnic organizations with a local character became increasingly oriented towards the idea of great Indonesia (79-85). Moderate groups directed their energies towards social and economic works, but the idea of Indonesian independence remained alive (97-107). Repression meant that radical groups made a tactical decision to reorient themselves as cooperative groups (107-130). But by the early 1940s, repression of radical and moderate groups intensified and Indonesians were wondering if their home would remain a colony for centuries (143-146). Although many Indonesian nationalists sympathized with the Dutch after the German invasion of the 
Netherlands in May 1940, the following years saw them confronted with government intransigence; the chasm between the authorities and the nationalist movement widened (167-193). Pluvier concluded that by the time of the Japanese occupation, trust in European promises had diminished, and Dutch authority left the legacy of Indonesian aspirations ignored (204). Pluvier's work offered a representation in which colonial rule, not Japanese propaganda or international conspiracy, was at the root of the Indonesian revolution. The Dutch had sown the seeds of their own downfall.

In 1959, a promising article entitled "The Indonesian Declaration of Independence: $17^{\text {th }}$ of August 1945" was published by Leiden historian H.J. De Graaf, in which he attempted to unravel the events surrounding the days and hours before Sukarno and Hatta's declaration of independence. His undertaking suggested a preliminary effort to initiate an academic discussion of decolonization. ${ }^{286}$ Alas, the attempt to initiate a debate failed.

The loss of Dutch West New Guinea in 1962 and its incorporation into Indonesia led Smit to write De Liquidatie van een Imperium. But as Henk Hofland wrote, this work remained "safely on the surface." ${ }^{287}$ Compared with his earlier volume, it marked a regression towards unremembering. Firstly, it was a purely diplomatic history of the conflict, a history from above, in which events are the result of decisions taken by political leaders. Secondly, it provided a Eurocentric analysis. Indonesians are represented as being reactive. We get to hear a great deal about the uneasy relationship between Dutch coalition partners, while the political machinations between Indonesian nationalist factions are only alluded to. This Eurocentric focus is deepened by the fact that the book begins with the Indonesian Declaration of Independence. ${ }^{288}$ The prelude to decolonization is unremembered. Smit admitted that he cut out any account of Indonesian nationalism and the period of the Japanese occupation. No explanation is given for this unremembering (5).

Thirdly, Smit all but ignored any actual fighting. We learn that during the first "police action," "Dutch losses were very slight" (81) and that during the second "the losses on the Dutch side were minimal" (141). Indonesian losses are never mentioned. Westerling's use of extrajudicial killing on South Celebes receives one sentence (51). On the other hand, Indonesian gangs are blamed for terrorizing the rural population $(75,130)$, Indonesian 
nationalists are accused of "murder, burnings and intimidation" (89), as well as plundering, running amok and sabotage $(92,104)$.

Nevertheless, Smit's work includes criticism of the Dutch. We are told that the politicians in The Hague were narrow-minded and would have done better allowing Van Mook a freer hand in Batavia (10). Van Mook is blamed for the failure of the Hoge-Veluwe Conference in 1946 (35). The Dutch parliament is criticized for not accepting the Linggadjati Agreement in its "naked" form (50). Smit claimed that the obstinacy of the Dutch parliamentarians caused open military conflict in 1947 (79). Despite its shortcomings, the publication of De Liquidatie van een Imperium meant that Smit had published two representations of the decolonization conflict by 1962, while most Dutch Indonesia experts had published none.

In 1964 journalist Paul van 't Veer wrote the first Dutch biography of Sukarno. Van't Veer suggested that the term "collaborator with the enemy" was a misnomer, because the Japanese were not an enemy of the Indonesians. ${ }^{289}$ Furthermore, Sukarno was not a puppet of the Japanese, because Indonesian independence was the "product of autonomous Indonesian thought." ${ }^{290}$ But this biography was a slight work. It had little to say regarding the years from 1945 to 1949 . With just one passing reference to "atrocities" committed under the command of Westerling, no attempt was made to analyse Dutch military actions. ${ }^{291}$

The following year saw the publication of an eye-witness account of the fall of the Dutch empire by someone who had spent most of his working life in Dutch overseas service. Daniel van der Meulen had risen to the position of Minister of Education in the Dutch East Indies after World War Two. The main message of his volume was that the Dutch and colonial authorities failed to see the rise of Indonesian nationalism as an unstoppable force.

His first encounter with Indonesian nationalism occurred when he attended a meeting in Leiden in 1912 of three nationalist exiles - Raden Suwardi Suriadiningrat, Dr. Tjipto Mangunkusumo and Douwes Dekker. He quoted the latter warning the socialist audience: "If all Javanese spit at the same time, the Dutch will drown." ${ }^{292}$ As a young government administrator in Sumatra, he witnessed the arrogance of colonial rulers, and how this blinded them to the fact that resistance to colonial authoritarianism was becoming systemic (48). Furthermore, he recognized that the "fanatical Muslim" of western

289 Van 't Veer, Soekarno, 40.

290 Ibid., 47.

291 Ibid., 61.

292 Van der Meulen, Ik stond erbij, 17. 
Sumatra, while having been bloodily suppressed by the Dutch, remained inwardly a people who had never been conquered (96-97). The virulence of Islamism emanating from Cairo and the rise of Indian nationalism produced twin forces that influenced a growing anti-colonialism in Indonesia, but the response of the Dutch colonial authorities was to turn Indonesia into a police state (99-111). He added that few in the colonial leadership want to remember the enthusiasm with which they greeted Mussert, the Dutch Nazi leader, when he visited the colony before World War Two (112).

The sudden collapse of the colony, soon after the Japanese invasion, was something which "we as Dutch people should be ashamed of," while the military and civilian leadership, "had no leadership qualities" (130-131). He refused to condemn Indonesians who had served under the Japanese, asking, Who dares to use the word "collaborator" when, practically without putting up a fight, Dutch authority turned these people over to the merciless power of the Japanese? He showed understanding for the Indisch and Indonesian civil servants and military personal who, with the outbreak of the Indonesian revolution, found themselves in the dilemma of feeling double loyalty to the colonial authority and to the new Indonesian government (146-150).

The hero in Van der Meulen's book (if we discount the author himself, who we never witness making an error) is Van Mook. He is described as a "strong, courageous, tireless character, who clearly was the leader" (164). Although Van Mook was blinded by optimism in his attempt to forge an Indonesian federation, "he retained until the end [...] my full respect" (26o).

The fundamental errors were those of political leaders in The Hague (240), especially the right-wing leaders (26o). The consequence of these mistakes were the two "police actions," which are described in just two pages (261-262). In other words, like in the works of Smit, Van Meulen gives us an account of a war shorn of any fighting. His rosy-coloured representation of Van Mook reflects his own view that Indonesia could have transitioned into independence under the tutelage of enlightened colonials like himself; a late colonial - but nevertheless a colonial - point of view.

The 196os saw discussions concerning the nature of Dutch imperialism, sparked by the crisis around West New Guinea. Arend Lijphart's The Trauma of Decolonization: The Dutch and West New Guinea (1966) had only a little to say about the period from 1945 to 1949. He argued that in the case of West New Guinea, "subjective and psychological factors can be sufficiently powerful to constitute by themselves the driving force behind colonialism and the obstacle to decolonization." ${ }^{293}$ Lijphart accounted for what made the 
Dutch withdrawal from the Indies traumatic. Firstly, the colony was by far the biggest in the Dutch empire, which made its loss deeply felt. Secondly, Dutch ignorance of developments during the period from 1942 to 1945 and their strong desire to return to the normalcy of the pre-war period led to a deep sense of shock when confronted by Indonesian mass nationalism, compounded by the conviction of the Dutch that "they were one of the most enlightened and progressive colonizing states in the world" (106-107). Thirdly, the metropole felt a sincere attachment to the colony (108). Fourthly, the Dutch had a sense that they had been betrayed by the rest of the world, especially by their allies Britain and the USA (108). Finally, the "proverbial stubbornness" as well as the "intensely legalistic outlook" of the Dutch (109) played a role. These five factors accounted for the intense pain of decolonization, according to Lijphart. In both 1945-1949 and the period around the loss of West New Guinea in 1962, Lijphart concluded that the Dutch "acted with an intense emotional commitment, manifested in pathological feelings of self-righteousness, resentment and pseudo-moral convictions" but this had now transformed into "a compulsive urge to forget" (285-286).

A small number of other influential works did appear in the 1950s and early 196os, but as Henk van den Doel pointed out, they were all written by foreigners. ${ }^{294}$ Jan Bank, recommended that if one wanted to search for historical works that gave a balanced account of the Indonesian revolution, one needed to look to the works of American and Australian historians, adding that Dutch historiography on the subject "has made little progress." 295 Andrew Goss wrote, "During the 1950s, the history of colonialism was not forgotten, but certainly was institutionally ignored. For historians and other scholars, [...] the Netherlands East Indies was an embarrassment and of little relevance to building a new Dutch culture. ${ }^{296}$ Henk Wesseling agreed that the

Dutch war in the Indies [...] received virtually no attention at all: no institute, no television series, no scholarly articles, official or unofficial, [...] only a few unread novels and some forgotten memoirs. [...] In short there existed no historical view of colonization and decolonization. ${ }^{297}$

This situation of historiographical inertia was about to change abruptly, though not thanks to any historian. 


\section{Bibliography}

Anderson, Benedict. Imagined Communities: Reflections on the Origin and Spread of Nationalism. Rev. extended ed. London and New York: Verso, 1991.

Assmann, Aleida. Cultural Memory and Western Civilization: Functions, Media, Archives. New York: Cambridge University Press, 2011.

Assmann, Aleida. Formen des Vergessens. Göttingen: Wallstein Verlag, 2017.

Auge, Marc. Non-Places: An Introduction to Supermodernity. London and New York: Verso, 2008.

Baay, Reggie. De njai: Het concubinaat in Nederlands-Indië. Amsterdam: AthenaeumPolak\&Van Gennep, 2008.

Bank, Jan. Katholieken en de Indonesische Revolutie. Barn: Ambo, 1983.

Barthes, Roland. Camera Lucida: Reflections on Photography. Translated by Richard Howard. London: Vintage Books, 1993 [1980].

Batchen, Geoffrey. Forget Me Not: Photography and Remembrance. New York and Amsterdam: Princeton Architectural Press/Van Gogh Museum, 2004.

Beekman, Eric M. Introduction to Mirror of the Indies: A History of Dutch Colonial Literature by Rob Nieuwenhuys, xii-xxiii. Translated by Frans van Rosevelt. Edited by E.M. Beekman. Amherst: University of Massachusetts Press, 1982 [1972].

Beekman, Eric M. Troubled Pleasures: Dutch Colonial Literature from the East Indies 1600-1950. Oxford: Clarendon Press, 1996.

Bhabha, Homi K. The Location of Culture. London and New York: Routledge, 1994. Bijl, Paul. Emerging Memory: Photographs of Colonial Atrocity in Dutch Colonial Remembrance. Amsterdam: Amsterdam University Press, 2015.

Bissell, William Cunningham. "Engaging Colonial Nostalgia." Cultural Anthropology 20, no. 2 (2005): 215-248.

Blaut, James M. The Colonizer's Model of the World: Geographical Diffusionism and Eurocentric History. New York and London: Guildford Press, 1993.

Bloembergen, Marieke. Colonial Spectacles: The Netherlands and the Dutch East Indies at the World Exhibitions. Translated by Beverley Jackson. Singapore: Singapore University Press, 2006

Bogaerts, Els. “Tussen tekst en herinnering: Maria Dermoûts Java's.” Indische Lettern 15 , no. 2 (2000): 50-67.

Bosma, Ulbe. Terug uit de Koloniën: Zestig jaar postkoloniale migranten en hun organisaties. Amsterdam: Bert Bakker, 2009.

Bosma, Ulba, Remco Raben and Wim Willems. De Geschiedenis van Indische Nederlanders. Amsterdam: Bert Bakker, 2006.

Breton de Njs, E. Faded Portraits. Translated by Donald and Elsje Sturtevant. Amherst: University of Massachusetts Press, 1982 [1954].

Breton de Nijs, E. “Oproep.” Tong Tong 3, no. 23 (1960): 7. 
Breton de Nijs, E. Tempo Doeloe: Fotografische documenten uit het oude Indië 1870-1914. Amsterdam: Querido, 1961.

Brocades Zaalberg, Thijs and Wim Willems. "Onmacht. Ontkenning en Onderschatting: De evacuaties van Nederlanders uit Zuidoost-Azie na de Tweede Wereldoorlog." In Binnenkamers: Terugkeer en opvang na de Tweede Wereldoorlog - Besluitvorming, edited by Conny Kristel, 63-92. Amsterdam: Bert Bakker, 2002.

Connerton, Paul. How Modernity Forgets. Cambridge: Cambridge University Press, 2009.

Cottaar, Annemarie and Wim Willems, Indische Nederlanders: Een onderzoeknaar beeldvorming. The Hague: Moesson, 1984.

Dermoût, Maria. The Ten Thousand Things. Translated by Hans Koning. New York: NYRB Classics, 2002 [1956].

Dermoût, Maria. Verzameld Werk. Amsterdam: Querido, 2000.

Doel, Henk W. van den. Afscheid van Indie: de val van het Nederlandse imperium in Azie. Amsterdam, 2000.

Dolle, Esther ten. "Een moord in Indonesië: feit en fictie achter de geweldexcessen. Hollands Maanblad 45, no. 4 (2004): 3-11.

Dolle, Esther ten. "Morality Is Another Story." Dutch Crossing 27, no. 2 (2003): 169-180.

Doolan, Paul. "Marie Dermoût and 'Unremembering' Lost Time." Canadian Journal of Netherlandic Studies 34, no. 2 (2013): 1-28.

Doolan, Paul. "Reservoirs of Violence: Beb Vuyk's postcolonial stories." Canadian Journal of Netherlandic Studies 40, no. 2 (2020): 39-70.

Doorn, Jacques A.A. van. De laatste eeuwvan Indië: Ontwikkeling en ondergang van een koloniaal project. Zutphen: Walburg Pers, 1994.

Doorn, Jacques A.A. van. Gevangen in de tijd. Over generaties en hun geschiedenis. Amsterdam: Boom, 2002.

Fanon, Frantz. Black Skin, White Masks. Translated by Charles Lam Markmann. London: Pluto Press, 1986 [1952].

Fanon, Frantz. The Wretched of the Earth. Translated by Richard Philcox. New York: Grove Press, 2004 [1961].

Foray, Jennifer L. "The Trauma of Liberation: Dutch Political Culture and the Indonesian Question in 1945." Historical Reflections 41, no. 3 (2015): 79-94.

Freriks, Kester. Geheim Indië: Het Leven van Maria Dermoût 1888-1962. Amsterdam: Querido, 2000.

Gerbrandy, Pieter S. Indonesia. London and New York: Hutchinson, $195^{\circ}$.

Goss, Andrew. "From Tong-Tong to Tempo Doeloe: Eurasian Memory Work and the Bracketing of Dutch Colonial History, 1957-1961." Indonesia 70 (October 200o): 9-36.

Goos, Marije. Een hard en waakzaam hond: Engagement in de literaire tijdschrijften van "de lange jaren vijftig" 1950-1963. Hilversum: Verloren, 2016. 
Graaf, Hermanus J. de. “The Indonesian Declaration of Independence: $17^{\text {th }}$ of August 1945." Bijdragen tot de Taal, Land en Volkenkunde 115, no. 4 (1959): 305-327.

Halbwachs, Maurice. On Collective Memory. Edited and translated by Lewis A. Coser. Chicago and London: University of Chicago Press, 1992 [1950].

Hirsch, Marianne. Family Frames: Photography, Narrative and Postmemory. Cambridge MA and London: Harvard University Press, 1997.

Hofland, Henk J.A. Tegels lichten of Ware verhalen over de autoriteiten in het land van de verdrongen feiten. $5^{\text {th }}$ ed. Amsterdam: Bert Bakker, 1986 [1972].

Hoogte, Albert van der. Het Laatste Uur: een kroniek uit het na-oorlogse Indonesië. Amsterdam/Antwerp: Contact, 1953.

Houtzager, Guus. "Maria Dermoûts De tienduizend dingen: Technisch raffinement, tovenarij en taoïsme." Indische Letteren 1, no. 2 (1986): 67-87.

Hugenholtz, Wouter R. "Nederlands-Indië en het Gouvernmentele Paradigma." Groniek 17 (1982): 20-28.

Huxley, Aldous. The Perennial Philosophy. London: Chatto and Windus, 1946.

Jong, Joop J.P. de. Avondschot: Hoe Nederland zich terugtrok uit zijn aziatisch imperium. Amsterdam: Boom, 2011.

Kristel, Conny. "Inleiding." In Binnenkamers: Terugkeer en opvang na de Tweede Wereldoorlog-Besluitvorming, edited by Conny Kristel, 7-21. Amsterdam: Bert Bakker, 2002.

Kroef, Justus M. van der. "The Colonial Novel in Indonesia." Comparative Literature 10, no. 3 (Summer 1958): 215-231.

Kroef, Justus M. van der. "On the Writing of Indonesian History." Pacific Affairs 31, no. 4. (1958): 352-371.

Leeuwen, Lizzie van. "Het Indisch Huis." In Een Open Zenuw: How wij ons de Tweede Wereldoorlog herinneren, edited by Madelon de Keizer and Marieke Plomp, 275-282. Amsterdam: Bert Bakker, 2010.

Lijphart, Arend. The Trauma of Decolonization: The Dutch and West New Guinea. New Haven and London: Yale University Press, 1966.

Mahieu, Vincent. Verzameld werk. Amsterdam: Querido, 1992.

Meulen, Daniel van der. Ik stond erbij: het einde van ons koloniale rijk. Baarn: Bosch en Keuning, 1965.

Mrázek, Rudolf and Gertrudes Johan Resink. “Coughing Heavily: Two Interviews with Professor Resink in His Home at Gondangdia Lama 48A, Jakarta, on July 17 and July 25, 1997." Indonesia 74 (October 2002): 137-164.

Nas, Peter J. M. and Maaike Boersma. "Feeling at Home, Dealing with the Past: Indonesian and Colonial Architecture in the Netherlands." In The Past in the Present: Architecture in Indonesia, edited by Peter J. M. Nas, 147-162. Rotterdam: NAi Publishers, 2006. 
Nieuwenhuys, Rob. Mirror of the Indies: A History of Dutch Colonial Literature. Translated by Frans van Rosevelt, Edited with an introduction by E.M. Beekman. Amherst: University of Massachusetts Press, 1982 [1972].

Nieuwenhuys, Rob. Oost-Indische spiegel. Wat Nederlandse schrijvers en dichters over Indonesië hebben geschreven vanaf de eerste jaren der Compagnie tot op heden. Amsterdam: Querido, 1972.

Nieuwenhuys, Rob. Tussen Twee Vaderlanden. Amsterdam: G.A. van Oorschot, 1959.

Oostindie, Gert. Post Koloniaal Nederland: Vijfenzestig jaarvergeten, herdenken, verdringen. Amsterdam: Bert Bakker, 2010.

Oostindie, Gert. Soldaat in Indonesië 1945-1950: Getuigenissen van een oorlog aan de verkeerde kant van de geschiedenis. Amsterdam: Prometheus, 2015.

Oostindie, Gert, Henk Schulte Nordholt and Fridus Steijlen. Postkoloniale Monumenten in Nederland/Post-Colonial Monuments in the Netherlands. Leiden: KITLV Press, 2011.

Passman, Bert. "Van Tjalie zijn wij nog niet af." In Tjalie Robinson: de stem van Indisch Nederland, edited by Bart Passman, Wilma Scheffers, Edy Seiese, Peter Zonbeveld and Adrienne Zuiderweg. The Haag: Stichting Tong Tong, 1994.

Pattynama, Pamela. Bitterzoet Indië: Herinnering en nostalgie in literatuur, foto's en films. Amsterdam: Prometheus-Bert Bakker, 2014.

Pattynama, Pamela. "Cultural Memory and Indo-Dutch Identity Formations." In Post-Colonial Immigrants and Identity Formations in the Netherlands, edited by Ulbe Bosma, 175-192. Amsterdam: Amsterdam University Press, 2012.

Pattynama, Pamela. “Herinneringsliteratuur en 'postherinneringen' bij eerste en tweede generatie Indische schrijvers." In Kunsten in Beweging: Cultuur en migratie in Nederland, edited by Rosemarie Buikema and Maaike Meijer, 207-221. The Hague: Sdu, 2003.

Pattynama, Pamela. “'Laat mij voor één keer schaamteloos terug verlangen...’: De herinneringsknoop van Indische nostalgie." Indische Letteren 23, no. 2 (2008): $5^{0-62 .}$

Pattynama, Pamela. "Postkoloniale Erinnerung an (Niederlandisch-) Indien: koloniale Vergangenheit, kulturelle Erinnerung und Literatur." In Kolonialismus und Erinnerungskultuur: Die Kolonialevergangenheit im kollectiven Gedächtnis der deutschen und niederländischen Einwanderungsgesellschaft, edited by Helma Lutz and Kathrin Gawarecki, 111-126. Munster: Waxman Verlag, 2005.

Pattynama, Pamela. "(Un)happy Endings: Nostalgia in Postcolonial and Postmemory Dutch Films." In The Postcolonial Low Countries: Literature, Colonialism, Multiculturalism, edited by Elleke Boehmer and Sarah de Mul, 97-122. Plymouth: Lexington Books, 2012.

Pluvier, Jan M. Overzicht van de ontwikkeling der nationalistische beweging in Indonesië in de jaren 1930-1942. The Hague/Bandung: W. van Hoeve, 1953. 
Poeze, Harry A. Dominee Jac. Jonker, Job Sytzen en de Soldaat in Indië. Hilversum: Verloren, 2019.

Praamstra, Olf. "Afscheid en de grenzen van de tijd: animistische ideeën in $D e$ tienduizend dingen van Maria Dermoût." In Kerven in een rots: Opstellen over nederlandse taalkunde, letterkunde en cultuur, aangeboden aan Jan W. de Vries bij zijn afscheid als hoogleraar Dutch Studies aan de Universiteit Leiden, edited by Berry Dongelmans, Josien Lalleman and Olf Praamstra, 191-201. Leiden: Stichting Neerlandistiek, 2001.

Praamstra, Olf. “'Going Native': Beb Vuyk en het verlangen naar een Indonesische Identiteit." Spiegel der Letteren 58, no. 1 (2016): 43-81.

Praamstra, Olf. "A World of Her Own: The Eurasian Way of Living and the Balance between East and West in Maria Dermoût's The Ten Thousand Things." In Shifting the Compass: Pluricontinental Connections in Dutch Colonial and Postcolonial Literature, edited by Jeroen Dewulf, Olf Praamstra and Michiel van Kempen, 56-68. Newcastle: Cambridge Scholars Publishing, 2013.

Protschky, Susie. “Tea Cups, Cameras and Family Life: Picturing Domesticity in Elite European and Javanese Family Photographs from the Netherlands Indies 1900-1942." History of Photography 36, no. 1 (2012): 44-65.

Raben, Remco. “De dagen van de grote uittocht?" Indische Letteren 32, No. 1 (2017): 20-32.

Reybrouck, David van. Revolusi: Indonesië en het onstaan van de modern wereld. Amsterdam: De Bezige Bij, 2020.

Ricoeur, Paul. Memory, History, Forgetting. Translated by Kathleen Blamey and David Pellaur. Chicago and London: University of Chicago Press, 2004.

Robinson, Tjalie. Een land met gesloten deuren. Haarlem: In de Knipsheer, 2011.

Robinson, Tjalie. "Heeft ook Indisch Nederland historie? En hoe kunnen we helpen haar op te tekenen?" Onze Brug (August 1957): 2.

Robinson, Tjalie. Kind van Batavia. Amsterdam: Prometeus Books, 2011.

Robinson, Tjalie. Piekerans van een straatslijper, 2 vols. Bandung: Masa Baru, 1952-1954.

Robinson, Tjalie. Taaie en Neut. The Haag: Edauw and Johannissen, 1994.

Robinson, Tjalie. “Tienduizend Dingen van Maria Dermoût.” Tong Tong 3 (August 1958): 2-3.

Robinson, Tjalie. Tjalie Robinson to J.W. Meyer Ranneft, 18 July 1955. In Schrijven met je vuisten: Brieven van Tjalie Robinson, edited by Wim Willems, 77-80. Amsterdam: Prometheus, 2009.

Robinson, Tjalie. Tjalie Robinson to J.W. Meyer Ranneft, 21 July 1955. In Schrijven met je vuisten:Brieven van Tjalie Robinson, edited by Wim Willems, 81-84. Amsterdam: Prometheus, 2009. 
Robinson, Tjalie. Tjalie Robisnon to Maria Dermoût, 16 November 1955. In Schrijven met je vuisten: Brieven van Tjalie Robinson, edited by Wim Willems, 108-113. Amsterdam: Prometheus, 2009.

Romein, Jan M. The Asian Century: A History of Modern Nationalism in Asia. Translated by R. T. Clark. London: George Allen and Unwin, 1962.

Romein, Jan M." The Spirit of the Dutch People during the Occupation." Annals of the American Academy of Political and Social Science 245, (May, 1946): 169-180.

Rosaldo, Renato. “Imperial Nostalgia.” Representations 26 (1989): 107-122.

Rosinska, Zofia. "Emigratory Experiences: The Melancholy of No Return." Memory and Migration:Multidisciplinary Approaches to Memory Studies, edited by Julia Creet and Andreas Kitzmann, 29-42. Toronto: University of Toronto, 2011.

Rushdie, Salman. Imaginary Homelands: Essays and Criticism 1981-1991. Harmondsworth: Granta Books, 1991.

Said, Edward W. Culture and Imperialism. London: Vintage, 1994.

Said, Edward W. Orientalism. London: Penguin Books, 2003 [1978].

Said, Edward W. Out of Place: A Memoir. London: Granta Books, 2000.

Salverda, Reinier. 2004. "De dingen en hun verhaal." In Wandelaar onder de palmen. Opstellen over koloniale en postkoloniale literatuur, edited by Michiel van Kempen, Piet Verkruijsseen and Adrienne Zuiderweg, 213- 226. Leiden: KITLV, 2004.

Scagliola, Stef. "De lange schaduw van een verloren oorlog." In Oorlog! Van Indië tot Indonesië 1945-1950, edited by Esther Wils, 36-38. Arnhem: Museum Bronbeek, 2015. Scagliola, Stef. Last van de oorlog: de Nederlands oorlogsmisdaden in Indonesië en hun verwerking. Amsterdam: Balans, 2002.

Scova Righini, A. A. "Een Leven in twee vaderlanden: Een biografie van Beb Vuijk." PhD diss., University of Amsterdam, 2004.

Sedikides, Constantine, Tim Wildschut, Jamie Arndt, and Clay Routledge. "Nostalgia: Past Present and Future." Current Directions in Psychological Science 17, no. 5 (2008): 304-307.

Seriese, Edy. Finding History: The Inheritance of the IWI Collection: Research Report for PhotoCLEC - Photographs, Colonial Legacy and Museums in Contemporary European Culture, IP2 - Indies Images of the Colonial Everyday in a Multi-Ethnic Postcolonial Society. Amsterdam: Indisch Wetenschappelijke Instituut, 2011.

Smit, Cornelis. De Indonesische Quaestie. Leiden: E.J. Brill, $195^{2}$.

Smit, Cornelis. De Liquidatie van een Imperium. Amsterdam: De Arbeiderspers, 1962. Sontag, Susan. On Photography. London. Penguin Books, 2002 [1977].

Stoler, Ann Laura. "Sexual Affronts and Racial Frontiers: European Identities and the Cultural Politics of Exclusion in Colonial Southeast Asia." In Hybridity and its Discontents: Politics, Science, Culture, edited by Avtar Brah and Annie E. Coombes, 19-55. London and New York: Routledge, 2000. 
Swart, Rolf. “De waardigheid van een ernstige schrijver.” In Jaarboek Letterkundig Museum, 133-142. The Hague: Nederlands Letterkundig Museum en Documentatiecentrum, 1995 .

Sytzen, Job. Soldaat/Ravijn/Landgenoten. Leiden: Slijthoff, 1957.

Trouillot, Michel-Rolph. Silencing the Past: Power and the Production of History. Boston: Beacon Press, 1995.

Thiam, Marie-Helene. "Een wereld vol geesten: Het Moluks animistische volksgeloof in De Tienduizend Dingen." Indische Letteren 15, no. 2 (2000): 68-82.

Veer, Paul van 't. Soekarno. The Hague: Kruseman, 1964.

Vogel, Jaap. De opkomst van het Indocentrische geschiedbeeld: Leven en werken van B.J.O. Schrieke en J.C. van Leur. Hilversum: Verloren, 1992.

Vuyk, Beb. Verzameld werk. Amsterdam: Querido, 1981.

Walder, Dennis. Postcolonial Nostalgias: Writing, Representation and Memory. New York and London: Routledge, 2011.

Wertheim, Wim F. "Early Asian Trade: An Appreciation of J.C. van Leur." Far Eastern Quarterly 13, no. 2 (1952): 167-173.

Wertheim, Wim F. Preface to Overzicht van de ontwikkeling der nationalistische beweging in Indonesië in de jaren 1930-1942, by J. M. Pluvier, v-viii. The Hague/ Bandung: W. van Hoeve, 1953.

Wesseling, Henk L. "Post-Imperial Holland." Journal of Contemporary History 15 , no. 1 (1980): 125-142.

Westerling, Raymond Paul Pierre. Mijn Memoires. Antwerp/Amsterdam: P. Vink, $195^{2}$.

Wietsma, Anne and Stef Scagliola. Liefde in tijden van oorlog: Onze jongens en hun verzwegen kinderen in de Oost. Amsterdam: Boom, 2013.

Willems, Wim. Introduction to Kind van Batavia, by Tjalie Robinson, 7-11. Amsterdam: Prometeus Books, 2011.

Willems, Wim. Tjalie Robinson: biografie van een Indo-schrijver. Amsterdam: Bert Bakker, 2009.

Willems, Wim. Van wie is de geschiedenis? Bekentenissen van een biograaf. Amsterdam: Bert Bakker, 2013.

Woude, Johan van der. Maria Dermoût:De Vrouw en de Schrijfster. The Hague and Rotterdam: Nijgh en Van Ditmar, 1973.

Zhou, Xinyue, Constantine Sedikides, Tim Wildschut and Ding-Guo Gao. "Counteracting Loneliness: On the Restorative Function of Nostalgia." Psychological Sciences 19, no. 10 (2008): 1023-1029. 


\title{
$4 \quad$ Breaking the Silence
}

\begin{abstract}
During the 196os, television allowed historian Loe de Jong to shape a collective memory of the Dutch as heroes who suffered German barbarism during the Occupation. Thus, decolonization was unremembered. In 1969, a VARA television interview with veteran Joop Hueting caused a public outcry by detailing Dutch atrocities during decolonization. The official inquiry that followed, and the decision to publish a collection of official documents, only furthered the process of unremembering. Hueting's interview inspired some veterans to pen realistic novels of the conflict, as well as the first academic study of Dutch mass violence. The role of the press was ambiguous. Historians failed to engage with the subject, but the public television broadcaster VPRO aired a serious documentary about decolonization in 1976.
\end{abstract}

Keywords: decolonization, unremembering, Hueting interview, Loe de Jong, collective memory, Dutch East Indies

We have already seen how Olick argues that changes in technology can lead to changes in collective memory. Connerton argues that collective remembering will change when a transformation in communication comes through the introduction of new technology. ${ }^{1}$ Erll argues: "TV events sometimes prove to be landmarks and turning points in the development of [...] memory discourses." Raben argues that such turning points took place by means of Dutch television between the mid-196o and mid-1970s. ${ }^{3}$ The written word, as the chief vehicle of mediated collective memory, was seriously challenged by the new media. While photography, radio and cinema already provided alternative forms of mediation, television began

1 Connerton, How Societies, 75-76.

2 Erll, Memory, 139.

3 Raben, "Dutch Memories," 103.

Doolan, P.M.M., Collective Memory and the Dutch East Indies. Unremembering Decolonization. Amsterdam: Amsterdam University Press 2021 DOI: 10.5117/9789463728744_CHO4 
to accede to a position of dominance. The supplementing of literature with television meant a partial shift from inscription to performance and spectacle. Ironically, offering new ways of speaking meant a return to the oral. In television documentaries, the interview became a primary mode of re-presenting traces of the past. These living traces, the witnesses and participants in historical events, allowed the collective to draw close to the raw past. Combined with original film footage, the collective could experience a pseudo-witnessing of the past itself.

Marshal McLuhan suggested that "any new means of moving information will alter any power structure whatever." ${ }^{\prime 4} \mathrm{He}$ argued that the advent of television was bringing about "a world [...] in which everybody is so profoundly involved with everybody else." This created a brand new world of "allatonceness," where different people in different places could experience events as "a simultaneous happening." Television reduced time and place to that "allatonceness." The television event being unique, with no rewinding, skipping forward or re-watching, had the force of a new ritual.7 Raben argues that the absence of television in the 1950s had reduced the opportunity to "produce "memory."”8 But in January 1969, two decades after the ending of the Indonesian War of Independence, as historian Jan Bank puts it, "television [...] broke the silence around this subject."

\section{The Hueting Interview}

\section{Prelude: De Bezetting}

Three days after the ending of the German occupation of the Netherlands, the Dutch government founded a national institute for documenting the war. In 1955, this institute tasked Loe de Jong with writing a definitive history of the nation during the war years. Between 1969 and 1988 his Het Koninkrijk der Nederlanden in de Tweede Wereldoorlog (The Kingdom of the Netherlands during World War Two) would appear, spread over 27 volumes, filling over 16,00o pages. 
At the beginning of the era of Dutch television, between 1960 and 1965 , De Jong presented a 21-episode documentary series on the war, called De Bezetting (The Occupation). When it started, 20 per cent of Dutch households owned a television, but this grew to nearly 80 per cent by the time the series ended. With only one channel in the Netherlands, De Jong was guaranteed a massive audience for each episode. ${ }^{10}$ Indeed, the series convinced many to buy a television and the streets of the Netherlands emptied on evenings when De Jong was due to offer his "pontifical performance." ${ }^{11}$ The programme turned him into a public figure, ${ }^{12}$ earning him the unofficial epithet "national history writer."13 In Wesseling's words, De Jong became "a national hero, the unassailable guardian of the tree of knowledge." ${ }^{\prime 4}$ As the streets emptied and the citizens settled before their televisions to receive instruction from their national teacher, each episode took on an "allatonceness" ritual character, becoming in Jo Tollebeek's words a "ceremonial broadcast" that strengthened the feeling of being one community. ${ }^{15}$

Frank van Vree describes De Bezetting as "a national monument, considered by both left and right as the truthful history of war and resistance." He argues that De Jong represented the war as a period of heroism, with the dramatic narrative emphasizing the battle between humanity versus barbarism, good versus evil, with individual and group memories submerged into a national memory of collective destiny and with no place for exceptions. ${ }^{17}$

Three of the episodes covered the Dutch East Indies. The seventh episode in the series, broadcast in 1961, provided a critical overview of the imperial adventure, with images of hunters, peasants in rice fields, Buddhist temples, a gamelan orchestra and dancers. Dutch companies build modern plantations for sugar, tea, tobacco and rubber and they mine for oil and tin. De Jong teaches the nation that these were not philanthropic institutes, but were interested only in profit and that profit left the colony and was sent abroad. The Dutch brought trains and airplanes, schools and hospitals, but De Jong emphasized that the main thrust was the penetration of the colony by Dutch

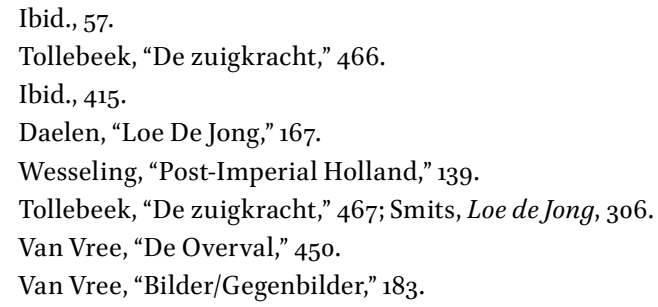


business interests. In one interview a highly placed former civil servant of the colonial administration tells that all honest Indonesians, deep in their hearts, wanted independence. ${ }^{18}$

De Jong included a short account of the rise of Indonesian nationalism before the war and a summary of the repressive measures taken by the Dutch. He mentioned that most Dutch citizens were uninterested in the colony but regarded the idea of an independent Indonesia as absurd, with the leftist parties forming the exception. In his account of the Aceh War, De Jong showed a number of photographs that demonstrated the results of Dutch violence, the same photographs that had appeared in Nieuwenhuys' Tempo Doeloe. Bijl argues that De Jong's programme released these photographs from compartmentalization, permitting them to be "framed by a larger historical narrative" so they could "function as icons of a certain phase in Dutch colonialism." ${ }^{\prime 19}$ By reframing these photographs, De Jong, according to Bijl, integrated them into the "imagined mnemonic community" of the nation. $^{20}$

However, we should not exaggerate the immediate impact of De Jong's remediation of these images. These were just three images, from 1,908 included in the series. ${ }^{21}$ His entire account of the Aceh War took less than 20 seconds. The camera lingered over each of the images for only five seconds each. The dead bodies are indistinct or even cut from the frame. The baby, in the photograph of the massacre, remained almost indiscernible. Furthermore, in the newspaper reviews of the programme, I have been unable to find a single reference to these photographs. Rather than becoming immediate icons, as Bijl suggests, their impact seems to have been negligible.

The following episode of De Bezetting covered the growth of Japanese militarism and the attack on the Dutch East Indies, while the sixteenth episode covered the Japanese occupation. Indonesian nationalism is touched upon and the condition of the Indonesians during the Occupation is briefly covered. De Jong mentioned that for the majority of Indonesians, the war that the Dutch fought against the Japanese was not their war. This would become of fundamental importance when De Jong returned to the subject decades later. This episode ended with the surrender of the Japanese and the

21 "Nu ook Duitse tv de documentaire 'De Bezetting': Dinsdag a.s. de laatste aflevering," Limburgsch Dagblad, 1 May 1965. 
outburst of the Bersiap. De Jong closed this episode by calling his audience to extend their sympathetic understanding to those who were forced to repatriate during the post-war violence. The period from 1946 to 1949 is ignored.

De Bezetting created a patriotic collective memory for the Netherlands. In its coverage of the East Indies, a great deal is unremembered. As Van Vree argues, De Jong presented exclusively a Dutch point of view. ${ }^{22}$ There was no attempt to include Japanese or Indonesian (or German) perspectives. Even the Dutch viewpoint was limited - of the thirteen people interviewed during the three episodes on Indonesia, eleven are military or government leaders. ${ }^{23}$ Most obviously, decolonization was ignored. The three episodes created an uncomplicated collective memory that represented the good Dutch nation as the innocent victim of aggression. They functioned as a tool of unremembering decolonization.

Nevertheless, in the seventh episode De Jong did include a potential critique of colonialism in his depictions of Dutch violence during the Aceh War. His remarks on the Dutch search for profit and the shortsightedness about Indonesian nationalism were critical. This provided the potentiality for remembering. Most importantly, his negative view of colonialism and its impact on the native population and his short account of the rise of Indonesian nationalism since the 1920 implied a connection between developments within the colony during the interwar years and the violence that followed World War Two. This potentiality would be realized in De Jong's main work, more than two decades later, and have a great impact on the memory wars surrounding decolonization.

\section{Allatonceness}

The unremembering that dominated Dutch society was transformed on Friday, 17 January 1969. That evening, viewers of the VARA Broadcasting Association television programme Achter het Nieuws (Behind the news) witnessed an interview with former conscripted soldier Joop Hueting. The previous month the newspaper De Volkskrant had published an interview with Hueting about his experiences of Dutch war crimes in Indonesia. The article led to little reaction. The impact of Hueting's interview in Achter het Nieuws would be on a different scale. 
In 1969, the Netherlands had only two television channels, ensuring a large public for Hueting's interview and a large "allatonceness" effect. The number of households owning a television had steadily risen. ${ }^{24}$ Bank argues that Achter het Nieuws director Herman Wigbold belonged to a new generation of journalists attracted to the idea of broadcasting current affairs via the new medium. ${ }^{25}$ It was this new medium, not newspapers nor the works of historians, that highlighted Dutch war making in Indonesia.

During the broadcast, VARA began to receive telephone calls, mostly from irate viewers expressing their rage at Hueting's statements. In total, VARA received 841 reactions -51 per cent simply negative, 28 per cent positive, 11 per cent critical and 10 per cent anonymous threats. In the coming weeks, no less than 460 articles appeared in ten national newspapers commenting on the programme. Hundreds of letters to the editors appeared in national and local newspapers. Seldom had a television programme been the catalyst for the release of so much emotion. ${ }^{26}$

What shocked the public was Hueting's revelation concerning the conduct of Dutch troops ${ }^{27}$ :

I participated in war crimes there. [...] [T]o give a few examples, I can mention that kampongs were riddled [with bullets] - where no one could see the military necessity at the time - that interrogations took place where torture was used in the most horrible way, in which the military necessity was difficult to find - that acts of vengeance took place, in which the military necessity was also not to be found. For instance, just to tell you, we had prisoners and these prisoners were often shot dead and the phrase used was "Go take a piss," after which they would turn around and be shot in the back. (10)

Hueting added: "Those were not incidental examples - that was the normal state of affairs" (10). For nearly 20 minutes he continued: while being under enemy fire, prisoners would be taken and killed. "That is a clear example of a war crime," he added (11). There were soldiers who would spot a farmer and "bang - he would be shot dead" (11). In what would become an oft-quoted

24 Bank, “Televisie," 57.

25 Ibid., 66.

26 Van den Born et al., "De Excessennota," 172.

27 Achter het Nieuws, VARA, 17 January 1969. The complete text of the programme was published: De Graeff, Nederlandsch Indië 1945. All references are to this published text. 
passage, Hueting described how two soldiers entered a house in a kampong (village), opened fire and then he himself entered the house:

I saw there, in the twilight, 15, 20 people - women, children and men, squatting down in a heap. And when I got used to [the light] I saw the blood spurting from arteries, the screaming, the death agony and death cries from the people in that little house. And the lads outside shouted at us: "Hey, will you watch out lads, because you shot through the wall and almost hit us." (11)

Hueting described interrogation practices: "After the hitting and kicking sometimes the telephone was used, when the wires would be attached to the genitals and then a current would be released [...] and the people would shrivel up from the pain and pass urine" (12). He described one of the most upsetting incidents that he had witnessed:

\begin{abstract}
[A] rope was taken and that was tied around the ankles of the man and then the rope was thrown over the beam that supported the interior gallery of the house. The rope was pulled on one side and on the other side the man - ankles above, head below. First the rope was gently released, until he came with his head on the concrete floor of the gallery, and then harder, until the blood was coming from pretty much everywhere and a sort of cracking sound came from his head. He died in a really sick way. (12-13)
\end{abstract}

He claimed "many thousands" of Indonesians died like this (13). Hueting explained that the silence that engulfed these events was the result of two processes: the former soldiers or veterans did not believe in "hanging out the dirty laundry" and it was not in the interests of the politicians from that time to have these issues in the limelight (16). Asked if war crimes had been committed, Hueting answered: "[I]t happened on a large scale" (16). Furthermore, the responsibility lay not with the soldiers themselves, but with the political leaders and with the military commanders (17).

The programme finished with the words of Herman Wigbold: "[T]he sadist within oneself, must know that war crimes do not need to remain unknown. In particular, coming to terms with the past needs to commence. Over the entire Indonesian drama, there hangs in our country a haze of mysteriousness" (20). 


\section{Sequels}

The overwhelming reaction to the programme led the producers to broadcast an extra, 90-minute-long programme in which other veterans of the conflict got the opportunity to share their stories. The Achter het Nieuws of 25 January 1969 opened with Wigbold referring to Dutch "plundering, burning, torturing and murder." This introduced a new, sharp tone to the decolonization discourse that was still in its infancy. A pastor explained: "War crime is not just a question of the German mentality or the American mentality. You find war crimes in the Netherlands, too" (29-30).

Eleven veterans shared their memories. They told of Dutch soldiers burning villages to the ground, herding men together and shooting them, forcing men to dig their own graves and then shooting them, children shot, women raped and prisoners massacred. They described interrogations in which ears and noses were cut off. They told of systematic plundering. One veteran read entries from his own diary in which villages are burnt, prisoners tortured and shot (6o-63). When asked if he often thinks back to that time, he answered: "Ah, it wears one down gradually. I haven't looked in this diary for 20 years. But now, with this affair, I've looked through it in order to select some passages" (64). For these veterans, the broadcast of the interview with Hueting seems to have been a catalyst.

A participant tells of an incident in April 1946 in which the military police of the KNIL (Royal Netherlands East Indies Army) abused and massacred nearly 70 prisoners before dumping their bodies in a river. Dutch soldiers and officers did not intervene even though they themselves had experienced similar "Gestapo methods" (44) in Holland. He then says that he had written about the incident for Het Parool, but that the account had never appeared in the newspaper, and that he had sent a copy to the secretariat of the Labour Party and that the issue had been raised in parliament but it had simply disappeared (44).

Pastor Hildering tells of massacres and rapes that he reported to the leadership of the Dutch Reformed Church. He is asked to explain how former Prime Minister Drees had claimed that during his time as prime minister he had only ever heard of two other such cases. Hildering answered: "That is incomprehensible to me, because these accounts were openly published" (57). He was correct because, as we saw in Chapter 2, his testimony was reported in the NRC Handelsblad in 1949.

Another pastor tells of an incident in which soldiers were commanded to shoot "all lads older than sixteen and all men." Some of the soldiers came to him and shared their doubts, asking, "What is the difference between 
what happened in Putten and what we have now done?" He concluded: "I couldn't discover any difference." At this point, Wigbold, asked, "Why is this only now coming to light, 20 years later? Did we know it, or did we not want to know it?" Hildering suggested: "It seems [...] that many of these things have been hidden. But I have to deny that. [...] I have here a couple of books in which the things that happened are published" (67).

Two days later, Achter het Nieuws broadcast a third programme. Former Prime Ministers Beel and Drees refrained from attending. Nevertheless, some of the leading actors in the conflict did attend, including Schermerhorn (prime minister during 1945-1946 and former chairman of the Commission General for Indonesia) and Thomson (brigade commander of $7^{\text {th }}$ Division and temporary chief of the general staff of the Dutch army in Indonesia). Schermerhorn expressed his fear that the previous programmes created generalizations regarding the behaviour of soldiers (74). De Graaf, a spokesperson during the conflict for the ruling Catholic People's Party (KVP), questioned the use of the term "war crimes" (74-75). Thomsen complained that the two programmes "provoked memories of these people [...] who are deeply touched, things that cannot be described in words" (78). Thomsen blamed the makers of Achter het Nieuws for provoking disturbing memories.

Another participant, Professor Verkuyl, disagreed with the pleas for unremembering, expressing gratitude that these things "which we all know about, and that live latently within us, now at last can be spoken about openly" (80). Van Mierlo, leader of the liberal party D66, agreed that "a public national secret was repressed," adding that questions had been raised by Frans Goedhart in parliament and that articles had been published in the press but there had been no follow-up (88). However, Thomsen maintained that Hueting and the programme makers made it seem that everyone who was in Indonesia had earned the label "war criminal" (88).

A veteran of the conflict had at last spoken out publically. Dutch society had failed to assimilate into its collective memory the memories of its veterans. These had become silent, latent memories. Bourke argues that combatants feel a need to bear witness and find "a legitimate narrative that can 'place' the self in a way that is both coherent and convincing.".28 Assmann and Shortt claim that traumatic cases call for a period of latency, an interval before society is willing to face the memory of its violent past. What sets the stage for confronting its painful memories is changes in political regime, changes in social frame, generational changes or media 
events. ${ }^{29}$ The period of latency had now passed. Television had provided a new way of speaking for veterans to construct a new narrative.

\section{Why Now?}

Halbwachs argued that it is in society that individuals "recall, recognize, and localize their memories. ${ }^{30}$ Hueting's remembering was not exclusively an individual matter. Rather, changes in society shaped a new phase of collective remembering. Hueting had already tried to publish his views about the conflict in the 1950s. Both the NRC Handelsblad and Het Parool had refrained from publishing the material. ${ }^{31}$ It was, at that time, too difficult to contest collective unremembering. The editor of Het Parool wrote to Hueting and invited him to a meeting in which he explained why he felt the moment was not right. ${ }^{32}$ The editor of the NRC Handelsblad wrote twice to Hueting, explaining: "When it comes to expressing criticism of cruel deeds that occurred during pacification of areas, one needs to practice prudence." 33

In a television appearance in July 2012, when asked about his motivation for giving the interview in 1969, Hueting answered that it was linked with the discussion regarding French atrocities during their war against Algerian nationalists. He found it strange that in the Netherlands people were discussing the behaviour of the French army, yet for two decades they had ignored discussing atrocities perpetrated by their own troops in Indonesia. ${ }^{34}$ This is consistent with what Hueting said at the time. When asked for his reasons for coming clean now, he had said, "You can better talk about war criminals and about war crimes committed by the French in Algeria, by the Germans in West and East Europe and by Americans in Vietnam."35

The war in Algeria was at its height during Hueting's first attempt to publish in the late 1950s. The French conceded defeat and recognized an independent Algeria in 1962. In a replay of the Dutch experience, large numbers of French citizens were repatriated. Concerns regarding the widespread use of torture by the French military had given rise to a growing anti-war movement. During the late 1950s and early 196os, the Dutch press of all

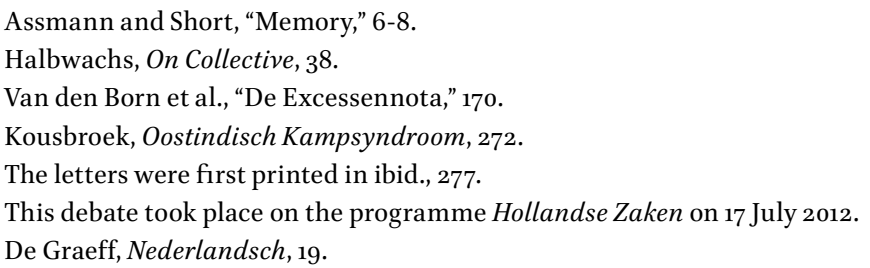


political persuasions, as well as the national radio, carried reports that the French military in Algeria were guilty of widespread torture and murder. ${ }^{36}$ Dutch newspapers reported on the people displaced, imprisoned, interred and killed..$^{37}$ The actions of the French radical military organization, the $\mathrm{OAS},{ }^{38}$ were widely reported as being acts of murder or terror. ${ }^{39}$

Gillo Pontecorvo's anti-colonial film The Battle of Algiers was released in 1966 and, despite being banned in France, was nominated for three Oscars and won the Golden Lion award at the Venice Film Festival. Joris Ivens had been a member of the Venice jury. ${ }^{40}$ Ivens must have recognized the similarity between Pontecorvo's fictional documentary style and his own film, Indonesia Calling. The reviewer of the Nieuwsblad van het Noorden wrote that the decision in Venice was evidence that the jury had been courageous by refusing to capitulate to French pressure..$^{41}$ The liberal Algemeen Handelsblad wrote that Pontecorvo's film fully deserved its award. ${ }^{42}$ A reviewer in $D e$ Tijd pointed out a new trend in attacking colonialism in films, specifically "the terror of the Portuguese and French."

In an act of unremembering, no reviewer drew the obvious parallel to the Dutch East Indies. The year after the Hueting interview, Paul Haimon wrote in the Limburgsch Dagblad that the French were worried that the film would "open slow-healing wounds" and wondered how the French could have been so blind as to not see the inevitability of decolonization. But, he

36 “Algerie," Friese Koerier, 3 January 1958; J.J. Buskers, "Benane Mahfoed," Het Vrije Volk, 23 May 1959; “De Franse Militairen in Algerie," Gereformeerd Gezinsblad, 23 December 1959; "Report van Rode Kruis: In Algerie wordt nog wel gemarteld," Het Vrije Volk, 5 January 1960; “De misdaad," Friese Koerier, 21 May 1962; “Naar een nieuwe ideologie," Nieuw Israelietisch Weekblad, 15 May 1964; "Wij zijn geen stelletje misdadigers," Leeuwarder Courant, 13 May 1967; APN Nieuwsbericht, 12 April 1959.

37 "Oorlog in Algerie kostte redes ca 200,00o doden," Gereformeerd Gezinsblad, 20 May 1961; "Na zeven jaar leed ... Vrede," Algemeen Handelsblad, 19 March 1962; "Bestand in Algerie," Gereformeerd Dagblad, 20 March 1962.

38 Organisation armée secrète, a French far-right dissident terrorist organization that fought against Algerian independence during the Algerian War (1954-1962).

39 "De Gaulle: De Algerijnse beproeving nadert zijn einde," Algemeen Handelsblad, 26 February 1962; Jo Manassen, "Mohammedanen rekenen op einde OAS-acties," Het Vrije Volk, 21 March 1962; "Terreur in Algerie door OAS-agitatie opnieuw ontbrand," Limburgsch Dagblad, 21 March 1962; "Ineenstorting van OAS-terreur un volledig," De Waarheid, 28 June 1962.

40 “Joris Ivens in Jury in Venetië," De Tijd, 2 September 1966.

41 "Film Algerijnse oorlog wint hoofdprijs Venetië," Nieuwsblad van het Noorden, 12 September 1966.

42 "Deining in Venetië over filmprijzen," Algemeen Dagblad, 12 September 1966. 
never questioned why the Dutch couldn't see this either. ${ }^{44}$ That the Dutch press could discuss French atrocities while remaining silent regarding their own, was thought by Hueting to be peculiar. These reactions to Pontecorvo's film are a case in point.

Hueting must have been aware of the controversy surrounding Pontocorvo's film, as it was widely covered in the Dutch media. Yet, it is doubtful that he had seen the film. Despite the widespread reviews, it was not until 1970 that it had its Dutch premiere. ${ }^{45}$ Peter Bueren of De Tijd is surely guilty of naivety for writing, "[I]t is one of the most incomprehensible things in the world that this magnificent document has only now reached the Netherlands. ${ }^{m 6}$ It took nearly another year before the film entered regular cinemas in the Netherlands. ${ }^{47}$ One explanation offered was that film distributors were afraid that the film would not appeal to a Dutch audience. ${ }^{48}$ Still, every reviewer blindly missed the link with the Dutch East Indies. In 1975, the reviewer in Het Vrije Volk expressed his joy that the film would be shown by a film society in Rotterdam, mistakenly believing that this would be its first showing in Rotterdam. He complained that the film had suffered from censorship in some countries (no mention of the Netherlands) and suggested that some scenes of violence begged a comparison with South Africa. ${ }^{49}$ Again, no mention made of the Dutch East Indies. It was this type of unremembering that Hueting was fighting.

Furthermore, the Dutch themselves had only just been forced to bring an end to their final phase of decolonization in Asia. In the year that France had lost Algeria, 1962, the Dutch had lost West New Guinea. Relations between the Netherlands and the Republic of Indonesia continued to sour throughout the 1950 s as the Indonesians coveted Dutch New Guinea and the Netherlands refused to relinquish it. In 1962, Indonesia annexed West New Guinea. Lijphart published his account of this event in 1966 with the telling title, The Trauma of Decolonization. As we saw, he argued that the Dutch futile attempts to retain West New Guinea were based on "entirely subjective and psychological" desires, namely: "the search for national

44 Paul Haimon, “De slag om Algiers," Limburgsch Dagblad, 16 April 1970.

45 Henk ten Berge, "Mr. Cinemanifestatie moe maar tevreden: Gillo Pontecorvo De Beste," De Telegraaf, 2 February 1970.

46 Peter van Bueren, “Zelfs na vier jaar blijft de 'Strijd om Algiers' actueel," De Tijd, 4 February 1970.

47 "Film: De Slag om Algiers," De Waarheid, 23 October 1970.

48 "Dit moet u zien," De Tijd, 23 October 1970.

49 "Film over gruwlijke bevrijding Algiers," Het Vrije Volk, 11 April 1975. 
self-esteem, feelings of moral superiority, egocentric altruism, and deep resentment against Indonesia. ${ }^{50}$

Dutch society was changing in the 1960 s, and this had consequences for the production of collective memory. ${ }^{51}$ Mid-196os Amsterdam had become the birthplace of a colourful new anarchist group, the Provos. This anti-authoritarian movement took its name from its deliberate social provocations that were widely covered in the nation's media. At the same time, the Vietnam War had become a symbol of protest. Daily newspaper and television coverage of the Vietnam War had brought the issue of war atrocities before the public's eyes. The year 1968 was one of chaos and potential change. In February 1968, the West German radical student leader Rudi Dutschke made a well-publicized visit to Amsterdam..$^{2}$ The Dutch witnessed on their televisions the students of Paris rebel in May, followed by the crushing of the Prague Spring in August. Meanwhile, the Dutch government's decision to penalize students for using the slogan "Johnson - War Criminal," while dropping charges against an anti-war philosopher from the University of Groningen, caused heated and emotional public debate. ${ }^{53}$ In April 1968, Herman Wigbold presented an edition of the television programme Achter het Nieuws dedicated to the polarized views concerning the Vietnam War.

It is against the background of the controversies unleashed by two colonial wars - the Algerian War and the American intervention in the Vietnam War, as well as instability brought about by potential radical social change, that Hueting decided to recall his own country's unremembered colonial war. ${ }^{54}$ Changes in media provided the means for contesting the established unremembering.

\section{The Role of the Public}

One must also ask - why had the Dutch public been willing to accept a process of unremembering? One can argue that the lack of interest in decolonization mirrored an equal lack of interest in the colonization project itself. Remco Raben admits that a lot more work needs to be done by historians in order to adequately measure the impact of colonialism on the conscious

\footnotetext{
50 Lijphart, The Trauma, 288.

51 Raben, "Koloniale Vergangenheit," 94-95.

$5^{2}$ Van de Maar, Weltrusten, 105-106.

53 Ibid., 106-121.

54 Van Galen adds another factor: "the bloody defending of Portuguese colonialism in Africa." Van Galen, Afscheid, 523 .
} 
lives of the Dutch citizens. The appeal of empire may have been limited, leading Raben to conclude that, probably, "empire was experienced as an indispensable daily presence only sporadically."55

Another reason for the lack of interest in decolonization might be that within Dutch society in general, acts of public national self-criticism were rare. Rudy Kousbroek, born and reared in the Dutch East Indies, claimed that Dutch people criticize how other nations deal with their past, but use another measuring stick when judging themselves. ${ }^{6}$ He argued: "It is a well-known phenomenon that every individual, every group, every land, is more forgiving towards oneself than towards another" but among the Dutch, "the phenomenon [...] is out of control."57

We are reminded of Ricoeur's discussion of how memory is bound up with the "fragility of identity." ${ }^{8}$ This suggests that nations are more likely to recognize themselves as victims, rather than perpetrators. The primary collective memory of the recent past for the Dutch public, as Van Ginkel states, was the national myth of resistance against the evil of the Nazi occupation (nationale verzetsmythe). ${ }^{59}$ Frances Gouda argues that the Dutch historical imaginary had framed Anne Frank and Sukarno "as icons of memory." Anne Frank served "as a foil for lingering questions about the varying degrees of Nazi collaboration among a sizable proportion of the Dutch population." Sukarno served as an icon of memory that "stifled any honest postcolonial assessment of Dutch complicity in the technologies of oppression." 60

Those who had given their lives in the struggle against fascism were commemorated in acts of ritual remembering. ${ }^{6}$ This national myth made it difficult to believe that the forces of good had also committed rape and murder in Indonesia. The ritualized remembering of the years from 1940 to 1945 created a screen behind which the years from 1945 to 1949 were occluded. Just as we have previously seen with Loe de Jong's De Bezetting, the exclusive focus on the pain of the years from 1940 to 1945 caused the memory of the years from 1945 to 1949 to be unremembered. Nevertheless, the advent of television provided a new means of creating representations of the past and constructing collective memory.

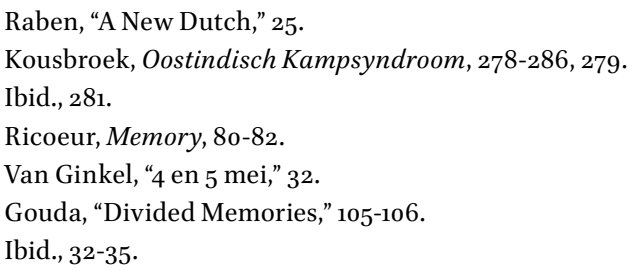




\section{Political Impact}

The representation of decolonization provided by Achter het Nieuws had an immediate impact. Henk Wesseling claimed it "was a bombshell." ${ }^{\text {2 }}$ Van Doorn and Hendrix agree that it "struck like a bomb." ${ }^{63}$ The conservative newspaper De Telegraaf might have aired the views of many when it responded to Achter het Nieuws with, "it is [...] blown out of all proportions" and labelled Hueting's interview "a sick act." ${ }^{\prime 64}$ However, the government agreed that the issue of excesses (the term "war crimes" was avoided) should be investigated. Jurist and historian Cees Fasseur was tasked with leading a group to research cases in which Dutch soldiers had been investigated for breaking the law. To his surprise, his fellow members on the commission were all colonials or ex-military officers who had served in the Indies. None were enthusiastic about the job they had been given. Furthermore, Prime Minister Piet de Jong requested that the investigation be finished within three months. ${ }^{6}$ Under these circumstances Fasseur could do little more than read through the 12,000 dossiers involving court martials in Indonesia, in the archives at the Supreme Military Court in The Hague. ${ }^{66}$ As he himself put it: "Like a sort of accountant, without mixing in emotions, I was then able to write that work in record time. ${ }^{n 7}$ Fasseur was able to dismiss over 10,000 cases, these being no more than misdemeanours such as traffic violations. ${ }^{68} \mathrm{He}$ eventually narrowed the cases to under 600 . The Excessennota (List of excesses) that he published lacks any interpretation of the data. For a large part, it simply lists these cases, stating place and time, the offence, the verdict and a short summary of the case. In most cases, the accused was found not guilty. In just 42 cases, a soldier was found guilty of murder. The Excessennota was published in mid-1969 with a foreword from Prime Minister De Jong, who felt comfortable enough concluding, "The government regrets that excesses took place, but maintains the position that the armed forces in general behaved in a correct manner." ${ }^{\prime 6}$

Fasseur's research had been limited to studying those cases that had come before the military authorities. The cases that Hueting had described,

\footnotetext{
62 Wesseling, "Post-Imperial Holland," 140.

63 Van Doorn and Hendrix, Ontsporing, 317.

64 Quoted in Van den Born et al., "De Excessennota," 163.

65 Ibid., 173 .

66 Bank, De Excessennota, 25.

67 Interview in Meijer, Oostindisch, 106.

68 Bank, De Excessennota, 25.

69 Ibid., 32.
} 
however, were not included in the Excessennota. The Excessennota included an overview of newspaper and periodical articles from 1945 to 1950 that referred to excesses by Dutch troops. This was a double-column annotated list covering 27 pages. ${ }^{70}$ Yet no one called for a parliamentary inquiry and no member of the historical profession protested. Even the public, briefly stimulated by the Achter het Nieuws broadcasts, seemed to lose interest. The publication of the Excessennota and its debate in parliament did not make it to the front page of the newspapers. ${ }^{71}$ Fasseur concluded that war in Indonesia was still "a national trauma. ${ }^{72}$ Importantly, decades later he admitted that the term "war crimes" had been impossible to use, the entire exercise being no more than a government note that needed the approval of the cabinet. ${ }^{73}$ Thus, the Excessennota, rather than being a vehicle for remembering, worked as a tool of unremembering.

\section{Literary Impact}

Television provided the platform for the renewal of memory. Literature provided further renewal. Although professional historians shunned the subject, veterans were not so timid. We have seen how Job Sytzen wrote novels during the 1950s based on his experiences. Months after Hueting's interview, three new novels were published, written by men who had served in Indonesia. None shied away from representing their memories of excesses.

\section{Jan Schilt}

Jan Schilt served in West Java from November 1946 until March 1950 - a remarkably long period for a conscripted soldier. His Soldaatje spelen onder de smaragden gordel (Playing soldier in the emerald belt) begins with an epitaph, taken from Stanislaw Lec, that sums up the main theme of the book:

\section{Most people are murderers}

They kill a human; the human in the self ${ }^{4}$

Within the first pages, we find Dutch intelligence personnel torturing a prisoner and we have the first of many shootings of prisoners (9-10). The

Van den Born et al., "De Excessennota," 173. 
main character delivers a prisoner to the intelligence service, then has sex with a young woman who has already slept with his friends (15-17). Later, one of his friends discovers that he has caught a venereal disease (32). Much of what Schilt writes supports Hueting's experience - soldiers regularly shoot and bayonet prisoners $(23,70,129,160)$; they burn villages to the ground (23), they beat and torture prisoners $(9,118,125)$. Schilt conveys the boredom of army life in the jungle. Soldiers play cards and chess, drink and lay around doing nothing. They get malaria and sexually transmitted diseases. They listen to the radio, dance with each other, sing together, eat bad food and smoke bad cigarettes. They watch films in the local cinema, get drunk and visit prostitutes. Their conversations are critical of the Dutch authorities. During one such conversation, a soldier says: "Look, we'll have to recognize the republic sooner or later, especially because America and good old England want that, so what, what are we doing here?" (41). Another answers: "Just hang on in there for a while, until the rotten capitalists have taken their loot out of the Indies; that's why we're bungling around in the mire" (41). Another adds, "nicely dressed men in expensive suits who make these dirty cigarettes and these dirty politics" (41).

Anger is directed towards those powerful groups in the establishment who sent these young men to fight in a dirty war. A soldier reflects:

How many evenings had they wasted in that poxy land? A year has 365 days, so 730 at least, plus a bit more. And still, hanging around, smoking, not talking, talking, playing cards, staring into the dark and listening to the crickets when on sentry duty, getting plastered drunk, going on patrol, going to one of the baboes [women], watching some poxy film, sleeping, being tense, relaxing, now yah, relaxing (57).

Schilt captured a complaint that we will increasingly hear from veterans - they wasted some of the best years of their lives because their country demanded it, yet were never properly thanked. At one point, a journalist visits them. A soldier suggests to him: "Make a report now for your newspaper and set the truth down, that we want to go home, that it's a lost cause, that we are being messed around with and that we still don't see the point of it" (111). Schilt represents the war in Indonesia as a matter of young Dutch men sent by authorities to fight in a pointless, unwinnable conflict while the home front consumed fake news.

That the young soldiers were brutalized is clear. The main character and a friend, during a week off, hitchhike to Bandung, where they get drunk, pick up girls and pay for sex, then get a lift to Batavia where, after getting 
very drunk, the main character kicks a dog to death (88-95). Soldiers kick a prisoner to death (118). They randomly capture four villagers. As they beat them, the women of the village cry loudly, screaming children clinging to their mothers. The prisoners are innocent, but the soldiers lead them to a field "like lambs being led to the slaughter, the soldier thinks" and shoot them (160). During an assault on a kampong (village) they find a blind, sick old man, together with two old women. They drag the man out, kicking and beating him as the women scream and beg for mercy. The main character recalls the words of the commander-in-chief, General Spoor: "Be aware that you are the bringers of justice and security to a people suffering from terror and oppression" (125). He reflects: "We all suffer from some form of terror, and that's why we inflict it on others when we get the chance" (125). They kill the old man, as well as another prisoner (129).

For the soldiers, the war comes to an unexpectedly sudden end. Demobilization in Holland is quick - the veterans each get a free train pass (192). The main character walks through his village and enters his home. His mother, crying, embraces him, and he wonders what is he doing here, suggesting the disorientation that returned soldiers felt (196). An unarticulated narrative is implied but left unspoken, the cold homecoming in which memories will be buried in silenced.

Schilt's protagonist is referred to as "the soldier." There is nothing special about him, except his exceptional circumstances. He is brutalized, though his reflections show us that he retains his humanity. The responsibility lies with those in authority who created the circumstances under which excessive violence becomes a necessity. In a television interview in 1993, Schilt referred to the war as a "dirty war" and qualified the behaviour of the Dutch, explaining that they were not a wild group of bandits, yet they killed prisoners, as described in his book. ${ }^{75}$

\section{Jacob Zwaan}

Jacob Zwaan volunteered to go to fight in Indonesia. In his novel, a main character, Jaap Koorman, has volunteered for the army, "in order to liberate the Indies" and "resist the terror" of the Japanese. By the time they arrive, the Japanese have surrendered and the volunteers have to fight the Indonesians. Koorman will encounter "barbaric cruelties, bacchanalia and erotic excesses" and his initial enthusiasm will be replaced with doubt when he witnesses 
the interrogation techniques of the Dutch Intelligence and Security Service, which make him think of the Germans. ${ }^{7}$

A character called Rene Verberne encounters a woman in the army post; he pushes her into an armoured car and has sex with her. Immediately afterwards he thinks of his father, a "puritanical inspector of the Rotterdam vice squad" (22). During free time, soldiers visit strip clubs (50). They worry that God will condemn them (55-57). Over time, they get used to it and they have sex with Dutch, Indisch and foreign prostitutes (105-116), with nurses (168), with a primary school teacher (169-184) and with the young daughter of a banker (229). A soldier comments; "Eros and Mars always walk hand in hand" (168). The narrator comments: "In an attempt to enjoy what there was to enjoy before the flame of revolution would irrevocably scorch them, they offered their money and their bodies in a possessed drunkenness of Bacchus and Eros" (173).

Like in Schilt's work, there is plenty of violence, though Zwaan injects ruminations regarding the morality of such actions, and continually draws parallels with the Nazis. Dutch soldiers burn kampongs $(32-36,79-82,137)$, rape villagers (138), beat, torture and kill prisoners $(78,79,91-98)$. One soldiers remarks: "I can now even understand some of the reactions of the Germans" (19). Verberne thinks: "from such men, Himmler recruited the SS" (22). Some soldiers complain about "SS methods" (78). Zwaan writes that the Dutch methods have a whiff of "a certain occupier" (82). A member of the intelligence service admits that there are some who claim, "we [...] are all members of the SD [Sicherheitsdienst or Nazi Security Service] and sadists" (90). A major asks, "Maybe I'm commanding a company of the SS?" (103).

Similar to Schilt, Zwaan's soldiers show a low opinion of the political leadership. One suggests laying siege to The Hague and hanging ministers from the trees; another proposes quartering them and burning them alive (37-38). Pondering the brutality that has taken hold of these young recruits, an officer attempts to explain their behaviour:

In what sort of world have these men grown up in? They have been hunted like cattle. They've been dragged from their homes, deported and shut up in camps. After liberation, loaded onto ships and sent to a tropical land, [...] brutalized in a time of mass murder and the glorification of war. (103)

Zwaan's novel twice references Hueting's interview. Firstly, we are told, "The peloppers [a derogatory term for Indonesian freedom fighters] are 
thugs, but our reaction is just as barbaric. [...] [I]n the Netherlands they will never understand it and will only see the excesses" (18). The key word here is "excesses," a term that first enters the public discourse with Achter het Nieuws, and the publication of the Excessennota. In the final scene, four characters and their wives come together for a reunion. They turn on the television. It is 19 January 1969 . Achter het Nieuws begins and they fall silent, their glasses of wine untouched as Hueting tells his story. Their first reaction is to curse Hueting. One demands: “Why didn't the old bastard tell about how much good we did there?" Another counters, "We know damn well that Hueting is generally right." One wife jokes, "Our husbands are war criminals." That night, the old soldiers and their wives stay up later than usual, and, for the first time, the men start to tell their stories (302-304).

The brutality of Dutch soldiers and members of the intelligence service, the drinking and prostitution, the disillusionment and criticism of the political authorities in Holland - the experience was the same for the conscript in Schilt's book and the volunteer in Zwaan's. Both writers allude to the belief that war brutalizes and that those who were responsible were the leadership, not the soldier. However, Zwaan offers a further explanation, that the time they were living in was particularly brutal. The soldiers in Indonesia were raised during the economic depression, lived through the Nazi occupation and were transported to labour camps in Germany. After liberation, they found themselves again at war.

\section{Jan Varenne}

The third novel of 1969 was Eer de haan kraait (Before the cock crows) from Jan Varenne. At just over a hundred pages in length, it is a slight work, but stylistically it is the most sophisticated. Varenne does not shrink from describing brutal excesses, but the reflective tone of the narrator and the originality of some of the images soften the hard edges. Rob Nieuwenhuys concluded: "All in all, Eer de haan kraait is one of the best books about the police actions." 77

The main character is named Jenver, a reference to the author's own name - Jan Varenne. Jenver is a likable young man, whose greatest weakness is the wish to please. In the first page, we find him burning down a house for the first time..$^{7}$ Later we find descriptions of prisoners being shot $(29,31-32)$; wounded Indonesians being shot (61); electric shocks and burns inflicted upon a prisoner during interrogation (65-67); we are told that the great sport 
was plundering villages (103). Varenne describes a village surrounded and all the men rounded up, but when the Dutch soldiers fail to find weapons and fail to find the men they were searching for, they randomly take two men. When these two fail to supply information, the young officer orders them to "follow normal procedure this afternoon during routine patrol" (34). The men are shot, and in the report the officer writes, "shot during attempted escape" (35). After the shooting, the officer tries to write a letter to his mother. He gets no further than writing "Dear Mother" (35).

In another scene, the cook is watching over a prisoner. He kicks the prisoner, sticks him in a rubbish drum and fills the drum with the kitchen leftovers, covering the prisoner. The officer and other soldiers laugh, but Jenver found it too crude (50). Near the end of the story, Jenver has decided to speak up and save the lives of two prisoners. He is formulating his objections in his mind, yet he fails to speak out and the prisoners are killed (117-118).

Most violence takes place off the page. Prostitution is referred to, but is not explicit. Prisoners are harassed and killed, but there are no detailed descriptions of torture. Unlike the novels of Schilt and Zwaan, there are few political discussions, few complaints about the military or political leadership. The soldiers have a difficult task, but it has to be done.

What causes Jenver to go along with acts of brutality without protest? Why do ordinary young men become brutal killers? An answer is hinted at in one of the italicized pieces that interleaf the story proper: "By the way, with the exceptions of a few whiners, they were all great lads. I never had it so good as I did in that platoon. Like in mother's lap" (26). This need to belong to the group is described in detail. The soldiers have an evening's entertainment, a cabaret; they get drunk and sing together, eventually with arms interlocked, and Jenver becomes emotional: "God, thought Jenver, to belong, [...] that's it, [...] to love all these people, and to be loved" (47). In the foreword, Varenne explains, "For Jenver, my hero, the group always wins" (5). His motivation for writing was his astonishment that regular churchgoers and well-intentioned villagers, aristocrats and socialists, easily metamorphized into killers. He had learned that humans want to belong, they become prisoners of the group, and like rats, they remain loyal within their own rat colony (6). He represents the war of decolonization as young Dutch soldiers who, surrounded by a strange enemy in an alien environment, maintained their dignity towards each other, but reacted to the Other in the way any group would have reacted - with systemic violence.

This begs the question: If Dutch soldiers did what any soldiers would do in a similar situation, does this mean they were no different from the German soldiers who had terrorized the Netherlands? Jenver reflects that 
during the Occupation, you sometimes encountered a normal German and you realized that he was just an ordinary lad who had nothing to do with Hitler (71). In his foreword, he writes, "I personally have no reason to conclude that Dutch men, when placed into the same circumstances, would not have produced a comparable percentage of camp brutes as the Germans" (13).

Varenne's representation suggests that the Dutch military leadership was not a bloodthirsty lot, and the politicians have nothing to feel ashamed of (14). The brutal excesses were simply the result of the system. At the same time, in a clear reference to the negative reactions to Hueting's Achter het Nieuws interview, Varenne admits that he is amazed to read the denials of the excesses by people who had to know (15). Varenne concludes his foreword: "It is stupid, now that the cat is out of the bag, to sweep him under the carpet" (15).

All three novels were written from a strictly Eurocentric point of view. We never hear of any Indonesian motivations. No Indonesian character is given any depth. We never gain an insight into Indonesian thoughts. All three offer us a male point of view. Although Schilt and Zwaan criticize authorities in The Hague, suggesting that the war was fought to defend the interests of big capital, no writer applies a critical analysis to the nature of Dutch colonial rule. None suggests that the outburst of violence was the result of the inequalities bred by colonialism.

In 1978, Rob Nieuwenhuys published his critical survey of Indische literature, Oost-Indische spiegel (East Indies mirror). He referred to the three novels of Schilt, Zwaan and Varenne as attempts at "demythologizing the war." ${ }^{79}$ The three novels formed an attack on unremembering, and the politics of concealment. Margaretha Ferguson revealed that Varenne had written his book in 1951-1952 and had spent years trying, in vain, to find a publisher. The Hueting interview afforded the opportunity of publication. ${ }^{80}$

\section{Historiographical Impact}

Shortly after the Hueting interview, journalist and Sukarno biographer Paul van 't Veer, published De Atjeh-oorlog (The Aceh War). At first glance, this detailed study of the Aceh War (1871-1942) seems unrelated to a discussion of Hueting's impact. After all, such a study was the result of years of research

79 Nieuwenhuys, Oost-Indische, 455 .

80 Margaretha Ferguson, "De onvrijheid van de literatuur in Nederland," Het Vaderland, 20 September 1969 . 
predating the Hueting controversy. However, an analysis of the book's reception highlights the work of unremembering.

De Atjeh-oorlog provided an analysis of the military dimensions, as well as the ethical and political issues raised at the time of the war that the Dutch colonial government fought in Aceh, in Sumatra, on and off from 1871 until 1942. One could expect that the reader in 1969 might draw parallels between Van 't Veer's account of the Aceh War and Hueting's eyewitness testimony of the War of Independence. After all, Van 't Veer suggests that Dutch soldiers had routinely burned Indonesian villages to the ground; ${ }^{81}$ that prisoners forced to work for the Dutch died by the thousands (169); that Dutch military personnel perpetrated "indescribable cruelties" in which hundreds of women and children were massacred (174). He represented Dutch forces spending days destroying an Indonesian settlement, burning all buildings to the ground, chopping down trees, destroying gravestones (207). He described how an officer had an Aceh leader decapitated before the eyes of the victim's wife and children and kept the severed head in an alcohol solution in a glass jug (232). He listed war crimes: "arbitrary executions, the killing of prisoners, the torture of uncooperative informers, the nurturing of murderous rage, the murder of women and children and the locking up of hostages in cages" (248). Van 't Veer claimed that 4 per cent of the Aceh population had been killed in just ten years (260). In one campaign, between a quarter and a third of the population of one region had been slaughtered (269). This led Van 't Veer to compare Dutch terror with the Spanish fury in the Netherlands in the sixteenth century (272).

Van 't Veer showed that many in the home front objected to how the war was being prosecuted. He described health officers producing a report on "inhumane cruelties" (139). He described the futile attempts made to improve the deplorable conditions of forced labourers (168). Most importantly, he writes of how one ex-officer had anonymously penned a series of articles for a Dutch newspaper in 1907. The articles detailed numerous cruelties and the widespread use of terror (284-292). Van 't Veer argued that the articles were the most influential ever to appear in a newspaper about an Indisch subject, eventually leading to a parliamentary debate and an official military inquiry (284-292). Just like the Hueting interview, one is tempted to exclaim.

The book included the photograph that documented one massacre, including a baby sitting next to a group of corpses. ${ }^{82}$ We have already come across this photograph in the work of Rob Nieuwenhuys and Loe 
de Jong. According to Bijl, Van 't Veer has not simply recycled the photograph, but he has repurposed the image. On the one hand, it provides "an index of a specific event." However, by including it within a broader frame - an attack on Dutch imperialism - the photograph "gains larger iconic meanings." ${ }^{83}$ Nevertheless, few immediately saw any iconic link between the photograph from the Aceh War and more recent atrocities described by Hueting.

For the readers in 1969, the parallels must have been obvious, one would think. Here was a book demonstrating that the atrocities described by Hueting, far from being arbitrary, formed a continuation of a tradition of Dutch colonial warfare. Hueting's telling could not be seen as unique, but could be placed against a similar case of whistle-blowing in 1907. It would seem that the Hueting controversy that had dominated the news only months earlier would have been in the back (or forefront) of reviewer's minds, as they picked up another work detailing Dutch military atrocities. Consequently, if reviewers were to mention Hueting in their reviews, this would be unsurprising. Instead, in an example of widespread unremembering, we find that every reviewer without exception failed to connect Van't Veer's account with Hueting's interview.

In the communist De Waarheid, a source of irritation seemed to be the fact that Van't Veer had failed to mention Marx. ${ }^{84}$ All other reviewers were full of praise. Joop van den Broek praised Van 't Veer for pointing out the "unbelievable shortcomings" of nineteenth-century colonial warfare. ${ }^{85}$ Tom Crijnen thanked Van 't Veer for proving that the Aceh War had been "the bloodiest and most revolting that the Netherlands had ever actively participated in," unremembering 1945 to $1949 .{ }^{86}$ A reviewer at the Leeuwarder Courant described De Atjeh-oorlog as a "clever book," ${ }^{87}$ while Het Vrije Volk added that "it will stimulate new discussions of war." 88

The blindness of the book reviewers mirrors the blindness of the film critics reviewing Pontecorvo's The Battle of Algiers. Film reviewers had failed to see the link between French atrocities in Algeria and Dutch atrocities in the Dutch East Indies. Book reviewers had refused to make the link between

83 Bijl, Emerging Memory, 197.

84 J.M., “De Atjeh-oorlog en de 'gecompliceerde' van Heutsz: Het pseudo-anti-colonialisme van Paul van 't Veer," De Waarheid, 13 December 1969.

85 Joop van den Broek, “Toen kolonialisme nog niet per se verwerpelijk was," Algemeen Handelsblad, 10 November 1969.

86 Tom Crijnen, “Atjeh: Nederlands smerigste oorlog," De Tijd, 1 November 1969.

87 "Boeken: Nederlands langste oorlog - Atjeh," Leeuwarder Courant, 24 November 1969.

88 Dick Schaap, “Atjeh: 40 jaren 'paciferen' - 100,00o doden," Het Vrije Volk, 31 October 1969. 
Dutch atrocities in the Aceh War and the War of Independence. Both were exercises in unremembering. In the compartmentalized world of Dutch book reviewers, the Aceh War (which ended in 1942) and the War of Independence (which started in 1945) were unrelated. Both had provoked accusations of war crimes and engendered parliamentary debates. Both involved routine the killing of civilians, torture of suspects, killing of prisoners, burning of villages and massacring of inhabitants. Yet it was as if the Hueting interview had never taken place. Paul van 't Veer's De Atjeh-oorlog had been published in a vacuum.

We have seen how the Dutch cabinet commissioned historian Cees Fasseur to oversee the writing of the Excessennota in 1969. Although academic historians remained shy of the subject, a further consequence of the Achter het Nieuws broadcasts was the announcement by the government that they would finance the publication of a collection of official documents relating to the decolonization conflict. However, Elsbeth Locher-Scholten argues that the cabinet had already reached this decision the previous year, so Hueting's interview simply accelerated the announcement. ${ }^{89}$ She argues that the ministers agreed to a primary source publication because it had three advantages. Firstly, it was in keeping with the nineteenth-century positivist tradition that the publication of official documents formed the basis for historical research. Secondly, it meant that historians could research decolonization by means of printed sources while being denied access to embargoed archives. Thirdly, this type of publication was the most neutral. ${ }^{90}$ In an area as sensitive as decolonization, a publication of primary documents would ruffle few feathers. Locher-Scholten considered this decision to be an indicator of the repressed trauma that dominated Dutch unremembering..$^{91}$

This decision of politicians provoked no resistance from historians, who, with few exceptions, acquiesced in an act of collective unremembering. Likewise, most of the press considered the publication of documents as sufficient. Consistent with the reviewers of Van 't Veer's De Atjeh-oorlog, the press collaborated in the process of unremembering. As the volumes of Officiële Bescheiden betreffende de Nederlands-Indonesische Betrekkingen 1945-1950 began to appear (a total of 20 volumes by 1996), Locher-Scholten maintains that the press showed a lukewarm interest, leaving some unreviewed..$^{92}$ She contrasts this with the reception given to Loe de Jong's 
official history of the Netherlands during World War Two. While the state commissioned a major narrative history of the nation during World War Two immediately after the war, when it came to decolonization, 20 years after the war, it commissioned the publication of official documents! The former had a printing of 100,000 copies per volume; the latter had a print run of 1,400 copies per volume. ${ }^{33}$ The former achieved bestseller status and ensured the author became a household name. The latter was incomprehensible to the layperson and increasingly ignored by the press. Jan Bank, commenting in 1995, argued that there was consensus around World War Two, but not when it came to decolonization. Consequently, the government had decided to limit publication to documentary sources for "scholars and semi-scholars" but not for the broad public. ${ }^{94}$

A multivolume publication on the development of Indonesian nationalism that appeared between 1975 and 1982 might have seemed promising. 95 However, this too was limited to the publication of written sources. Only documents from the former Department of the Colonies were used. These were reviewed and published with the special permission of the Minister of Internal Affairs. ${ }^{96}$ In other words, this collection on Indonesian nationalism was composed of Dutch official documents, not Indonesian nationalist documents. In effect, this Eurocentric approach created a representation of the growth of Indonesian nationalism seen exclusively though official, Dutch colonial eyes. Locher-Scholten calculated that of the 571 documents published, only 15 were from Indonesian nationalist leaders! 97

The Hueting interview lead to the publication of one scholarly work that, in turn, provided an impetus for the further academic study of decolonization in Indonesia. It was written, not by a historian, but by two sociologists, ex-conscripts who had fought in Indonesia and had become close friends. In Ontsporing van geweld (Derailment of violence), J.A.A. van Doorn and W.J. Hendrix tried to explain the excessive violence used by Dutch forces during the period from 1946 to 1949. Both authors had spent three and a half years at war in Indonesia. They brought back to the Netherlands "a pile of about 80 moderately to very accurately registered incidents that people would later term 'military excesses." ${ }^{\prime 8}$ They then set about further research, eventually building a collection of about $15^{\circ}$ pages. They called

94 Interviewed in Meijer, Oostindisch, 88.

95 Kwantes, De ontwikkeling.

96 Kwantes, introduction to De ontwikkeling, xi.

97 Locher-Scholten, “De ontwikkeling," 51.

98 Van Doorn and Hendrix, Ontsporing, 11. 
it "Research War Crimes Indonesia" (12). Somehow, as the memory of the conflict became latent or unremembered, they had put it to one side, both getting on with their careers. When Hueting appeared on television, Van Doorn and Hendrix realized, "it is now or never" (13).

The authors emphasized that their purpose was not to condemn or blame, but to provide an explanation for "a social history of military violence" (13). All case studies were anonymized. They began their study with an account of the rise of Indonesian nationalism in the early twentieth century and its development from a moderate Islamic form that appealed to the small middle class, through "proletarization" inspired by the Russian revolution. They described the repression after a failed communist uprising during 1926-1927, until the eventual emergence of Sukarno and his group, the Partai Nasional Indonesia (Indonesian National Party). For the first time the Dutch faced a genuine popular movement. This led, in the 1930s, to a new system of repression led by the Dutch political police (21-32). Together with the hardship caused by the world economic crisis of the 1930s, this contributed to a hardening of attitudes among conservative Dutch and Indisch colonials.

The authors accepted the view of the Bersiap as a period of mass plundering and massacres (51). However, it was also "a revolutionary process whereby a social revolution was conducted by armed violence and a collective national consciousness was manifested" (51-52). They gave examples from the Indisch press, describing nationalist atrocities in detail (62). This contributed to what they called the "ideologization" of the colonial society, in which the colonial population became convinced of three beliefs: that the Indonesian republic had been manufactured by Japan (86-88); that there was no such thing as Indonesia (88-91); and that the native population was terrorized and in need of rescuing (91-95). They also gave attention to the difficult position of the Indo: "The tragedy in the position of the Indo-European is that he could indeed work his way up within the shadow of the colonial system, but at the same time had to fight tendencies within this system - racial discrimination from 'totoks" (64). The authors described the changing roles of the "colonial troika," consisting of civil servants, business people and the military (69-73). As the Indisch community began to play an ever-stronger role in the colony, they found themselves to be opposed to the growing Indonesian nationalism, but also at loggerheads with the Dutch government, who wanted to see an increased share of native participation in governing the colony. This was opposed by the Indisch community, who fell under the influence of the propaganda spread by the Dutch Nazi Party (73-75). This contributed to an increased militarization of colonial society and eventually 
led to the recruitment of irregular troops, some of whom were drawn from the criminal world of Batavia in 1948 (107-109).

The authors attempted to examine the attitudes of tens of thousands of recruits sent from the Netherlands, the young generation who had experienced violence and repression under the Nazi occupation and who looked with admiration to their Allied liberators. Those who had volunteered for service in Indonesia often had a background in the anti-Nazi resistance, or had become "onderduikers" (a person in hiding), or had been forced labourers in Germany (120-131). Violence had become a way of life for them, albeit, violence in the service of a good cause.

The authors devoted special attention to the Royal Netherlands East Indies Army (KNIL), which played a key role in the war, often providing leadership and training (139-147). They quote the words of a KNIL sergeant, who tells conscripts that natives cannot rule themselves, that only whites can rule Asia, for which "an iron fist is needed, because natives simply prefer to be kicked rather than led with a soft hand" (145-146). They analyse the guerrilla tactics used by the Indonesians and the difficulties that the Dutch had in responding to such irregular warfare (148-182).

The authors also confronted the topic of Westerling and his pacification of South Celebes, claiming that Westerling used rough violence with the blessings of his superiors, General Spoor, Van Mook and the Intelligence Service (81). They suggested that the mobilization of Westerling's special troops by the high command was an example of "reactive organizational violence" (194-195). This implied that the notorious violence associated with the name Westerling was a product of structural violence.

This provided the frame in which they evaluated the prevalence of the use of excessive violence by the Dutch in Indonesia. They presented a number of cases. They referred a number of times to Hueting's interview and suggested: "It is much more important to accurately know how frequently such excesses happened," adding that the Excessennota "gives a wholly incomplete image," calling it "the tip of the iceberg" (224-225). However, their main contribution was to defend a thesis regarding the structural aspect of the use of excessive violence: Excessive violence occurs when an accepted authority sees its legitimacy disappear and with its legitimacy gone, the authority needs to call upon power. Power then reaches for the instrument of violence. At that moment, the preeminent apparatus of violence, the army, gets the main role (202). Without any countervailing power from other social institutions, the army, whose main specialty is the use of violence, destroys social pluralism, and consequently overrides institutions such as the judiciary and the police (202-203). For the Dutch, the role of policing fell to the members of the 
intelligence services, who were responsible for many excesses. The only possible limitation of this would have been the army commanders, who were reluctant to interfere (204).

The book was published in May 1970. It received a number of positive reviews in the left-wing and right-wing press. The fact that no individuals were named, the term "war crimes" had not been used and the responsibility for excessive violence was laid at the feet of a system, not individuals, made it appear inoffensive. However, in the short term, the book was quite ignored, much like the Excessennota. In an afterword, written for a later edition, Dirk Vlasboom writes: "Ontsporing van geweld missed the tide in 1970. The wave of emotions sparked by the Hueting affair had faded." ${ }^{\prime 9}$

\section{Televisual Impact}

The Hueting interview stimulated a number of programmes from different television broadcasters during the following years. The television broadcaster VARA followed up the publication of Van Doorn and Hendrix's book with a short programme, Ontsporing van Geweld, in May 1970. Three years later the Dutch Christian Radio Association (NCRV) broadcast En Wij, wij leven voort in een doolhof (And we, we live on in a maze), in which a veteran discussed the nightmares and intense guilt he suffered from, having shot dead no less than ten Indonesian prisoners during the conflict. Journalist Nico Scheepmaker described the programme as "something special." ${ }^{100}$ The many reactions led to the producer broadcasting a second programme a month later.

However, the situation around televised remembering remained ambiguous. In the wake of the Hueting interview, journalist Joop Buddinghausen and cameraman Hans van der Busken persuaded former Captain Westerling to give his first ever television interview about his extrajudical executions on South Celebes in 1946. To their disappointment, they discovered that no broadcaster would run the risk of transmitting the interview. Over 40 years later, the existence of the interview became known. ${ }^{101}$ It was broadcast in

99 Dirk Vlasboom, foreword to Van Doorn and Hendrix, Ontsporing, 337.

100 Nico Scheepmaker, “En wij. Wij leven voort in een doolhof," Leeuwarder Courant, 11 November 1973.

101 Lidy Nicolasen, "Kaptein Westerling geeft in tv-interview wandaden op Zuid-Celebes toe," De Volkskrant, 14 August 2012; Niels Posthumus, "Westerling erkende executies op Zuid-Sulawesi in opgedoken interview uit 1969," NRC Handelsblad, 14 August 2012. 
2012, updated by Van der Busken, with commentary from historian Willem IJzereef and lawyer Liesbeth Zegveld. ${ }^{102}$

In 1976, the public television broadcaster VPRO, filling the gap left by historians, treated their prime-time viewers to a full evening of the history of decolonization. ${ }^{103}$ Indonesia Merdeka was a piece of remarkable television history, not least because of its length, over three hours without a break. Filmed in colour, it was the first Dutch documentary to tell the story of the final days of the colony, including an Indonesian point of view, with commentary from some Dutch participants. Most interviewees were Indonesian nationalist leaders, including Vice President Muhammad Hatta. The writer and director of the programme, Roelof Kiers, travelled to Indonesia to meet the former rebels in their own homes. In limiting the number of interviewees to seven, spread over three hours, Kiers aimed for depth. All interviewees spoke in fluent Dutch. Dutch, Japanese and Indonesian propaganda films were interwoven throughout. Kiers supplied an occasional narration, but mainly the interviewees told the story. A week before the broadcast Kiers warned: "There is a lot of talk. There is no visible drama," adding that the programme is not "a historical reconstruction." Instead, it presents people "letting their memories play." He concluded that it "is more of a supplement to the official history."104 One is tempted to ask, what official history?

Peter Schumacher wrote that nothing like this had ever been presented before, claiming that this unique film would itself be regarded as a historical document and would be rebroadcast years hence. He recommended to viewers with a connection to Indonesia "and that is many hundreds of thousands in the Netherlands," that the film is not to be missed. ${ }^{105}$ The programme -3 hours and 16 minutes of non-dramatic, serious television - attracted one and a half million viewers. Due to public demand, it was repeated six months later. ${ }^{106} \mathrm{~A}$ brochure with the complete narrative and interviews was also distributed. ${ }^{107}$ Schumacher's prediction, that the documentary would be rebroadcast years hence, was proven accurate. It was reshown in 1989, with

102 Altijd Wat, NCRV, 14 August 2012.

103 Indonesia Merdeka, VPRO, 1 December 1976.

104 Jan Eijkelboom, "Indonesië merdeka, weer gewaagd idee van VPRO," Het Vrije Volk, 25 November 1976.

105 Peter Schumacher, “TV vanavond: zeer unieke 'Indonesia Merdeka," NRC Handelsblad, 1 December 1976.

106 "VPRO herhaalt avondlang Indonesische historie," De Telegraaf, 8 August 1977.

107 "Indonesia Merdeka," Nieuwsblad van het Noorden, 10 August 1977. 
introductions from historians Jan Bank and H.W. von der Dunk. It was referred to as an almost infallible historical document. ${ }^{108}$

Indonesia Merdeka attempted to put paid to the myth that Sukarno and Hatta were collaborators of the Japanese. Similarly, it showed that Indonesian nationalism was not a direct product of Japanese propaganda. Kiers asked Indonesian army commander Nasution about the fact that Dutch soldiers had resorted to terror. Nasution answered that that was understandable, given the horrible conditions in which they were fighting. He added that he and his nationalist comrades had hoped that the Dutch would resort to terror, knowing that this was a sign of weakness that would further undermine the Dutch cause. There is no further talk of excesses or war crimes. Kiers asked a Dutch former plantation owner: "Do you have any idea why the Netherlands lost the East Indies?" The totok and his wife look deeply saddened, and he answered, "Because the government did not have foresight." He added that he, too, had lacked foresight, and that is why thousands of "Dutch lads" remain buried in the former colony. Dutch politicians, experts and colonials had completely misread the strength of the newly imagined community that was Indonesia. Undoubtedly, Kiers agreed with one of his interviewees, a former political advisor to Van Mook, who suggested the Dutch empire had collapsed because Indonesians had no reason to support it.

\section{Bibliography}

Assmann, Aleida and Linda Shortt. "Memory and Political Change: Introduction." In Memory and Political Change, edited by Aleida Assmann and Linda Shortt, 1-14. Basingstoke: Palgrave Macmillan, 2012.

Bank, Jan. "Televisie in de jaren zestig." Bijdragen en Mededelingen betreffend de Geschiedenis der Nederlanden 101, no. 1 (1986): 52-75.

Bijl, Paul. Emerging Memory: Photographs of Colonial Atrocity in Dutch Colonial Remembrance. Amsterdam: Amsterdam University Press, 2015.

Born, Karin van den, Gerda Jansen Hendriks, Yfke Nijland and Ad van Liempt, "De Excessennota." In: Andere Tijden: Nieuwe inzichten in oude kwesties, edited by Ad van Liempt, 162-176. Amsterdam/Antwerpen: L.J. Veen, 2002.

Bourke, Johanna. “Introduction: 'Remembering' War." Journal of Contemporary History 39, no. 4 (2004): 473-485.

108 Peter Schumacher, "Indonesia Merdeka is een historisch en bijna onaantastbaar tv-document," NRC Handelsblad, 12 August 1989. 
Connerton, Paul. How Societies Remember. Cambridge: Cambridge University Press, 1996.

Daelen, Verle Vanden. "Loe De Jong en Maurice De Wilde: Twee oorlogsmonumenten." Bijdragen tot de Eigentijdse Geschiedenis 22 (2010): 161-196.

Bank, Jan, ed. De Excessennota: Nota Betreffende het archiefonderzoek naar de gegevens omtrent excessen in Indonesië begaan door Nederlandse militairen in de periode 1945-1950. The Hague: Sdu, 1995 [1969].

Doorn, Jacques A.A. van and Wim J. Hendrix. Ontsporing van geweld: over het Nederlands/Indisch/Indonesisch conflict. $4^{\text {th }}$ ed. Zutphen: Walburg Pers, 2012 [1 ${ }^{\text {st }}$ ed., Rotterdam: Universitaire Pers Rotterdam, 1970].

Erll, Astrid. Memory in Culture. Basingstoke: Palgrave Macmillan, 2011.

Galen, John Jansen van. Afscheid van de Koloniën: Het Nederlandse Dekolonisatiebeleid 1942-2012. Amsterdam and Antwerp: Atlas Contact, 2013.

Ginkel, Rob van. "4 en 5 mei." In Een open zenuw: Hoe wij ons de tweede wereldoorlog herinneren, edited by Madelon de Keizer and Marije Plomp, 27-38. Amsterdam: Bert Bakker, 2010.

Gouda, Frances. "Divided Memories of World War II in the Netherlands and the Dutch East Indies: Sukarno and Anne Frank as Icons of Dutch Historical Imagination." In Confronting Memories of World War II: European and Asian Legacies, edited by Daniel Chirot, Gi-Wook Shin and Daniel Sneider, 105-134. Seattle and London: University of Washington Press, 2014.

Graeff, M.J. de, ed. Nederlandsch Indie 1945: Indonesië 1949: Achter het Nieuws 1969: drie VARA producties. Hilversum: VARA, 1969.

Halbwachs, Maurice. On Collective Memory. Edited and translated by Lewis A. Coser. Chicago and London: University of Chicago Press, 1992 [1950].

Kousbroek, Rudy. Het Oostindisch Kampsyndroom. Amsterdam: Olympus, 2005.

Kwantes, R.C., ed. De ontwikkeling van de nationalistische beweging in NederlandschIndië:Development of the Nationalist Movement in the Netherlands-Indies, 4 vols. Groningen: Wolters-Noordhoff, 1975-1982.

Lijphart, Arend. The Trauma of Decolonization: The Dutch and West New Guinea. New Haven and London: Yale University Press, 1966.

Locher-Scholten, Elsbeth. "De ontwikkeling van de nationalistische beweging in Nederlands-Indië.” Bijdragen en Mededelingen betreffende de Geschiedenis der Nederland 99, no. 1 (1984): 45-54.

Locher-Scholten, Elsbeth. "Een bronnenpublicatie als signaal van koloniale trauma? Ontstaan en ontvangst van de Officiële bescheiden." Bijdragen en Mededelingen betreffende de Geschiedenis der Nederlanden 111, no. 4 (1996): 473-492.

Maar, Rimko van de. Welterusten meneer de president: Nederland en de Vietnam Oorlog, Amsterdam: Boom, 2007. 
Meijer, Remco. Oostindisch doof: Het Nederlandse debat over de decolonisatie van Indonesië. Amsterdam: Bert Bakker, 1995.

McLuhan, Marshall. The Medium is the Massage. London: Penguin, 2008 [1967].

McLuhan, Marshall. Understanding Media: The Extensions of Man. London and New York: Routledge, 1964.

Nieuwenhuys, Rob. Oost-Indische spiegel. Wat Nederlandse schrijvers en dichters over Indonesië hebben geschreven vanaf de eerste jaren der Compagnie tot op heden. Amsterdam: Querido, 1972.

Raben, Remco. "Dutch memories of captivity in the Pacific War." In Forgotten Captives in Japanese-Occupied Asia, edited by Karl Hack and Kevin Blackburn, 94-110. London and New York: Routledge, 2008.

Raben, Remco. "Koloniale Vergangenheit und postkoloniale Moral in den Niederlanden." In Verbrechen erinnern: Die Auseinandersetzung mit Holocaust und Völkermord, edited by Volkhard Knigge and Norbert Frei, 9o-110. Bonn: C.H. Beck, 2002.

Raben, Remco. "A New Dutch Imperial History? Perambulations in a Prospective Field." BMGN - Low Countries Historical Review 128, no. 1 (2013): 5-30.

Ricoeur, Paul. Memory, History, Forgetting. Translated by Kathleen Blamey and David Pellaur. Chicago and London: University of Chicago Press, 2004.

Schilt, Jan. Soldaatje spelen onder de smaragden gordel. Amsterdam: Van Gennep, 1969 .

Smits, Boudewijn. Loe de Jong, 1914-2005: Historicus met een missie. Amsterdam: Boom, 2014.

Tollebeek, Jo. "De zuigkracht van het medium. Historici als televisie deskundigen." Bijdragen en Mededelingen betreffend de Geschiedenis der Nederlanden 116, no. 4 (2001): 465-482.

Trouillot, Michel-Rolph. Silencing the Past: Power and the Production of History. Boston: Beacon Press, 1995.

Varenne, Jan. Eer de haan kraait... Een serdadoe soesoe tussen de peloppers op Java. Amsterdam: Paris, 1969.

Veer, Paul van 't. De Atjeh-oorlog. Amsterdam: De Arbeiders Pers, 1969.

Vree, Frank van. "Bilder/Gegenbilder. Kolonialgeschichte und visuale Erinnerungskultuur 1945-1995." In Kolonialismus und Erinnerungskultuur: De Kolonialvergangenheit im kollektiven Gedächtnis der deutsche und niederlandischen Einwanderungsgesellschaft, edited by Helma Lutz and Kathrin Gawarecki, 181-202. Munster: Waxmann Verlag, 2005.

Vree, Frank van. "De Overval." In Een Open Zenuw: Hoe wij ons de tweede wereloorlog herinneren, edited by Madelon de Keizer and Marije Plomp, 445-454. Amsterdam: Bert Bakker, 2010. 
Wesseling, Henk L. "Post-Imperial Holland." Journal of Contemporary History 15, no. 1 (1980): 125-142.

Zwaan, Jacob. Soldaat in Indië: de geschiedenis van een peloton. Zwolle: J.J. Tijl, 1969.

\section{Television}

Achter het Nieuws. VARA, 1969. [A series of three broadcasts.]

Altijd Wat. NCRV, 2012.

De Bezetting. [1960-1965]. Directed and presented by Loe de Jong. Amsterdam:

NIOD Institute for War, Holocaust and Genocide Studies/NTR, 2014. [Complete original edition of 21 episodes in boxed edition of seven DVDs.]

Indonesia Merdeka. VPRO, 1976

De Tijd Staat Even Stil: De politionele acties, NCRV. 1993 


\title{
5 Postmemory
}

\begin{abstract}
The second generation of those repatriated from the former colony during decolonization inherited a memory of traumatic loss that they themselves had not experienced. The violent actions of Moluccan youths during the 1970s were not anti-colonial attempts to promote liberation but can be best understood as attempts at contesting Dutch colonial unremembering. During the 1980s, postmemory authors, like Jill Stolk, Marion Bloem and Adriaan van Dis, problematized unremembering, drawing attention to their postcolonial condition and complicating the narrative of us (the Dutch) versus them (the Indonesians). Radio and television during the 1980 increasingly offered platforms where the brutality of the war of decolonization and perpetration of widespread Dutch atrocities were highlighted. The testimony of veterans, not historians, dominated these narratives.
\end{abstract}

Keywords: decolonization, unremembering, Moluccans, Marion Bloem, postmemory, postcolonialism

Collective loss has a long, complicated and often violent afterlife. Eva Hoffman has written: "Sometimes, if the loss is large enough, the trail seeps and winds like invisible psychic ink through lives, decades and generations." It is the fate of the second generation that they "live with a multitude of lost 'objects' that they never had a chance to know." For the second generation, melancholy becomes the dominant form of remembering. ${ }^{2}$

The second generation inherits a memory of traumatic loss that is not based on first-hand experience. Children of those who experienced loss first-hand know of it intimately, from the stories and the silences that they have experienced at home, among the elders whom they know and

$1 \quad$ Hoffman, “The Long," 406.

2 Ibid., 411.

Doolan, P.M.M., Collective Memory and the Dutch East Indies. Unremembering Decolonization. Amsterdam: Amsterdam University Press 2021 DOI: 10.5117/9789463728744_CHO5 
love. Marianne Hirsch developed the term "postmemory" to describe this relationship that the second generation bears

to the personal, collective, and cultural trauma of those who came before - to experiences they "remember" only by means of stories, images and behaviours among which they grew up. But these experiences were transmitted to them so deeply and effectively to seem to constitute memories in their own right. ${ }^{3}$

Postmemory describes a condition of second-generation diasporic populations who have survived a collective trauma. Children of exiled survivors have not experienced directly the initial trauma, but tend to participate in the "guardianship" of that traumatic past, even as that past slips into history. ${ }^{4}$

In her study of Holocaust postmemory, Hirsch examined "the long-term effects of living in close proximity to the pain, depression, and dissociation of persons who had witnessed and survived massive historical trauma." In this chapter, we will see that, like the second generation of Holocaust survivors, second-generation Moluccan repatriates and second-generation Indisch repatriates created postmemory representations of decolonization. The Moluccan representations came in the form of political violence. In the Indisch case, in the form of literature.

\section{The Moluccan Attacks}

To the consternation of Dutch authorities and public, the country was confronted in the 1970s with a home-grown terrorist movement whose actions, even now, form an aspect of Dutch collective memory. ${ }^{6}$ The hundreds of islands that make up the Moluccas are the original, fabled "Spice Islands." From the late nineteenth century onward the Dutch colonial government practised large-scale recruitment among the Christian section of the Moluccan population for their colonial army, the Royal Netherlands East Indies Army (KNIL). Moluccans gained a reputation for being good 
soldiers with "unquestioning, if not fanatical loyalty to the Dutch, especially to the House of Orange."

The transfer of sovereignty from the Netherlands to the new republic left some Moluccans in an awkward position. Months after independence, and before the full demobilization of the Dutch colonial army had taken place, the government in Java decided to end federalism and rule directly from Jakarta. Some Moluccans responded by declaring an independent Republik Maluku Seletan (RMS, Republic of South Moluccas) and the new Indonesian government moved to crush the rebellion. Although the KNIL was disbanded in July 1950, 9,000 soldiers on Java had yet to be demobilized, including 4,000 Moluccans. These Moluccans feared that they would become victims of reprisals if they were to be demobilized on Java. In December 1950, a court in The Hague ruled it would be illegal for Dutch authorities to demobilize Moluccans against their will on Indonesian soil. ${ }^{8}$ In February 1951, the Dutch government lost their appeal against this decision and consequently the Moluccan KNIL soldiers were offered a choice: demobilization on Java or embarkation for a temporary sojourn in the Netherlands, together with their families. ${ }^{9}$ They chose the latter. This was considered, by all concerned, a temporary solution. It was hoped the Moluccans could return to their homeland once stability had been restored.

Upon arrival in Holland, much to their surprise and anger, the soldiers were immediately discharged unceremoniously. ${ }^{10}$ In effect they were now unemployed and stateless. The search for temporary housing for the 12,500 Moluccans was a problem for a Dutch government dealing with a serious housing shortage in the immediate post-World War Two period. ${ }^{11}$ Eventually they were housed in 91 locations, in former camps for the unemployed, as well as former monasteries, former military barracks and even former concentration camps. ${ }^{12}$

The Moluccans felt a deep and bitter sense of betrayal. Motivated by an attempt to maintain Dutch influence in the archipelago, the only Dutch who seemed to sympathize with their plight were right-wing, die-hard imperialists - people like Gerretson and Gerbrandy, and the conservative journalist Jan Fabius, who compared their treatment by the Dutch with

8 Smeets, "De plaats," 7; Steijlen, $R M S$, 51-52.

9 Smeets, "De plaats," 13.

10 Bootsma, De Molukse Acties, 19.

11 Ibid., 18.

Akihary, "Van Almere," 40-47. 
the treatment of the Jews by the Germans. ${ }^{13}$ Gerbrandy was their most prominent supporter. In $195^{\circ}$ he co-founded the pro-colonial organization Door de Eeuwen Trouw (Loyal through the Centuries) in order to push for their right of self-determination. ${ }^{14}$

The ideology of the RMS continued to live on, dominating the collective life among this insular community. Akihary argues that it suited the Dutch government for the Moluccans to live in relative isolation - "tropical enclaves in the Dutch landscape," preventing assimilation..$^{15}$ But historian Fridus Steijlen demonstrates that this housing policy of the authorities came back to bite them, for it played a crucial role in the development of Moluccan antiDutch resentment. ${ }^{16}$ Over the years, supporters of the RMS ideal were given the opportunity to provide leadership and instil ideological unity within the community, with little toleration for alternative viewpoints. ${ }^{17}$ According to Henk Smeets, Moluccan support for the Dutch state and crown had always been relative, and the slogan "Ambon - loyal through the centuries" was in origin a piece of pro-Dutch propaganda.$^{18} \mathrm{But}$, in exile and under the influence of the RMS ideal, this narrative of the faithful Moluccans who had demonstrated loyalty to the Dutch state for over three centuries now took on mythical proportions. ${ }^{19}$ Intimidation and social ostracism were used by the Moluccan leadership to conserve their position and promote the RMS ideal. ${ }^{20}$ Consequently, though the Dutch government never gave any indication of supporting the RMS ideology, their housing policy during the 1950s paradoxically facilitated "the development of an RMS movement in the Netherlands. ${ }^{21}$

By the late 1960 s and early 1970s, a second generation, raised in isolation from Dutch society, had become disillusioned at watching the older generation suffer. About 80 per cent of Moluccans in the Netherlands remained stateless. ${ }^{22}$ According to Bartels some young Moluccans "felt it was their responsibility to restore their parent's honour, if not to avenge them."23 In 1966, in response to the execution of Moluccan separatist leader RMS

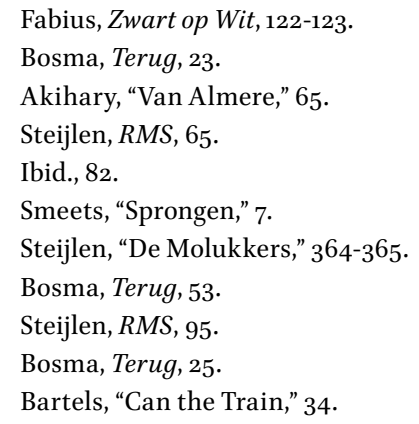


President Chris Soumokil by the Indonesian regime, Moluccan youths stormed and set fire to the Indonesian embassy in The Hague. Another attack on the Indonesian ambassador's residence in Wassenaar in 1970 resulted in the killing of a Dutch policeman. ${ }^{24}$ In 1975, Moluccans hijacked a train in the north of the country, while others occupied the Indonesian consulate in Amsterdam, resulting in four fatalities among the hostages. In 1977, two groups hijacked a train and occupied a primary school, taking hundreds of children and adults hostage. The stand-off lasted nearly three weeks, gained world media attention and ended with Dutch military intervention and the killing of six Moluccans and two hostages. A final action in 1978, in the town of Assen, resulted in another hostage stand-off and a further two killings.

These violent actions were about collective memory and unremembering. The 1970 action in Wassenaar, according to Steijlen, provided "a reminder of the political ideals of the Moluccans in the Netherlands." 25 For years the older-generation Moluccans had tried to engage Dutch interest in their plight but this had proved futile. The young generation were rebelling against the failed methods of their elders, but were also trying to forcefully remind the Dutch of the last days of decolonization. These were not simply terrorist actions, but representations of decolonization, marking a failure on the part of the Dutch historical profession. No major historian had shown an inclination to investigate the Moluccan past or to educate the Dutch public regarding the roots of Moluccan discontent. Yet, South Moluccan nationalism was not simply a product of a failed integration policy, but a product of a bad decolonization policy. ${ }^{26}$ These violent actions represented the historical wounds festering among one specific group impacted by decolonization.

Dipesh Chakrabarty uses the concept of "historical wounds" to help understand the perspective of groups who have felt themselves to be victims of collective injustice. He traced the phenomenon to the immediate period of decolonization, the 1950s and 196os. However, it was only in the $1990 \mathrm{~s}$ that groups who were perceived as "givers of the wound in the first place" began to acknowledge their role. ${ }^{27}$ During the 1970 s the Dutch public were oblivious to the suggestion that they had ever inflicted a historical wound. Thus, the Dutch public watched these actions on their television screens, "dumbfounded." ${ }^{28}$ The Moluccan actions were symptoms of unremembering.

24 Ibid.

25 Steijlen, $R M S$, 133.

26 Schmid et al., Zuidmolukse terrorisme, 21.

27 Chakrabarty, "History," 78.

28 Wesseling, "Post-Imperial Holland," 137. 
It is tempting to see the era of Moluccan terrorism, 1970-1978, against the background of the progressive, liberation movements of the 1960s that turned violent in the 1970s. Emerging from the 196os youth movement, rebellion came in the form of the Blank Panthers in the USA, the Red Army Faction in West Germany, the Red Brigades in Italy and the Japanese Red Army in Japan. These leftist groups and their supporters were led by youth who believed they were attacking the world of their elders in order to bring about radical change. Sometimes their aims seemed to merge with the national liberation objectives of the Irish Republican Army, the Basque ETA and the Palestinian Liberation Organization. One of the train hostage takers at Wijster in 1975 linked his struggle with that of the Palestinians as well as the work of African-American political activist Angela Davis, arguing that nearly all Moluccan youths had a poster of Che Guevara and saw Che and Moluccan guerrilla leader Chris Soumokil as equals. ${ }^{29}$

This perspective is inaccurate on three counts. Firstly, Moluccan activism was not a national liberation movement attempting to gain freedom from their colonial masters. On the contrary, Moluccans were former allies of the colonial masters at war against the Indonesian national liberation movement. The struggle for the RMS, in the eyes of the Moluccan fathers, had been an extension of the Dutch "police actions," but the sons, ironically, fought in the name of anti-imperialism. This was a postcolonial dilemma. Secondly, Moluccan activists in the Netherlands were not bent on radical social or economic change within the society that they were attacking, unlike the Red Army Faction or the Red Brigades. They had no social programme at all for the Netherlands. The main objective was to undo Dutch unremembering, in order to help the Moluccans to return to their South Moluccan republic. Thirdly, young Moluccan activists were not rebelling against their elders. On the contrary, they were rebelling on behalf of their elders. Theirs was a postmemory activism rooted in the colonial experience of their parents.

Ever since the arrival of the Moluccans in the Netherlands, many Dutch recognized their loyalty to Dutch colonialism, especially the conservatives in the Comité Actie Minderheden (Minorities Action Committee) and Door de Eeuwen Trouw (Loyal through the Centuries). ${ }^{30}$ The Moluccan position within the KNIL had given Christian Moluccans a privileged position within colonial society, one in which they considered themselves to be above other native peoples, gaining themselves the nickname "Black Dutch" but also "Dog 
of the NICA [Netherlands Indies Civil Administration]. ${ }^{31}$ Steijlen argues that this position translated into an identification with the Western colonial elite and lies at the root of Moluccan nationalism. ${ }^{32}$ At the beginning of the 1960 s, Moluccan future president in exile, J.A. Manusama, was trying to convince the world that their struggle formed a vital link in the global war against communism. ${ }^{33}$ Using colonialist arguments, he justified the Dutch bloodstained penetrations into the Indonesian archipelago, by claiming this was no worse than what the locals did. ${ }^{34}$

However, the young activists of the 1970s profiled their struggle as anti-imperialist. Tete Siahaya was one of the activists who attacked the Indonesian ambassador's residence in Wassenaar in 1970. Incredibly, a Dutch radio journalist discovered the telephone line to the residence was still open and got Siahaya on the line. The interview that ensued was broadcast live to the Dutch public. Siahaya's opening words, describing their motivation, were, "Hello Sir. The whole action was set up because of the following: we young people, we won't take it anymore, that for 20 years ours parents have been insulted." 35

Former Wijster train hijacker Abe Sahetapy claimed in his prison diary that their actions were part of a political struggle against the Dutch "barbaric regime" and its "henchman," Indonesia. ${ }^{36}$ Sahetapy maintained an antiimperialist attitude throughout, calling police or prison guards wolves, werewolves and pigs, brutes, dogs, and skunks. ${ }^{37}$ Dutch authorities are referred to as "fascist." ${ }^{8}$ The Moluccan leadership are "Judases" (67). He even expresses his anger at the Moluccan people because they didn't offer 100 per cent support to the violent actions (67).

Sahetapy claimed that the Moluccan struggle was in line with other anti-imperialist struggles (12-13). Yet, the Moluccans had been supported by the most right-wing elements in The Hague. Furthermore, Moluccans in the Netherlands, including the second generation, owed their status as a separate people to their cooperation with the colonial power. Their existence as a political identity was rooted in the hierarchy of colonialism,

These words were rebroadcast on television in De tijd staat stil: De Zuidmolukse droom, NCRV, 7 June 1994.

36 Sahetapy, Tawanan, 79 .

37 Ibid., 6, 23, 26, 33 .

38 Ibid., 10, 61, 79, 80 . 
but was now propagated in the vocabulary of equalitarian anti-imperialism. Thus, the new generation had seized the baton of revolution from their elders and transferred it from a right-wing to a left-wing struggle. This double consciousness allowed them to be the privileged products of Dutch colonialism and the innocent victims of Dutch colonialism at the same time.

Identification with the Black Panthers was superficial. Rather, their motivation was the more intimate frustration of witnessing the pain of their parents, transmitted to them within the family through, to use Hirsch's phrase, "a shared archive of stories." 39 A sense of helplessness caused them to unleash violence upon the unremembering Dutch. They aimed to force remembering of the wound upon those who they considered to be the perpetrators. Near the beginning of his book, Sahetapy admits that what had given him the power to survive is the strength he gained through his "belief" (11). It was the God of his parents, rather than Che, that provided the inspiration.

Baukje Prins went to a primary school during the 1960 s where half the children were Dutch and half were Moluccan. Decades later, she wrote an oral history of that time, based on interviews with her former classmates and teachers. She noticed that former Moluccan classmates emphasized the closeness of their relationship with their parents far more than the Dutch interviewees. The Moluccans continually referred to the "immigration history" of their parents and the "shock of political exile."40 Prins concludes that her Moluccan former classmates felt duty bound to compensate their parents for their sacrifices, by giving them something back. ${ }^{41}$

It is significant that, while associating himself with the struggles of Palestinians, African-Americans and Cubans, Cornelius Thenu inserted this dedication in his book: "For my parents, with love always." He was raised in the former concentration camp Westerbork, surrounded with barbed wire, yet admitted that it was an idyllic youth, isolated from the Dutch world while playing in the woods. ${ }^{42}$ This ended when he became aware of the complaints of his elders: "The question when they could return home ran like a thread though the lives of my parents."43 As a boy, Thenu had listened to the stories of life in the army before the forced move to the Netherlands, but also to the stories of how his parents had been treated 
upon arrival in $195^{1}$ and had been "betrayed by the Dutch government." ${ }^{\prime 4}$ In a television documentary released at the time of his book's publication, Thenu described how his parents had experienced military discharge as if "a friend had stabbed you in the back." ${ }^{\text {45 }} \mathrm{He}$ emphasized that once you have seen your parents crying because of an injustice done to them, "that remains in your thoughts for a long time." 46

The difference between the older generation and that of the second, according to Thenu, was that his parents had remained loyal to the Dutch, seeing Indonesia as the "great evil."${ }^{\text {"77 }}$ But, the young generation was filled with hatred towards the Dutch for what they had done to their Moluccan parents. ${ }^{48}$ Consequently, their sole objective when they seized the train at Wijster in December 1975 was "to make our struggle for an independent South Moluccan republic known to the Netherlands and the rest of the world."${ }^{\text {"9 }}$

We find similar explanations in interviews with other Moluccans who, having served their time in prison, came to reflect upon their deeds. In a studio discussion broadcast on television in 1994, presenter Philip Feriks introduced the Moluccan guests as "a forgotten group of compatriots." ${ }^{\circ}$ Guests included four of those who had occupied the ambassador's residence in 1970. One activist made the point that the Dutch government had acted rudely towards his parents. Another, with tears in his eyes, declared that "when I hear [our] old people talking it pains my heart. You see, I'm a bit deaf, but you [the Dutch] are worse than I am. You never listen."

For a four-part documentary in 2000, Dutch Approach, a number of former activists agreed to be interviewed. Siahaya compared the discharge of his father from the army in $195^{1}$ to castration. ${ }^{5^{1}}$ In his study of the unused interview transcripts for this programme, Bootsma quotes Gustav Tehupuring, one of the activists who had held over a hundred children and their teachers hostage: "At Christmas our uncles and aunties would come to visit and that was really nice but also a bit sad. [...] I found it terrible to realize that my father had not stayed in his own country, but in a temporary shelter in the Netherlands. ${ }^{.52}$ Sahetapy was sentenced to fourteen years

Ibid., 25-27.

Interviewed in Antenne: Korban, EO, 1998.

Ibid.

Thenu, Korban, 40.

8 Ibid., 23.

Ibid., 49.

De Tijd Staat Even Stil: De Zuidmolukse droom, NCRV, 7 June 1994.

1 Dutch Approach: Gebroken belofte, NPS, 6 November 2000.

Bootsma, De Molukse Acties, 28. 
imprisonment for his part in executing three hostages in Wijster in 1975 . Bootsma quotes him: "When I looked at my parents or at other parents, I saw them suffering from this burden - the whole process with the KNIL, getting sacked from the KNIL, the experience of the camps, living in two rooms in the barracks."53

In an interview in 2010, Paul Polnaija, one of those who occupied the primary school in 1977, suggested that problems arose when "I saw the sadness and pain of my parents and I wanted to do something about it."54 Five years later he admitted: "I hated the Dutch" because of "what had happened to my parents." 55

Paul Saimima participated in the hostage taking on the train at Wijster in 1975. Although refusing to discuss feelings of guilt (he had been involved in the execution of two passengers), he broke his silence and gave an interview in 2010. He said that the older generation had engaged for 20 years in peaceful, reasonable protests, but "that brought about no result. It began to eat away at me. You must never hate people, but forget what had been done to my parents? Never." 56

Junus Ririmasse is one of two Moluccans who survived the military assault on the train in 1977. In an interview in 2015, he claimed that during the stand-off he often thought about his parents and how, against their will, they had been brought to the Netherlands. He did it for them, he added. ${ }^{57}$

While the ultimate goal was the achievement of an independent Republic of South Moluccas, the activists of the 1970s were motivated by the pain of their parents, pain rooted in the wound of decolonization. Although Moluccan youth lived in relative isolation, they attended Dutch schools and mixed with outsiders and undoubtedly must have imbued something from the youth culture of the 196os. The Black Power movement in the USA suggested a template for their own struggle, giving them an anti-imperialist vocabulary and allowing them to reinterpret history in a manner that concluded that their parents, far from being collaborators of the colonial elite, were victims of Dutch imperialism..$^{8}$ Their aim was to repair the historical wound their parents had suffered. Their method was to awaken

53 Ibid., 29.

54 Paul Prillevitz, "Interview met Molukse gijzelnemer," Historiën, 6 December 2010, http:// www.historien.nl/interview-met-molukse-gijzelnemer, accessed 10 June 2016.

55 De Verandering, NOS, 19 September 2015.

56 Jacob Hoekman, "Molukse kaper: Bij Wijster was het tijd om te doden," Reformatisch Dagblad, 7 May 2010.

57 Henk Wollreich, “Overleven is Geen geluk," Dagblad van het Noorden, 2 May 2015.

$5^{8}$ Steijlen, $R M S$, 144-145. 
the Dutch from unremembering, so they would recognize their obligation to the loyal Moluccan people. If historians did not teach the Dutch their colonial past, then Moluccan youth would do so.

Bosma argues that during the 1970s any sense of even weak "postcolonial consciousness" among the Dutch began to disappear from public discourse. ${ }^{59}$ At the same time, the arrival of new Dutch citizens from the Caribbean and Surinam, as well as the "infamous Moluccan train hijackings," became the postcolonial themes that dominated the media. ${ }^{60}$ We have seen how Thenu claimed that the aim of the hijackers had been to make their struggle for independence known to the Dutch and the rest of the world ${ }^{61}$ In this they were successful. ${ }^{62}$ The Dutch were appalled by the violent actions, especially by the abduction of children and execution of hostages. ${ }^{63}$ The image of the Moluccan changed from loyal soldier to problematic social group. ${ }^{64}$ Nevertheless, Steijlen describes the Moluccan actions as being "a catalyst." ${ }^{65}$

A team of researchers examined the impact the actions had on public opinion. They found that at first media showed understanding for the Moluccan actions, possibly caused by a "latent feeling of guilt." ${ }^{n 6}$ Newspapers provided much needed historical background, explaining "a forgotten and unsolved problem" of decolonization. ${ }^{67}$ However, the train and primary school actions of 1977 caused a loss of sympathy. ${ }^{68}$ Nevertheless, the actions did lead to "a certain mental decolonization among the South Moluccans as well as the Dutch." 69

The Moluccan actions provided the motivation for a number of television programmes and books that highlighted the intimate Moluccan entanglement with Dutch colonialism. One programme, followed by a book, complicated the narrative by providing a criticism of the collective memory propagated by supporters of the RMS. Ben van Kaam noted that only a minority of Moluccans had identified with the Netherlands. He called the idea that they had always been loyal for centuries a myth..$^{7} \mathrm{He}$

Ibid., 26.

Thenu, Korban, 49.

62 Steijlen, RMS, 156.

63 Ibid., 163.

64 Steijlen, "De Molukkers," 366.

65 Steijlen, $R M S, 156$.

66 Schmid et al., Zuidmolukse terrorisme, 95.

67 Ibid., 96.

68 Ibid.

69 Ibid., 121.

70 Van Kaam, Ambon, 9-12. 
demonstrated that many Moluccans supported the Indonesian revolution..$^{11}$ The attack on Ambon in $195^{\circ}$ had pitted Indonesian against Moluccan, but also Moluccan against Moluccan..$^{72}$ Van Kaam accused the Dutch authorities of perpetrating false history. ${ }^{73}$ However, he admitted that in 1950, for the Moluccans of the KNIL, "the world they knew collapsed."74

Van Kaam's book received wide-ranging admiring reviews. ${ }^{75}$ His argument gained support some years later in an academic study by two historians. The violence of the 1970s motivated Bosscher and Waaldijk to undertake their research. Their main argument was that the ideals of the RMS had only ever appealed to citizens in the Netherlands who could not accept the decolonization of Indonesia. ${ }^{76}$ This new interest in the plight of Moluccans never quite disappeared. The Dutch had been painfully confronted by an episode in their history of decolonization. By 1986, a historic agreement was reached between Moluccan authorities and the Dutch government that included the founding of a Moluccan Historical Museum in Utrecht. ${ }^{77}$ The Moluccan actions had been a costly but effective way of representing what had been hidden in unremembering.

\section{Postmemory Authors}

By the late 1970s, the Indo author Lin Scholte had created a small oeuvre of stories. Her book Bibi Koetis voor altijd (Bibi Koetis forever) from 1974 touched upon the Bersiap period and the absolute horror of October 1945, when anyone associated with Dutch rule became the target of bands of violent nationalist youths. ${ }^{7}$ On the other hand, her short story "Geen pardon voor saboteurs" ("No mercy for saboteurs"), from 1977, describes how Dutch soldiers execute a suspect without any due process. ${ }^{79}$

\footnotetext{
71 Ibid., 63-71.

72 Ibid., 142-144.

73 "Geschiedvervalsing over Ambon," Nieuwsblad van het Noorden, 9 July 1977.

74 Van Kaam, Ambon, 91.

75 "RMS: zaak van tegenstellingen en misverstanden," Leeuwarder Courant, 7 July 1977; “Geschiedvervalsing over Ambon," Nieuwsblad van het Noorden, 9 July 1977; Joop Morriën, "Ambon door de eeuwen," De Waarheid, 12 July 1977; Ben Herbergs, “Ambon door de eeuwen," Het Vrije Volk, 23 July 1977; G.J. Schulte, "Van Kaam en de Molukken," Nederlands Dagblad, 26 July 1977; Peter Schumacher, "Talloze Molukkers geloven historie van hum republiek niet," NRC Handelsblad, 2 July 1981.

76 Bosscher and Waaldijk, Ambon, 3, 108-110.

77 Steijlen, RMS, 195.

78 Scholte, Verzamelde romans, 354-361.

79 Ibid., 452-454.
} 
Scholte was a repatriate herself, but her biographical stories were based on the memories of the women of her parents' generation. In 1983, three new postmemory writers debuted in the Dutch literary scene. These secondgeneration authors problematized the silences and oblique references to loss that characterized the first generation's approach to decolonization. Each writer descended from repatriates, knew the Dutch East Indies primarily through stories, and was raised by means of Indisch norms involving a silent father who had been scarred by war. ${ }^{80}$ Adriaan van Dis described how the experience of the first generation came to dominate the world of the second generation: "Everything that you experienced as a child stood in the shadow of what they had experienced, without it being stated." Daan Vree puts it succinctly: "Children of the second generation grew up with this Indisch inheritance [...] synonymous with a war inheritance." ${ }^{82}$

\section{Jill Stolk}

Jill Stolk asks the rhetorical question: "Can you pass your dreams and nightmares onto your children without ever telling them?" 83 Her novel Scherven van Smargald (Shards of emerald) was dedicated to her father and opens with a declaration from the narrator that she wants to bring to the attention of all the World War Two experts how it is to have a father figure who, "cursed by four years in a POW camp, takes out his frustrations on his child." 84

The narrator, a young Indo girl, like Stolk herself, was unlucky enough to have facial features that looked Japanese, becoming a constant reminder to her father of the suffering he had endured in the Japanese prison camp, as if "his cells has been so infiltrated with the actual features of the oppressor $[\ldots]$ that he [...] had poisoned his soul and body" (12). Thus, his daughter's features carry the memory of his suffering written on her body, embodying the memory of humiliation and suffering.

Like many Indisch people, Stolk's narrator complains that the World War that they studied at school in the Netherlands was one of bicycles, tulips and the exploits of the brave resistance, but the teachers never described the tropical war of her father (10-11). When a minority war experience was

\footnotetext{
8o Van Zonneveld, "Indische literatuur," 158-159.

81 Van Zonneveld, “'Ik ben," 213.

82 Vree, "Het verleden," 37.

83 Stolk, Indië, 151.

84 Stolk, Scherven, 7.
} 
discussed, it was never the Indisch experience, but the Jews (81). Yet, the father in Stolk's story has been scarred by his suffering during the war and its aftermath, including being repatriated to the Netherlands. He takes out his frustration by being a tyrant at home. His violent outbursts are sometimes aimed at his daughter (20-24). Eventually, father and daughter make a journey to the place of his horrific memories, the Burma Railroad (32-34), and to the war cemetery of Kanchanaburi (39-47).

In his oral history of Indonesian independence, Kester Freriks writes that the interning in Japanese camps is a collective memory that overshadows all others among the Indisch community: "The echo of this continues to sound, not just in the lives of those concerned; [but] also in the lives of their children and even grandchildren." ${ }^{85}$ But, because there was little understanding for their experiences in the Netherlands, a way of speaking could not be found and victims of the camps became silent, the "Indische silence." Consequently, children were barred from accessing their pasts "like actors on a stage who have received no lines." ${ }^{86}$ He quotes an interviewee: "The story of the Dutch East Indies has always been the story of silencing [...] called Indische silence." The interviewee mentions that her own husband, "remained silent just about his whole life. He had been a volunteer during the police actions. That dirty war." ${ }^{87}$ Similarly, interviewee Ami Emanuel remembers how her father "never spoke about his experience" while her mother "remained silent as well about the war time, especially about the Bersiap. She spoke about her youth in the East Indies, but never about what came after." 88 A veteran says, "From the moment we arrived home [in Holland] the great Indische silence began.. ${ }^{89}$

Stolk indicates the many silences that peppered Indisch family life after decolonization. Not only does the father never open up about what he endured in the prison camp, but the family history remains shrouded in mystery. While the female narrator begins to explore her personal identity, she notices that her father "would never discuss my mother's ancestry" for clearly, there was evidence of Japanese blood. $9^{\circ}$ The young narrator becomes aware that her skin colour makes her different than the white children around her (69), but is outraged when her father tells her that she needs to do her best at school, because she is Indisch. She wonders does this reflect

\footnotetext{
85 Freriks, Echo's, 154.

86 Ibid., 155 .

87 Ibid., 163 .

88 Ibid., 253 .

89 Ibid., 296-297.

90 Stolk, Scherven, 66.
} 
a pride in being Indisch, or is it because they feel so inferior that they have to disprove the stereotype and demonstrate that, despite being Indisch, they can attain high achievement (74-75). Either way, she is burdened by the problems that her parents themselves could not solve. In a passage that provides a case study of the postmemory dilemma, Stolk writes: "because they, my parents, say it, I am forced to live with it. Even when I don't know what 'it' stands for. Because these children are my parents I must believe in their problems and they obviously become mine" (76).

This encapsulates the postmemory quandary of decolonization's second generation. Born in the early 1950s, in white, postcolonial Holland, they are raised in a country obsessed with reconstruction and convinced of its own innocence and victimization by Nazi Germany. There is little space for any contesting memory. Additionally, they are born into a minority community that has been dislocated. Intent on fitting in, their parents and grandparents submerge their own experience, while continually alluding to it. The second generation grows up aware of the presence of an absence. They know that their collective memory does not involve tulips and brave resistance, but that a terrible experience is unremembered. In their attempt to fit in they continual juggle unremembering with remembering. Stolk's narrator tells us: "I was good at forgetting. I was a master in forgetting" (83). But, she admits: "Gradually I discover that I forgot nothing" (93-94).

\section{Marion Bloem}

It is widely recognized that the publication of Marion Bloem's Geen gewoon Indisch meisje (No ordinary Indisch girl) in 1983 constitutes the beginning of a new postcolonial genre in Dutch literature, in which the second generation of Indisch repatriates problematize their own identity and question their community. ${ }^{91}$ It immediately gained the attention of a wide public, arriving "like a bomb."92 Influential critic Hans Warren called the publication "a literary event" and compared Bloem to Tjalie Robinson. ${ }^{93}$ Jaap Goedgebure compared her to Rob Nieuwenhuys and the great Du Perron. ${ }^{94}$ The publication of the book meant that the second generation of Indische-Dutch had "for the first time gained a voice in literature."95

92 Sophie Tak, "Individualiste tussen wal en schip: aanpassen of afzetten," Trouw, 2 June 2006.

93 Hans Warren, "Verbluffend debuut van Marion Bloem," Provinciale Zeeuwse Courant, 18 June 1983 .

94 Jaap Goedgebure, "De nauwe kloof tussen wal en schip," Haagse Post, 30 April 1983.

95 Van Rijnswou, Marion Bloem, 7. 
From the very first sentence, we know that we are dealing with a novel that is a memory work: "Events are past, but become now as soon as they become written down as stories. ${ }^{n 6}$ For Bloem, the act of writing is an attempt to stop the erasure of Indisch culture. ${ }^{97}$ Like a great deal of trauma literature, Bloem's narrative is fragmentary, non-chronological and decentralized. It lacks a unified main character, but instead has a trinity of two sisters, Sonja and Zon, and I ("Ik"). Sonja and Zon, though sisters, form the fragmentary aspects of a postcolonial personality who, due to the violence of decolonization and the displacement that was its consequence, is left decentred and wondering where she belongs. Bloem regards the most essential problem articulated in her work to be "[b]alancing between two cultures." ${ }^{8}$ Most significantly, the "I" in the book is burdened by the scars of her parents, a father who yearns for the lost East Indies and a mother intent on assimilation.

Bloem's search for a cultural identity echoes, on the one hand, Tjalie Robinson's acceptance of the idea of the mestizo. The "I" of the novel seeks out "the mongrel type that is a consequence of the colonial period" and seeks recognition for the fact "We are allowed to be here." 99 On the other hand, when Zon, who resists assimilation, hears of the schizophrenia of mestizos, she spends her days crying "[a]s if the theory applied to her" (83). A difference between Robinson, who had died in 1974, and the members of the second generation, like Bloem, is that this postmemory generation was raised in the Netherlands. For this generation, the problem had become that their Indisch cultural references were not based upon direct experiences, but on the experiences of their parents. These had been related to them via objects, photographs and stories, but also via silences. These silences hid and at the same time contained the pain of decolonization. Bloem's contribution to remembering decolonization is that she brings these silences to the fore.

Bloem also articulates the frustration of the younger generation of the Indisch community, that the Dutch have not learned their history. What puts the Indisch presence in the Netherlands into question is the ignorance of the Euro-Dutch. During a trip to Indonesia with her mother, Zon is approached by an American tourist, who asks: "Do you know what I like most about your country?" (157). This can be laughed off, an American who mistakes her for an Indonesian. Less forgivable is the case of her Dutch boyfriend, when he tells her that his mother is not used to Indonesians. She replies in 
frustration, "I am not an Indonesian. I am Indisch. (How often has she said this sentence?)" (24).

This frustration reflected the sad state of colonial history in the Netherlands at the time. Oostindie quotes Edy Seriese: "When 'Indisch' and 'Indonesian' are used interchangeably, then it means that Dutch people don't know their own history." ${ }^{100}$ Worse, the unremembered history of decolonization causes pain and frustration among the Indisch-Dutch, as when the father in Bloem's novel comes home and says: "Do you know what somebody at my work said? You are a traitor. You betrayed your own people and went and fought for the Dutch. I said, hey, are you crazy? What are you thinking? I am an Indisch-Dutchman." He is appalled to discover that a colleague "thinks for sure that I'm an Indonesian, or a Moluccan maybe."101 This exchange represents an ignorance that lies at the core of how the Dutch related to decolonization, an ignorance that the Dutch themselves are not aware of. Dark-skinned repatriates are Indonesians who went over to the other side. The newer generation, like Bloem, are the children of turncoats. Thus, the imagined sins of the father come to stain the lives of the children.

In the years preceding publication of Geen gewoon Indisch meisje, it was the Moluccans who had dominated the media's attention. References to Moluccans abound in the novel, revealing the prejudice that dominated colonial Indisch life. For the postmemory generation, it is frustrating to be mistaken for Indonesian. But, during colonial times, Indisch people were frustrated when they were put on a par with Inlanders or natives, because not only was Inlander a lower legal category, but they were generally thought to be inferior. Moluccans, or Ambonese, as they were known, were also considered inferior by the Indisch community. We are reminded of Fanon's "lactification." Bloem shows us the same phenomena at work among the Indisch community in the Netherlands. The Indo should not be mistaken for the Moluccan, for the Indo is more civilized, being closer to being white, having been the servant of colonial power and being descended from a white (fore)father and a native (fore)mother.

These old attitudes are present in the character of the mother, in Bloem's novel. We learn that the mother's father had a suspicion of conscripted soldiers, that he found Indisch men not good enough for his daughter and that he wouldn't even consider Indonesians or Ambonese (93). Zon finds that her mother shares this low opinion of Ambonese or Moluccans: to mistake someone for an Ambonese is an insult (116); the mother describes 
Ambonese as ugly, loud and bad-mannered (117); even the word Ambonese fills the mother with dread, because they refused to assimilate and they ruin things for the Indisch community that attempts to assimilate, but ultimately, because the "Dutch cannot tell the difference" (117). Zon has imbibed these prejudices of the older generation, rooted in the stratified society of the Dutch East Indies (116). She wondered how long will it take before her boyfriend can tell the difference between Indonesians, Moluccans, "and her sort" (33).

The year Bloem published Geen gewoon Indisch meisje (1983) also saw her debut as a film documentarist. Het Land van mijn Ouders (The country of my parents) premiered before the press in Amsterdam before appearing at the Utrecht Film Festival. ${ }^{102}$ It played before sold-out audiences at the Groningen Film Festival ${ }^{103}$ and was aired on television. The film made clear how the postmemory generation was dealing with the consequences of the parents' experiences and decisions made under the shadow of decolonization. The opening scene showed Bloem lacing up her ice-skating boots and an unsteady Bloem on the skating rink. It closed with a scene of Bloem at her Balinese dance lesson. In neither one is she completely at home. She is not the typical Dutch girl and neither is she the natural Indonesian dancer, but a person in between cultures.

A montage of homemade videos and interviews with family members explore the meaning of hybridity and what is means to be Indisch. In primary school, Bloem discovers that she is different than other Dutch children, yet when she first visits Indonesia, the people on the street call her Belanda (Dutch). Her mother is happy that they left Indonesia, leaving the poverty of the kampong behind, escaping the violence of decolonization. Her father's feelings are ambiguous. He loves Indonesia, despite the fact that he had fought against Indonesian nationalists during the war of decolonization. He left the country in 1950 because his wife was afraid. Bloem's aim had been to "break through the exclusiveness of World War Two."104 Her film complicated the national collective memory by demonstrating that among the Dutch population there were some who had not experienced the German occupation, but had endured other trials.

102 Max Smith, "Speurtoucht naar de Indische geaardheid," Amersfort Courant, 20 September 1983. 103 Paul Bollen, "Land van mijn Ouders: Marion Bloem en de 'stille kracht," Nieuwsblad van het Noorden, 23 December 1984.

104 Ineke Jungschleger, "Niet gewoon de dochter van de kleine Boeng," De Volkskrant, 8 October 1983 . 


\section{Adriaan van Dis}

Journalist and editor at the NRC Handelsblad, Adriaan van Dis had become a public figure by 1983 , thanks to his popular television chat show Hier is ... Adriaan van Dis (Here is ... Adriaan van Dis). At the end of that year, a limited edition of his first book, Nathan Sid, was sent as a New Year's gift to friends of the publisher. Months later, it was published in commercial format. The following year it was announced that the book had been the bestselling debut of the year. ${ }^{105}$ When, over ten years later, Van Dis returned to the topic in the novel Indische Duinen (Indische dunes), sales of the latter would break all literary records. ${ }^{106}$ Van Dis, thus, brought the problem of unremembering decolonization to the attention of hundreds of thousands of readers.

Nathan Sid straddles the border between novel and memoir, between fiction and fact. It can be read as an account of young Van Dis growing up in a family scarred by the Japanese occupation and traumatized by the loss of the East Indies. It is clearly a work of postmemory. The name "Sid" is a lightly disguised "Dis" and the first reviewer referred to the work as "youth memories of Adriaan van Dis. ${ }^{107}$ Another referred to Van Dis taking a magnifying glass to his own youth memories. ${ }^{108}$ Some were more circumspect, simply asking could Sid be Van Dis. ${ }^{109}$

A decade after Nathan Sid appeared, Van Dis published Indische Duinen, a substantial novel on the same theme. The names of the characters and most details remain the same. Many years later, Van Dis published a memoir of his recently deceased mother, Ik Kom Terug (I come back). Again, the outline of the family history, the names of the characters and memories of war and loss are consistent with the earlier two works. Paul Sars states bluntly: "Adriaan van Dis is Nathan Sid."110 Though he warns that it is a work of literary imagination, he admits that it is a work where a distinction between reality and fiction is dubious. ${ }^{111}$ Van Dis himself included a message near the end of a later edition of the book, in which he admitted that he

105 Nieuwsblad van het Noorden, 3 December 1985; De Telegraaf, 4 December 1985.

106 "Never before in the Netherlands had so many copies of a literary work been sold over two years as Indische Duinen (over 340,00o copies)." Sars, Adriaan van Dis, 100.

107 Nico Scheepmaker, "van Dis," Leeuwarder Courant, 17 January 1984.

108 Gerrit Jan Zwier, "Was ik maar een graspriet," Leeuwarder Courant, 6 April 1984.

109 "Adriaan van Dis in W. Pieterse," Het Vrije Volk, 16 February 1984.

110 Sars, Adriaan van Dis, 9.

111 Ibid., 68-71. 
had given Nathan Sid his own story of growing up in a house of repatriates where "[t]he war still raged." ${ }^{\text {"12 }}$

Due to his complicated family history, Van Dis once claimed: "I am postcolonialism." ${ }^{113}$ His Dutch mother, Maria, had left for the Indies in 1932 with her husband, a soldier in the KNIL who had been born to a Dutch plantation owner and a native woman. The couple had three daughters. During the Japanese occupation she had been interned with her daughters. Her Indo husband was executed by the Japanese. After liberation, while awaiting repatriation with her three daughters, she had met and begun a relationship with a former Dutch soldier. He had been married to an Indonesian woman who had divorced him according to Muslim law, though this divorce was not recognized in Dutch law and therefore he could not remarry. The new family unit of five were repatriated to the Netherlands in 1946, though Maria was now three months pregnant. The child born after arrival in the Netherlands was Adriaan van Dis. ${ }^{114}$ In this unusual constellation, Van Dis was in many ways the outsider - his three half-sisters had black hair and brown skin while he had fair hair and freckles. ${ }^{115}$ The sisters officially carried the name of their dead father; Van Dis, being illegitimate, officially had the maiden name of his mother. But all the family lived the fiction of sharing the name of Van Dis' father. It is the same family constellation in Nathan Sid.

The most obvious fact that gave Dis/Sid outsider status is that all family members had lived in the Dutch East Indies, while he had not. The Indies were present in Sid's home, with bamboo photo frames, batik, busts of Balinese women, colonial photos and huge pans in which his father prepared Indonesian food. ${ }^{116}$ At school he was proud to be from the Indies (7), though, in reality, he had left the colony in his mother's womb. As the first line of the book tells us, "Nathan had never been there, but he had been made there" (5). The family sang songs that they remembered from the Japanese internment camp, and Nathan sang along, hoping that this would make him belong, too (43). Hearing their stories of the time in the camp made him envious. (42-43). By learning their songs, hearing their stories and being surrounded by the objects that embodied their loss, Nathan felt for them, but at the same time was envious. They felt a sense of loss; he felt

112 Van Dis, Nathan Sid, 70.

11 Van Dis, "Squeezed between," 20. The original lecture can be watched on YouTube: https:// www.youtube.com/watch?v=_i8KzmvegFk, accessed 17 July 2016.

114 Ibid., 26-27. See also: Sars, Adriaan van Dis, 10-12.

115 Van Dis, Ik Kom Terug, 126.

116 Van Dis, Nathan Sid, 5. 
the loss of not being able to share their loss. This mirrors the childhood feelings of Van Dis himself, raised as the sole white child in a settlement of repatriated Indo families. "I really wanted desperately to belong with those war children, with the other colour and experience."117 Van Dis never visited Indonesia until he was 50 years old, yet, like other postmemory authors, he experienced the East Indies as a memory, mediated through family stories, food and photographs. ${ }^{118}$

We learn that Nathan's father, "Pa Sid," was a strict disciplinarian. He had spent months working on the infamous Sumatra railroad. He was left with a weak heart and a small pension. Worse, his home, the Dutch East Indies, had been "taken from him." Ominously, Van Dis writes: "His punishments were laborious." ${ }^{119}$ Nathan suffers regular physical punishments, because the war and the loss of the Indies has physically and mentally scarred his father. Van Dis wrote of his father, "He wanted to return to his garden, but he was stuck in a cage."120 Nathan's story represents the consequences of decolonization through the difficult relationship between an innocent boy and an angry and disappointed father, a relationship based on impossible demands from the father and the futile attempts of the son to please. As Van Dis told an interviewer, "Children of the second generation of war victims are obedient, eager to please, docile children.",21

At the same time, despite the stories that Nathan hears ("one big story bacchanalia" in Van Dis' later description), ${ }^{122}$ as well as songs and jokes about the war, something important remains unsaid, as if the stories and songs camouflage the real trauma. The stories are examples of unremembering, rather than remembering, marking the presence of an absence. They are traces or the embodied memories of something terrible. Nathan's sister Ada carries an embodied memory in the form of a scar on her hand, inflicted in the Japanese internment camp. The wound still hurt whenever it rained, and then "the war pulled at the bones of her fingers." 23 Nathan is aware that his father's health has been destroyed by the Japanese occupation, ${ }^{124}$

117 Van Zonneveld, "Ik ben," 208.

118 Van Dis, Indië, in De Indië Boeken, 565-566.

119 Van Dis, Nathan Sid, 13.

120 Van Dis, "Klagen," 30.

121 Interviewed by Ingrid Hoogvorst, "Ik heb erg veel van mijn vader gehouden," De Telegraaf, 23 Sepember 1994.

122 Van Dis, "Klagen," 30.

123 Van Dis, Nathan Sid, 43.

124 Ibid., 45-46. 
and his father's weak heart is an embodied reminder of great suffering, but, explanations are hidden behind tall stories, songs and jokes.

Unanswered questions fester. As Van Dis later commented, "One thing is clear: to deny what had happened, you saddle your children with a terrible past." ${ }^{125}$ Sars comments that the real truth was too painful to discuss; instead, carefully guarded secrets, "remain silenced, although they were conspicuously present." ${ }^{126}$ The work of Van Dis, beginning with Nathan Sid, is an example of working through these painful experiences. His later Indische Duinen and Ik Kom Terug highlight more emphatically how the second generation was burdened with the pain of their parents and how the need to expose the silences leads to obsession. Nathan Sid is a slight work, lightly told, despite the descriptions of the punishments that the young boy has to endure. But, it wasn't really the full story. Van Dis had to wait another decade before he was ready. As he admits: "[T]he courage and inspiration still had to ripen." ${ }^{127}$ When he finally told the story in Indische Duinen, the book's huge sales and the reaction of the Indisch community showed that he had touched a nerve: "I had evidently broken a long silence, and suddenly became their spokesman." ${ }^{.128}$

\section{Radio and Television, 1979-1988}

In December 1979, Chris van Esterik and Kees van Twist presented a fourpart radio programme on the war of decolonization, the goal of which was to fill in what was ignored in history textbooks. ${ }^{129}$ The programme presented soldiers describing military atrocities, offering a sympathetic account of those who had refused to serve in the army, as well as demonstrating how General Spoor had influenced Prime Minister Beel in his decision to unleash the first "police action" in 1947. The series was repeated in July 1980 , followed by the publication of a book with supplementary material. ${ }^{130}$

In the summer of 1983 , the Catholic Radio Broadcaster (KRO) ran a weekly series of five radio programmes, De kleine oorlog (The little war), directed

125 Hoogvorst, "Ik heb erg veel."

126 Sars, Adriaan van Dis, 13.

127 Van Dis, "Squeezed between," 35 .

128 Ibid.

129 Daar werd iets grootsch verricht: of hoe het Konikrijk der Nederlanden zijn grootste kolonie verloor, IKON, December, 1979.

130 Van Esterik and Van Twist, Daar werd. 
by Jaap Vermeer. ${ }^{131}$ The Nederlands Dagblad announced that the KRO was attempting to fill in some "blank pages" from history by giving attention to "war crimes."132 Introduced by historian Jan Bank, the first episode focused on reasons why men went to fight in the Dutch East Indies. The interviewees were men who volunteered, believing they would be fighting the Japanese, not defending the interests of the big plantations. A former volunteer tells that he had been in the resistance and that he volunteered because he wanted to do something like what the Canadians had done for the Netherlands. Other contributors went to war because they were called up. They never dreamed of objecting. They were victims of brainwashing, they said.

In the second programme, nine veterans shared their experiences. They agreed that they were converted to hard-handed methods after seeing terrible mutilations and butchery perpetrated by Indonesian nationalists. They admitted, you "set yourself up as the judge." They discovered that they were willing to go very far, in order to get information from prisoners. One described what happened to prisoners: "They were liquidated. Took them to the river."

In the third programme, a veteran tells of how one night they surrounded a village. The shelling began, and they were ordered to shoot everything that came running out. He told of how he grabbed a man and drowned him in the ditch. The next morning they killed hundreds. "Hundreds," he repeated. They killed all the men, women and children, then they burnt the village. A veteran compared their methods with those of the Germans.

The fourth programme focused on the sexual behaviour of the soldiers. Participants expressed their disappointment regarding the home front, which seemed to be more concerned with the sexual purity of the soldiers than with reports of violence. They compared relations with women with trade in livestock. Laundry maids were expected to provide sexual services. Women were stripped naked and forced to walk back and forth between the gaping soldiers. One veteran referred to women as the "spoils of war." They confirmed that they received no accurate information on venereal disease and no condoms. Soldiers attempted suicide when they suspected that they had picked up a venereal disease.

In the final programme, veterans reflected upon how they have learned to deal with their memories. They agreed that the memories can be shut away for a while in silence, but after the Hueting interview of 1969, and as the 
men entered their mid-5os, the memories that had been in the subconscious "burst forth." One asked, "How can I live with what I've done?"

In 1983, the newspaper Het Vrije Volk was under the editorship of Herman Wigbold, the man who had brought Hueting before the television screens in 1969. Not surprisingly, Het Vrije Volk published a number of articles on this radio series. The day after the first episode, an anonymous author claimed that the Dutch had committed "systematic war crimes" ("stelsmatige oorlogsmisdaden"), touching upon the issue that would come to dominate the discourse on remembering decolonization. Furthermore, the article mentioned the village of Rawagede and how, though not broadcast in the programme, soldiers had described how they had massacred the inhabitants of this Javanese village. ${ }^{133}$ Buried in the Excessennota in 1969, the name Rawagede would come to haunt the Netherlands well into the second decade of the twenty-first century.

Jaap Vermeer explained that his purpose had been to show what happened when young men were ripped from their homes at a critical point in their lives and inserted into an alien world, isolated from what was familiar. He blamed the Catholic Church for pressurizing political and military leaders so no condoms would be distributed and sexually transmitted disease would become rife. He admitted that had he been in similar conditions "all my principles would have ended in the rubbish bin."134

The KRO received just a hundred reactions over the weeks of the broadcast. ${ }^{135}$ Het Vrije Volk received one negative letter as a result of its positive review. ${ }^{136}$ However, this did not mean that dealing with decolonization had entered into calm waters. The term "war crimes" passed unnoticed by many when broadcast on summer afternoons on the radio. However, as we will see in the next chapter, it would prove to be a different affair when the most renowned historian of the land considered using the term.

The purpose of the five-part television documentary "Ons Indië" voor de Indonesiërs ("Our Indies" for the Indonesians) was to destroy the myth that Indonesian nationalism had been a creation of Japanese propaganda. ${ }^{137}$ With help from historian William IJzereef, the programme makers showed that

133 "Ex-trailleurs bekennen: 'Wij moorden kampong uit,' Het Vrije Volk, 20 July 1983. In 2011 a Dutch court found the Dutch military guilty of carrying out a mass muder in Rawagede (see the final chapter).

134 "KRO-Programmermaker Na Laatste Uitzending: 'Ik heb nu begrip gekregen voor die oorlogsmisdaden," Het Vrije Volk, 24 August 1983.

135 Ibid.

136 P.J. Wartena, "De kleine oorlog': grove insinuaties," Het Vrije Volk, 30 July 1983.

137 “Ons Indië" voor de Indonesiërs, NOS, 25 November 1984. 
European colonizers had been, in the words of an Indonesian interviewee, "Dutch dreamers" who had believed they could control the Indonesians forever. Dutch colonials, Indo women, pro-Dutch Moluccans, Indonesian nationalists, and for the first time, Japanese participants, were included in this oral history. The programme demonstrated the suffering endured by Europeans and Indonesians under the Japanese occupation. It showed that Sukarno and Hatta had cooperated with the Japanese, not as fascist collaborators, but walking a fine line to eventually complete Indonesian independence. Making use of Japanese propaganda films, the programme showed how Indonesian youth had been radicalized under the Japanese, but also argued that the Japanese had lost control of the situation by 1945 . The programme was a reminder that, despite the powerful draw of nostalgia tropique, the Dutch, had failed to become rooted in the archipelago and, in the eyes of Indonesians, remained resented outsiders.

Marion Bloem's Wij komen als vrienden (We come as friends) broke new ground. ${ }^{138}$ In this film, Bloem allowed five former Dutch soldiers who had gone over to the Indonesian side to tell their story. The documentary was composed almost entirely of interviews with the men, filmed on location in Indonesia and in the Netherlands. Never before had Dutch media allowed this point of view such an airing. One interviewee had escaped the German massacre of Putten. For many Dutch people "Putten" was synonymous with Nazi barbarity. This man tells how he witnessed a Dutch prisoner transport train arriving in Surabaya. When the hermetically sealed train was opened, it was discovered that dozens of the Indonesian prisoners had succumbed in the heat. "I thought, we are no better than the Germans in Putten," the man says. Other interviewees told of prisoners shot dead and villages burnt. One interviewee, Poncke Princen, was shown to have dedicated his life to defending human rights in Indonesia, resulting in him spending years in prisons and becoming estranged from his third wife and children, who moved to Holland for security. Ten years later, Princen would become a household name when an outcry arose among some veterans when Princen applied for a visa to visit the Netherlands.

In August 1985, 40 years after the Indonesian Declaration of Independence, a documentary in two parts called VeertigJaar na Dato - Nederlands Indië (Forty years later - Dutch East Indies) was broadcast ${ }^{139}$ Some of the Indonesian interviewees were the same nationalists who had appeared in Kiers' Indonesia Merdeka (1976). However, the Dutch participants were not

138 Wij komen als vrienden, VPRO, 16 December 1984.

139 VeertigJaar na Dato: Nederlands-Indies, AVRO, 12 August 1989 and 19 August 1985. 
influential decision-makers but rather "innocent" victims. The first part showed how Indonesian nationalists like Sukarno had cooperated with the Japanese with the goal being Indonesian independence. A number of Dutch prisoners of the Japanese spoke of the barbaric conditions that they suffered in the camps, including torture. One interviewee, who had been among the first allied troops to enter a prison camp after the surrender of Japan, broke into tears as he exclaimed that everyone has heard of Buchenwald and the Nazi camps, but what he had seen had been just as bad: "You can never forget something like that."

One week later, the documentary covered the violent period of the Bersiap in 1945-1946. It told the "forgotten" story of Dutch former prisoners of the Japanese, especially women and children, being set upon by Indonesian mobs and murdered. Photos showed mutilated bodies, mass graves, groups of bound captives being killed. An interviewee told of finding bits of mutilated bodies strewn across the street and of discovering scores of bodies stuffed down a drinking well. He added that witnessing such scenes drives one mad with the urge to avenge. The programme ended with scenes of civilians boarding ships to be repatriated and concluded with an interviewee admitting that her stories of cruel hardship had been ignored in the Netherlands.

In 1988, the public broadcaster VPRO put out a ten-episode radio documentary on the war of decolonization. The fourth episode, of 24 April, Afscheid van Indië:De oorlogsmisdaden (Goodbye to the Dutch East Indies: The war crimes), was a litany of excessive violence, told mainly by five Dutch veterans. ${ }^{140}$ Again we hear of villages burnt or attacked by heavy artillery, summary executions, prisoners abused, beaten and tortured with electric shocks. The Hueting interview was quoted, as was an interview with Westerling in which he justified summary executions. One veteran told of his involvement in a massacre in which they eliminated 80 per cent of the male population of a village, comparing it with the German massacre in Putten. Another told of how he has started collecting signatures of veterans who want to write an apology to the people of Indonesia. No historian participated in this programme, but sociologist and veteran J.A.A. van Doorn, when asked why no Dutch war criminals had been prosecuted, explained that it was because the top politicians in the Netherlands bore the responsibility for war crimes.

Connerton argues that there is a type of forgetting that is part of a process leading to "the formation of a new identity." ${ }^{141}$ Submerging memories of 
recent traumas seemed a necessity for the first generation of repatriates, like Robinson and Nieuwenhuys, in order to survive and forge a new identity in their new homeland. But, the pain of suppressing memories did not go unnoticed by the second generation. Connerton writes of "humiliated silence" that leads to collective shame. ${ }^{142}$ The repatriates had experienced the humiliation of Japanese occupation, of being evicted from their homeland and arrival in a country where the inhabitants demonstrated little interest in their plight. Assimilation involved silencing those shameful aspects of one's past.

The violence of Moluccan actions during the years from 1970 to 1978 represented a wake-up call. Historical wounds festered in Dutch society, even when ignored. The work of postmemory writers began undoing the process of unremembering. Radio and television networks demonstrated courage in publicizing the controversial issue of Dutch war crimes. Veterans proved to be willing to speak about their memories, frequently using a framework that they had internalized, comparing their actions with those of the Germans and, specifically, the atrocity of Putten. But what about the historians?

\section{Bibliography}

Akihary, Huib. "Van Almere tot de Zwaluwenburg. Molukse woonoorden in Nederland." In Tijdelijk Verblijf: De opvang van Molukkers in Nederland, 1951, edited by Wim Manuhutu and Henk Smeets, 40-73. Amsterdam:De Bataafsche Leeuw, 1991. Bartels, Dieter. "Can the Train Ever be Stopped Again? Developments in the Moluccan Community in the Netherlands Before and After the Hijackings." Indonesia 41 (April 1986): 23-45.

Bloem, Marion. Geen gewoon Indisch meisje. Amsterdam: De Arbeiderspers, 2012 [first published Haarlem: In de Knipscheer, 1983].

Bootsma, Peter. De Molukse Acties: Treinkapingen en gijzelingen 1970-1978. Amsterdam: Boom, 2015 .

Bosscher, Doeko and Berteke Waaldijk. Ambon - Eer en Schuld: Politiek en pressie rond de Republiek Zuid-Molukken. Weesp: Van Holkema en Warendorf, 1985.

Chakrabarty, Dipesh. "History and the Politics of Recognition." Manifestos for History, edited by Keith Jenkins, Sue Morgan and Alun Munslow, 77-87. London and New York: Routledge, 2007. 
Connerton, Paul. The Spirit of Mourning: History, Memory and the Body. New York: Cambridge University Press, 2011.

Dis, Adriaan van. De Indië Boeken. Amsterdam: Augustus, 2012.

Dis, Adriaan van. Ik Kom Terug. Amsterdam: Augustus, 2014.

Dis, Adriaan van. "Klagen met een mopje." De Gids 1 (2011): 24-31.

Dis, Adriaan van. Nathan Sid. Amsterdam: Augustus, 2010 [1983].

Dis, Adriaan van. "Squeezed between Rice and Potato: Personal Reflections on a Dutch (Post) Colonial Youth." In Shifting the Compass: Pluricontinental Connections in Dutch Colonial and Postcolonial Literature, edited by Jeroen Dewulf, Olf Praamstra and Michiel van Kempen, 20-37. Newcastle: Cambridge Scholars Publishing, 2013.

Esterik, Chris van and Kees van Twist. Daarwerd iets grootsch verricht: of hoe het Koninkrijk der Nederlanden zijn grootste kolonie verloor. Weesp: Heureka, 1980. Fabius, Jan. Zwart op Wit - Liquidatie van een Imperium: Een beeld van de na-oorlogse regeringsbeleid in Nederland, ontleend aan de Nieuwsbrief. Amsterdam: Buijten en Schipperheijn, 1954.

Freriks, Kester. Echo's van Indie: De onafhankelijkheid van Indonesië in verhalen en herinneringen. Amsterdam: Athenaeum-Polak \& Van Gennep, 2015.

Hirsch, Marianne. The Generation of Postmemory: Writing and Visual Culture after the Holocaust. New York: Columbia University Press, 2012.

Hoffman, Eva. "The Long Afterlife of Loss." In Memory: Histories, Theories, Debates, edited by Susannah Radstone and Bill Schwartz, 406-415. New York: Fordham University Press, 2010.

Kaam, Ben van. Ambon door de eeuwen. Baarn: Anthos, 1977.

Manuhutu, Wim. "Help Ambon in Nood. De rol van het particulier initiatief bij de RMS en de opvang van Molukkers in Nederland.” In Tijdelijk Verblijf: De opvang van Molukkers in Nederland, 195, edited by Wim Manuhutu and Henk Smeets, 74-87. Amsterdam: De Bataafsche Leeuw, 1991.

Manuhutu, Wim and Henk Smeets, eds. Tijdelijk Verblijf: De opvang van Molukkers in Nederland, 1951. Amsterdam: De Bataafsche Leeuw, 1991.

Manusama, Johan A. "Political Aspects of the Struggle for Independence." In The South Moluccas: Rebellious Province or Occupied State, by Jan C. Bouman et al., 49-63. Leyden: A.W. Sythoff, 1960.

Oostindie, Gert. Post Koloniaal Nederland: Vijfenzestig jaar vergeten, herdenken, verdringen. Amsterdam: Bert Bakker, 2010.

Prins, Baukje. Gemengde Gevoelens: Molukse en Nederlandse klasgenoten in de jaren zestig. Amsterdam: Van Gennep, 2014.

Prins, Jan. "Location, History, Forgotten Struggle." In The South Moluccas: Rebellious Province or Occupied State, edited byJan C. Bouman, 9-47. Leyden: A.W. Sythoff, 196o. 
Rijnswou, Saskia van. Marion Bloem. Amsterdam: De Arbeiderspers, 1993.

Sahetapy, Abe. Tawanan (gevangenschap). Amsterdam: Joop Ririmase, 1982.

Sars, Paul. Adriaan van Dis: De zandkastelen van je jeugd. Nijmegen: SUN, 1996.

Schmid, A.P., J.F.A. de Graaf, F. Bovenkerk, L.M.Bovenkerk-Teerink and L. Brunt. Zuidmolukse terrorisme, de media en de publieke opinie: Twee studies van her Centrum voor Onderzoek van Maatschappelijke Tegenstellingen. Amsterdam: Intermediair, 1982.

Scholte, Lin. Verzamelde romans en verhalen. The Hague: Stichting Tong Tong, 2007.

Smeets, Henk. “De plaats van keuze.” In Tijdelijk Verblijf:De opvang van Molukkers in Nederland, 1951, edited by Wim Manuhutu and Henk Smeets, 7-16. Amsterdam: De Bataafsche Leeuw, 1991.

Smeets, Henk. "Sprongen door de Molukse geschiedenis." Indische Letteren 10, no. 1 (1995): 3-12.

Steijlen, Fridus. "De Molukkers." In Een Open Zenuw: How wij ons de Tweede Wereldoorlog herinneren, edited by Madelon de Keizer and Marieke Plomp, 361-370. Amsterdam: Bert Bakker, 2010.

Steijlen, Fridus. RMS: Van ideaal tot symbool-Moluks nationalisme in Nederland, 1951-1994. Amsterdam: Spinhuis, 1996.

Stolk, Jill. Indië was alles. Alles. Bergen: Van Stockum Bonnville, 1996.

Stolk, Jill. Scherven van Smargald. The Hague: Moesson, 1983.

Thenu, Cornelius. Korban: het verhaal van een Molukse activist. Amsterdam: De Arbeiderspers, 1998.

Vree, Daan. "Het verleden voorbij: Jill Stolk in het licht van de naoorlogse dekolonisatie." Indische Letteren 15, no. 1 (2000): 37-46.

Wesseling, Henk L. "Post-Imperial Holland." Journal of Contemporary History ${ }_{15}$, no. 1 (1980): 125-142.

Zonneveld, Peter van. 'Ik ben de schatbewaarder. Ik ben de fantast:' Gesprek met Adriaan van Dis.” Indische Letteren 18, no. 4 (2003): 207-220.

Zonneveld, Peter van. "Indische literatuur van de twintigste eeuw." In Europa buitengaats. Koloniale en postkoloniale literaturen in Europese talen, 2 vols, edited by Theo D'haen, vol. 1, 133-159. Amsterdam: Bert Bakker, 2002.

\section{Radio}

Daar werd iets grootsch verricht: of hoe het Koninkrijk der Nederlanden zijn grootste kolonie verloor. IKON, 1979.

De kleine oorlog. KRO, 1983

Het Spoor Terug: Afscheid van Indië. VPRO, 1988. 


\section{Television}

Antenne: Korban. EO, 1998.

Dutch Approach: Gebroken belofte. NPS, 2000.

De Kampong staat in brand. RVU, 1989.

Het Land van mijn Ouders. IKON, 1983.

'Ons Indië'voor de Indonesiers. NOS, 1984.

Oorlog en Verzet in Nederlands-Indië. RVU, 1989.

De Tijd Staat Even Stil: De Zuidmolukse droom. NCRV, 1994.

Veertig Jaar na dato: Nederlands-Indië. I. AVRO, 1985.

Veertig Jaar na dato: Nederlands-Indië. II. AVRO, 1985.

De Verandering. NOS, 2015.

Wij komen als vrienden. VPRO, 1984 [Released in cinemas in 1984.] 


\title{
$6 \quad$ Loe de Jong Controversy
}

\begin{abstract}
During the 1970 and 1980 os Dutch historians of colonialism continued to produce works on the war of decolonization that failed to provide any sustained analysis of actual fighting, creating the impression that the war was fought exclusively by diplomatic means. The work of Jan Bank formed a modest exception. This silence of Dutch historians can be understood by using the metaphor of the guild. The historical guild reinforced and rewarded the virtues of avoiding controversy, speculation and sweeping statements. This systemic unremembering was broken by the work of IJzereef in 1984 and especially by Loe de Jong in the late 1980 . De Jong was forced to endure vehement criticism and legal proceedings. But unremembering was at last being publically contested.
\end{abstract}

Keywords: Loe de Jong, unremembering, historical guild, Dutch East Indies, decolonization, collective memory

A heated historiographical debate on decolonization started in the mid-1980s and continued into the mid-199os. At its centre was Loe de Jong, presenter of De Bezetting and official historian of World War Two. The meaning of Dutch history was fought out in the public arena, in the law courts but most of all in the pages of the press. It revealed how misunderstood and unrecognized members of the Indisch community and the veterans had come to feel as they fought for their place in collective memory.

Television had elevated Loe de Jong to the position of informal history teacher of the Netherlands. From 1969 onward, a growing number of volumes of De Jong's Het Koninkrijk der Nederlanden in de Tweede Wereldoorlog began appearing in scholarly and popular editions. The publication of each new volume was "a national occasion" launched at an official press conference. ${ }^{1}$ Bodewijn Smits estimates that 80,00o Dutch households own a complete

Doolan, P.M.M., Collective Memory and the Dutch East Indies. Unremembering Decolonization. Amsterdam: Amsterdam University Press 2021 DOI: 10.5117/9789463728744_CHO6 
set of 29 volumes. ${ }^{2}$ De Jong became a household name with his work, a monument in his own lifetime.

By the mid-1980s, De Jong turned his attention to the East Indies. On 30 October 1984, the eleventh section of his giant work, divided into two volumes, arrived in the bookstores. It unleashed a memory war comparable to, if not greater than the Hueting controversy. By its end, in the late 1980s, participants in historical culture could no longer bury themselves in a state of unremembering.

\section{A Slow Change Coming}

One might have been forgiven for predicting that Van Doorn and Hendrix's analysis from 1970 would be followed by numerous in-depth studies of Dutch systematic violence. Instead, it remained the standard work on the decolonization war for the next half century. ${ }^{3}$ By the end of the 1970s, other publications about decolonization were published, but had shortcomings.

C. Smit's De Dekolonisatie van Indonesië (The decolonization of Indonesia), despite the promising title, was a light work, meant as an introduction for teachers, "not too deep, but still complete."4 Smit's third book on the subject was pruned of all critical remarks. He began with Sukarno's Declaration of Independence in 1945, ignoring the rise of Indonesian nationalism and Dutch repression. ${ }^{5}$ It offers an example of what Frederick Cooper labels "a light switch view of decolonization. ${ }^{\prime 6}$ With no context given, like the flick of a light switch, the declaration occurs and everything changes. Bogaerts and Raben argue that this approach "is not feasible and is indeed [...] rarely used."7 Rare perhaps, but in the Dutch historiography not out of the question. Smit's Eurocentric approach becomes obvious considering that more than half of the book provides an analysis of eight "dramatis personae" - all Dutch, as if the struggle for Indonesian independence was exclusively the result of Dutch miscalculations in the absence of any Indonesian agency. ${ }^{8}$

Harry Poeze's lengthy, fact-filled and painstakingly documented doctoral dissertation, Tan Malaka: Levensloop van 1897 tot 1945 (Tan Malaka: Life from

Ibid., 485 .

Oostindie, Hoogenboom and Verwey, “The Decolonization War," 259-26o.

Smit, De Dekolonisatie, 5 .

Ibid., 11.

Cooper, Colonialism, 19.

Bogaerts and Raben, "Beyond Empire," 15.

Smit, De Dekolonisatie, 53-154. 
1897 until 1945) was published in 1976. It was the first ever full-length study of the Indonesian Marxist revolutionary Tan Malaka, who played a prominent role in the Indonesian revolution and the war of decolonization. Most of the volume dealt with Tan Malaka's years in exile - in the Netherlands, the Soviet Union and across East Asia. The book ends with Malaka heading for Jakarta in August of 1945, the eve of the war of decolonization. ${ }^{9}$ This was something of a cliffhanger ending. Poeze declared his intention was to publish, in the foreseeable future, a second volume dealing with Malaka's role in the conflict. ${ }^{10}$ Het Vrije Volk reported that Poeze intended to publish the second volume in under two years. ${ }^{11}$ Alas, it was to be over three decades. The second volume had by then mushroomed into three more volumes of over 2,00o pages. The reason given for the delay was that Poeze had been distracted by his professional responsibilities at the publishing department of the Royal Netherlands Institute of Southeast Asian and Caribbean Studies (KITLV) in Leiden. ${ }^{12}$

J.A. Jonkman had been Minister for the Colonies from 1946 until 1948. His Nederland en Indonesië beide vrij: Gezien vanuit het Nederlands Parlement (The Netherlands and Indonesia both free: Seen from the Dutch parliament) was the second volume of his political memoirs. Like Van Mook, he had been a member of the De Stuw group and claimed that they had worked towards creating a Kingdom of the Netherlands in which all parts - metropole and colonies - would be equals. ${ }^{13}$ Imprisoned in a Japanese camp, he heard that Sukarno was collaborating with the Japanese, but claimed that he never thought harshly of Sukarno. He could understand why Sukarno, under the circumstances, would choose to work for the Japanese for the betterment of his own nationalist cause (17). He claimed that he was entirely surprised in 1946, when Prime Minister Beel asked him to be Minister of the Colonies. He accepted the position only out of a sense of duty (35).

Throughout the description of his time in office, he stressed, he always felt duty bound to abide by the constitution. This gave him an aversion to radical decision-making (47-52). He was consistently against the use of force, but admitted that it was unimaginable as a government not to have an army; therefore, soldiers were drafted and transported to Indonesia (61-62). He praised Van Mook for what he had achieved by 1946, but constitutional

1 Peter Post, “Tan Malaka: de Rode Pimpernel van Zuid-Oost-Azië,” Het Vrije Volk, 25 March 1976. 
reform stumbled because of opposition from the Catholic People's Party (KVP) (79). With the deterioration of the situation by mid-1947, he realized military action might be needed, but discussions with General Spoor convinced him that this could be limited. This was, he emphasized, a police action, not a war (100-111). He emphasized "we old De Stuw men" had always followed a pro-Indonesian policy (115).

Jonkman argued that the intervention by the United Nations lacked legal basis as the "police action" was an internal affair of the Netherlands (116). By early 1948, the former De Stuw men (Van Mook, Logemann and Jonkman) were undermined by the KVP (142-143). Later that year he gave up his post to become a member of the Senate of the Dutch parliament for the Labour Party (153). He was taken by surprise by the second "police action" of December 1948 (158). This action he condemned (165).

Jonkman's account received widespread positive reviews. Even the communist De Waarheid seemed to absolve him of all personal responsibility for the fiasco of $1945^{-1949 .}{ }^{14}$ The following year, L.G.M. Jaquet's memoir of his time in Indonesia, Aflossing van de Wacht (Changing of the guard) appeared. Jaquet had spent his entire adult life in government diplomatic service, first in the Dutch East Indies, later in the Netherlands, receiving a knighthood in $1972 .{ }^{15}$ Some months later, he was appointed director of the Ministry of Foreign Affairs. ${ }^{16}$

The former colonial official stated that this work was simply a fragmentary attempt to place his memories against a broad background. ${ }^{17}$ Jaquet's work was not devoid of criticisms of the Dutch approach to decolonization. During the late 1930s, one of Jaquet's duties had involved regular face-to-face meetings with Sukarno, who was under internal exile. Sukarno is portrayed as well-read, intelligent and charming. A man who espoused anti-fascist and anti-Japanese views (21-23). The fact that the colonial government did little to channel Sukarno's talents into helping protect the colony from the Japanese and then failed to evacuate Sukarno in order to keep him out of the hands of the Japanese, was a colossal failure (23-28). While it may have been impossible to avoid the inevitable, Jaquet concluded that "a more reasonable policy regarding nationalism before the war could have led the post-war developments into calmer waters" (28).

\footnotetext{
14 “Onontbeerlijk bijdrage in Indonesië-discussie," De Volkskrant, 21 March 1977; J.R. Soetenhorst, "Memoires Jonkman: boeiende aanvulling," NRC Handelsblad, 7 April 1977; Joop Morriën, "Jonkman en de koloniale oorlog," De Waarheid, 16 April 1977.

15 “Dr. L.G.M. Jaquet," NRC Handelsblad, 22 July 1972.

16 “Dr. L.G.M. Jaquet," NRC Handelsblad, 13 December 1972.

17 Jaquet, Aflossing, 9.
} 
Regarding the process of decolonization, Jaquet complained that the Dutch view of Sukarno as a Japanese puppet had serious political consequences (206). His severest criticism was towards members of government who misread the international situation - there are no excuses, he suggests, for not being aware of what the international repercussions would be for turning to the military option (294-295).

Jaquet was a political insider who had spent his life in government civil service. His carefully worded memoir offered some cautious lessons. The reviewer, A. Kamsteeg, focused on the lesson that ran through Jaquet's book: Dutch leaders had failed to consider Indonesian nationalism. ${ }^{18}$ Cees Fasseur, chief author of the Excessennota, reviewed Jaquet's work twice. Both reviews are remarkable for what they leave out. In his review in Itinerario, a historical journal from the University of Leiden, he failed to mention Jaquet's criticisms of the Dutch and colonial governments. The closest he got was mentioning that Jaquet "provides some interesting remarks on his contacts with [Sukarno] and on attitudes towards him of certain Dutch officials, whose occasional pettiness Jaquet finds reprehensible." ${ }^{19}$ More surprising, is Fasseur's review in the NRC Handelsblad. He mentioned that Jaquet doesn't have much new to say about the post-war period of decolonization, but this makes the early chapter "all the more nice" for the anecdotes that they share about Sukarno. Fasseur is pleased that these show a sympathetic side to Dutch rule! ${ }^{20}$ Jaquet had cautiously provided a critique of Dutch policy that Fasseur ignored.

In 1979, Professor J.H. van Stuijvenberg edited an economic history of the Netherlands to be used as a textbook at universities. The final chapter, written by Fasseur and Henri Baudet, covered the economic history of the Dutch East Indies in 38 pages. Only 6 pages were given to the period from 1945 to $1949 .{ }^{21}$ However, Baudet returned to the subject together with a team of political scientists and economic historians from Amsterdam and Groningen. In 1983, they published the first economic history of decolonization to appear in book form. It provided an analysis of the relationship between government and private industry and an evaluation of the economic consequences of Indonesian independence for the Netherlands. ${ }^{22}$

18 A. Kamsteeg, "Meer aansluiting bij Indonesisch nationalisme had veel ellende kunnen voorkomen," Nederlands Dagblad, 17 November 1978.

19 Cess Fasseur, review of Dr. L.G.M. Jaquet, Aflossing van de Wacht: Bestuurlijke en politieke ervaringen in de nadagen van Nederlandsch-Indië, Itinerario 3, no. 1 (1979): 94.

20 C. Fasseur, "De Nadagen van Tropisch Nederland," NRC Handelsblad, 28 April 1979.

21

Baudet and Fasseur, "Koloniale bedrijvigheid," 342-347.

Baudet and Fennema, Het Nederlands belang. 
In 1982, J.C. Bijkerk published a political study of the role of Van Mook in the dying years of the Dutch colony. It was hagiographical in style. The protagonist is well intentioned, but misunderstood: "At that moment a lonely man was sitting at his desk in his study in the official residence. He stared ahead and thought about the most recent reports."23 Bijkerk had spent World War Two in a Japanese camp (155). He considered the Dutch East Indies to have been an outstandingly well run colony and regarded Sukarno as untrustworthy and cowardly (158-163). He gave a detailed account of the violence unleashed upon Europeans by Indonesian nationalists in 1945, admitting that this made the pro-Dutch Ambonese troops "trigger-happy" (186-194). Amidst the violence, Van Mook stood "head and shoulders" above everyone else (218). However, we are repeatedly told that right-wing leaders in the Netherlands worked to undermine Van Mook (191-194, 207-209, 217, 230). Bijkerk absolved the military, including Westerling, of any suspicion of violent excesses (251-252). He noted that even Van Mook saw that there was no alternative to military violence when he ordered the first "police action" in 1947 (256).

Jan Bank of the University of Amsterdam penned an outstanding detailed study of the role of the Catholic Church and its party, the KVP, during the Indonesian revolution, Katholieken en de Indonesische Revolutie (Catholics and the Indonesian revolution). Bank remarked that the "fruitfulness" of English-language studies of the Indonesian revolution formed a stark contrast with Dutch historiography, which had failed to make any progress, despite the fact that for Dutch history it was a "crucial subject." ${ }^{24}$ He argued that the leaders of the KVP had formed a conservative lobby that made significant political and diplomatic errors. Bank considered the KVP leader Romme's famous article on the Hoge Veluwe Conference in De Volkskrant in 1946 to have been "a fierce attack" on the decision to talk with the Indonesian republican nationalists (160). Flying in the face of the facts, KVP leaders like Sassen, Beel and Romme knowingly took huge risks (400). Their greatest error, Bank maintained, was misreading the anti-colonial attitude of the US (403). Their miscalculations delayed Indonesian independence and contributed to needless warfare. Bank mourned the fact that Catholic emancipation in the Netherlands formed an obstacle to the national emancipation of Indonesia (493). 
Bank's work marked a milestone in the critical historiography of Dutch decolonization, for he dared to raise the issue of violent excesses by Dutch military personnel, be it in a modest 7 out of nearly 500 pages. He argued that while socialists and communists, and even the leadership of Protestant churches, demonstrated their horror at the reports of Westerling's tactics, responses from the Catholic authorities were mixed (425-427). He furthermore argued that Catholic army chaplains remained deliberately silent when it came to reports of military brutality (427). Additionally, while communists and socialists in the metropole, as well as leaders of various Protestant churches, demonstrated concern when reports of atrocities appeared in the Dutch press in 1948 and 1949, KVP leader Romme did little to intervene when he personally received evidence that these atrocities were taking place, believing these were simply the accidental effects of warfare (429).

Katholieken en de Indonesische Revolutie was a massive volume. P.F. Maas's Indie Verloren, Rampspoed Geboren (East Indies lost, disaster born) was a slim collection of three essays examining the crucial period of Dutch decision-making between November 1948 and February 1949. The professor's main argument was that the Catholic leaders Romme, Sassen and Beel had fallen victim to their own moral certainty and by February 1949 the Drees cabinet had formulated a policy best described as "muddling through."

Ronald Gase's Beel in Batavia appeared in 1986. Based on recently opened archives, the book covered the political dealings among the Dutch parties in The Hague following the election of July $1948 .{ }^{26}$ Gase conducted a close analysis of the negotiations among Dutch leaders that led to Van Mook's removal and a reorientation in policy (125-175). He was in no doubt that Van Mook was sacked "because the domestic political constellation in the Netherlands had made his going necessary" (173). The result was disastrous and, like Bank and Maas, Gase attributed the responsibility to the KVP and its triumvirate of leaders, Romme, Sassen and Beel (175; 219). Van Mook's replacement in Batavia, former Prime Minister Louis Beel, was convinced that he was working according to God's plan (291). Lacking any experience of Indonesia, he fell increasingly under the influence of the Dutch military leadership and opted for a military solution that was futile (237-286). Ultimately, Gase argued, all political parties "and the Dutch as a people" failed in Indonesia (291). 
These works shared a number of shortcomings. Firstly, there is the intense Eurocentric (Hollandcentric) point of view. Indonesia is almost a sideshow. The works are written by Dutch men and are concerned exclusively with Dutch men. As Raben writes, they mainly focus "on discussions in Dutch politics or the military and diplomatic entanglements in the archipelago."27

It is significant that, with the exception of seven pages in Bank, war is absent in these accounts. No battles are mentioned, no casualty figures given, none of the blood and shattered bones that make up warfare. They offer insights and Baudet, Bank, Maas and Gase produced academically excellent work. However, their representations of the biggest war in Dutch history lack representation of warfare. They hide the unpleasant act of killing.

From Van Mook and De Kadt, through Gerbrandy and Smit, to Bank and Maas, the war, according to Dutch chroniclers and historians, had been fought in the corridors of power in Batavia and The Hague. We encounter negotiations in Batavia, the Hoge Veluwe, Linggadjati, Malino, Renville and The Hague, are made privy to insider deals and backstabbing in the Netherlands and we continually encounter the personal rivalries of the leading Dutch diplomatic players. Indonesian nationalist leaders earn cameo appearances. However, we are rarely informed of the soldier's or civilian's experience.

With historians' reluctance to confront the "blood and guts" of a war, it is not surprising that others from outside academia leapt into the breach. Ewald Vanvugt published an article in De Volkskrant, in which he wrote of the massacre by Dutch soldiers of 96 Indonesian rebels, including resistance hero Ngrurah Rai. ${ }^{28}$ Ad van Liempt wrote in Vrij Nederland about the mass murder in Galoeng Galoeng. Liempt correctly argued that the massacre had "never become history."29

Perhaps the practitioners of the Dutch historical profession, especially the colonial experts, could not account for the madness of colonial war within their professional symbolic framework. They simply fell back on what they knew - the analysis of power exercised by politicians through rational means. They withdrew into an arena where horizons were bound by the walls of conference rooms. They consequently constructed safe representations of the conflict and unremembered the ultimate condition of warfare - the act of killing.

27 Raben, "Hoe wordt men vrij?," 15.

28 Ewald Vanvugt, "Maar jij, een Nederlander, wat doe jij hier op ons veld van eer," De Volkskrant, 23 November 1985 .

29 Ad van Liempt, "De Massamoord van Galoeng Galoeng," Vrij Nederland, 31 January 1987. 


\section{Silence of the Guild}

We find the act of killing articulated graphically in the works of Beb Vuyk, Vincent Mahieu, Albert van de Hoogte, Job Sytzen, Jan Schilt, Jan Varenne and Jacob Zwaan, remembered and represented by documentarists like Wigbold, Kiers and Vermeer. Trouillot suggests that the silencing of historical memory is rarely the result of political conspiracy, but is nearly always structural..$^{30}$ Therefore, the historiographical silence must have been structurally rooted within the small world of Dutch colonial historians. In 2002, Stef Scagliola summarized the factors that she considered account for the lack of interest in decolonization among Dutch historians. The most telling is her assertion that historians were considered scholars of integrity who avoided "sweeping statements." Consequently, even the royal family consulted prestigious historians like Fasseur, Bank and Wesseling when it came to Indonesian affairs. Such positions of influence would not have been achieved had they demonstrated "contrarian views." She adds, "I don't condemn this; I simply suggest that that is how it works." ${ }^{11}$

People often do not see what is blatantly obvious. Margaret Heffernan offers dozens of cases of organizations that suffer from "wilful blindness." The need to belong to the in-group, she argues, leads to conformity. In a closed group, conformity is appreciated and organizational silence becomes the norm, with disconfirming views seldom heard.$^{32}$ Robert Cribb coined the term "circles of esteem" to describe the phenomenon in which scholars of Indonesia create a sense of common purpose, supporting each other's work, thereby making the work of individuals from outside the circle "vulnerable to charges of charlatanry, to the suspicions of being a maverick or loose cannon." ${ }^{33}$ Such a process makes disconfirming points of view difficult.

Sociologists Pierre Bourdieu and Jean-Claude Passeron have written of how the power to bestow educational credentials serves a social function, "quite analogous to that which befell nobility titles in feudal society."34 This academic system forms an almost closed environment, self-policing and self-perpetuating. ${ }^{35}$ Numerous scholars have likened the organization of historical scholarship to that of a guild ${ }^{36}$ No less a historian than Marc

Trouillot, Silencing the Past, 106.

Scagliola, Last van de oorlog, 191-193.

Heffernan, Wilful Blindness, 165-173, 300.

Cribb, “Circles of Esteem," 292.

Bourdieu and Passeron, Reproduction in Education, $\mathrm{x}$.

5 Ibid., 198.

36 Brante, "Sociological Approaches," 137-138; Fish, “One More Time," 278-279. 
Bloch warned against the temptation of writing "for the private use of guild." Furthermore, he warned of historians acting like "the rules committee of an ancient guild, who codify the tasks permitted to the members of the trade." 37 Louis Mink argues that academic historians act like a guild that exercises the power to differentiate between their own serious work and that of popular or amateur histories..$^{38}$ Edward Said argued that scholars create "a guild solidarity." 39 References to a guild mentality are widespread among Said's works. ${ }^{40}$ He argued that the discourse among professors "becomes a jargon, speaking only to the informed, keeping them essentially in a state of acquiescence."41 Said argued that the guild is ultimately responsible for deciding, "Who writes? For whom is the writing done?"42

We have seen Scagliola's assertion that Dutch historians had an aversion to sensationalist topics and sweeping statements. This is supported when we consider the point of view of essayist Rudy Kousbroek. He accused Dutch historians of timidity, arguing that they "only express themselves when something is, not just historically, but politically no longer disputed." 43 Said argued that a characteristic of the scholarly guild mentality is to believe that the real scholar is "preoccupied only with ideas, eternal values, and high principals." 44 This allows guild members to use "scholarly honour and integrity" to deny "political partisanship" and reject "critical outsiders." According to Anne-Lot Hoek, these "strategies of avoidance" were used by the Dutch academic elite to avoid the controversial topic of Dutch excessive violence in Indonesia. ${ }^{46}$ In a radio conversation with Rudy Kousbroek, Remco Raben highlighted a problematic aspect of Dutch colonial historical culture - the avoidance of the moral side of history and a "philatelic" obsession with registering and summarizing a narrow range of European sources. ${ }^{47}$

Mink, "The Theory," 3-8.

39 Said, "Opponents," 6-17.

40 For instance: Said, Orientalism, 207, 326, 342, 343; Said, Covering Islam, 150, 152, 170. He also uses the term "barony" (Orientalism, 346) and "corporate institution" (Orientalism, 3).

41 Said, "Europe," 39-40.

42 Said, "Opponents," 1.

43 Kousbroek, Oostindisch Kampsyndroom, 290.

44 Said, Covering Islam, 140.

45 Ibid., 150.

46 Anne-Lot Hoek, "Rengat, 1949 (Part 2)," Inside Indonesia 125, 12 September 2016, https:// www.insideindonesia.org/rengat-1949-part-2, accessed 27 February 2021.

47 Geschiedenisgasten:Remco Raben en Rudy Kousbroek OVT, VPRO Radio, 14 July 2002. 
Trouillot agrees that a characteristic of the guild of historians is that it prides itself in the purity of its academic work free from political opinions. ${ }^{48}$ It creates parameters within which research takes place, archives the sources and limits what can be debated. The tendency is towards producing "a closed corpus." ${ }^{.99}$ Young historians are initiated into what constitutes significant issues and what should be passed over in silence. Those who pass through the gates of the masters and doctorate degrees internalize the values of the guild and it becomes the ambition of every new member "to conform to guild practice. ${ }^{\prime 0}$ In the case of the Dutch, this was successful. Hoek argues that the younger generation of historians "appeared to lack the radical attitude necessary to make the story [of Dutch violence] part of the national discourse." ${ }^{1}$

Frances Gouda, American trained herself, was quoted by Lizzy van Leeuwen, as arguing that Dutch historians "form a guild" and this closed group perpetuated the uncritical myth of the superior form of Dutch colonialism, ignoring important studies of the Indonesian revolution that were published abroad..$^{2}$ Australian historian Joost Cote agrees that Dutch historians cannot tolerate interference from outsiders when it comes to their colonial history, referring to the "self-referential academic environment" of which the heartland is Leiden University and the Royal Netherlands Institute of Southeast Asian and Caribbean Studies (KITLV). ${ }^{53}$ Similarly, trying to describe the rough treatment foreign scholars of Dutch history receive in the Netherlands, American historian Benjamin Schmidt playfully remarked, "the dikes and dunes of the Low Countries [...] are designed to keep outsiders at bay." 54 At a presentation in Leiden in 2016, American historian Jennifer Foray argued that Dutch colonial historians engaged in an "endless rhetorical loop" by claiming that Dutch imperialism is exceptional and therefore "only those aware of this exceptional status" (i.e. certain Dutch historians) are qualified to study it. ${ }^{55}$ Indeed, historian Louis Zweers referred to my

48 Part of this passage first appeared in Paul Doolan, "Decolonising Dutch History," Imperial and Global Forum (blog), Centre for Imperial and Global History, University of Exeter, 16 November 2016, https://imperialglobalexeter.com/2016/11/16/decolonizing-dutch-history/, accessed 10 December 2016.

49 Trouillot, Silencing the Past, 19.

50 Ibid., 56 .

51 Hoek, "Rengat."

$5^{2}$ Lizzy van Leeuwen, "Gordelroos van Smaragd," De Groene Amsterdammer, 19 October 2016.

53 Cote, "Strangers," 86.

54 Schmidt, "Dikes and Dunes," 85.

55 Foray, “Comparatively Exceptional," 90. 
work as "inmenging" or "interference. ${ }^{56}$ The Belgian historian David van Reybrouck remarks that, when writing his recent history of the Indonesian War of Independence he, as an outsider, had to justify himself before his Dutch colleagues "hundreds of times." 57

Henk Schulte Nordholt admits that, despite isolated efforts, the KITLV in Leiden "remained well into the 1970s an old-fashioned bastion of Dutch orientalism. ${ }^{58}$ Martin Kuitenbrouwer argued that various disciplines in Leiden underwent decolonization soon after Indonesian independence. 59 But when it came to historiography as practised at the KITLV, he admitted, "decolonization and internationalization of historiography was more limited." ${ }^{60}$ Some of the institute's leading historical practitioners were "strongly focused on the pre-war, traditional historiography," exhibiting little appreciation for "new socio-historical publications." ${ }^{61}$

The world of historians in Leiden was a pleasant, informal circle. Scholarly careers could be built with a tap on the shoulder. Eminent Leiden historian Henk Wesseling confessed that, in the beginning of the 196os, because he had the right contacts, he received a grant to complete a dissertation without writing a proposal and eventually received an appointment to a lectureship without applying for a job. ${ }^{62} \mathrm{He}$, in turn, helped the career of Cees Fasseur, who in 1977 was appointed (without applying) Special Professor in the History of West European Overseas Expansion within one year of his achieving a PhD. ${ }^{63}$ Fassuer's ignorance of Indonesian languages did not prevent him from becoming Professor of Indonesian History in Leiden in 1986. ${ }^{64}$ Looking back at his career, Fassuer admitted, "I never really had to formally apply for any position. ${ }^{65}$

Decolonization had been greatly ignored by historians. By the mid-197os, Smit had published three histories of the conflict, as well as editing Schermerhorn's journal in 1970. ${ }^{66}$ But, having worked in the Dutch East Indies

56 Louis Zweers, 6 February 2017 (13:04) comment on Caroline Drieenhuizen, "Veranderde Perspectieven: Een Discussie over Dekolonisatie in een Indonesische Context," Koloniaalverleden, voortdurende erfenis: Indonesië en Nederland (blog), 29 December 2016.

57 Van Reybrouck, Revolusi, 17.

58 Schulte Nordholt, "Locating," 41.

59 Kuitenbrouwer, Dutch Scholarship, 183-19o.

60 Ibid., 204.

61 Ibid., 204-205.

62 Wesseling, Van Toen en $\mathrm{Nu}, 207-208$.

63 Fasseur, Dubbelspoor, 158.

64 Ibid., 186.

65 Ibid., 304.

66 Schermerhorn, Het dagboek. 
as a lawyer, Indonesia was more a personal interest for Smit, his main work concerning the documentary history of Dutch diplomacy in the nineteenth and twentieth centuries. Lijphart published The Trauma of Decolonization in 1966. Born and raised in the Netherlands, Lijphart was awarded a scholarship to study in the United States when he was nineteen. He began research for a $\mathrm{PhD}$ in political science at Yale University, never returning to live or work in the Netherlands. The Trauma of Decolonization was based on his $\mathrm{PhD}$ dissertation, written while teaching at a small American college. In other words, he was working outside the guild, in isolation, which is why he stumbled across his topic almost accidentally ${ }^{67}$ Neither Smit nor Lijphart had been Leiden educated. The works of Paul van 't Veer and Van Doorn and Hendrix were significant, but Van 't Veer was a journalist and Van Doorn and Hendrix were sociologists. With the likes of Bank and Baudet we see the beginnings of the historical study of decolonization in the 1980s. But even here, the military aspects of the conflict are mostly avoided; only Bank mentions the issue of war crimes.

Let us look at how guild mentality operated. In the Hueting interview of 1969 , the Dutch were confronted with descriptions of widespread atrocities carried out by their soldiers. The government commissioned a report under Fasseur. Fasseur had been born and partially raised in the colony. He attended grammar school in Leiden before entering Leiden University and joining the Leidsch Studenten Corps, the traditional Leiden student association. In 1969, he dutifully published the Excessennota. He studiously avoided using the term "war crimes." He concluded that "excesses" had been incidental. Fasseur did feel more research was needed, but cautiously published this opinion under a pseudonym. ${ }^{68}$ This ensured his career would not be spoilt by the expression of a critical attitude.

In the coming years, he published works on the Dutch East Indies, keeping clear of the subject of war crimes. He was appointed to professorships in Leiden, where students undertook research under his supervision, none of which touched on war crimes. Eventually he became the biographer of the royal family, rewarded by Queen Beatrix with exclusive access to the archive of the royal household, the only historian ever to have been given such an honour. When he died in 2016, the KITLV referred to him as a colonial historian who "carried out ground-breaking research on the cultivation 
system in nineteenth-century Java.. ${ }^{\prime 69}$ His final, posthumously published book was a biography of the imperialist Gerbrandy. Although he made some mildly critical remarks of Gerbrandy's role during decolonization, his conclusion heroizes Gerbrandy and fails to mention Indonesia. ${ }^{70}$

Hoek writes that when Scagolia criticized Fasseur for his role in ignoring Dutch war crimes, he reacted so badly that she deleted the reference to him in her $\mathrm{PhD}$ dissertation because it might have damaged her position in the network of historians. Hoek quotes Scagolia describing Fasseur's attitude as being "the discretion of the ruling class: look away from things that make you uneasy."71 Hoek claims that "the entire political and social establishment carries the responsibility" for lacking the willpower to investigate and remember the period of decolonization. ${ }^{72}$ Fasseur wrote that after 1969 , he never considered undertaking any further investigation into Dutch war crimes because it "wasn't challenging enough," adding the rhetorical question, "Why drag all of the outrages that were perpetrated back and forth and all the concerned victims into the light?"73 This is an extraordinary question for a historian to ask.

In 1969, thanks to Fasseur's work, the Dutch public could look away from the issue of war crimes. It is an example of Said's "cult of expertise and professionalism" used to "make invisible" the collaboration "between the ideas and scholarship, on the one hand, and the world of politics, corporate and state power, and military force on the other."74

The guild was fairly isolated from external pressures. Its leaders imposed the norms that led to its continuity, meaning that any change would be slow. The equilibrium could be broken only when disturbed by a strong outside force. The Hueting interview was a rupture coming from outside. However, because other institutions - the government, political parties, the Indisch community, the military - when it came to remembering decolonization, were conservative, the guild of historians could perpetuate unremembering. None within the guild had the strength, courage or imagination to break out of the circle of esteem and represent the war as an arena of mass killing. Soldier-novelists offered an insight into the bloody gore of war. But the

69 “Cees Fasseur (1938-2016)," KITLV, http://www.kitlv.nl/cees-fasseur-1938-2016/, accessed 20 January 2020.

70 Fasseur, Eigen meester, 493-536, 555-561.

71 Anne-Lot Hoek, "Iedereen wist het. Niemand kon het zeggen," NRC Handelsblad, 16 September 2016.

72 Anne-Lot Hoek, "Historici, stel de juiste vragen over NL-Indie," NRC Handelsblad, 2o June 2015.

73 Fasseur, Dubbelspoor, 146-147.

74 Said, "Opponents," 3. 
attention of academic historians and memorialists remained fixated on the, perhaps no less gory, corridors of power in The Hague and Jakarta.

\section{Willem IJzereef}

In 1982, a book was published, Westerling: De eenling (Westerling: The loner), that, similar to Westerling's earlier memoir, reads like a boy's adventure story. The purpose was to clear Raymond Westerling's name. The book included photographs and documents, including a telegram from General Buurman van Vreeden to Westerling's superior, Colonel de Vries, permitting De Vries to order other groups to use Westerling's methods..$^{75}$ This showed that orders had come from high command and any atrocities that had occurred had been committed, not by Westerling himself, but by other groups misusing his methods. The author argued that Westerling did everything possible to protect the innocent with his quick justice. ${ }^{7}$ Historian Jaap de Moor dismisses the book as a mixture of fact and fantasy, written to justify Westerling's actions. ${ }^{77}$ Decades after the war, Westerling felt he needed to clear his name because the history of the conflict had yet to be written by any academic historian.

Between 1982 and 1984, the insistence that the war had been an arena of mass killing found a representation in the work of a young historian. Willem IJzereef had just graduated in contemporary history when Groniek, the student-edited historical journal of the University of Groningen, published his overview of the role of the press in the so-called South Celebes affair. As he described it, information regarding atrocities by special Dutch forces on the island of South Celebes was well known and available. It could be expected that someone would investigate the historical circumstances of the atrocities. Yet, despite the occasional discussion, historians had mainly remained silent on the issue..$^{7}$

Two years later, IJzereef's more substantial De Zuid-Celebes affaire: Kapitein Westerling en de standrechtelijke executies (The South Celebes affair: Captain Westerling and extrajudicial executions) appeared. In the acknowledgements, he thanked the Ministers of General Affairs, Foreign Affairs and Defence for having given him permission to access "all secret 
civil and military archives of the former Dutch East Indies authorities." 79 Despite the title, less than half of the book directly concerned Westerling. IJzereef spent more than half of the book setting the scene, demonstrating how the Australian occupation after the Japanese surrender deteriorated into a situation of violent lawlessness. This was partially due to Dutch policy of arresting and interning moderate Indonesian nationalists, leading to an increase in the influence of the more violent supporters of Sukarno (68-73). Tensions led to the Dutch resorting to excessive violence, shooting suspects without due process, using electric shock torture and mutilating prisoners during interrogation (79-80). By December 1946, with the situation almost out of control, it was decided to send in the special forces under Westerling. Involved in this decision were civil leader Van Mook; military leader General Spoor; leader of the judiciary Procurator-General Felderhof; the resident of South Celebes, Lion Cachet; and local army boss Colonel De Vries (93). The implication was that these men were responsible for the bloody consequences of this decision.

IJzereef gave a graphic account of the "Westerling method." As Westerling himself had claimed in his early memoir, this consisted of gathering intelligence, then breaking the power of the terrorists by applying summary justice in the form of on-the-spot executions, followed by winning the support of the people by restoring law and order (96-98). IJzereef gave a summary of Westerling's first three operations, resulting in 35,61 and 58 summary executions, respectively. There was no evidence that the summary killings were based on intelligence gathering (99-103). Victims seemed to have been picked on the spot (103).

Reports of Westerling's fourth operation reached the Dutch public when Vrij Nederland published an account by an eyewitness. IJzereef demonstrated that this report suggested that the Westerling method was arbitrary and chaotic and included a description of Westerling shooting off five toes of a victim before killing him (102-103). This proved to be a propaganda coup for the enemies of the Dutch, reaching the halls of the United Nations where the figure of 40,000 fatal victims was spread (108).

IJzereef argued that officials in Batavia were aware of what was happening and justified these illegal methods (109-112). Eventually, as the policy of summary executions was extended and subordinates of Westerling began to apply it in an almost indiscriminate manner, leaders in Batavia became uncomfortable. Under the command of Jan Vermeulen, about 700 Indonesian villagers were executed, including scores who had been taken from prisons 
(123-127). Van Mook compared such methods with those used by the Germans and Japanese during World War Two (130). Nevertheless, he did not stop the campaign. Instead, under Vermeulen, 364 villagers were massacred in Galoeng-Galoeng (133-134). It was the summary execution of a local rebel leader who was an aristocrat that finally led the authorities in Batavia to end the campaign (133-137). IJzereef estimated that the campaign had resulted in 3,130 Indonesians being executed (141). He concluded that this method of fighting was "completely illegal" (138).

IJzereef devoted the final 20 pages of his work to examining the aftermath of the South Celebes affair, a process in which we see unremembering at work. Vrij Nederland had brought the affair to the public's attention (148). Minister Jonkman when asked for clarification, gave answers that were vague and the public's attention quickly diverted towards the first "police action" (149). IJzereef noted that Romme, the Catholic leader, had been in South Celebes at the time and must have known what was going on, and IJzereef provided documentary evidence showing that other Catholic politicians had been well informed, including Prime Minister Beel. They hoped that this would never become known to world opinion (148).

Van Mook initiated an investigation into Westerling's methods in 1947, with the creation of a commission under K.L.J. Enthoven. IJzereef suggested that its organization left a lot to be desired (146). Family members of the victims of Dutch military violence were not interviewed (150). The Enthoven Report was completed in 1948 and concluded that incidental excesses had taken place on South Celebes. Further investigation began in 1949, but it ceased with the handover of sovereignty in December 1949. Meanwhile, the Enthoven Report was simply filed by the Dutch parliament. During the next 20 years, no parliamentarian ever requested to see it (151).

In early 1949, members of the Dutch Labour Party called for further investigation. This resulted in the Van Rij and Stam Report in 1954. Van Rij and Stam concluded that there had been no evidence that those summarily executed by Westerling and his followers had been guilty of any crime and that the Dutch actions "had had nothing to do with jurisprudence" (153). The Minister for Justice decided that the report contained nothing that would justify prosecutions; the report was shelved without parliamentary discussion and without the nation's media or public being informed (153). Consequently, those in Batavia and The Hague who bore political responsibility for the atrocities were never investigated (160). IJzereef judged:

The South Celebes affair was a political and military excess. The military illegally maintained the method of summary executions introduced by 
Westerling, politicians and soldiers made decisions, including decisions over the fate of prisoners, that could not be defended within any legal framework. (159)

Here was a book about a war that actually offered representations of a war. It was the bravest attempt yet by a historian to undo decades of unremembering. Still, it should be noted that IJzereef avoided the term "war crimes," instead using the more acceptable "excesses." Joop Morriën of the communist De Waarheid emphasized IJzereef's verdict, that the South Celebes affair was a political and military excess. ${ }^{80} \mathrm{~B}$. Lulofs, editor of the conservative De Telegraaf, compared IJzereef to a spoilt child for his insistence that Westerling killed between 20,000 and 40,000 victims, a claim that IJzereef never made. ${ }^{81}$ A reviewer in the Nieuwsblad van het Noorden praised IJzereef for managing to reclaim some "remarkable facts" about Dutch brutality. ${ }^{82}$ Some months later, Ger Vaders admitted IJzereef's work produced in him outrage and anger against Catholic leaders Romme and Beel. ${ }^{83}$ A reviewer in the Leeuwarder Courant warned that the book contained "shocking passages," noting that the killings in Pare-Pare and the massacre in Galoeng-Galoeng formed the "dramatic deep point" in Dutch military brutality. ${ }^{84}$ Morriën returned to IJzereef's book, this time focusing on how the political leaders were implicated in the policy of "systematic cruelty." His review carried a photograph of Romme alongside a photograph of Westerling, a montage that implied they were both equally guilty. ${ }^{85}$ Within a couple of years, IJzereef's book was referred to as "the standard work" by the liberal NRC Handelsblad. ${ }^{86}$ A decade later, Graa Boomsma, writing in the same newspaper, referred to it as a "ground-breaking study." 87

80 Joop Morriën, "Zuid-Celebes affaire was een militair en politiek exces," De Waarheid, 10 July 1984 .

81 B. Lulofs, "Den Haag Brief," De Telegraaf, 14 July 1984.

82 Harry Wubs, "Groninger historicus belicht rol Westerling," Nieuwsblad van het Noorden, 7 July 1984 .

83 Ger Vaders, "Geweld en de zindelijke burgerheren," Nieuwsblad van het Noorden, 21 September 1984 .

84 "Standrecht kostte 5,182 Indonesiërs het leven," Leeuwarder Courant, 3 September 1984.

85 Joop Morriën, "De wreedheden van Westerling waren de authoriteiten bekend," De Waarheid, 10 December 1984.

86 Herman Vuijsje, "Wat heeft gebeurd geweest, moet vergeet," NRC Handelsblad, 13 December 1986.

87 Graa Boomsma, "Het verleden blijft actief, het woekert door, barst naar buiten," NRC Handelsblad, 26 May 1994. 
Yet no reviewer seemed aware that Westerling himself had openly boasted of his deeds in his published memoir of $195^{2}$.

\section{Loe de Jong, Volume 11 a}

The editors of the newspaper Trouw could hardly hide their excitement: "The book that a whole lot of Dutch people have been impatiently looking forward to is available today in the bookstores." They added that the author, Loe de Jong, had made use of 59 advisers or co-readers, including two Indonesian professors, and they had read his text and given him feedback. ${ }^{88}$ The first reviews of Volume 11a of Het Koninkrijk der Nederlanden in de Tweede Wereldoorlog (The Kingdom of the Netherlands during World War Two) appeared the same day.Joop Morriën summarized De Jong's main argument and expressed agreement regarding his thesis of "the double tragedy" - that the Dutch had miscalculated the pre-war power of Indonesian nationalism and that they were woefully unprepared for war with Japan. ${ }^{89}$ The review in Trouw was positive, praising the dramatic structure, suggesting that De Jong had opened up his work to another new audience. ${ }^{90}$ Van Wijnen expressed his wholehearted agreement with De Jong, that in the historical drama of the collapse of the Dutch empire in Asia, only the left-wing parties in parliament "do not have to be ashamed of their behaviour." ${ }^{11}$ De Kok, in the Haagsche Courant, a newspaper with a large Indische readership, mentioned that the book provided a rehabilitation of the Indisch-Dutch population. ${ }^{92}$ Ben Maandag embraced the main lesson that the Dutch should be ashamed of how they behaved in colonial times. ${ }^{93}$

However, some reviewers paid close attention to the foreword, in which De Jong gave space to two of his co-readers, who expressed disagreement with his approach. None of De Jong's team had ever before gone public with their disagreement. The Leeuwaarder Courant headlined with, “Dr. L. de

88 "Nieuw deel De Jongs geschiedschrijving uit," Trouw, 30 October 1984. Throughout the publication, De Jong made use of a group of advisors. In total, 227 co-readers made 100,00o critical suggestions pre-publication (Smits, Loe de Jong, 513).

89 Joop Morriën, "Government doof en blind voor nationale beweging," De Waarheid, 30 October 1984.

90 J. Kuijk, "De Jong verlegt zijn blik naar Indie," Trouw, 30 October 1984.

91 H.A. van Wijnen, "Links hoeft zich niet te schamen voor de koloniën," Het Parool, 31 October 1984.

92 G. de Kok, "De Jong en Multatuli," Haagsche Courant, 3 o October 1984.

Ben Maandag, "Een dubbele tragedie," Het Vrije Volk, 3 o October 1984. 
Jong Wrote a Different Book Than Two Advisers Called For." ${ }^{14}$ De Volkskrant published a positive review from Jan Bank, which included a discussion of the disagreement, ${ }^{95}$ but also published a separate article headlining with news of the "conflict." ${ }^{\text {"6 }}$ Some reviewers found themselves siding with the criticisms of the two advisors. The NRC Handelsblad carried two reviews. One praised De Jong's achievement, but accused him of simplifications when it came to the rise of Indonesian nationalism and the Dutch response. 97 The other was extensive in its criticism, claiming that De Jong kept the achievements of the Dutch colonial governments hidden and ignored the progressive missionary work of the churches during the twentieth century. ${ }^{8}$ A day later, the Algemeen Dagblad ran an interview with one of the dissenting advisers, R. Kwantes, quoting him as saying "Brugmans and I believe that De Jong should have mentioned more of the positive aspects that the Dutch have carried out in Dutch East Indies."99 The emphasis had shifted from the actual contents of De Jong's book (over 1,200 pages), to the dissenting opinion expressed in seven paragraphs of the foreword.

In the coming weeks, resistance to De Jong's views of colonial society hardened, and sympathy for the "Indisch" point of view grew. Lulofs of the conservative De Telegraaf offers a case in point. His review, published on the day of the book's appearance, was positive. Some days later, in his editor's column, he returned to the subject, this time mentioning the dissenting advisors Brugmans and Kwantes, who had both worked in the colonial service in the former Dutch East Indies. Lulofs now argued that De Jong did not have adequate knowledge of colonial society, because he had no first-hand experience of it. ${ }^{100} \mathrm{~A}$ week later, his criticism was more pointed: "[T]here is too much Indonesian disturbance and too little Indische organization; there is too much Indonesian revolution and too little Dutch-Indische national unity."101

94 P. Boltendal, "Dr. L. de Jong schreef een ander boek dan twee adviseurs bepleitten," Leeuwarder Courant, 30 October 1984.

95 J. Bank, "L. de Jong scheidt illusie en werkelijkheid in Indie," De Volkskrant, 30 October 1984.

96 "De Jong in conflict over elfde deel oorlogsgeschiedenis," De Volkskrant, 3 o October 1984.

97 R. Soetenhorst, "De Jong verzamelde schat van gegevens in goedlopend verhaal," NRC Handelsblad, 30 October 1984.

98 F. Groeneveld, "Nederlands tijdperk in Indië door een anti-koloniale bril beschouwd," NRC Handelsblad, 3 o October 1984.

99 Karel Bagijn, “Twee medewerkers van De Jong hebben bezwaren tegen boek," Algemeen Dagblad, 30 October 1984.

100 B. Lulofs, "Indie," De Telegraaf, 3 November 1984.

101 B. Lulofs, "Deel 11a," De Telegraaf, 10 November 1984. 
In De Volkskrant, Peter Hoefnagels begged readers to remember that Indische people were just ordinary people and "should not be judged in one breath together with the colonial structure and the behaviour of the governments under which they lived." He added that these people were "displaced persons" and only after decolonization had they become "wrong" colonials. ${ }^{102}$ De Jong had used the simple framework of "good" Dutch and "bad" Germans and "bad" Dutch collaborators in De Bezetting and the earlier volumes of Het Koninkrijk der Nederlanden in de Tweede Wereloorlog. Hoefnagels suggested that this ran aground when it came to the Dutch East Indies. Volume 11a seemed to mark all colonials, by the fact of their birth, as "wrong." Even Peter Schumacher of the left-wing De Groene Amsterdammer claimed that De Jong had created a twisted picture of colonial society. ${ }^{103}$

Historian $\mathrm{H}$. Abels was mainly very positive, pointing out criticisms only in De Jong's history of the pre-European period, while pronouncing this volume as showing De Jong at his best. Regarding the Brugmans and Kwantes disagreement, Abels concluded that they were ideologically motivated and had not yet dealt with the loss of the colony. ${ }^{104}$ However, other academics were critical. Elsbeth Locher-Scholten attacked De Jong for his careless methodology. She pointed out factual errors, but worse, she argued that De Jong misused quotations to make the narrative livelier. ${ }^{105}$ Worst of all, the book was filled with judgements. ${ }^{106}$ The motivations for this was simply to increase the readability. ${ }^{107}$ Another specialist, P. Drooglever, co-editor of the sourcebook Officiële Bescheiden, was critical. He referred to 11a as being less reliable than it should be, because of its tone and emphasis. ${ }^{108} \mathrm{He}$ gave examples of what he considered to have been isolated incidents, but which De Jong used as the basis for generalizations. ${ }^{109} \mathrm{He}$ considered the work to be "sour and one-sided,"110 as well as "too highly dramatic."111

102 Peter Hoefnagels, "Kolonialen waren gewone mensen," De Volkskrant, 13 November 1984. 103 Peter Schumacher, "Een onevenwichtig en slordig Indisch deel," De Groene Amsterdammer, 9 January 1985 .

104 H. Abels, "Prof. L. de Jong en Indonesië," Skript: historisch tijdschrijt 7, no. 1 (1985): 59.

105 E.B. Locher-Scholten, review of Het Koninkrijk der Nederlanden in de tweede wereldoorlog, vol. 11a, by L. de Jong, Bijdragen en Mededelingen betreffende de Geschiedenis der Nederlanden 101, no. 2 (1986): 266.

106 Ibid., 267.

107 Ibid., 266.

108 P. Drooglever, review of Het Koninkrijk der Nederlanden in de tweede wereldoorlog, vol. 11a, by L. de Jong, Bijdragen tot de Taal-, Land en Volkenkunde 142, no. 2/3 (1986): 351 .

109 Ibid., $35^{2}$.

110 Ibid.

111 Ibid., 354 . 
The most significant criticism emerged from the self-designated mouthpiece of the Indisch community. Originally founded by Tjalie Robinson as Tong-Tong, the magazine was now named Moesson and under the editorship of Ralph Boekholt. De Jong's biographer Boudewijn Smits is incorrect when he claims that this group had been "born and raised in the former Dutch East Indies." ${ }^{112}$ Many, including Boekholt himself, had been raised in the Netherlands. Nevertheless, they strongly identified with the former colony. Their negative review (published with the initials AvL), appearing in three monthly sections, accused De Jong of being blinded by socialism ${ }^{113}$ and being far too subjective. ${ }^{114}$ They reported that the older among them considered De Jong's judgements to be "hurtful."15 Months later, Moesson published a short article, signed by Boekholt and Tjalie Robinson's widow, Lilian Ducelle, announcing that Moesson was joining with other plaintiffs in order to sue the Dutch state. Their aim was to force the state, as De Jong's employer, to withdraw and destroy all copies of Volume 11a and to persuade De Jong to rewrite his account. In order to achieve this they had founded the Comité Geschiedkundig Eerherstel (Committee for Historical Rehabilitation). ${ }^{116}$

Already in the mid-1950s, Tjalie Robinson had written, in a number of private letters, that the Indo needed a Dutchman to write his history, in order for the colonial population to have its honour restored. ${ }^{117}$ For decades, the Indisch community had felt that their narrative and specific identity was unremembered by historians. However, when at last their memory was due to be rehabilitated and assumed into the national narrative, by no less a figure than the admired national historian, their high expectations were dashed. Boekholt summarized their complaint: it was "painful that they are depicted as the colonial evil in historical writing that is published by the state." ${ }^{118}$ After the court rejected the claim of the Committee for Historical Rehabilitation, Boekholt added that it was "unhealthy when Indisch people

112 Smits, Loe de Jong, 747 .

113 AvL, "Het Koninkrijk der Nederlanden in De Tweede Weredoorlog 11a: Nederlands-Indië," Moesson, 15 November 1984.

114 AvL, "Het Koninkrijk der Nederlanden in De Tweede Weredoorlog 11a: Nederlands-Indië (vervolg)," Moesson, 1 December 1984.

115 AvL, "Het Koninkrijk der Nederlanden in De Tweede Weredoorlog 11a: Nederlands-Indië (2e vervolg)," Moesson, 1 February 1985.

116 Lilian Ducelle and Ralph Boekholt, "Process tegen de staat der Nederlanden Inzake deel 11a," Moesson, 1 March 1985.

117 Robinson to J.W. Meyer Ranneft, 18 July 1955 and 21 July 1955, in Robinson, Schrijven met je vuisten, $77-80$ and $81-84$.

118 Ralph Boekholt, "Indische Nederlanders hebben recht op een eerlijk geschiedschrijving," Trouw, 27 December 1989. 
are considered exclusively in terms of war and social welfare" and what their legal case had demanded was "the correction of a conscious one-sided, negative and sometimes grievous official description." 119

A sequel to the case occurred when Moesson attempted to publish Boekholt's account of the legal process. Government publisher the Staatsdrukkerij (Sdu), attempted to legally prevent Moesson from selling the book, because it looked almost exactly like the volumes of De Jong's work. Trouw inaccurately reported that the state wished to forbid the book. ${ }^{120}$ The state objected only to its cover. ${ }^{121}$ A compromise was reached: Boekholt's book would receive an obligatory sticker declaring that this was not a work of De Jong and not a publication of the Sdu. ${ }^{122}$

However, the organized dissent of Indisch people against how they saw themselves represented in 11a was only the beginning of problems for De Jong. The next couple of additions to Volume 11, also dealing with the Dutch East Indies, were published without much criticism. They dealt with the Dutch at war with Japan and the Dutch imprisoned by the Japanese. Here, the old framework of the good Dutch and the bad enemy worked easily. In 1988, De Jong was due to publish the final volume of his great work, with the subtitle Epilogue. It would provide an account of the post-war period in the Netherlands and include the post-war period in the Dutch East Indies. Unlike his earlier television programme De Bezetting, this time he decided to include the war of decolonization.

The trouble started in late 1987. De Jong had shared with his co-readers a "concept text," as it became known, detailing atrocities by Dutch soldiers and using the term "war crimes." It had been shared in confidence, but co-reader Colonel Heshusius leaked De Jong's concept text. De Jong was furious. ${ }^{123}$ He soon found himself embroiled in a polemic about how to (un) remember decolonization.

In the Haarlems Dagblad, Colonel Heshusius admitted that he had leaked the text to a group of radical right-wing ex-military personnel, but countered that he wasn't at all ashamed, because if he could mobilize a broad mass of people, they might force De Jong to change his mind. He could not tolerate De Jong "kicking the military."124 On the other hand, De Volkskrant supported De Jong. Fred Vermeulen gave a positive review of the disputed unpublished

119 Ralph Boekholt, "Blinde vlek voor Indisch verleden," Trouw, 17 August 1991.

120 “Staatsdrukkerij wil boek ‘De Jong en Indië’ verboden zien,” Trouw, 7 March 1992.

121 "Boek over De Jong lijkt te veel op boeken van De Jong," Algemeen Dagblad, 7 March 1992.

122 "Uitgeverijen sluiten compromis over boek over dr. L. de Jong," De Volkskrant, 7 January 1992.

123 "Prof. de Jong woedend over uitlekken tekst," Algemeen Dagblad, 20 November 1987.

124 Jos Heymans, "Loe de Jong geeft militairen een trap na," Haarlems Dagblad, 20 November 1987. 
Chapter 7 of Volume 12. He was convinced that the excesses committed by Dutch soldiers were many. ${ }^{125}$ Nieuwsblad van het Noorden compared the situation with the Hueting controversy and blamed the veterans for causing it, concluding that war crimes remained "a sort of taboo" that, if some had their way, would remain "beyond discussion."

In the NRC Handelsblad, Van Doorn, co-author of Ontsporing van geweld, was critical of De Jong. He accepted that war crimes had taken place, but asked for understanding for the veterans, describing them as a misunderstood group who simply wanted "a dignified place in the history books." He blamed De Jong for maintaining the good-bad framework that he had used when discussing the German occupation of the Netherlands. This did not work when it came to Indonesia because the Dutch-Indonesian conflict had been "infinitely more complicated than what had taken place during World War Two in the Netherlands." De Jong had fallen into the trap of simply replacing the Germans with the Dutch in Indonesia. ${ }^{127}$ In an interview in De Geldlander, Van Doorn added that the French in Algeria and Portuguese in Africa had acted much worse than the Dutch had. ${ }^{128}$

An exchange in the NRC Handelsblad shows how bitter the polemic quickly became. H.L. Zwitzer, of the Institute of Military History and a former member of De Jong's team of advisers, attacked De Jong for not caring about balanced and responsible history, accusing him of making loose accusations. De Jong's analysis of Dutch war crimes, according to Zwitzer, was an attempt to stain all military personnel who served in Indonesia between 1945 and 1950. ${ }^{129}$ Columnist and veteran Henk Hofland replied to Zwitzer, defending the work of De Jong. He reminded his readers of the letter from an officer in De Groene Amsterdammer in 1949, as well as the interview with Hueting in 1969. Accusing Zwitzer and others of using their sense of outrage as a means of intimidation, he asked: "How can it be that we in 1987 , with the aborted chapter by Dr. L. de Jong, have come no further than we were in 1949?"130 Zwitzer replied that "my problems with the historical demi-god of the Netherlands date from years ago, from long before the time that his

125 Fred Vermeulen, "Excessen bij de politionele acties waren veelvoudig," De Volkskrant, 25 November 1987.

126 H. Wuibs, "Onbespreekbaar: de rol van 'onze jongen' in Indie," Nieuwsbladvan het Noorden, 22 January 1988.

127 J.A.A. van Doorn, “Dr. L. de Jong en Nederlands-Indie," NRC Handelsblad, 3 December 1987. 128 R. Brandsma, “De Jong oordeelt te snel," De Gelderlander, 12 December 1987.

129 H.L. Zwitzer, "De Jong parafraseert er op los," NRC Handelsblad, 5 December 1997. 130 H.J.A. Hofland, “Een per abortus afgeslacht hoodstukje," NRC Handelsblad, 9 December 1987. 
Indische volumes were published." ${ }^{131}$ He did not explain why he only now made them public.

Veteran and writer Ben Laurens, in a thoughtful piece in the NRC Handelsblad, reminded readers that most soldiers had been young conscripts, "adolescents in war." He compared their situation to those Dutchmen and women who had been forced labourers in Nazi Germany. He described the lives of these conscripts - two to three years of living in small, autonomous groups in rural areas, in an alien tropical environment while suffering from loneliness, tiredness and bad nutrition, with shoddy old uniforms, scared of an invisible enemy that practised castration, gouging out eyes and cutting out tongues. He wrote: "Many parents would never sleep again if they only knew how their child was butchered." He concluded: "When judging the cruelties committed there by the Dutch, take this into account."132

Two days later, Hofland replied, praising Laurens for not attacking De Jong, but instead painting a sympathetic portrait of the Dutch soldier. However, it was the politicians who sent these young conscripts to war that carry a heavy responsibility. Yet "the discourse around their guilt has not even started."'33

In a period of just over a month, Wilma Nanninga penned four attacks on De Jong. She claimed that De Jong had agreed to meet in December with his critical advisers and she asked Colonel Heshusius for his reaction: "I hope that we can convince Mister De Jong that he needs to bring affairs into balance."134 She related that a number of historians had written to the Minister for Education, calling on the minister to prevent the publication of De Jong's work in its present form. ${ }^{135}$ Keeping up the pressure, she interviewed a veteran, Captain Düster, a former intelligence chief in Batavia, who maintained that no act of cruelty from Dutch soldiers had gone unpunished. ${ }^{136}$ Düster filed a case against De Jong for defamation. ${ }^{137}$ In late December, Nanninga published her fourth piece, a short interview with Ad Ploeg, member of parliament for the Liberal Party and chairman of the Parliamentary Defence

131 H.L. Zwitzer, letter to the editor, NRC Handelsblad, 15 December 1987.

132 Ben Laurens, "Wat zijn wreedheden en excessen als het gaat om lijfsbehoud," NRC Handelsblad, 4 January 1988.

133 H.J.A. Hofland, "Het Verleden als tegenstander," NRC Handelsblad, 6 January 1988. 134 Wilma Nanninga, “'Excessen niet te vergelijken met Duitse en Japanse," De Telegraaf, 20 November 1987.

135 Wilma Nanninga, "Historici kraken werk Loe de Jong," De Telegraaf, 2 December 1987.

136 Wilma Nanninga and Menzo Willems, "Kapitein Duster nodigt historicus De Jong uit bewijzen te komen inzien: 'Niet een wrede militair ongestraft gebleven,'” De Telegraaf, 12 December 1987. 137 “Aanklacht tegen De Jong," Nieuwsbladvan het Noorden, 11 December 1987. 
Committee, and the only member of parliament who was an Indies veteran. Ploeg revealed he had had a "solid discussion" with Minister of Education Deetman and that he was doing everything possible "to prevent historical injustice from occurring," concluding: "I cannot permit this to happen in an official history, paid for by the state." Ploeg argued that De Jong was "blinded by his socialism and his anti-colonial lens."

In early December, Jos Hagers published a piece about the funeral of recently deceased Captain Westerling in Amsterdam. In his concept text, De Jong had written that Westerling had committed serious war crimes. Hagers reported that the funeral had gathered over 800 veterans and had developed into "a mass demonstration against the history writing of Dr. Lou [sic] de Jong." ${ }^{139}$ The following day Hagers wrote that the vice chairman of an organization representing Dutch World War Two resistance groups was also calling on the Minister for Education to intervene in order to prevent veterans and victims of war from suffering needless pain through inaccurate history writing. ${ }^{140}$

The following month, the court rejected Düster's case against De Jong. ${ }^{141}$ A few months later, De Jong's final volume was published. He revealed that he now distanced himself from the leaked concept text. The new version, he assured the public, was rewritten because of his discussions with experts. ${ }^{142}$ Remarkably, he include a lengthy criticism of Chapter 7 in an appendix, penned by one of his dissenting co-readers.

On pages 1,011-1,012, which in the concept text had been labelled "War Crimes" but was now labelled "Excesses," he included a long footnote:

In October 1987 I confidentially shared, as usual, a concept for Chapter 7 among about 40 persons, who included a number of experts on the DutchIndonesian conflict, with the request that they supply me with their critical feedback. This section of the chapter was consequently passed on by one of the experts to various organizations, including the press, thereby infringing upon confidentiality. Soon it was circulating across the country in dozens, if not hundreds, of copies. ${ }^{143}$

138 Wilma Nanninga and Menzo Willems, "Ik doe er alles aan een historisch onrecht te voorkomen," De Telegraaf, 3 o December 1987.

139 Jos Hagers, “Begrafenis van Westerling," De Telegraaf, 2 December 1987.

140 Jos Hagers, “Verzet: Deetman moet De Jong corrigeren," De Telegraaf, 3 December 1987.

141 "Geen vervolging van Prof. L. de Jong," De Telegraaf, 24 January 1988.

142 "De Jong paste laatste deel na kritiek aan," Nieuwsblad van het Noorden, 28 April 1988.

143 De Jong, Het Koninkrijk, vol. 12b, 1011-1012. 
He explained that criticism of the concept text from within his group of readers had brought him to the decision to make corrections. These corrections included providing more contextual background to the committing of excesses by Dutch troops; providing arguments against the use of the term "war crimes"; refraining from making a comparison between, on the one hand, German behaviour in the Netherlands and Japanese behaviour in the East Indies and, on the other hand, Dutch behaviour in Indonesia. He expressed his deep sorrow that his work had caused a feeling of hurt among old soldiers. He added that the responsibility for causing this unnecessary hurt was the person who had leaked the document. Finally, he alerted the reader to the fact that he had included a criticism of the volume, written by retired Lieutenant-General F. van der Veen, in an appendix $(1,012)$.

In what followed, he provided the context in which the Dutch had committed atrocities, describing how Indonesian nationalist rebels had slaughtered tens of thousands of their fellow Indonesians in the most horrible ways $(1,013-1,015)$. He described how the Dutch faced the difficult task of deciding how to respond to such awful violence, and that the decision made was to reply with counter-terror $(1,015)$. He then gave numerous examples of counter-terror in action, especially under Westering. Thousands of men, women and children were killed in extrajudicial executions and massacres under Westerling's command (1,017-1,021). De Jong described how military, as well as government, authorities were well informed about Westerling's activities; the Dutch press had published reports on the massacres; the parliament in The Hague had been forced to set up an official inquiry which had resulted in a report and that all of this led to the decision to do nothing more $(1,022-1,026)$. De Jong concluded that government ministers knew exactly what was going on in South Celebes and that "Westerling [...] was nothing more than a tool" $(1,026)$.

De Jong gave an account of other atrocities committed by Dutch troops $(1,026-1,034)$. He quoted General Spoor using the term "war crimes" $(1,029)$. This was followed by an account of the methods used by the Dutch Intelligence and Security Service, which frequently included torturing and killing prisoners $(1,034-1,037)$. Again, he quoted Spoor, who, alarmed by evidence of the widespread use of torture, in a report to the authorities in The Hague, compared the Dutch to the Kenpeitai, the Japanese political police $(1,035)$. Similarly, he quoted a report to the prime minister that compared Dutch methods to those of the Gestapo (1,035).

De Jong's analysis of Dutch military courts martial leaves no doubt that they were inadequate. While soldiers were found guilty of murder, not one senior officer had been prosecuted $(1,045)$. He argued that excesses were 
never a secret, but had been publicized during the conflict in Vrij Nederland, Het Parool and De Groene Amsterdammer and that Frans Goedhart had often raised the issue in parliament $\left(1,05^{2}\right)$. He added, "no one in politics in the Netherlands was unaware that excesses had been committed in the Indies" $(1,053)$. However, this was "forgotten" until the Hueting interview $(1,055)$. De Jong's account of the publication of the Excessennota leaves no doubt that he found it to be insufficient $\left(1,055^{-1,058)}\right.$.

De Jong then discussed the use of the term "war crimes." Admitting that the term does not exist under Dutch law, he argued that this form of legalism was a weak argument. He suggested that we should free ourselves from the fear that causes us to avoid the use of the term altogether. He recommended historians should focus on where the primary responsibility lay, namely, at the highest level of political authority $(1,060)$.

Although De Jong maintained that the changes he had made were the result of discussions with experts, historian Jan Bank disagreed. Bank claimed that De Jong had compromised due to pressure from the "Colonial-military lobby." Bank could not hide his disappointment: "In the good tradition of the Indische administration, a group of Indische military managed to shut De Jong's mouth by means of appeals to the judge and minister, through personal threats and through the breaking of confidentiality." He concluded that De Jong was a victim "of a verbal police action." 144 The Utrechts Nieuwsblad included two articles, both focusing on the controversy. The first reported on the press conference preceding the book launch, quoting De Jong, that Chapter 7 was "only a provisional attempt to draw up an outline of the conflict." $" 145$ The second article gave the reaction of Colonel Heshusius. He still maintained that Chapter 7 was "insufficient because you feel De Jong's personal resentment." ${ }^{146}$

Many regional and national newspapers celebrated the appearance of De Jong's final volume as a major national event and hardly mentioned the controversy. There were exceptions. The Nieuwsblad van het Noorden focused on Chapter 7 and gave a positive summary of De Jong's views regarding the decolonization. ${ }^{147}$ The newspaper also carried a sympathetic interview

144 Jan Bank, "Koloniaal-militaire lobby brengt De Jong enigzins uit zijn evenwicht," De Volkskrant, 28 April 1988.

145 "Stuk over Indië in boek De Jong heeft 'voorlopig karakter," Utrechts Nieuwsblad, 28 April 1988. 146 “Oud-Knil-officier Hoofdstuk over oorlogsmisdrijven nog onvoldoende," Utrechts Nieuwsblad, 28 April 1988.

147 "Nationaal besef tegen Duitsers en Indië," Nieuwsblad van het Noorden, 28 April 1988. Peter van der Vusse, "Dr. L. de Jong is klaar: 'Ik ben blij dat het werk er op zit," Nieuwsblad van het Noorden, 28 April 1988. 
with De Jong, as he looked back at the work that he had started in 1955, but without mentioning the recent controversy. Het Vrije Volk was outspoken in its support for De Jong. Maandag's full-page review focused exclusively on Chapter 7 and reprinted De Jong's footnote about the changes he had made. Maandag concluded that "war crimes" accurately described some of the actions of the Dutch during decolonization. ${ }^{148}$

By admitting that he felt the term "war crimes" to be inappropriate and the comparison of Dutch behaviour with German and Japanese beyond the pale, De Jong paradoxically forefronted the issue of war crimes. He refrained from referring to Dutch actions as being "war crimes" and he never compared the Dutch with the Germans or Japanese, but he did allow others to do so, quoting no less a historical actor than the commander-in-chief, General Spoor. Perhaps De Jong's greatest stroke of genius was allowing one of his critics the space to present his case in the appendix. This seemed a humble gesture. However, Frans van der Veen's argument already seemed weak in 1988. From the vantage point of the twenty-first century, it is embarrassing. Van der Veen's main point was that De Jong could not use the term "war crime" because the legal concept of Dutch war crimes was non-existent. ${ }^{149}$ This spurious, legalistic argument holds no water; historiography does not depend on legal definitions. It would mean that historians must refrain from terms such as "Armenian genocide," because the term "genocide" was not recognized under Ottoman law. Even historian Herman Bussemaker, no fan of De Jong, was forced to admit that Van der Veen's argument "misses the moral aspect of the excesses, or war crimes." ${ }^{150}$ Likewise, Oostindie argues that the Fourth Geneva Convention on war crimes may not be applicable to Dutch actions from a judicial point of view, yet for the historian today it offers a "sharp analytical framework."151

Van der Veen argued that it was only in South Celebes that the Netherlands used systematic counter-terror tactics. ${ }^{152}$ Admitting that Westerling's troops carried out 1,500 extrajudicial executions, he concluded that this was the only manner to protect the civilian population. ${ }^{153}$ This is an example of trying to diminish the importance of Dutch killing, but it is now also out of

148 Ben Maandag, “De Waarheid over Indonesië: Term ‘oorlogsmisdaden' is niet te vermijden,” Het Vrije Volk, 28 April 1988.

149 Frans van der Veen, "Het optreden van de Nederlandse en de Republikeinse strijdkrachten," Appendix 2, in De Jong, Het Koninkrijk, vol. 12b, 1,135-1,137.

150 Bussemaker, Indisch verdriet, 171-172.

151 Oostindie, Soldaat, 28.

152 Van der Veen, "Het optreden," 1,140.

153 Ibid., 1,146. 
date. In September 2011, a Dutch court found the Dutch state guilty of killing hundreds of civilians in Rawagede, Java, in 1947. ${ }^{154}$ This makes the attitude of De Jong's biographer Bodewijn Smits all the more remarkable. He agreed with De Jong's critics, claiming that the "weak spot" in De Jong's argument was that the situation in the former colony was "much too complicated" when compared with the German occupation. ${ }^{155}$ Perhaps, but the courts have judged that war crimes were committed, vindicating De Jong's concept text. Gouda commented on the De Jong controversy, "the proverbial cat had escaped from the bag., ${ }^{156}$

By the late 1980s, a number of forces contested the collective memory of decolonization. The Indisch community awaited a vindication of their identity, which could come through a historical narrative constructed by the historical guild. A generation of postmemory authors had constructed postcolonial representations that problematized the phenomena of unremembering. A second generation of Moluccan activists had problematized their unremembered role in decolonization. A significant number of citizens, nudged out of unremembering, felt the history of decolonization to be something shameful, suspecting that the Dutch had failed to investigate the unsavoury part of their history. Due to inertia within the historical guild, they turned to television, radio and newspapers to express their views. Military veterans felt their experience had not been recognized. The Loe de Jong controversy stirred them out of their silence.

\section{Bibliography}

Bank, Jan. Katholieken en de Indonesische Revolutie. Barn: Ambo, 1983.

Baudet, Henri and Cees Fasseur. "Koloniale bedrijvigheid." In De economische geschiedenis van Nederland, edited by J.H. van Stuijvenberg, 309-350. Groningen: Wolters-Noordhoff, 1979.

Baudet, H. and Meindert Fennema. Het Nederlands belang bij Indië. Utrecht/ Antwerp: Het Spectrum, 1983.

Bijkerk, J.C. De Laatste Landvoogd: Van Mook en het einde van Nederlandse invloed in Indië. Alphen aan den Rijn: A.W. Sijthoff, 1982.

154 The verdict of the judge 14-09-1011, ECLI:NL:RBSGR:2011:BS8793, Civil Court, The Haag, http://uitspraken.rechtspraak.nl/inziendocument?id=ECLI:NL:RBSGR:2011:BS8793, accessed 17 July 2019 .

155 Smits, Loe de Jong, 753-754.

156 Gouda, Dutch Culture Overseas, 30-32. 
Bloch, Marc. The Historian's Craft. Translated by Peter Putnam. New York: Vintage Books, 1953 .

Bogaerts, Els and Remco Raben. "Beyond Empire and Nation." In Beyond Empire and Nation: Decolonizing Societies in Africa and Asia, 1930s-1970s, edited by Els Bogaerts and Remco Raben, 7-21. Leiden: KITLV Press, 2012.

Bourdieu, Pierre and Jean-Claude Passeron. Reproduction in Education, Society and Culture. Translated by Richard Nice. London: Sage publications, 1990.

Brante, Thomas. "Sociological Approaches to the Professions." Acta Sociologica 31, no. 2 (1988): 119-142.

Bussemaker, Herman. Indisch verdriet: Strijd om erkenning. Amsterdam: Boom, 2014. Cooper, Frederick. Colonialism in Question: Theory, Knowledge, History. Berkeley, Los Angeles and London: University of California Press, 2005.

Cote, Joost. "Strangers in the House: Dutch Historiography and Anglophone Trespassers." Review of Indonesian and Malaysian Affairs 3, no. 1 (2009): 75-94.

Cribb, Robert. "Circles of Esteem, Standard Works, and Euphoric Couplets." Critical Asian Studies 37, no. 2 (2005): 289-304.

Fasseur, Cees. Dubbelspoor: Herinneringen. Amsterdam: Balans, 2016.

Fasseur, Cees. Eigen meester, niemands knecht: Het leven van Pieter Sjoerds Gerbrandy, Minister-president van Nederland in de Tweede Wereldoorlog. Amsterdam: Balans, 2014.

Fish, Stanley. “One More Time.” In Postmodern Sophistry: Stanley Fish and the Critical Enterprise, edited by Gary A. Olson and Lynn Worsham, 265-298. Albany: State University of New York Press, 2004.

Foray, Jennifer L. "Comparatively Exceptional: The Paradoxes of Twentieth-Century Dutch Imperialism and Decolonization." The Dutch Empire between Ideas and Practise, 160o-200o, edited by René Koekkoek, Anne-Isabella Richard and Arthur Weststeijn, 89-108. London: Palgrave Macmillan, 2019.

Gase, Ronald. Beel in Batavia: Van contact tot conflict - Verwikkelingen rond de Indonesische kwestie in 1948. Baarn: Anthos/In den Toren, 1986.

Gouda, Frances. Dutch Culture Overseas: Colonial Practice in the Netherlands Indies 1900-1942. Amsterdam: Amsterdam University Press, 1995.

Heffernan, Margaret. Wilful Blindness: Why We Ignore the Obvious at Our Peril. London: Simon and Schuster, 2012.

IJzereef, Willem. "De Zuid-Celebes affaire en de Nederlandse Pers 1946-1982." Groniek 8 o (1982): 49-54.

IJzereef, Willem. De Zuid-Celebes affaire: Kapitein Westerling en de standrechtelijke executies. Dieren: De Bataafse Leeuw, 1984.

Jaquet, Louis G.M. Aflossing van de Wacht: Bestuurlijke en politieke ervaringen in de nadagen van Nederlandsch-Indië. Rotterdam: A.D. Donker, 1978. 
Jong, Loe de. Het Koninkrijk der Nederlanden in de Tweede Wereldoorlog. Vol. 11a. Leiden: Martinus Nijhoff, 1985.

Jong, Loe de. Het Koninkrijk der Nederlanden in de Tweede Wereldoorlog. Vol. 12b. Leiden: Martinus Nijhoff, 1988.

Jonkman, Jan A. Nederland en Indonesië, beide vrij; Gezien vanuit het Nederlands Parlement. Assen/Amsterdam: Van Gorcum, 1977.

Kousbroek, Rudy. Het Oostindisch Kampsyndroom. Amsterdam: Olympus, 2005.

Kuitenbrouwer, Maarten. Dutch Scholarship in the Age of Empire and Beyond: KITLV - The Royal Netherlands Institute of Southeast Asian and Caribbean Studies, 1851-2011. Leiden and Boston: Brill, 2014.

Lijphart, Arend. "Political Institutions, Divided Societies, and Constitutional Democracy." In Passion, Craft, and Method in Comparative Politics, edited by Gerardo L. Munck and Richard Snyder, 237-244. Baltimore: Johns Hopkins University Press, 2007.

Maas, Peter F. Indië Verloren, Rampspoed Geboren. Amsterdam: De Bataafsche Leeuw, 1983.

Mink, Louis O. “The Theory of Practise: Hexter's Historiography.” In After the Reformation: Essays in Honor ofJ.H. Hexter, edited by Barbara C. Malament, 3-24. Manchester: Manchester University Press, 1980.

Moor, Jaap A. de. "Van vrije jongen tot ratu adil: De memoires van kapitein Raymond Westerling." Indische Letteren 8, no. 1 (1993): 171-179.

Oostindie, Gert. Soldaat in Indonesï 1945-1950: Getuigenissen van een oorlog aan de verkeerde kant van de geschiedenis. Amsterdam: Prometheus, 2015.

Oostindie, Gert, Irene Hoogenboom and Jonathan Verwey. "The Decolonization War in Indonesia, 1945-1949: War Crimes in Dutch Veteran's Egodocuments.” War in History 25, no. 2 (2018): 254-276.

Poeze, Harry A. Tan Malaka: Strijder voor Indonesië's vrijheid - levensloop van 1897 tot 1945. The Hague: H.L. Smits, 1976.

Poeze, Harry A. Verguisd en Vergeten: Tan Malaka, de linkse beweging en de Indonesische Revolutie, 1945-1949. 3 vols. Leiden: KITLV Uigeverij, 2007.

Raben, Remco. “Hoe wordt men vrij? De lange dekolonisatie van Indonesië.” In: Van Indië tot Indonesië, edited by Els Bogaerts and Remco Raben, 13-29. Amsterdam: Boom, 2007.

Reybrouck, David van. Revolusi: Indonesië en het onstaan van de modern wereld. Amsterdam: De Bezige Bij, 2020.

Robinson, Tjalie. Schrijven met je vuisten: Brieven van Tjalie Robinson, edited by Wim Willems, 81-84. Amsterdam: Prometheus, 2009.

Said, Edward W. Covering Islam: How the Media and the Experts Determine How We See the Rest of the World. London: Vintage, 1997 [1981]. 
Said, Edward W. "Europe and its Others: An Arab perspective." In States of Mind: Dialogues with Contemporary Thinkers, edited by Richard Kearney, 39-47. New York: New York University Press, 1995.

Said, Edward W. "Opponents, Audiences, Constituencies, and Community." Critical Inquiry 9, no. 1 (1982): 1-26.

Said, Edward W. Orientalism. London: Penguin Books, 2003 [1978].

Schermerhorn, Wim. Het dagboek van Schermerhorn, 2 vols, edited by Cornelis Smit. Utrecht: Nederlands Historisch Genootschap, 1970.

Schmidt, Benjamin. "Dikes and Dunes: On Dutch History and Dutchness." BMGN - Low Countries Historical Review 133, no. 1 (2018): 82-99.

Schulte Nordholt, Henk. "Locating Southeast Asia: Postcolonial Paradigms and Predicaments." In Asia in Europe: Europeans in Asia, edited by Srilata Ravi, Beng-Lam Goh and Marrio Rutten, 36-56. Singapore: ISEAS Publications, 2004. Smit, Cornelis. De Dekolonisatie van Indonesië. Groningen: H.D. Tjeenk Willink, 1976. Smits, Boudewijn. Loe de Jong, 1914-2005: Historicus met een missie. Amsterdam: Boom, 2014.

Trouillot, Michel-Rolph. Silencing the Past: Power and the Production of History. Boston: Beacon Press, 1995.

Venner, Dominique. Westerling: De eenling. Amsterdam: Teleboek, 1982.

Wesseling, Henk L. Van Toen en Nu: Opinies en observaties over politiek, geschedenis en cultuur. Amsterdam: Prometheus-Bart Bakker, 2014. 



\title{
$7 \quad$ Remembering the War
}

\begin{abstract}
Works by veterans during the late 1980 s and 1990s illustrated the liminality of veterans' experiences. Their unremembered narratives, ignored by historians, had failed to be integrated into the national collective memory. Oeroeg (1983), the anti-colonial film directed by Hans Hylkema, loosely based on Hella Haasse's novel, provided a restaging on screen similar to Hollywood's Vietnam films. A number of controversies, including the Boomsma affair, the Poncke Princen affair and the queen's 1995 visit to Indonesia, kept the contested nature of collective memory prominently in the news throughout the mid-1990s. Television documentaries highlighted Dutch war crimes, including the massacre of Rawagede, while historians provided solidly researched accounts of the diplomatic side of the conflict as well as the business of running a war.
\end{abstract}

Keywords: liminality, decolonization, Dutch war crimes, Boomsma affair, Poncke Princen affair, collective memory

At a commemoration in 2016, marking 70 years since sending conscripts to fight a colonial war against Indonesian nationalists, Dutch Minister for Defence Jeanine Hennis-Plasschaert said, "there is absolutely no point in walking away from the past. [...] [T] he past will always occupy us." She then said to the elderly veterans: "[Y] our commitment towards gaining recognition and appreciation laid the foundations for the present-day veteran policy." She added: "We commemorate so that we do not forget."

We notice three things from this excerpt. Firstly, there is continuity - three decades after the Loe de Jong controversy, decolonization is still current. Secondly, there is change - it would seem that the age of unremembering

1 "Toespraak van minister Hennis-Plasschaert bij de herdenking bij het National Indiemonument 1945-1962 op 3 september 2016 te Roermond," https://www.nim-roermond.nl/ toespraken/hennis2016.html, accessed 25 February 2021.

Doolan, P.M.M., Collective Memory and the Dutch East Indies. Unremembering Decolonization. Amsterdam: Amsterdam University Press 2021 DOI: $10.5117 / 9789463728744 \_C H o 7$ 
is over. Thirdly, the veterans are seemingly appreciated and remembered. The foundations for these changes did not emerge from work within the historical guild, but from the veterans. Provoked by the Loe de Jong controversy, veterans organized, became more vocal and began to write their own histories, outside the hallowed halls of academia.

\section{Ben Laurens: A Soldier Novelist}

According to Indo author Joop van den Berg, the publication in 1986 of the novel Het Peleton (The platoon) by Ben Laurens and the memoir De heren worden bedankt (The gentlemen will be thanked) by Anton P. de Graaff constituted a new genre that, for the first time, confronted the core issue, "a merciless war between two equal parties [...] with cruelties inflicted back and forth."

We have seen Ben Laurens involved in a polemic with Henk Hofland in the pages of the NRC Handelsblad in 1988. In June 1985, Laurens had taken early retirement from his teaching career. He announced that, now that he had the time, his intention was to write about his experiences as a conscript stationed on Java during 1948-1950. "That period has been long buried in silence," he commented. ${ }^{3}$ Two works of fiction duly appeared - a novel, Het Peloton in 1986, and a collection of stories De Vreet Patrouille (The dispatched patrol) in 1987 .

Het Peloton, begins with a preface that lays out the intention of the author. Firstly, Laurens wishes to provoke all those outfitted with a "corrective memory," pointing out that at the time of the conflict, with the sole exception of the Dutch Communist Party, all Dutch political parties and the overwhelming majority of the population fully supported the war against Indonesian independence. ${ }^{4}$ In other words, he intended to undo decades of unremembering. Secondly, his purpose is to eradicate the myth that the war consisted of two "police actions," with nothing much happening in between or after. Laurens informs the reader that the total number of fatal causalities among the Dutch during the first and second police actions were 127 and 71, respectively. The total number of dead, however, was 2,589 (Peloton, 7-8).

There is a great amount of brutality in both books, sometimes perpetrated by the Indonesian nationalists, but especially by Dutch soldiers. We learn

2 Joop van den Berg, “Boeken over Indie raken eindelijk de kern,” Trouw, 20 August 1988.

3 “Mijn boek ontstond door tijdnood in de klas," Het Vrije Volk, 16 June 1985.

4 Laurens, Het Peloton, 7. 
that the average Dutch soldier felt a close connection with the Indonesian population, but this did not prevent him from carrying out merciless actions (Peloton, 184). After a soldier is abducted and tortured to death, the Dutch in their anger, destroy everything they come across, including livestock (Peloton, 193). After brutal interrogation of two prisoners, they decapitate both, having forced them to dig their own graves (Peloton, 196-199). They torture prisoners by means of electric shocks, then kill them. ${ }^{5}$ Newly arrived soldiers receive the advice that if they ever injure a civilian, it was better to finish them off, because "the dead can't complain" (Vreet, 79).

Soldiers routinely have sex with women, including prostitutes (Vreet, 68; 98-99). Children are born after dalliances with local women (Vreet, 46). The commander of the platoon complains about numerous diseases that his soldiers suffer from: “About VD he wouldn't even start, or he would still be sitting here tomorrow morning" (Vreet, 30). Soldiers swap tall stories about the cruel treatments for venereal disease (Vreet, 159-160).

One might ask, how can Laurens get away with these sort of accusations while Loe De Jong could not? However, Laurens' work places Dutch brutality against a background in which the soldiers are lonely, terrified and betrayed by their government. As his publisher argued, Laurens described incidents that were unacceptable, but placed them "in the right context." ${ }^{6}$ The soldiers' barracks lacks proper electrical lighting (Vreet, 12-13). They lack radios, walkie-talkies and even carrier pigeons (Peloton, 36; Vreet, 14-17). Their guns are shoddy and easily jam (Peloton, 141-142). Transportation vehicles are few $\left(\right.$ Vreet, $\left.5^{2}\right)$. Soldiers suffer from a lack of basic medical equipment (Peloton, 173-175).

The Dutch public betrayed the soldiers at a time of war and continued to do so: "[C]ivilians of their beloved Fatherland promptly forgot the sons that they had sent here and who had been broken" (Peloton, 178). Laurens comments on the Dutch public of the 1980 os when he has the narrator predict that sometime in the future there will be a generation that, when hearing of the victims among the military, will dismiss this with the judgement that they had been fighting for the wrong side (Peloton, 178-179). While for Zwaan, Schilt and Varenne the war had been brutal, for Laurens what made the war unbearable was the betrayal. His books form a double j'accuse against, not simply the military authorities or the government leadership, but the Dutch public and historians, who from the 1940 s until the $1980 \mathrm{os}$ continue to unremember. 
Laurens offered representations of the conditions that the soldiers worked in. Unable to differentiate between friend and foe, living among rats and vermin, always at risk of falling prey to disease or to the enemy, undersupplied and betrayed by their government and seemingly forgotten by their country, they gambled their lives for nothing. We are reminded of his words: "When judging the cruelties committed there by the Dutch, take this into account."7 Remembering is constructed in the social environment of the present. These books were written with an act of remembering turned towards Laurens' experiences during the 1940 s but are rooted in the decolonization discourse of the late 1980s.

The first review of Het Peloton contained a double error. The reviewer claimed that Laurens' novel was the first to describe the "police actions." Firstly, the novel is set during the period of guerrilla warfare that followed the last so-called "police action." Secondly, the reviewer was unaware of the previous novels that had been penned by Indonesia veterans. ${ }^{8}$ Laurens was quoted as complaining that Dutch people have more sympathy for American Vietnam veterans than the Dutch Indonesia veterans. No television maker has ever found it worthwhile to make a documentary about the Indonesia veterans or to cover their annual reunions, he argued. The entire period was "repressed." Joop van den Berg compared Het Peloton to Norman Mailer's The Naked and the Dead, claiming that it successfully evoked how "a small handful of men, with extremely bad supplies, had to fight against an all present enemy [...] in a war of nerves. ${ }^{\prime 0}$ He praised De Vreet Patrouille for its sharp evocation of the bloodiness and cruelty of war. ${ }^{11}$ Historian Joop de Jong argued that Het Peloton provided an important corrective to the accepted image of the war, reminding readers that the Netherlands, "with massive support from parliament and public opinion," had sent young conscripts to fight in a war that they did not understand..$^{12}$ I have been unable to find any reviews attacking Laurens for exposing the cruelties that Dutch soldiers inflicted upon the enemy. Clearly, it made a difference that he was a veteran himself. That Laurens' work was received positively by

7 Ben Laurens, "Wat zijn wreedheden en excessen als het gaat om lijfsbehoud," NRC Handelsblad, 4 January 1988.

8 Tjitte de Vries, "Eerste Nederlandse roman over politionele acties," Het Vrije Volk, 15 November 1986.

9 Ibid.

10 Joop van den Berg, "Te zwaar aangezet oorlogsverslag," Trouw, 29 January 1987.

11 Joop van den Berg, "Boeken," Trouw, 15 February 1988.

12 Joop de Jong, "Hollandse soldaten in Indië kenden een doel - overleven," De Volkskrant, 25 April 1987. 
his former comrades can be concluded by the fact that, during the biggest ever reunion of Indonesia veterans, he was kept busy signing copies of both books for his former comrades. ${ }^{13}$

Yet, the Dutch public seemed uninterested. In 1990, Het Peloton received a second printing. However, both books sank into oblivion. In 2015, Laurens was overlooked when a research team in Leiden spent three years gathering and analysing a "complete" collection of veteran's published egodocuments - diaries, memoirs, stories and novels. ${ }^{14}$ The team published a "complete" online bibliography of known works. It still lacks the name Laurens. ${ }^{15}$

\section{Anton P. de Graaff and The Way Back}

In 1986, Anton P. de Graaff was middle-aged, with a career in international business. Four decades earlier, he had spent eight weeks fighting as a conscripted soldier in the Dutch East Indies. Between 1986 and his death in 2008, he published eighteen books about the colonial war, was knighted and acclaimed as the most influential spokesperson of the East Indies veterans. ${ }^{16}$ Unknown in 1986, five years later he met members of the royal family. ${ }^{17}$ Generals in the Indonesian army and ministers in the Indonesian government became readers of his early books. Most significantly, De Graaff's goal of gaining some recognition for the plight of the East Indies veterans was achieved. ${ }^{18}$

In 1988, the Dutch authorities unveiled the monument to the veterans of the decolonization conflict, the National East Indies Monument, 1945-1962, in Roermond. De Graaff complained about how few members of the royal family or ministers of government paid their respects at the new monument. ${ }^{19}$ Shortly after, Prime Minister Wim Kok began regularly attending the annual commemoration. ${ }^{20}$ In 2020, Prime Minister Mark Rutte gave

13 Huib Goudriaan, “Fantastisch' weerzien voor vergeten leger," Trouw, 19 October 1987.

14 Oostindie, Soldaat, 319-320.

15 Gepubliceerde egodocumenten van Nederlandse militairen in/veteranen uit de oorlog in Indonesië, 1945-1950 (26 April 2017), https://www.kitlv.nl/wp-content/uploads/2017/o4/ Lijst-met-gepubliceerde-egodocumenten-Indi\%C3\%AB-veteranen-26-april-2017.pdf, accessed 4 January 2018.

16 Charles Sanders, "Indiëveteraan/auteur De Graaff overladen," De Telegraaf, 7 January 2008.

17 "Prins Bernhard krijgt boek verbroederingsreis," Nederlands Dagblad, 20 June 1991.

18 Noel van Bermmel, "Pleitzorger voor de gewone Indië-veteraan," De Volkskrant, 8 January 2008.

19 De Graaff, Zeg, 15 .

20 Huib Goudriaan, "Veteranen bevochten erkenning: Vijftig jaar na Indië-oorlog is Nederland nu zuinig op oude en jonge ex-militairen," Trouw, 26 July 1997. 
the commemoration speech, drawing attention to his personal postmemory experience of the conflict. ${ }^{21}$ Perhaps the best illustration of De Graaff's influence is found in the 2016 speech of Hennis-Plaschaert, with which I started this chapter, where she quoted directly from De Graaff's work. ${ }^{22}$

In 1988, De Graaff did not make his intentions a secret. In an attack on the historical guild, he wrote, "We, old East Indies soldiers, want to gain recognition, that we went to present-day Indonesia by order of the Dutch government and left a part of our youth there. We, old East Indies soldiers, want this to be mentioned in the school textbooks and that history will no longer be silenced." ${ }^{23}$ The subtitle of his first volume is Het Vergeten Leger (The forgotten army) and he repeatedly hammered home the injustice of being unremembered.

Unremembering had begun as the war approached its end. De Graaff describes the situation in 1949: "three lads of 21 years old lie in freshly dug graves and another four are missing in action while in the Bijenkorf [a department store in Amsterdam] a new window display is being readied." ${ }^{24}$ In Amsterdam, "police direct the traffic, a cyclist gets a fine because he didn't stick his hand out, and a housewife complains because milk is one cent dearer. [...] [N]o one pays attention to the list of casualties way down at the bottom right of the front page."25 Though hostilities ended in 1949, thousands of young Dutch soldiers remained stationed in the newly independent Indonesia, while the home front in Holland "starts to become silent. [...] [W]e became the 'defeated' army, now we are THE FORGOTTEN ARMY.". ${ }^{26}$

Unremembering continued when soldiers came home:

The ex-soldiers returned to a society in which there were those who were ashamed of this war and who wanted it to be forgotten. [...] [T] heir own children approach it like this - in ignorance - [and] their father and lots

21 "Toespraak minister-president Mark Rutte bij de Nationale Herdenking 15 augustus 2020 bij het Indisch monument in Den Haag," https:/www.rijksoverheid.nl/documenten/toespraken/2020/o8/15/toespraak-van-minister-president-mark-rutte-bij-de-nationale-herdenking15-augustus-1945, accessed 27 February 2021.

22 "Toespraak van minister Hennis-Plasschaert bij de herdenking bij het Nationaal Indië Monument 1945-1962 op 3 september 2016 te Roermond," https://www.nim-roermond.nl/toespraken/ hennis2016.html, accessed 25 February 2021.

23 De Graaff, De weg, 7-8.

24 De Graaff, De heren, 4.

25 Ibid., 43.

26 Ibid., 156. 
of other veterans didn't speak, and still don't speak about it with their wives." $^{27}$

A soldier who wanted to talk felt like, "a stranger in his own family." ${ }^{28}$ Decades later De Graaff visited a Dutch war cemetery in Indonesia: "Graves of lads that no one in Holland ever thinks about anymore." ${ }^{29}$ He calls for historians to do their job: "It is not acceptable that lads of 20-21 years of age lie there, that in total more than 5,00o lads remain buried there and that this is not mentioned in the school textbooks." ${ }^{30}$ Recent events, not least the Loe de Jong controversy, had provoked discussion about Dutch military actions in the former colony, but, according to De Graaff, "we are still a 'forgotten army,' because as long as our history is kept away from children in schools, our history will die together with us." ${ }^{1}$

De Graaff presented a picture of a futile war without redeemable qualities, a war in which the lives of the ordinary soldier, in the eyes of the Dutch authorities, were held to be cheap. ${ }^{32}$ He admitted that they had arrived with the notion that they would restore order and peace, but were reduced to fighting for their lives, while "what the gentlemen in The Hague decide leaves us cold." 33 He told of four of his comrades taken prisoner by the enemy and held for three and a half months. The Dutch military authorities deducted their pay for their time spent in captivity. ${ }^{34}$

De Graaff's battalion spent 75 weeks in Indonesia, though only the first eight were spent fighting. After eight weeks, the ceasefire kicked in. In other words, his brigade of badly trained conscripts were shipped to the front, at a time when the military and political authorities in The Hague were fully aware that it was a lost cause. Van Doorn, co-author of Ontsporing van geweld, asked in the foreword to De Graaff's first book, "Why did they sacrifice human lives for a cause that was being politically resolved?"35 After visiting the graves of eight of his former comrades in Bandung, all killed at the age of 21, De Graaff reflected: “They shouldn't have been lying

De Graaff, De weg, 24.

De Graaff, Brieven, 13 .

De Graaff, Met de TNI, 166.

De Graaff, De heren, 55 .

Ibid., 74 .

4 Ibid., 88.

35 J.A.A. van Doorn, foreword to De Graaff, De heren, 12. 
there" because by the time they arrived in Indonesia, the war "that must not be called a war, was in fact, already over." ${ }^{36}$

The weeks that they spent fighting were intense and unforgettable. He described a patrol being ambushed. When they recovered the body of their corporal, they found a bullet hole in his groin, his throat slashed open, his left ear and nose cut off. ${ }^{37}$ He described the fear among the inexperienced young men, as hundreds of Indonesian soldiers under Japanese officers surrounded them in the jungle: "I still see the terrified faces around me and hear the despairing voices asking what we should do. Living creatures in mortal fear. Lads like me, who just like me had had no experience of anything and now ran around praying or cursing. ${ }^{n 8}$ This did not necessarily diminish the significance of Dutch military violence; rather, by providing the historical context, it emphasized the gravity of decisions taken in Batavia and The Hague.

Although De Graaff's battalion saw only eight weeks of fighting, what followed the end of hostilities was in some ways even worse. Repatriation took over a year: "Some men [...] lose it. They cannot stand the loneliness, the longing for home, cannot bear the longing for wife or fiancé anymore. [...] Driven crazy, they go into the kampong [village] and come out with a venereal disease." 39 The city of Semarang became a "Wild West" city with the disarmed Dutch becoming victims of "muggings, car theft, and burglaries. ${ }^{30}$

De Graaff gave numerous examples of how veterans still carried the memory of their experience, in the form of physical and mental scars. One returns from the conflict with a major loss of hearing. ${ }^{41}$ One spends 20 years taking drugs in order to fight nightmares, dizziness, depression and fear of the dark (Brieven, 30). Another suffers from stomach infections and gastric haemorrhages (Brieven, 47). Depression forces one into early retirement (Brieven, 45). Another admits that he became a torment to his family (Brieven, 48).

De Graaff is angry that these men received inadequate state support. Indeed, the government cannot even supply the exact number of Dutch fatalities in the war (Brieven, 115). Having undertaken a return journey to Indonesia, De Graaff feels that this is what many veterans need. However, 
most cannot afford to undertake such a journey and the government refuses to pay (Brieven, 8, 13, 30-31, 62). De Graaff argues that psychological scars have passed to the second generation, giving the example of a woman who cannot mourn properly for the father she never met, because he lies in a cemetery in Indonesia. Neither she nor her mother can afford the journey (Brieven, 47).

De Graaff undertook the journey back to Indonesia, together with a small group of comrades, and found it to be healing. They had gone on patrol again to "liberate themselves from the memory that has haunted them for 38 years" (De weg, 10). They returned to the place of their nightmares to discover that returning "was their best form of therapy, [...] a way of coming to terms with their unprocessed memories" (De weg, 107).

Having completed three books that had sold well, De Graaff might have been forgiven for concluding that his work was done. In December 1990, however, De Graaff accepted an invitation from Lt. General Dading Kalbuardi, Inspector General of the Department of Defence in Indonesia, to organize an official visit of veterans to Indonesia. ${ }^{42}$ The visit took place in March 1991. The following month, De Graaff declared the trip to have been "1,0oo per cent successful," having been treated like heads of state, and his traumas had disappeared. Thinking of the war crimes discourse dominating Dutch media, he remarked that Indonesian former freedom fighters regarded the entire decolonization as a "misunderstanding." ${ }^{3}$ A few months later, De Graaff's account of the visit was published.

De Graaff informed the reader: "Returning to Indonesia is the best therapy." ${ }^{\prime 4}$ He returned with other veterans to the scene of a Tentara Nasional Indonesia (TNI, Indonesian National Military) ambush in which three Dutch soldiers had been killed. The veterans include Bartels, who had been captured by the TNI. They met a local villager called Salimin, who turned out to be one of the fighters who had captured Bartels. Salimin asks Bartels to forgive him: "Bartels begins to cry," but soon, "Salimin, his former enemy, and Bartels, walk hand in hand along the railway" (Met de $T N I, 28)$. The photograph on the cover of the book shows the two former enemies walking hand in hand.

The veterans walk the path that in 1949 had been the scene of a fatal ambush. They walk with one of their former enemies who admits how easy it had been to shoot them and then disappear in the jungle. The experience brings healing, De 
Graaff remarking: "This cannot be described! This means the definite end of the trauma" (Met de TNI, 128). Journalist Rinze Brandsma, who had accompanied the group and whose article is included in De Graaff's book, described it as "the final coming to terms with unprocessed memories" (Met de TNI, 168).

Mixed groups of Dutch and TNI veterans travelled together to villages where they once had fought each other. As they eat together and enjoy each other's company, they exchanged name tags in an act of fraternization (Met de TNI, 118-124). In Semarang, the Dutch visited the Dutch war cemetery, together with members of a militant student group that had been their enemy and had killed their comrades who now lay in these graves (Met de TNI, 153). That evening the Indonesian Minister of Defence, and seven generals and three admirals, joined them for an official dinner. De Graaff described the scene: "There is no difference anymore; we all sit there as soldiers and old soldiers" (Met de TNI, 163). More receptions followed at the homes of generals and admirals and the Dutch embassy (Met de TNI, 180-183).

From a historical perspective, the book included three chapters of interest. Brigadier-General Hardijono chronicled the Indonesian military side of the story regarding the conflict in the area of Wonosobo (Met de TNI, 45-83). R. Wahjudi Brotodiredjo wrote a short history of his student resistance organization (Met de TNI, 96-110). One chapter, assembled especially for the Dutch visitors, offered an Indonesian perspective on the first "police action" (Met de TNI, 135-150). No one within the Dutch historical guild had produced an account with such diverse perspectives.

This point was not lost on reviewers. Though Jan Hoffenaar was clearly irritated by De Graaff's name-dropping, he admitted that the three Indonesian chapters "give insight into the organization and tactics of these groups," adding that there had been very little of Indonesian memory literature published in Dutch. ${ }^{45}$ Joop van den Berg noted that it had taken 40 years to gain the first image of the Indonesian soldier. ${ }^{46} \mathrm{~J}$.A. van Hooglander judged that the three chapters made De Graaff's work "unique" as they demonstrated the vision and motivations of the Indonesian freedom fighters and convincingly showed that Dutch war making had been futile. ${ }^{47}$

In his further work, De Graaff continued to complicate the one-dimensional Dutch perspective on the conflict. His book Notities van een soldaat (Notes from a soldier) focused on the Dutch volunteer soldier, Adrian van der Heiden, while Zeg, Hollands soldaat... (Hey, Dutch soldier...) from 1995, was

45 Jan Hoffenaar, “Veteranen," NRC Handelsblad, 31 August 1991.

46 Joop van den Berg, "Omzien met steeds minder wrok," Trouw, 3 August 1991.

47 J.A. van Hollander, “met de TNI op stap," Nederlands Dagblad, 26 June 1991. 
based on letters written by a young conscripted Dutch soldier. This volume opened with a full-page photograph of the Indonesian, Trisunu, who had accompanied the group during their reconciliation trip of 1991. The caption under the photograph read "freedom fighter Trisunu." 48

His next volume, Merdeka, from 1995, offered a postcolonial perspective on the conflict, using multiple perspectives. ${ }^{49}$ The title alone gives us pause. "Merdeka" ("Freedom") was the slogan that Indonesian nationalists shouted and painted on walls in 1945. De Graaff explained: "Freedom, which was hard fought, but eventually led to a great Indonesia, which this year remembers that independence was proclaimed 50 years ago. ${ }^{50}$ The cover of the book showed a photograph of Indonesian soldiers and the first page a photograph of a small group of "freedom fighters," two of whom are named (Merdeka, 4). The book contained eight photographs showing people - two photographs of Dutch soldiers, one of Indonesian women and five of Indonesian freedom fighters. The book ended with an explanation of the symbol for the Republic of Indonesia, the Garuda (Merdeka, 172-173). All of this reflected a sympathetic interest in the former enemy.

Merdeka is De Graaff's first venture into what seems to be historical fiction, based on a manuscript by the "white Indonesian," Pim Coulson (Merdeka, 7). The book has a number of main characters, Indonesian, Indisch and Dutch. One of the Indonesians, Hamdani, is a thug who terrorizes his own people (Merdeka, 66-70, 76-77, 135-137). Some Dutch soldiers spend their free time with prostitutes (Merdeka, 39-50). Two soldiers of the KNIL (Royal Netherlands East Indies Army) sell weapons to the enemy (Merdeka, 51-55). Their behaviour contrasts sharply with the Indonesian freedom fighter Lieutenant Marsoedi, a hero of the book. Marsoedi leads an attack on a Dutch position. The attack is described from an Indonesian point of view. Marsoedi is portrayed as a leader who holds the respect of soldiers and who has a strong sense of justice (Merdeka, 13-21). He is captured by the Dutch and earns the admiration of his jailers and lawyer. The latter reflects: "a freedom fighter, but how obscene it was that a state of war didn't exist. There were only police actions of a lawful authority" (Merdeka, 113). Facing execution, Marsoedi meets his end with dignity (Merdeka, 149-156). This contrasts with the behaviour of a member of the KNIL, jailed for illegally selling weapons. Terrified, he hangs himself in his cell (Merdeka, 126).

48 De Graaff, Zeg, 6.

49 De Graaff's Merdeka, like the works of Ben Laurens, is not included in Oostindie's bibliography of veterans' published egodocuments.

$5^{0}$ De Graaff, Merdeka, 7 . 
A leading character is an Indonesian tani or peasant. We learn his name, Serin. We discover his thoughts, as well as those of his wife. He is abused by thugs and is then badly beaten by the Dutch (Merdeka, 65-88). Serin is a victim twice over, but we would be mistaken to conclude that De Graaff allows the subaltern no agency. Serin weighs up his options and carries out an action that pleases the Dutch authorities, but avoids reprisal when Merdeka is achieved (Merdeka, 135-140, 144-145). His cautious wisdom ensures his survival. The book ends with him feeling "good and content," back on his patch of land in the village where the flag of the Republic of Indonesia now waves freely (Merdeka, 167).

De Graaff's sympathy for the cause of Indonesian independence deepens his conviction that it was a futile war. This means that he and other young men who were fulfilling their military service were the first victims of the Dutch "historic miscalculations. ${ }^{\prime 1}$ Dutch soldiers were victims, and so it is irritating that Dutch media and Loe de Jong have branded them war criminals. In Merdeka, a Dutch soldier called De Rooie is portrayed as being well intentioned and honest. Like the Indonesian freedom fighter Marsoedi, he is an honest man fulfilling his duty. Like Marsoedi, he is killed, a victim of a futile war brought about by politicians in The Hague. ${ }^{2}$ De Graaff could not resist lecturing the reader. He argued that such a soldier "was the opposite of what some people - let's call them the 'mad bloodsuckers' - now, 50 years later, try to scream about the old East Indies soldiers." ${ }^{33} \mathrm{He}$ dismissed what had been said on television about war crimes: "every old East Indies soldier knows himself if he is guilty or not."54

This is not to say that De Graaff ignored Dutch soldiers behaving badly. He showed that drunkenness was common..$^{55}$ The officer class was particularly given to drunken debauchery. ${ }^{6}$ Dutch soldiers traded tinned good and cigarettes for sex. ${ }^{57}$ With the newly independent Indonesia suffering from shortages and rising prices, Dutch soldiers made a quick profit selling military goods on the black market..$^{8}$ Soldiers gave in to loneliness and turned to prostitutes for relief. ${ }^{59}$ Many contacted venereal diseases. ${ }^{60}$

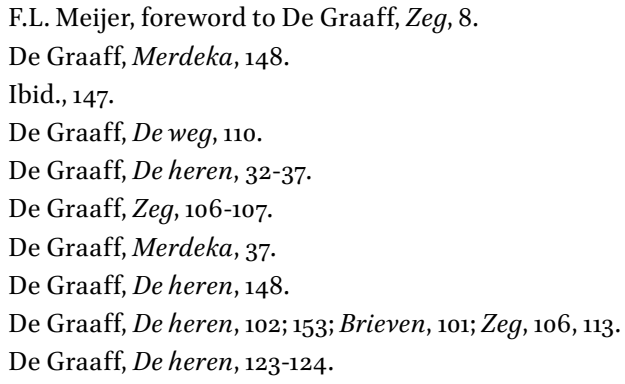


De Graaff supplied notable examples of Dutch violent excesses. Prisoners were beaten. ${ }^{61}$ Intelligence was gained through hard interrogations. ${ }^{62}$ Kampongs were burned. ${ }^{63}$ Wounded enemies were shot dead. ${ }^{64}$ In one passage, soldiers from the KNIL hunt down a TNI group and their Japanese instructor, subject them to hard interrogation, force them to dig their own graves, then shoot them dead. ${ }^{65}$ However, many of these incidents are silently justified through the context. Excesses were committed in response to the killing of Dutch soldiers. The worst excesses were perpetrated by KNIL soldiers, the survivors of brutal Japanese imprisonment.

De Graaff argued that conscripted young Dutch soldiers were victims. It is hard to see a victim as a perpetrator. This is underscored in Zeg, Hollands soldaat..., which closed with pages copied from a manual that had been supplied to soldiers. The manual explained how Dutch soldiers should search a kampong. When searching a house, it is recommended to never shoot in the air, but to shoot directly through the bamboo walls of the house, from above to below. The soldier should then use his bayonet to cut the supporting ropes, causing the walls to collapse. The soldier should then search the house by stabbing with his bayonet anything that might hide a human. General Spoor, the commander-in-chief, issued these instructions to the soldiers. ${ }^{66}$ De Graaff adds the rhetorical question: "Is it crazy, that not hundreds but thousands of old East Indies soldiers are walking around with traumas?" ${ }^{67}$ De Graaff records one veteran: "I was not a war criminal, I was not a user of whores, I was not an alcoholic, I was not a moral degenerate," adding, "Where was Loe de Jong in the period from 1945 to 1950 ?"68

De Graaff reports a conversation between him and other veterans: ${ }^{69}$

De Graaff: The war was completely futile; entirely wrong. [...] Things were done there that are not acceptable. But not by our battalion.

Van Erp: I don't like to hear that we were war criminals. 
Marius: Still, it begins to eat at you. Like rust. If you don't scrape it off, it eats through and destroys you.

De Graaff: No, the best medicine is to return to Indonesia.

This passage reveals interesting points. Firstly, Van Erp's remark indicates how sensitive the veterans had become to the dominant mode of discourse during the late 1980 s. Secondly, Marius' remark is ambiguous. It is not clear if what "begins to eat you" is a sense of guilt, or if it is the accusations, that begins to eat you. I suspect it is the latter. Thirdly, De Graaff's "not by our battalion" is ambiguous. He seems to be saying that war crimes did take place - "but not in our battalion." Finally, there is De Graaff's last remark. The best medicine is to return. The power of the return is twofold. It provides therapy that relieves trauma. It brings one to the realization that the Indonesians themselves are not obsessed by the issue of war crimes. The entire conflict was a "misunderstanding." In a radio interview, De Graaff claimed that he and his former enemies had become brothers - "We don't accuse each other of anything, so would the people in Holland please stop their whining about war crimes."70

The popularity of De Graaff's books among veterans, and the popularity of embarking on a journey back to Indonesia, can be understood if we frame the plight of the veterans within a concept from cultural anthropology, namely, liminality. Arnold van Gennep argued that, implicit in the lives of human beings, are a succession of stages, with beginnings and ends, events like birth, puberty, marriage, parenthood, death, and so on. Each event is accompanied by a rite of passage, the purpose being "to enable the individual to pass from one defined position to another." ${ }^{11}$ Van Gennep's insight was to propose that rites of passage can be subdivided into rites of separation, transition and incorporation. ${ }^{72}$ He called these stages preliminal, liminal and postliminal. Preliminal rites involve "separation from a previous world." Liminal rites are "executed during the transitional stage." Postliminal rites are "ceremonies of incorporation into the new world." 73

This can be applied to conscripted soldiers. They pass through a preliminal stage - leaving home for residence in a barracks, getting a military-style haircut, donning a uniform. This marks them as separated from their

70 This interview was broadcast after his return from Indonesia in 1991 and rebroadcast upon his death in 2008: Omroep Brabant, In memoriam Anton de Graaff, 7 January 2008.

71 Van Gennep, The Rites, 3.

72 Ibid., 11.

73 Ibid., 21. 
previous world. The liminal stage involves life in the army. Here, one lives within a horizon radically different from the norms and values of the regular world, most clearly defined by the fact that soldiers are trained to kill. For the Dutch soldiers in Indonesia, this liminal stage involved becoming violent actors operating out of sight from the home front. An important rite is the postliminal stage, in which the soldier is reincorporated into the civilian world. For the Dutch soldier in Indonesia, reincorporation would have to wait years, until their return to the Netherlands, and would only be partially successful.

The work of British cultural anthropologist Victor Turner focused on the "betwixt and between" stage of liminality, in which liminal entities are "neither here nor there," but living beyond what is customary. ${ }^{74}$ Turner realized that the liminal stage can become permanent. Instead of a threshold, the liminal becomes a way of life. ${ }^{75}$ For instance, certain monastic orders withdraw from the world and transition becomes "a permanent condition."76

Turner argued that those who live in a liminal state "tend to develop an intense comradeship and equalitarianism," what he calls "communitas."77 Communitas is spontaneous and equalitarian. He characterized the relational quality of communitas as "unmediated communication, even communion," ${ }^{78}$ much like what was described in Varenne's work of 1969. Communitas is regarded as dangerous by non-liminal society. ${ }^{79}$

Recent studies indicate that recovery from battlefield experiences depend on the society that the soldier re-enters. ${ }^{80}$ The failure of reincorporation leaves former combatants in a liminal state, susceptible to trauma. Laurens, De Graaff and thousands more, feeling themselves to be members of a forgotten army, had lived for decades, partially, in a liminal state. This is suggested in the title of one of De Graaff's later books, Levenslang op patrouille (Lifelong on patrol). ${ }^{81}$ The failure was one of postliminal reincorporation. Young men, separated from the world they had grown up in, were trained and sent to kill and returned to a society intent on post-war reconstruction. They were reinserted, but not reincorporated, into a society that considered their exploits shameful. This made it impossible to share their experiences with 
their children or their wives. ${ }^{82}$ Veterans found work, built careers, raised families. However, with the historical guild unremembering the conflict, their experiences were never acknowledged, and therefore reincorporation remained incomplete.

As represented in the books of Varenne, Laurens and De Graaff, one of the few certainties in the nightmare of war, was the comradeship or communitas, shared by the soldiers. This feeling was intensified by the antagonism that they felt towards the military and the political leadership. The shared sense of grievance stemmed from being unremembered, and this increased their self-perception of being outsiders, being liminal. Even decades after the war, communitas could be renewed at annual reunions.

Turner and his wife, the anthropologist Edith Turner, saw pilgrimage as an intensification of communitas. ${ }^{83}$ Religious pilgrims seek some sort of initiation, but also desire to find a cure. ${ }^{84}$ Pilgrimages, according to Victor Turner, "are full of symbols and metaphors of death." ${ }^{85}$ Pilgrims are "self-torn from their familiar environment" and may come to see the metaphoric death of the pilgrimage as "a death to the negative alienating aspects of system and structure," which leads to a regaining of "an innocence felt by them to have been lost." 86

Turner could have been describing the phenomena of De Graaff's two pilgrimages to Indonesia. Indeed, De weg terug (The way back) has a double meaning. At a superficial level, it refers to the way back to Indonesia. A deeper reading reveals that it is also a way back to "an innocence felt by them to be lost." After all, De Graaff tells us that the pilgrims to Indonesia had left "a part of our youth there." ${ }^{\prime 87}$ One soldier even finds his former girlfriend, and the pilgrims are relieved to discover she "she hasn't changed in the slightest and still speaks fluent Dutch." ${ }^{88}$ The pilgrimage character of the journey was not lost on reviewers. ${ }^{89}$

Turner tells us that pilgrimages are saturated with metaphors of death. De Graaff's books describe visits to places where killings took place and

82 De Graaff, Brieven, 10-11.

83 Turner and Turner, Image, 34 .

84 Ibid., 13-14.

85 Turner, Blazing, 29.

86 Ibid., 30-32.

87 De Graaff, De weg, 8.

88 Ibid., 91.

89 Joop Morriën, "De heren worden bedankt," De Waarheid, 1 August 1986; Joop Morriën, "Nederlands legerleiding onderschatte de kracht van het Indonesische verzet," De Waarheid, 21 May 1988; Joop de Jong, "Een indringende collage van verbittering en wrok," De Volkskrant, 9 September 1989 . 
to cemeteries where dead comrades rest. He closes his account of the first pilgrimage with a chapter entitled "Terug over de dodenweg" ("Return along the Road of Death"). ${ }^{\circ}$ De Graaff converses with three other pilgrims. They have just returned from re-enacting the fatal patrol along the Road of Death:

De Graaff: I walked in a trance. Like how a fakir lies on a bed of nails. [...] Marius: It was as if we had passed through a peeling machine. Yah, something changed. We were not the same.

De Graaff: [...] What was the most important thing for you, Joep? Joep: That I have been back to the place where Jo Bedaux died. That is the most important part of the entire journey. Then, it brought something out of me. [...] I had lived towards this for 38 years; all those years the East Indies had haunted me. But now that I've been here, I can think about it much more calmly. It has indeed been liberating. ${ }^{11}$

The language reads like an anthropologist's field diary. De Graaff's walked “in a trance" like a fakir, Marius' passed "through a peeling machine," Joep sensed that "it brought something out of me." It sounds initiatory. The remarks, "something changed. We were not the same" and the description that it was "liberating," imply passing through or beyond a threshold, the liminal. The postliminal pilgrimage had succeeded in reincorporating them back into the world. As De Graaffput it: "They began to see everything with new eyes."92

According to De Graaff, this journey to the place associated with death, healed trauma. This was confirmed by the second pilgrimage, undertaken by a larger group of Dutch veterans, accompanied by dozens of Indonesian freedom fighters. Again, they walk the Road of Death. Again, De Graaff confirms that this means the end of traumas. ${ }^{93}$ We learn of the curative qualities of pilgrimage..$^{4}$

The group of veterans possess a sense of comradeship or communitas. This is deepened during the pilgrimages, but it is broadened to include Indonesians, the former enemy. De Graaff repeatedly emphasized that Indonesian leaders joined them. His prose at these times seemed to suffer from exaggeration: "There is no difference anymore. [...] [G]enerals had been freedom fighters then, without rank. We had been military conscripts." But 
now they realized "that we had a connection [...] without rank or class." ${ }^{\text {95 }}$ This irritated some reviewers. Jan de Graaf complained that De Graaff's account suffered from an overuse of drama. ${ }^{96}$ Hoffenaar felt that De Graaff's tone should have been more tempered. ${ }^{97}$ However, De Graaff's emotional prose was his attempt to convey the sense of communitas.

Oostindie makes clear that the number of East Indies veterans who published memoirs before the 1980 s, in fictional or non-fictional format, had been slight. The 1960 s saw a meagre ten publications, while during 1970 s the total was only fourteen. However, the 1980 s and 1990s saw an explosive tenfold increase. ${ }^{8}$ What accounted for so many suddenly putting pen to paper?

De Graaff offered the simplest explanation. He claimed that memories had been suppressed while the veterans had been building careers and raising families. However, entering their 5 os, memories came creeping back into consciousness, "above all the unpleasant memories." ${ }^{99}$ By the mid-198os, many, like Ben Laurens, would have been approaching retirement, allowing for deeper dwelling on the unincorporated memories of their experiences. As Oostindie puts it, there may not have been just a "Hueting effect," but also a "pension effect."100

In Dutch military and psychiatric circles, it was long accepted that old traumas could reappear after many decades. In 1980, post-traumatic stress disorder was recognized as an official psychiatric diagnosis. ${ }^{101}$ The same period saw an "explosion of new organizations of and for war victims," and these were dominated by those who considered themselves victims from the East Indies. ${ }^{102}$ The national Vereeniging Oud Militairen Indiëgangers (Association of East Indies Veterans) was founded in 1985, in order to lobby for the veterans who considered themselves "victims of a lack of recognition." ${ }^{103}$ In 1989, the association participated in the creation of a national "Veterans' Platform," under the chairmanship of Ted Meines, an East Indies veteran himself. ${ }^{104}$ Thus, the works of Laurens and De Graaff appeared against a

95 De Graaff, Met de TNI, 163-165.

96 Jan de Graaf, “De Colombo Tragedie’ en de Gordel van Smaragd," Het Parool, 23 November 1991.

97 Jan Hoffenaar, "Veteranen," NRC Handelsblad, 31 August 1991.

98 Oostindie, Soldaat, 315 .

99 De Graaff, De weg, 13.

100 Oostindie, Soldaat, 315 .

101 Annet Mooij, “De Langste Schaduw," 280.

102 Ibid., 278.

103 Bosma, Terug, 255.

104 Huib Goudriaan, "Veteranen bevochten erkenning: Vijftig jaar na Indië-oorlog is Nederland nu zuinig op oude en jonge ex-militairen," Trouw, 26 July 1997. 
background in which victimhood was increasingly a political football game, the prize being recognition but also better pensions and social welfare. ${ }^{105}$ The increasingly well-organized veterans were becoming a force in the new memory discourse, leading anthropologist Nico Schulte Nordholt to quip that the veterans' lobby was rewriting or erasing history while, what was needed, was "for history itself to be written." 106

True, some books by veterans at this time gave a sanitized view of the conflict. Take, for example, the account by General Spoor's aide-de-camp, R.M. Smulders. What he offered was a nostalgic ode to the late General Spoor. The book includes photos of dead Dutch soldiers, graveyards, and destroyed tea plantations, but no Indonesian fighters are shown. We are told that the Indonesian folk were pleased with the "police actions. ${ }^{107} \mathrm{His}$ account included no references to any actual combat. ${ }^{108}$ Spoor is portrayed as a sober, workaholic intellectual, quoting freely from Shakespeare, Goethe and the French philosophes. ${ }^{109}$ Smulders concluded that war never happens without crimes, torture, rape, horrible wounding and killing, but that the Dutch army "liberated people, fed children, cared for the wounded who, because of us, survived to experience other, happy years." ${ }^{\text {110 }}$

However, the works of Laurens and De Graaff gave a fuller picture of life among Dutch conscripts during the conflict. De Graaff's work, and Merdeka, in particular, provided postcolonial, polyglossia accounts of the war. Nevertheless, historian Joop de Jong condemned De Graaff's works, seeing in them a connecting thread "of bitterness, revenge and a feeling of being victimized on all fronts." ${ }^{\prime \prime 11}$ This caricature ignored two things. Firstly, for over four decades Dutch society, including historians, had unremembered that their government forced tens of thousands of youths to fight a colonial war. Secondly, with some exceptions, the little that was known about the dirty war, was known, thanks to the words of veterans like Sytzen, Hueting, Schilt, Zwaan, Varenne, Hendrix and Van Doorn, Laurens and De Graaff, and not thanks to the works of historians. In 1995, a report about the services offered to veterans concluded that veterans placed the greatest value on the

105 Mooij, “De Langste Schaduw," 280-285.

106 Maurits Schmidt, "Sterke veteranenlobby poetst geschiedenis weg," Het Parool, 27 December 1994.

107 Smulders, Een stem, 65 .

108 Ibid., 69-74.

109 Ibid., 94-98.

110 Ibid., 143.

111 Joop de Jong, "Een indringende collage van verbittering en wrok," De Volkskrant, 9 September 1989 . 
"immaterial advantages of recognition and legitimacy."112 They hankered after "symbolic value."13 Veterans wanted an acknowledgement that they had served their country. The most likely place to receive this would be in the works of historians, but few in the historical guild showed an inclination to provide it.

\section{Oeroeg: The Film}

Steven Lipkin has written that two of the most important functions of historical films are "Provoking public memory and shaping national identity."14 In 1993, the film Oeroeg, directed by Hans Hylkema, premiered. Its popular representation played a significant role in provoking public memory. To some extent, it normalized discussion of Dutch military actions during the decolonization conflict.

In 1992, the Dutch press reported that De Stichting Veteranen Platform (Veterans' Platform Foundation) had written to the Minister of Defence expressing concern that the film would offer a negative image of the Dutch army in Indonesia. ${ }^{115}$ However, a few days before the film's release, $D e$ Telegraaf published an interview with Hella Haasse. She gave the film her blessing, emphasizing that it was the work of director Hans Hylkema, that her book had simply provided him with the inspiration. She generously added, "I find that he has done this with integrity." ${ }_{116}$ On 9 June 1993, the film premiere was graced by the presence of the director, cast, Hella Haasse, the ambassador of Indonesia, the Dutch prime minister and even the queen. ${ }^{117}$

From the opening scenes onward, it is immediately clear that this is a film only loosely based on Haasse's novella. Of course, the content of a book cannot easily be detached and reproduced in film. Changes are inevitable. Nevertheless, the differences between the book Oeroeg and the film Oeroeg are extreme. It is not simply in content that the film differs from the original work. The tone and purpose are different. Pamela Pattynama argues that

\footnotetext{
112 Melief, Evaluatie, 26.

113 Ibid., 51.

114 Lipkin, Docudrama, 91.

115 "Veteranen verontrust over de verfilming Oeroeg," NRC Handelsblad, 16 September 1992.

116 Quoted in Henk ten Berge, “Hella Haasse's ‘Oeroeg' uit 1948 nog steeds actueel," De Telegraaf,

5 June 1993 .

117 Stan Huygens, “'Oeroeg': Koninklijk premiere,” De Telegraaf, 1o June 1993.
} 
the contrast between the book and the film "best exemplifies how cultural artefacts embody shifts in memories of the colonial past."118

There are similarities. Both are about a Dutch boy and his childhood Indonesian friend, Oeroeg, and how they became estranged and end up on opposite sides during the armed conflict. However, the film is primarily a war film. The purpose seems to have been not only the exploration of the relationship between the boys, but also the rectification of the Dutch view of history. As Haasse said in an earlier interview, her story had been about an emotional conflict, not a political one. ${ }^{119}$ Hylkema's work was more forthrightly political and postcolonial. It included scenes showing Dutch soldiers involved in "excesses," torturing a prisoner, shooting civilians and torching villages. However, it is also a film that demonstrated how difficult life was for the young Dutch volunteers and conscripts. They are in alien surroundings, so it is hard to tell who is friend and who is foe. The enemy uses irregular tactics and the soldiers are housed in conditions that are basic.

Hylkema's film is an attack on colonialism with little ambiguity. Pattynama notes Hueting's interview in 1969 initiated widespread "anti-colonial, guilt-ridden discourses about exploitation and racism" and this accounts for "the difference in memories embodied in book and film. ${ }^{120}$ However, it was the De Jong controversy that formed a context for the film. Pattynama argues that some scenes in the film, but not in the book, seemed to reference Jewish experience under the Nazis and apartheid in South Africa. ${ }^{121}$ Hylkema admitted that his film had a political message and that he was anti-colonial. Asked if he was worried about receiving extreme reactions, like those that targeted Hueting and De Jong, he answered that he did not fear this, seeing as the queen's presence at the premiere would be an official statement of approval. He added, "I find it scandalous how [the De Jong affair] developed and incomprehensible that De Jong changed his opinion as a historian."122

Rob de Kam warned that nearly $5^{0}$ years after the violent convulsions of Dutch colonialism, the subject was still taboo and anyone who dared to venture a critical view of Dutch actions in Indonesia could be certain of

118 Pattynama, "Cultural Memory," 181.

119 Remco Meijer, "De Stoicijnse Verwondering van Hella Haasse: 'Ik maak kenbaar wat bestond," Elsevier, 19 December 1992.

120 Pattynama, "Cultural Memory," 181.

121 Pattynama, Bitterzoet, 104.

122 Mark Duursma, "Hans Hylkema - 'Mijn verontwaardiging was groot' - Oeroeg," Filmkrant 137 (June 1993). 
receiving a large dose of verbal violence from the Indies veterans. ${ }^{123}$ However, for the most part, critics praised the film for its constructive approach to the national narrative. Henk ten Berge admired its passion and saw it as representative of the thinking of the post-war generation, adding that the screenplay had brought Haasse's book to completion. ${ }^{124}$ Stan Huygens claimed to have overheard Prime Minister Ruud Lubbers saying, "Luckily the film isn't too moralising. Both sides [Dutch and Indonesian] will appreciate it." ${ }^{125}$ Another reviewer wrote that few books in Dutch literature had been so successfully translated to the screen. Regarding the scenes of Dutch atrocities, he added that sometimes "the conflict got dirty" just like in all wars. ${ }^{126}$ Tjerke S. de Vries admitted that the original book must have been a shock to all those who believed that the Dutch cause was right, including the readers of his own Nederlands Dagblad. He recommended that both book and film could show a new generation how the Indonesian cause was justified, concluding that it "can be sobering to see history from the other side. ${ }^{127}$ A reviewer in De Groene Amsterdammer noted that the film found him rereading Haasse's novella and commented that Tjalie Robinson's vicious critique of the book now seemed "painful."128

Hans Beerekamp expressed his admiration for Hylkema's courage to finally break through the collective denial and the taboo of the national trauma. ${ }^{129}$ The following day the same newspaper published a piece with the title "The Demons in the Fatherland's Memory" written by Joop Hueting himself. ${ }^{130}$ Hueting claimed that the old soldiers now had their Vietnam film. He declared that it had been brave of Haasse to publish her novel during the armed conflict, demonstrating understanding "for the call for independence from a repressed and humiliated people." Hueting likewise expressed admiration for Hylkema's demonstration of support for the Indonesian quest for independence. However, Hueting claimed one torture scene in

123 Rob de Kam, “Hans Hylkema verfilmde klassiek boek van Hella Haasse: 'Oeroeg' - woorden in plaats van beelden," Nieuwsblad van het Noorden, 11 June 1993.

124 Henk ten Berge, "'Oeroeg' pakt stevig uit," De Telegraaf, 10 June 1993.

125 Stan Huygens, "'Oeroeg': Koninklijk premiere," De Telegraaf, 10 June 1993.

126 Pieter van Lierop, “'Oeroeg': Nederlands film van zeldzame allure," Limburgsch Dagblad, 11 June 1993 .

127 Tjerk S. de Vries, “De verschillende herinneringen van Oeroeg en Johan ten Berghe," Nederlands Dagblad, 19 June 1993.

128 August Hans den Boef, “'Oeroeg': De dubbelzinnigheid van een koloniale overgangsnovelle," De Groene Amsterdammer, 9 June 1993.

129 Hans Beerekamp, "Vervlogen illusive van polderjongen in de tropen," NRC Handelsblad, 9 June 1993.

130 J.E. Hueting, "De demonen in het vaderlandse geheugen," NRC Handelsblad, 10 June 1993. 
the film was based on his own interview of 1969 and he criticized Hylkema for softening the scene, sparing the viewer the full impact of the cruelty. Nevertheless, Hueting expressed relief that a younger generation continues the struggle to confront the demons that his generation tried to ignore.

Rudy Kousbroek was far more outspokenly critical of the film. For him, the reason the film was so different than the book had nothing to do with the inherent differences in the media but was a question of money, misunderstanding and "especially a lack of talent." He concluded that a film-maker who used the same name as a book, but changed the story entirely and deviated radically from the original intention, "is quite simply guilty of the theft of the name and the reputation of the other."131 In a second review in De Groene Amsterdammer, the judgement was also negative. Zuilhof felt the relationship in the film between the Dutch and Indonesians was a one-dimensional caricature of exploiters versus exploited that failed to say anything worthwhile about the essential trauma - "that there were Dutch people who had the feeling that they were welcome [in Indonesia] and that they understood the native population."132

The film caused a short outburst of letters to newspaper editors. A former officer wrote that good intelligence was of utmost importance and that "you don't get this from a prisoner by asking him in a friendly manner."133 A veteran in the Haagse Post/De Tijd stated that he heard the movie showed a burning village, its inhabitants massacred by Dutch soldiers, as well as a torture scene, indicating that the Dutch were no better than the German Nazis. He complained that the "good side of the coin is never revealed and that is a pity. [...] [T] he massacre which can be seen in the film is an exaggeration of the director who puts us old soldiers in a bad light." ${ }^{134}$ In the weekly Elsevier, a veteran accused Hylkema of attempting to brand all veterans as criminals, and pleaded, "[S]pare them from these repetitive, derogatory accusations." ${ }^{\prime 35} \mathrm{~A}$ week after the film's release, Henk ten Berge wrote, "Not in living memory has a Dutch film caused so many emotions and reactions to break free." ${ }^{136}$

However, perhaps it was the reputation of Hella Haasse, or the stamp of royal approval, but Hylkema faced nothing like the onslaught that had

131 Rudy Kousbroek, "Chronoclasmen en non sequiters: De verfilming van Oeroeg," NRC Handelsblad, 11 June 1993.

132 Gertjan Zuilhof, "Het landschap van kolonialisme," De Groene Amsterdammer, 9 June 1993.

133 J.J. Hendriks, letter to the editor, NRC Handelsblad, 15 June 1993.

134 G. Verwij, letter to the editor, HP/De Tijd, 17 July 1993.

135 Nic Sluis, letter to the editor, Elsevier, June 1993.

136 Henk ten Berge, "Hans Hylkema maakt veel emoties los," De Telegraaf, 17 June 1993. 
struck Loe de Jong. A film reviewer at the Leeuwarder Courant remarked that within ten years of the ending of the war in Vietnam, the Americans were making one film after another about the conflict, but it had taken 45 years for a Dutch film-maker to broach the subject. He reminded his readers of the protests that ignited when De Jong had dared to write about atrocities, concluding that it "is miraculous but pleasing that this film has not summoned the same feelings." ${ }^{137}$ Four months after the film's release, the judges at the Dutch Film Festival gave the lead actor the award for best male actor. ${ }^{138}$

Most criticism was directed towards aesthetic or cinematographic aspects of the film. Political elements were referred to, but rarely forefronted. Instead, the subject matter seemed normal. Zuilhof's criticism is poignant, that the film missed the chance to deal with the tragedy of the Dutch and especially the Indisch community during decolonization - that they became strangers in what they considered their homeland. However, this, too, was primarily an aesthetic shortcoming of the film, not a political one. To an extent, Hylkema's work, but also the press coverage surrounding it, helped normalize what had been a taboo.

Hueting's remark that the veterans now had their Vietnam film was astute. Most of the film takes place against the backdrop of a tropical jungle setting. The jungle is an example of what Lipkin calls "arenas of the performance of memory." He argues that the "arenas that frame performance become the means to make the past present." 39 The tropical setting frames the public memory, not because the viewer remembers an experience in the tropics, but because the viewer remembers other such films in such a setting - remembers, that is, Hollywood films of the Vietnam War. The frame of remembrance by which meaning was extracted from Oeroeg was found in films like Michael Cimino's The Deer Hunter (1978) and Francis Ford Coppola's Apocalypse Now (1979). That is what made the texture of the setting tangible, not because audiences had been there before, but because they had seen this type of film before. The setting was alien, yet comfortable at the same time and this framing anticipates remembering (the audience is expecting to experience the atrocities against Asian people that Western boys fighting in the jungle invariably brings). In this intertextual manner, Oeroeg reminds the viewers of (Hollywood's) Vietnam more than it reminds them of Indonesia. The American film industry had appropriated war in the

137 AW, "Beide zijden van het filmdoek," Leeuwarder Courant, 25 June 1993.

138 "Gouden Kalf voor 'de kleine blonde dood," De Telegraaf, 3 October 1993.

139 Lipkin, Docudrama, 3-4. 
jungle and colonized the public memory of decolonization's excesses. One could question whether it was the past that was made present by Oeroeg or if it was other, Hollywood, films that were made present.

The film had a soundtrack, unlike the book and unlike real life. The noise of rotating blades blended with electronic music reference films like Apocalypse Now. The sounds of the tropical night blending with the sounds of bamboo percussion reference the arena of the jungle. The film is entangled with well-used Orientalist tropes, like when it mixes Western orchestral music with Indonesian music, but it is the latter's gongs, flutes, gamelan and bamboo percussion that provide the signpost that a threat is about to emanate from the alienating world of the tropical jungle.

Baudrillard suggested that artificial memory effaces forgetting through a "restaging," arguing that films spill into a form of "aestheticized forgetting." ${ }^{140}$ Rather than the screen bringing us a memory of the event, it brings us, with its inflated hyperrealism, an aesthetic experience that replaces the event. For Baudrillard, history becomes myth and finds its place in the cinema. ${ }^{141}$ Cinema's attempt at "an absolute correspondence with the real" leads to the "disappearance of history."142 Substituting the reality of film for the historical event results in unremembering. The historical event is replaced by the cinematic experience.

In Hyklema's Oeroeg, it is not only the Indonesian-Dutch conflict that is represented. Something more glamorous is taking place, namely, Holland's Hollywood-style war. Hylkema's work comments on the conflict of 1945-1949, but it is chiefly a restaging rooted in Hollywood. References are partially to historic events, remediating the likes of the Hueting interview, but owe a great deal to other films, television news reportage and photographic images, like the photograph of the baby in the massacred village in Aceh in 1904. The image of the crying baby appeared in Nieuwenhuys' photo collection, and it reappeared for a moment in De Jong's De Bezetting. It was recycled again in Fons Rademaker's anti-colonial film adaption of Multatuli's classic novel Max Havelaar. The Dutch colonial army has massacred the inhabitants of a village and a baby sits crying, surrounded by a pile of corpses, similar to the original photograph. Hylkema's scene of the crying baby is far less radical, though according to Pattynama, it "must be a visual echo of the infamous Aceh photo" as well as a reminder of Hollywood's The Deer Hunter 
and Apocalypse Now. ${ }^{143}$ In Hylkema's film we see the protagonist running into the already burning village (we never actually see the Dutch soldiers setting fire to it), stumbling past the corpses of villagers, and when he encounters the crying baby inside the hut, he picks it up. Indeed, he is the heroic rescuer of the baby. The effect is different from the radical impact of Rademaker's scene. Hylkema's repurposing of this image is an example of the sign breaking free from its documentary origin in 1904, becoming a sign that triggers a repulsive response in the late twentieth century. However, it has no direct referential value when it comes to decolonization.

The impact of the De Jong debate had been to prepare the Dutch public for more news of atrocities. When it came to Oeroeg, the approval of Hella Haasse, and most of all the queen, had further prepared the audience to keep an open mind. Finally, the arena of the jungle, well known from American movies, provided the framework for what could be expected. This contributed to the sense that what was being enjoyed on the big screen was normal. When one reflected upon the fact that these were Dutch soldiers carrying out atrocities, it was easy to agree with the reviewer who had commented that that is what happened in war. Indeed, in a documentary broadcast on Dutch television the week after the film's release, one of the film's actors, Peter Faber, said: "As soon as there is war, there is no good and evil." ${ }^{144}$ Hans Hylkema, by providing entertainment that referenced recent Hollywood movies, had translated the existence of Dutch atrocities from the taboo to entertainment.

Within four years, a grand epic covering the entire period from 1940 to 1949 was released. Examining the press reactions to this second film will reveal just how deep normalization had gone. Two hugely successful French films released around the same time as Oeroeg may have inspired director Orlow Seunke: L'Amant (1992) and Indochine (1992). ${ }^{145}$ Gordel van Smaragd (The emerald belt) premiered at the seventeenth Dutch Film Festival and during an interview, Seunke commented that Dutch colonial history during the 1940 s provided "a treasure of fascinating incidents. ${ }^{146}$ The violence of World War Two, Japanese internment camps, the Bersiap period and the War of Independence did not constitute traumatic memories, but simply formed "a treasure of fascinating incidents."

143 Pattynama, Bitterzoet, 105.

144 The documentary is included in the DVD version of Oeroeg: Oeroeg, directed by Hans Hylkema (Paramount Home Entertainment, 2005).

145 Pattynama, Bitterzoet, 119.

146 Quoted in Erik Koch, “Orlow Seunke verliefd op Indonesië,” De Telegraaf, 25 September 1997. 
In the conservative De Telegraaf, a reviewer was impressed by the film's wonderful images, outstanding action scenes and lack of sentimentality. ${ }^{147}$ The Protestant Trouw praised the magnificent shots of the Indonesian landscape, found the love story to be believable and considered the mixing of archival film footage and fictional scenes to be ingenious. ${ }^{148}$ The leftof-centre De Volkskrant judged it a "quality film" with a beautiful romantic story, supported by a mix of fact and fiction and a lack of sentimentality. ${ }^{149}$ The liberal NRC Handelsblad found Seunke's work to be a real chronicle of decolonization and "an impressive attempt to do justice to the viewpoints of all those involved in Indonesian decolonization." ${ }^{150}$

On the other hand, the NRC Handelsblad also pointed out a weakness of the film - the balanced treatment of the historical structure meant that the dramatic demands of the story suffered. ${ }^{151}$ In the weekly Elsevier, Rob van Scheers argued that the film lacked drive and was simply a collage of incidents. ${ }^{152}$ The Algemeen Dagblad was the newspaper most opposed to the film. The black-and-white original film footage irritated Ruud Kuyper, because it felt like sitting in a history lesson. ${ }^{153} \mathrm{Ab}$ Zagt agreed, claiming the film was a half-soft documentary with a romance that lacked any passion, but worse was Seunke's attempt to send his audience back to school. ${ }^{154} \mathrm{He}$ declared the film was clichéd and a bad history lesson. ${ }^{155}$ But reviewers never ventured beyond the norm of what is acceptable in the world of criticism. Some in the conservative press, while possibly politically motivated, verbalized criticism in a way that made it seem like it was the aesthetic elements of the film that are being critiqued. The contestation of memory was never made explicit.

In Het Parool, Seunke was asked if he was worried that he might become involved in some terrible polemic. He answered that he need not worry because everything that he shows in the film "is based on memoirs, photo albums and film archives." ${ }^{6}$ In a second interview he admitted, "I am not

147 Erik Koch, "Passie en historie in 'Gordel van Smargagd," De Telegraaf, 2 October 1997.

148 Hans Kroon, "Orlow Seunke is een dictator, maar wel een charmante," Trouw, 22 September 1997.

149 Peter van Bueren, “Gelukkig weet Seunke afstand te bewaren," De Volkskrant, 2 October 1997. 150 Hans Beerekamp, "Seunke geeft dekononisatie eindelijk een echte kroniek," NRC Handelsblad, 1 October 1997.

151 Ibid.

152 Rob van Scheers, "Mag ik je kampong zien," Elsevier, 27 September 1997.

153 Ruud Kuyper, "Liefde en de feiten," Algemeen Dagblad, 26 September 1997.

154 Ab Zagt, “Orlow Seunke mist passie," Algemeen Dagblad, 25 September 1997.

155 Ab Zagt, "Orlow Seunke wil veel maar bereikt weinig," Algemeen Dagblad, 2 October 1997. 156 Quoted in Mark Moorman, "Het gefluister van de vlag," Het Parool, 28 August 1997. 
somebody who wants to make political statements with a film." Furthermore, he claimed that everything "is historically correct."

Seunke choose to include archival black-and-white film footage with voice-over in his full-colour film epic - the so-called history lesson that annoyed some reviewers. He explained that he faced the problem of having to place the love story against a complicated and shifting historical background. He looked at how other films had done this..$^{15}$ The film footage contextualized the love story. It was a technical solution to a narrative problem. The history lesson was necessary because the Dutch were ignorant of their colonial history. Decolonization supplied a treasure trove of "fascinating incidents," but the audience needed to be educated in order to enjoy them.

Gordel of Smaragd provides an example of the normalization of decolonization in the world of the cinema, a process triggered by Oeroeg but enabled by the popularity of French as well as Hollywood movies set in a similar arena. The familiarity of the arena made these films easy to relate to. They restaged scenes of horror, but were simultaneously familiar and comfortable to watch. These forms of entertainment enacted remembering and unremembering.

\section{The Boomsma Affair}

Months after the release of Oeroeg, De Groene Amsterdammer republished the letter from an officer, originally published in February 1949, reminding the Dutch public how their military forces burned Indonesian villages, shot civilians and practised military terror. ${ }^{159} \mathrm{~A}$ short introduction informed readers that the original article had the impact of a bomb, but that all of the outrages were eventually hushed up. ${ }^{160}$ The following week the magazine's editor, Martin van Amerongen, drew attention to the work of Chris van Esterik, in which the latter claimed that former Dutch members of the SS had been sent to fight in the Dutch "police adventures." ${ }^{\text {"161 }}$ It was a deliberate

157 Quoted in Joost Niemoller, “Indo-vrouwen Zijn Prachtig," De Groene Amsterdammer, 24 September 1997.

$15^{8}$ Quoted in Ab van Ieperen, "De puzzels van Orlow Seunke," Vrij Nederland, 4 October 1997.

159 "Djokja, Februari 1949: Een officier schrijft aan zijn vrienden," De Groene Amsterdammer,

8 September 1993 .

160 Ibid.

161 Martine van Amerongen, "Reclassering anno 1949," De Groene Amsterdammer, 15 September 1993 . 
provocation, coinciding, as it did, with the "Boomsma affair," in which a Dutch novelist was brought to court for comparing the deeds of Dutch soldiers to the deeds of the Nazi SS.

In 1992, Graa Boomsma published his novel De laatste tyfoon (The last typhoon), a reworking of his earlier De idioot van de geschiedenis (The idiot of history). The novel explored the relationship between a son and a father who fought in the War of Independence. Boomsma based the novel on his own postmemory experiences, his father having participated in the war. Boomsma's father had remained silent about his experiences until the Hueting interview of 1969 . His father had died at the early age of 52 . To honour him, Boomsma felt compelled to tell his story. There are parallels with the postmemory works of Jill Stolk, Marion Bloem and Adrian van Dis. Once again, the scars of the father have passed to the second generation. However, Boomsma also meant his book to be a critical attack on the authorities who had sent young men to fight in a dirty war. Boomsma's novel took a knife to the roots of Dutch unremembering, dragged it before the bar of judgement, and finding it wanting, condemned it. ${ }^{162}$

In an attack on the historical guild, the novel's narrator writes that he had learned everything about the American Civil War in school, "but the final years of our East Indies colonialism remained a black hole." ${ }^{163}$ The narrator burns with curiosity about what his father, Kerst, must have experienced as a conscript. The history of the conflict is a dark hole that "I descend into, like a half-baked archaeologist who studies the earth, layer after layer, and I come back up with mud and blood on my hands and scratches on my face" (119). He aims "to wriggle a hole with my pen in the wall of the past" (27). He offers a picture of young men, drafted into an army and forced to fight in an alien environment, because politicians back in The Hague made mistakes. Young men like Kerst are brutalized by the conditions of warfare.

Kerst finds himself working as an assistant prison warden where Indonesian prisoners are being interrogated. He cleans up prisoners after Dutch jailers have tortured them (151). When going on patrol it becomes routine to burn down entire villages $(108,168)$. The postmemory narrator imagines a life consisting of heavy drinking and sleeping with young women (135). 
The narrator does not deny that the attempt to reconstruct an image of the past is based mainly on imagination, "foolish and unreliable writer of history that I am" (125). On the other hand, "Every reconstruction is a matter of imagining" (89). Boomsma was staking a truth claim here. The brutality of the Dutch forces was not fiction. Boomsma was not claiming that he made it up - it was not simple fantasy. The representation that he (re)constructed was of the Dutch pursuing a murderous war for selfish ends, later covered up and forgotten (or unremembered). Unremembered until, as Kerst's wife, the narrator's mother, puts it: “About ten years ago I saw on the television an episode of Achter het Nieuws about how bad the Dutch troops had behaved on Java. I had never known that" (25).

The narrator asks: "Is it true that historical phenomena are like boulders that, when dropped in the deep sea of memory, cause waves that grow bigger and bigger?" (45). As it turned out, Boomsma had dropped a boulder and the waves quickly grew bigger. The novel, like the works of Schilt, Zwaan, Varenne and Laurens, might have remained little noticed by the public, but Boomsma was interviewed in the Groningen newspaper, Nieuwsblad van het Noorden. ${ }^{164}$ Journalist Eddy Schaafsma described how Boomsma's novel filled in a "black page from the Fatherland's history" and showed "why the processing of the Dutch 'Vietnam trauma' has taken so long." Boomsma told Schaafsma: "America processed her Vietnam past, made films, wrote a whole pile of books; in the Netherlands you can count them on the fingers of one hand." He claimed that the task of the author was "to be the memory of humanity." However, Boomsma also uttered words that would cause a great deal of trouble: "Shortly after the war the communists wrote: 'Don't turn our lads into the SS.' I think that reflected what was happening." The title of the interview was Boomsma's statement: “They Weren't SS, No, Even Though, Because of the Things That They Did, the Comparison Could Be Made." Comparing former Dutch soldiers to the hated SS was an eye-catching headline, but it landed them in court, initiating the so-called Boomsma affair - a public debate that would lead to hundreds of publications in newspapers during the following few years.

Veteran Lodewijk Buma, having read Boomsma's comparison with the SS, decided to take Boomsma and Schaafsma to court for defamation. The court in Groningen in 1993 decided that there was no case to be made. In September 1993, Buma lodged a complaint in the court in Leeuwarden, in 
the province of Friesland. ${ }^{165}$ In November 1993, the Prosecutor General in Leeuwarden proclaimed that Boomsma and Schaafsma should be prosecuted for defamation, and sent the case back to the court in Groningen. ${ }^{166}$ The international writer's organization PEN expressed its concern by sending a letter of protest to the Dutch Minister for Justice. ${ }^{167}$ The case opened on 26 May 1994 and the public prosecutor called for Boomsma and Schaafsma to be fined 500 guilders. ${ }^{168}$ On 9 June the defendants were pronounced not guilty. ${ }^{169}$ Buma and the Prosecutor General appealed to the High Court in Leeuwarden. Over a hundred veterans demonstrated against Boomsma outside the courtroom on 12 January $1995 .{ }^{10}$ However, on 26 January the court decided that there had been no instance of defamation. ${ }^{171}$

Throughout these years, Boomsma's name was seldom out of the news, and like during the De Jong affair, newspapers became the vehicle for discussing decolonization. If veterans like Buma had hoped to smother discussion of the military behaviour during the decolonization conflict, then their plan backfired. On 29 September 1993, De Volkskrant published not one, but two articles on the case. In the first, Boomsma was quoted as saying, "the Netherlands has not yet processed the war in the former Dutch East Indies. ${ }^{\prime 172}$ Boomsma himself wrote the second article. ${ }^{173} \mathrm{He}$ wrote, "I feel this has attacked my freedom as a writer." Referring to the article by Van Amerongen in De Groene Amsterdammer, he asked: Why is it still not generally known that "under the patronage of the Dutch army 15,000 to 30,000 ex-SS were sent into the kampongs?" He asked: "How come the

165 "'Uitspaak Boomsma is smadelijk," NRC Handelsblad, 29 September 1993.

166 "Boomsma vervolgd," NRC Handelsblad, 19 November 1993; "Hof: OM moet schrijver en journalist wegens smaadschrijft vervolgen," Nieuwsblad van het Noorden, 19 November 1993; "Auteur toch vervolgd na vergelijking met SS," De Volkskrant, 19 November 1993.

167 "PEN verontrust over process tegen Graa Boomsma," NRC Handelsblad, 24 May 1994; "PEN neemt het op voor Boomsma," De Volkskrant, 25 May 1994.

168 "Geldboete geeist tegen auteur Graa Boomsma," NRC Handelsblad, 27 May 1994.

169 "Vrijspaak voor Graa Boomsma," NRC Handelsblad, 9 June 1994; "Vrijspaak in zaak van Indië veteranen," De Telegraaf, 10 June 1994; Gerad de Kleine, "Journalist NvhN niet schuldig van smaad," Nieuwsblad van Friesland, 10 June 1994; "SS vergelijking niet strafbaar," Het Parool, 10 June 1994.

170 "Indië veteranen demonstreren voor respect," De Volkskrant, 13 January 1995; “Protest bij process," Trouw, 13 January 1995 .

171 "Vrijspraak voor schrijver Boomsma," Leeuwarder Courant, 26 January 1995; "Hof in Leeuwarden speekt schrijver Graa Boomsma vrij," Trouw, 27 January 1995.

172 "Schrijver wacht wellicht process na vergelijking Indië-gangers met SS," De Volkskrant, 29 September 1993 .

173 Graa Boomsma, "Politionele acties blijven een zwart gat in ons geheugen," De Volkskrant, 29 September 1993 . 
Netherlands deals so badly with her past, particularly when it comes to her war crimes in Indonesia? Why is the colonial war that we ignited still referred to euphemistically as the 'police actions'?" He referred to this period as a "black hole in our memory."

Historian Thomas van der Dunk penned a letter to the editor in De Volkskrant in which he challenged the conservative minister Fritz Bolkestein to support Boomsma in order for there to be freedom to openly speak about the "nature and volume of war crimes committed by Dutch soldiers in Indonesia." ${ }^{174}$ The renowned anti-establishment critic Theo van Gogh wrote, "denial that the tortures and bloodbaths described in Boomsma's book are similar to those of the SS is a perfidious stupidity."175 The affair took a surprising twist in a radio programme when the chairman of the Old Soldiers Legion expressed his disagreement with Buma: "There will certainly have been a number of lads who misbehaved themselves like that. ${ }^{176}$ Manuel Kneepens of Erasmus University wrote that the behaviour of Westerling on South Celebes was comparable to the SS's worst atrocity on Dutch soil, the destruction of the village of Putten. However, while the officer responsible for Putten was sentenced to death, "Westerling wasn't even charged." 177 Kneepens went on: "But it is Boomsma, and no one else, who is now being legally prosecuted. That means that the events on South Celebes, via his case, will indirectly be legally evaluated." It was the army of the Indies, as much as Boomsma and Schaafsma, that was on trial.

In February 1994 Trouw ran an interview with Boomsma entitled: "Graa Boomsma and the Gaps in the History: The Netherlands Has Not Yet Processed Her Past." Boomsma was quoted as saying: "Why do the Indonesian people feel no vindictiveness against the Netherlands? Because the people there have processed their past. The Netherlands has not done that. There has never been a discussion in the Netherlands about the colonial war. There has only been talk of incidents. ${ }^{178}$ The following day the NRC Handelsblad came out in favour of Boomsma, with an article entitled "Boomsma: Indies Veterans Defamation Process Absurd." Reinjan Mulder referred to the absurdity, that while Boomsma is being prosecuted "those guilty of the police actions

174 Thomas van der Dunk, letter to the editor, De Volkskrant, 14 November 1993.

175 Theo van Gogh, "Indië verloren, rampspoed geboren," HP/De Tijd, 26 November 1993.

176 Rene Zwaap, [untitled], De Groene Amsterdammer, 12 January 1993.

177 Manuel Kneepens, “De schrik komt er geweldig in,” Trouw, 23 December 1993.

178 Jet Kunkeler, "Gra Boomsma en de gaten in de geschiedenis: Nederland heeft zijn verleden nooit verwerkt," Trouw, 22 February 1994. 
were always allowed off. People like Raymond Westerling." 179 The following day, the day of the court hearing in Groningen, the NRC Handelsblad gave the floor to Boomsma. His article was entitled: "The Past Stays Active, It Festers, Bursts Out." ${ }^{180}$ The article was identical to the statement that Boomsma read out in court later that day. He warned that a ghost hangs over the Netherlands, "the ghost of an unprocessed history." He compared the past with nuclear power, asking, What do we do with the unprocessed radioactive waste?

Historian Elsbeth Locher-Scholten's reasoned article, which used the term "war crimes" in its title, tried to put the entire matter into historical perspective. She argued that in some ways Boomsma should be grateful to Buma, because thanks to the latter's accusation, the "repressed colonial past" had been dragged into the open. ${ }^{181}$ However, while this might have been necessary for the public, Locher-Scholten claimed there had already been consensus among historians that "the Netherlands, just like other countries in war, has been guilty of unnecessary violence, military excesses or war crimes." She mentioned the works of Van Doorn and Hendrix from 1970 (neither a historian), Willem IJzereef from 1984 and Loe de Jong's twelfth volume from 1988. She correctly pointed out that already in 1949 accusations of excessive violence had led to questions in parliament, but after Indonesian independence, this had disappeared into "the deepest regions of the collective unconsciousness." Hueting had broken this silence in 1969. She concluded: "It seems to cost the Netherlands quite some trouble to recognize that human good and evil don't keep to national frontiers; that the Netherlands doesn't have a patent on sanctity; that a justified war does not exist and so the Netherlands is responsible for war crimes, too."

It would be mistaken to conclude that the entirety of Dutch academia was happy with Boomsma. J.A.A. van Doorn published an article with the cynical title, "Graa Dreyfus." ${ }^{182}$ Van Doorn offered two reasons for why the affair had reached such heights of publicity. Firstly, it had been the next link in a chain of incidents "that accompanied the processing of the post-war Indies trauma." Secondly, because of "the pronounced vindictiveness by which these [...] issues are exaggerated." Van Doorn was irritated by Boomsma's

179 Reinjan Mulder, "Boomsma: Process wegens belediging Indie-strijders absurd," NRC Handelsblad, 25 May 1994.

180 Graa Boomsma, "Het verleden blijft actief, het woekert door, barst naar buiten," NRC Handelsblad, 26 May 1994.

181 Elsbeth Locher-Scholten, "Nederland leert niet van oorlogsmisdaden," NRC Handelsblad, 20 May 1994.

182 J.A.A. van Doorn, “Graa Dreyfus," HP/De Tijd, 17 June 1994. 
attitude of "the hero before the firing squad." He claimed that Boomsma saw himself as a modern Multatuli, and that his novel reflected "pretentious claptrap." This attack seems difficult to comprehend. He accused Boomsma of libelling old soldiers by including highly improbable scenes, but as Esther ten Dolle has pointed out, "Van Doorn does not explain why Boomsma's inventions are improbable." ${ }^{183}$ Van Doorn had also attacked De Jong in the mid-1980s. Unlike his colleague Wim Hendrix, he had not cooperated with Roelof Kiers during the making of Indonesia Merdeka. ${ }^{184}$ He may have felt that Boomsma was pretentious and enjoying the role of the persecuted hero, but the principal of setting the historical record straight surely was what was at stake. Yet, Van Doorn accused Boomsma of having written a bad book, because it mixed fact and fiction. What's more, Van Doorn gave an example of a passage in Boomsma's book, which was based on research by Van Doorn. Van Doorn and Hendrix had written, "Violence justifies itself," while Boomsma had changed this to "Violence defends itself."

While the Boomsma affair brought unsought publicity for the author, Adriaan van Dis reached a wide public in 1994 with his postmemory novel Indische Duinen (Indische dunes). Nathan Sid had been a slim volume. Now Van Dis returned to the same family, telling a substantial tale of the long afterlife of decolonization. Van Dis offered the reader encounters with many of the aspects of decolonization that we have already come across. Those who lost their homes under the Japanese, and again because of Indonesian nationalists, learn the art of adapting and living life in a manner as if the need to escape might again erupt. ${ }^{185}$ We read of the intense silence and attempts at forgetting of those who suffered, and how this is passed down to the next generation (40-41, 66-67). We read of episodes of abuse in Japanese camps and of arguments regarding comparisons with German concentrations camps (40). Characters deal with trauma, years after the events, by joining therapy groups, though the main character, Nathan, has his serious doubts about dwelling on victimhood (63-64). Ex-camp prisoners struggle with the Dutch government to get their salaries and pensions paid (65-66). An Indo father who died fighting for the Dutch is considered a hero by his daughter, but Nathan adds, "A sucker, I thought, he fought for the wrong party, choose the side that had stolen his land and resisted the nationalists" (68-69). Van Dis described the feelings of fear during the Bersiap violence (75-76), the

183 Ten Dolle, "Morality," 177.

184 Peter Schumacher, “TV vanavond: zeer unieke 'Indonesia Merdeka," NRC Handelsblad, 1 December 1976.

185 Van Dis, De Indië Boeken, 14, 49. 
feeling of shame for having survived (124), the homesickness and the cold reception that the repatriates met upon arrival in the Netherlands $(97,113$, 122-123).

Despite some lukewarm reviews, ${ }^{186}$ within two years of publication, Indische Duinen had sold more copies than any other literary novel in Dutch history. ${ }^{187}$ It received two book prizes in 1995 and was shortlisted for the country's two most prestigious book prizes. ${ }^{188}$ It ignited no controversy and resulted in no protests, focused, as it was, not on combat or war crimes, but on the postmemory scars of a narrator who could not properly mourn or understand loss for which he lacked direct experience. The narrator of the novel suffered from the brutality that his father endured, but this brutality was never foregrounded, always remained hidden.

\section{The Poncke Princen Affair}

Poncke Princen was the most famous Dutch deserter of the war. Drafted into the army in 1945, not only had he deserted, he had fought for the Indonesians. He became an Indonesian citizen and remained there for the rest of his life, active in politics and human rights. Princen had family in the country of his birth, with whom he corresponded. In 1993, Princen applied for a visa to visit the Netherlands, igniting a new controversy.

In the October 1993 edition of the magazine of the former Communist Party, Joop Morriën used the Poncke Princen controversy to call for a rethink of the colonial war. He claimed that the refusal of a visa for Princen was another indication of "the inability of successive Dutch governments to come clean regarding the post-war colonial past." ${ }^{189}$ More widely read were two articles by ex-conscripts to the Indies army, published in De Volkskrant the same month. Jan van der Horst argued that the soldiers had been lied to, had served their country well, had suffered and had never received an apology. On the other hand, A. Huijvenaar claimed that stories about the Dutch army in Indonesia were "saturated by a nasty mendacity that one

186 Alle Lansu, "Een Indische doos van Pandora," Het Parool, 23 September 1994; Gertjan van Schoonhoven, "Door de jungle van zelfbedrog," NRC Handelsblad, 30 September 1994; Marc Reugebrink, "Schrijven in een glazen kamer," Nieuwsblad van het Noorden, 30 September 1994;

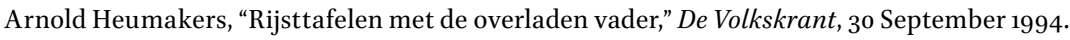
187 Sars, Adriaan van Dis, 100.

188 Ibid., 136.

189 Joop Morriën, "Waar blijft erkenning dat de politionele actie fout was?," Politiek en Cultuur (October 1993). 
should be ashamed of." He was disgusted with the acceptance of the story of former members of the SS being conscripted into the army. ${ }^{190}$

A television programme unexpectedly confronted veterans with a face-to-face confrontation with Princen. ${ }^{191}$ Veteran Dirk Hartman was in the studio before a live audience. Hartman allowed that the war had been wrong, but he could not tolerate comparisons with the Germans, and would refuse to talk with the traitor Poncke Princen. Nevertheless, the programme makers had a live connection with Princen at the German-Dutch border. Hartman trembled when confronted with Princen on the monitor. The ensuing discussion between veterans in the audience and Princen was heated. However, there seemed to be consensus regarding the nature of the war, with veterans using words like "Repressed past," "suppressed memories of a dirty war," "colonial war," "the Netherlands stood on the wrong side" and "unjust war." One participant, the author Jan Schilt, argued that it had been "a dirty war - not police actions" and that prisoners and wounded had often been killed by the Dutch. The programme included an interview with the Dutch Minister of Agriculture at the time of the war. He admitted that "we made the wrong decision on military intervention." The fact that most veterans in the show refused to speak to Princen made the news. As one journalist pointed out, this made for good television, but in an already polarized public debate, it convinced the veterans that they were misunderstood. ${ }^{192}$

The question if Princen should be permitted to return continued into 1994. Historian Paul Ophey argued that as long as the Dutch government did not issue an official statement regarding guilt for the conflict, than it would remain difficult for members of the public to realize that, historically speaking, Princen had had more justice on his side than the soldiers who had remained loyal. ${ }^{193}$ A reader of the NRC Handelsblad complained: "I knew everything about the atrocities of the Nazism, the Holocaust and the Vietnam War, but nothing about the decolonization of 'Our Indies.' [...] [I]t was barely mentioned in the history textbooks. ${ }^{194}$

In late 1994, Hans van Mierlo, Dutch Foreign Minister, personally authorized the issuing of a visa to Princen. It was agreed that Princen would

190 A. Huijvenaar, "Indonesia bestaat bij de gratie van Nederlands-Indië," De Volkskrant, 21 October 1993.

191 De Tijd Staat even stil, NCRV, 22 June 1993.

192 Peter Sierksma, "Het praat niet makkelijk met Ponkce Princen erbij," Trouw, 20 October 1993.

193 Paul Ophey, "Schooljongenspolitiek tegenover Indonesia," De Gelderlander, 14 June 1994. 194 Letter to the editor, NRC Handelsblad, 9 April 1994. 
not make any political statements during his visit. This was scheduled for December 1994. Anthropologist Nico Schulte Nordholt accused the veteran lobby of having swept history under the carpet. ${ }^{195}$ Princen, as agreed, refrained from making political statements, but soon after he left the country, De Volkskrant published an interview with him, asking detailed questions about his personal role fighting for the Indonesians. He accepted that there was brutality on both sides - "It was war" - but he believed that the Dutch government should offer apologies to Indonesia because it had started a colonial war. ${ }^{196}$

The debate now focused around the role of the army during the period from 1945 to 1949 and put the veterans, whether they wanted this or not, again in the limelight. De Groene Amsterdammer ran a couple of articles on the veterans that captured the two extremes. The first was a profile of the veteran Ted Meines. ${ }^{197}$ As chairperson of the Veteran Platform Meines had managed to unite 32 different veteran groups under one umbrella representing the 150,000 veterans in the country. He had not only fought in the "police actions," but had also been active in the Dutch resistance against the Nazis. In fact, he had saved the lives of dozens of Jewish children during the war. What made the article so poignant was that the author of the article, Max Arian, was one of those children. In the opening paragraph, Arian introduced Meines as the man who had appeared on television to simply answer "no" to the question if Poncke Princen should get a visa. However, Arian told of another side of Meines: "I know him mainly as the old resistance man from the NV group, the group that during the war, as a Jewish child, saved my life." Meines admitted that he was not the sort who would join the anti-Boomsma demonstrators outside the courthouse, but he expressed his frustration: "The Indies veteran has always felt picked on, that we played a bad role in the decolonization process. I have to reject that. We never did anything except what the government of the time ordered. [...] [G]ratitude is what we have never gotten." He condemned "historians and pseudo-historians and the media who want so much to point a finger at those who were wrong." Meines also rejected the too easy comparison between Vietnam and Indonesia, which Hueting had made. He asked the media to,

195 Maurits Schmidt, "Sterke veteranenlobby poetst geschiedenis weg," Het Parool, 27 December 1994.

196 Wielcher Hulst, "De weg is gebaand voor vorm van eerherstel," De Volkskrant, 10 January 1995.

197 Max Arian, "Een veteraan en zijn oorlog," De Groene Amsterdammer, 18 January 1995. 
"try to give the veterans, who are now near the end of their lives, a little more time where they have the feeling that what they did was responsible."

Some months later, De Groene Amsterdammer offered a different aspect of the veterans with portraits of two veterans, J.H.C. Ulrici, who went to the war as a volunteer, and T.E. Spier, a professional soldier who had risen to the position of lieutenant colonel. ${ }^{198}$ On the one hand, Ulrici seemed to deny that excesses had taken place, emphasizing that his men were always on their best behaviour. However, he belittled some well-known atrocities: "They talk about Westerling on Celebes. Now, well, that was not really that bad." Some of what he said contradicted the image he had painted of disciplined soldiers who kept to the rules:

We were hard, rock-hard. That is logical. If you find your lads with their penis cut off and in their mouth, their legs sawn off with the saw thrown by their side, and you catch the guy who has done it, then you don't offer him a cup of espresso. Then you give him absolutely no consideration, no mercy. And that's what they call excesses.

Ulrici and Spier had been tasked in August 1949 with hunting down and killing Poncke Princen. They killed Princen's wife and between fifteen (according to Speir) and nineteen (according to Ulrici) of his soldiers. They found Princen's diary, which, Ulrici claimed, was filled with pornographic drawings, communist slogans, descriptions of his ambushes on Dutch soldiers and expressions of his frustration at not being made an officer in the Dutch army. Ulrici referred to Princen as "a prick," using the same term to describe Hueting. He opposed any attempt to assassinate Princen during his visit to Holland, but admitted that he would love to have kidnapped him "and given him a good smack and kicked him out of this country."

\section{Television}

In a criticism of the indifference demonstrated by the guild of historians, Stef Scagliola has written that journalists, especially film-makers, "had become interested in the war experiences of veterans and made up for the lack of interest of historians." 199 In 1989, 20 years after he had presented the famous Hueting interview, Herman Wigbold was involved in making De Kampong 
staat in brand (The kampong is on fire). He claimed his objective was not only to show what went wrong in Indonesia, but also what the average soldier had had to endure. He added that soldiers were not responsible for the terrible violence, but the politicians who had sent them to fight. ${ }^{200}$ The Leeuwarder Courant mentioned some veterans of the conflict had expressed their concerns, but that Wigbold did not expect the documentary to cause a great deal of controversy. ${ }^{201}$

The 9o-minute film showed brief images of actual fighting, including dead and wounded. Soldiers told of killing and being injured, taking part in executions, witnessing hard interrogations. ${ }^{202}$ Interviewees admitted to carrying out excesses that they later regretted. One confessed he saw hundreds of summary executions under Westerling, but had no problem as it was the only way to restore peace and order. All agreed that the soldiers became demoralized, felt betrayed by their political leaders and complained that they never received the needed support after demobilization. One remarked: "The Netherlands suppresses its defeat in a great silence." Peter Schumacher of the NRC Handelsblad expressed his disappointment as, he felt, bearing in mind other documentaries such as Indonesia Merdeka (which had just been broadcast for the third time) and "Ons Indië" voor de Indonesiërs, and despite the contributions of historian Petra Groen, De Kampong staat in brand had little new to offer. ${ }^{203}$

On the day marking 50 years since the end of World War Two in Asia, the commercial television station RTL 5 broadcast a documentary about the Dutch massacre in the village of Rawagede. Fassuer's Excessennota of 1969 had claimed that in 1947 the Dutch had killed about 150 fighters in this action and had executed 20 civilians. No prosecutions had taken place. As we have already seen, soldiers had spoken of the massacre during the making of a 1983 radio programme, but this had not been broadcast. Now, De Excessen van Rawagedeh maintained that the researchers of 1969 had vastly underestimated the number of dead, mentioning a total of 431 civilians massacred by Dutch soldiers. Journalists spoke of a Dutch My Lai massacre. ${ }^{204}$

200 Hans Visser, “De Kampong staat in brand," Het Vrije Volk, 8 September 1989.

201 "Documentaire Indonesië pakt kritiekloze pers aan," Leeuwarder Courant, 8 September 1989. 202 De Kampong staat in brand, RVU, 9 September 1989.

203 Peter Schumacher, "Het wachten is nog steed op de eerste echte film over 'het Nederlands Vietnam," NRC Handelsblad, 9 September 1989.

204 Frans van der Waals, "Rawagedeh krijgt contouren van een Nederlands My Lai," Het Parool, 10 August 1995 . 
The film crew had gone to Rawagede and interviewed five survivors of the massacre. It was a piece of sober oral history. However, at only 30 minutes in length, and based entirely on eye-witness testimony, Addie Schult of Het Parool was not completely convinced. ${ }^{205}$ Some objected that broadcasting a documentary about Dutch military atrocities on the anniversary of the Japanese surrender and the liberation of Dutch prisoners was disrespectful. ${ }^{206}$ However, many found the new findings convincing and disturbing. ${ }^{207}$ Some correctly pointed out that this might have legal consequences, leaving the Dutch government liable to paying compensation. ${ }^{208}$

Tom Verheul's Tabee Toean: Op patrouille in Nederlands-Indie (Tabee Toean: On patrol in the Dutch East Indies) was released in cinemas on 17 August 1995, to coincide with the anniversary of the Declaration of Independence of 50 years earlier. The following year it was televised twice and again in 2000. Verheul built his film around interviews with five Dutch veterans. Using De Graaff's format of the pilgrimage, in which the old warrior returns to the scene of trauma, he brought four of them back to Indonesia, where they narrated their stories. Like Kiers' Indonesia Merdeka, Verheul included interviews with Indonesians, describing their attacks on Dutch soldiers and on fellow Indonesians.

The encounters between the Dutch and Indonesian veterans provided the film with poignant scenes. A Dutch soldier returned to the village where he killed an innocent man, met the man's family and learned his name. Another met a woman who survived an attack on a village that he had been a part of. Accompanied by her, he laid flowers at a monument commemorating hundreds of villagers killed when the Dutch unleashed over 3,00o grenades into the village. We hear of prisoners being killed routinely and villages burnt. The SS are mentioned more than once. One veteran, stumbling over his words, says that all excesses should be brought into the open, but admits that he still finds it difficult: "In guerrilla warfare there are no rights," he says. He admitted that he has wrestled his entire life with his memories.

In an interview in Vrij Nederland, Verheul claimed that he had wanted to make a film about ordinary men who had gone to fight for noble reasons but were caught in a spiral of violence. He wanted to find out "how our lads, our fathers, brothers, uncles and neighbours, behave once they become a

205 Addie Schult, “De excessen van Rawagedeh," Het Parool, 15 August 1995.

206 S. Paul, letter to the editor, Het Parool, 22 August 1995.

207 "Massamoord op Java in 1947 onthuld," Trouw, 9 August 1995; “Commentaar: Rawagedeh," Trouw, 11 August 1995; Marc van den Eerenbeemt, "Een sobere getuigenis van militair ingrijpen in 1947," De Volkskrant, 15 August 1995.

208 Kees Schuyt, "Vergeven en vergeten," De Volkskrant, 21 August 1995. 
part of an army of occupation." ${ }^{209}$ Pierre Heijboer wrote that it was clear that "small excesses" like the shooting of a few prisoners had been the most normal thing in the world. ${ }^{210}$ Pieter Kottman compared what he saw in Verheul's film with the atrocities taking place in Yugoslavia during the $1990{ }^{211}$ Tabee Toean, which had received financial assistance from the Foundation for Veteran's Services, was widely and positively reviewed and has had a long afterlife. It formed an important element in an exhibition at the Museum of the Dutch Resistance in Amsterdam in 2016. ${ }^{212}$

When considering the Hueting interview and the many television documentaries, we must agree with film historian Chris Vos: "If, in the Netherlands, a collective repression exists regarding the crimes that were committed in Indonesia, then one cannot blame the television for this."213 We can hardly give responsibility to novelists, including some veteran novelists, or print journalists. That leaves historians.

\section{The Guild Stirs}

In the early 1990s, Rudy Kousbroek argued that a social discussion on the final years of the colony had been going on for 25 years, but the group who remained silent were historians, hidden behind "scrupulous neutrality."214 This was not quite accurate. As we have seen, historians like Jan Bank had produced carefully researched monographs, focused on politics and diplomacy. In 1988, another outstanding monograph was published, marking a new, international approach.

\section{J.J.P. de Jong}

Joop de Jong was the head of the Indonesia division at the Ministry of Foreign Affairs in The Hague. For years, he spent his free time working on

209 Ingrid Harms, "Veteranen oog in oog met hun Indië verleden," Vrij Nederland, 5 August 1995. 210 Pierre Heijboer, "Neerknallen van gevangen peloppers was normaal: Indië-veteranen vertellen in film over moorden," De Volkskrant, 5 August 1995.

211 Pieter Kottman, "Het kleine verschil tussen pijnlijk en hartverscheurend," NRC Handelsblad, 16 August 1995 .

212 "Koloniale oorlog 1945-1949. Gewenst en ongewenst beeld," Museum of the Resistance, Amsterdam, 26 November 2015-3 April 2016.

213 Chris Vos, "Televisie is niet debet aan verdringen van oorlogsmisdaden," NRC Handelsblad, 3о May 1994.

214 Rudy Kousbroek, "De diachronie van de doofpot," NRC Handelsblad, 29 April 1994; see also Kousbroek, Oostindisch Kampsyndroom, 287. 
a PhD dissertation, analysing the web of negotiations between the various stakeholders in the run up to the first "police action." Its publication met with a positive reception. As the reviewer in the NRC Handelsblad put it, De Jong had studied the 7,500 pages of the mammoth Officiële Bescheiden betreffende de Nederlands-Indonesische Betrekkingen 1945-1950, explored archives in four countries, interviewed 34 Indonesian nationalists and produced a "historical tour de force" of 300,000 words that, despite being "brilliant," also tended to put one to sleep. ${ }^{215}$

De Jong attacked foreign historians for tending to see the Dutch as intent on a war of colonial reconquest. He claimed the Dutch objective was never to reinstitute colonial authority. ${ }^{216}$ De Jong argued that many shared responsibility for the outbreak of violence. For instance, Japanese inaction and a number of British errors by September 1945 (71-85). During the years from 1945 to 1947 , the Dutch made mistakes, but also showed a willingness to compromise (211-214). However, the arrival of large numbers of Dutch troops from 1946 onward aggravated a dualism in Dutch policy, with the militant wing of the Catholic People's Party (KVP), together with the military leadership opposed to the leadership of Van Mook in Batavia (250-253). Party politics within the coalition government led to "cloak and dagger" scenes in The Hague (289).

De Jong argued that the Dutch went to great lengths to avoid the outbreak of warfare in the summer of 1947 (383-400). He concluded that British policy in India was no better than Dutch policy in Indonesia, as British policy amounted to the abandonment of India while the Dutch refused to abandon their colony, due to a sense of duty (410-411). In his concluding remarks, he maintained that the discussion between the Netherlands and the Republic of Indonesia of 1945-1949 was "purely about the manner in which decolonization would take place" (423-424).

De Jong referred to the years from 1945 to 1949 as "a discussion," unremembering that it was a war (423). His representation of the years from 1945 to 1947 offered a tapestry of intricate negotiations between a variety of actors - diplomats, politicians, military leaders, revolutionists. His greatest innovation was to complicate the representation by revealing how the British, Indonesians, Japanese, Americans and Dutch were entangled in a web of mutual responses. Furthermore, despite the best intentions of Dutch diplomats in Batavia and nationalist leaders

215 Michiel Hegener, "Nakaarten over de boedelscheiding in de Oost," NRC Handelsblad, 14 January 1989.

216 De Jong, Diplomatie, 10, 116. 
of Yogyakarta, peace was sabotaged by politicians in The Hague and revolutionary cadres. All would have been well, according to the diplomat De Jong, had politicians, soldiers and revolutionaries not interfered with the work of the diplomats.

As a histoir événementielle, De Jong's minute examination of two years of negotiations never reveals what motivated the Indonesian revolutionaries. The reviewer in Trouw summarized De Jong's thesis: negotiators failed to achieve a settlement because of the "force fields" behind both sides. ${ }^{217}$ The reviewer never questioned what motivated these force fields. Het Parool summarized de Jong's thesis as being that the outbreak of war was the result of a series of unfortunate blunders by the Dutch, English (sic) and Americans. ${ }^{218}$ The Marxist Joop Morriën argued that one can never narrate the true course of events by giving an almost day-to-day account, for something is always missing. ${ }^{219} \mathrm{P}$.J. Drooglever praised De Jong's "outstanding book" while criticizing De Jong for "exaggerating the impact of policy deeds and underestimating 'la forces des choses.'”22o De Volkskrant claimed that the red thread running though the book was the powerlessness of the well-intentioned Dutch and Indonesian negotiators who tried to reach a diplomatic solution. ${ }^{221}$ However, Jan Bank wrote of how he missed any account of the political behaviour of collectives and organizations in De Jong's account, adding that De Jong's constant criticism of politicians in The Hague betrayed a lack of compassion. ${ }^{222}$ Somehow, all of these commentators miss another shortcoming of De Jong's work. As Anne-Lot Hoek has argued, rather than analyse the fighting that constitutes a war, "academics preferred to focus on safer issues like the politics of decolonisation." ${ }^{223}$ De Jong's representation of a war of decolonization lacked the essential aspect of a war - the act of killing.

217 “'Achterbannen' in Nederland en Indonesië wilden geweld," Trouw, 2 June 1988.

218 Harm van den Berg, "Vele blunders brachten Nederland in koloniale oorlog," Het Parool, 2 June 1988.

219 Joop Morriën, “Koloniale oorlog ging voor diplomatie tegen Indonesië," De Waarheid, 3 December 1988.

220 Drooglever, review of Diplomatie, 310, 309.

221 "Promovenus signaleert onmacht politici: 'Rol Britten in Indonesische revolutie sterk onderschat," De Volkskrant, 2 June 1988.

222 Jan Bank, "In het web van dekolonisatie," De Volkskrant, 3 September 1988.

223 Anne-Lot Hoek, “Rengat, 1949 (Part 2)," Inside Indonesia 125, 12 September 2016, https:// www.insideindonesia.org/rengat-1949-part-2, accessed 27 February 2021. 


\section{P.M.H. Groen}

In 1987, Petra Groen co-edited a volume of essays on the Dutch "police actions." With one exception, none of the essays dealt with actual fighting. ${ }^{224}$ Groen, together with J. Zwaan, published a photographic book on the war of decolonization in 1989. The collection included images of Dutch soldiers in action as well as photographs of Dutch soldiers with Indonesian prisoners. ${ }^{225}$ Of the 166 photographs in the collection, only one showed a dead body (50). Four showed Dutch soldiers shooting, but the targets are invisible (30, 35, 36,39 ). The only photograph showing physical contact between a Dutch and Indonesian soldier, showed the former giving first aid to the latter (37). The collection continued the tradition of representing war without warfare.

In 1992 Groen co-wrote Inzet in Nederlands-Indië 1945-1950. It gave an account of the measures taken by the Dutch to suppress Indonesian nationalism, arguing that the Japanese used the nationalist leaders for their own ends. ${ }^{226}$ Groen and Staat admitted that the Dutch used contra-guerrilla warfare, which meant using hard methods against those unwilling to cooperate. Then they repeat, almost word for word, a sentence from Groen's $1991 \mathrm{PhD}$ dissertation, that members of the special forces and intelligence services did not shrink from using excessive violence (45). A photograph of the "notorious" Captain Westerling is included (48). This suggests that the only victims of Dutch hard methods were those who refused to cooperate and that the violence had not been indiscriminate. It also suggested that the use of excessive violence was the monopoly of Westerling's special forces and the intelligence services.

The authors mentioned that Dutch soldiers visited "native prostitutes," but pregnancies, children and sexually transmitted diseases were passed over in silence (53). They pointed out that veterans were not supported sufficiently when they returned to civilian life and that the population paid little attention to their stories (62). They did not point out that historians ignored the veterans, too. They added that veterans today are disturbed by talk of violent excesses (64).

Groen's most significant work, the result of years of archival research, was her $1991 \mathrm{PhD}$ dissertation. In her introduction, she argued that the historiography of the conflict had created a paradox - on the one hand, many veterans of the forgotten army had written memoirs based on their 
experience in the field, while, on the other hand, professional scholars (i.e. the historical guild) had all but ignored the military aspect of the conflict. For decades historians had focused exclusively on the political and diplomatic aspects of the conflict. ${ }^{227}$ She hoped to rectify this.

It was a brilliant piece of work, providing in-depth analysis of Dutch military strategic policy during the war. Thoroughly researched and closely argued, it offered a compelling thesis, that the military leadership under Spoor, blind to the strength of the nationalist movement, produced a strategic policy that was no more than "a castle in the sky" (289). What had permitted Spoor to follow this catastrophic policy had been the increased influence of the Catholic party in the Dutch coalition cabinet $(272,276)$. She provided evidence that the military leadership as well as the right-wing politicians had vastly underestimated the depth of support among ordinary Indonesians for the nationalist cause. ${ }^{228}$ This was combined with a vast overestimation of their own military offensive capacity (233-136).

Groen's focus was Dutch military strategy, but she also used Indonesian sources and occasionally focused attention on nationalist planning, motivations and actions (189-199). She made a partial attempt to measure the numbers killed during the final year of the conflict, including Indonesian victims (259-26o). Her work was the first of its kind, and punctured a number of myths. Her outstanding achievement had been to make it no longer possible to believe that the Dutch had lost their colony to a small pro-Japanese clique simply because their allies and the United Nations had betrayed them. Furthermore, she showed that the Dutch aim in 1945 was to reconquer their colony totally and liquidate the Indonesian republic. Only gradually, during 1946, did The Hague compromise somewhat, but the aim remained a partial decolonization only (267-275).

We must remember that it had already been suggested in a radio programme in 1979, Daarwerd iets grootsch verricht, that Spoor had influenced the decision to wage war. Furthermore, Groen's focus was limited to analysing the creation, implementation and effect of military strategic planning. Logistics, statistics, maps, reports, discussions, and timelines - this book offered an outstanding representation of the business of warfare, but with little representation of the reality of war in the field. When Groen described war, it was in leaden prose: "During the Dutch breakthrough and advance, heavy fighting broke out in a number of places. The Indonesians always came out worst" (103) and "two Dutch combat groups in south-east Tapanoeli

227 Groen, Marsroutes, 11-12.

228 Ibid., 56, 74, 177, 184-185, 196-198, 200, 215, 233-236, 282-289. 
encountered [...] roadblocks and resistance. The last was overcome with air support" (188). Her account of the British assault on Surabaya in 1945, which cost the lives of thousands, consisted of a single sentence: "In Surabaya the $5^{\text {th }}$ Division and the remainder of the $49^{\text {th }}$ Brigade, supported by air forces, managed to take the city from the republicans, step by step" (41).

Trouillot has argued that the naming of a fact or the choosing of a term by historians is often disguised as an innocent act, but it is always a "narrative of power" that sets up a "field of power." ${ }^{229}$ By 1992, the term "war crimes" was commonly used by journalists. Groen studiously avoided it. Indeed, she avoided the term "war," preferring the neutral "conflict" and even "police action." Her discussion of the use of excessive violence is minimal. Groen upheld the rule, described by Scagliola as "avoid sweeping statements" and by Kousbroek as "scrupulous neutrality." Regarding the hypothesis that the Dutch engaged in a military contra-terror policy, Groen concluded: "Based on the available source material it cannot with certainty be proven if this hypothesis is correct," adding that research shows that "the KST [Korps Speciale Troepen (Special Troops Corps), special forces under Westerling] and the intelligence services did not shrink from using excessive violence, even against the civil population" (213). This is the sole, indirect, reference to Westerling. She admitted that commanders received orders to use "hard" methods, but added that "summary executions remained forbidden" (117). She exhibited no curiosity as to whether this rule was followed, reflecting an attitude that Kousbroek described - "typical Dutch formalism. [...] It was not what was asked. Why should we look further for injustice?"230

Groen argued that there "had never been a declaration of war." Although we use the term "colonial war" in the 1990s, at the time, the majority considered "police actions" to be appropriate. ${ }^{231}$ Groen seemed to be saying that "police actions" is a suitable term (it is the title of her book from 1987) but on the other hand, she (reluctantly) admitted that we can now use the term "colonial war." If we are allowed to apply the term "colonial war" retroactively, then why cannot we use the term "war crime" retroactively?

On television in 2015, Groen argued that the historian has to maintain a middle position between veterans and those who claim that war crimes were widespread. However, there is no logical reason why truth should be in the middle. Groen contradicted her own position, admitting that she realized 
that "in a scale larger than we actually thought, there had been, shall we say, violations of the laws of war, so, excessive violence or war crimes. ${ }^{232}$ In an article in 2013, Groen proposed that there was now a consensus among historians regarding "the violent character of the colonial state."233

This was a work clearly created from inside the guild. Groen was employed by the Historical Section of the Royal Netherlands Army (who owned the copyright of the book) and it was defended as a $\mathrm{PhD}$ thesis at the University of Leiden. Her doctoral advisor was Cess Fasseur. In her foreword, she thanked military historian H.L. Zwitzer and a variety of former military officers from the Dutch East Indies, including F. van der Veen and C.A. Heshusius. ${ }^{234}$ Zwitzer had attacked Loe de Jong in print. Heshusius had leaked the infamous Loe de Jong concept text. Van der Veen had written the contra-De Jong appendix. Groen herself had advised Loe de Jong to forgo using the term "war crimes" for reasons that could best be termed legalistic. ${ }^{235}$ She recommended that De Jong refrain from claiming that the Dutch widely used excessive violence, suggesting that more research was needed. ${ }^{236}$

Groen claimed that she is the type of historian "who wants to stay close to the facts" and rejects "psychological speculating," adding: "The fact that I did my doctorate with Cees Fasseur maybe plays a role in that." ${ }^{237}$ In the 2015 television interview, Groen admitted that she changed her opinion. Her study of thousands of egodocuments from the time and her realization that oral history has value, led to a reassessment. She now concludes that official documents do not reveal the whole truth. Yet Marsroutes en Dwaalsporen was based on official documents.

This devotion to documents and deliberate avoidance of entanglement with political controversies meant that the best work being produced had little to contribute to collective remembering. It is an example of what Said termed "the powerful cult of professional expertise," the attitude that "you are responsible not so much to an audience in your community or society, as to and for your corporate guild of fellow experts." ${ }^{238}$ It supports Trouillot's argument: "The traditions of the guild, reinforced by a positivist

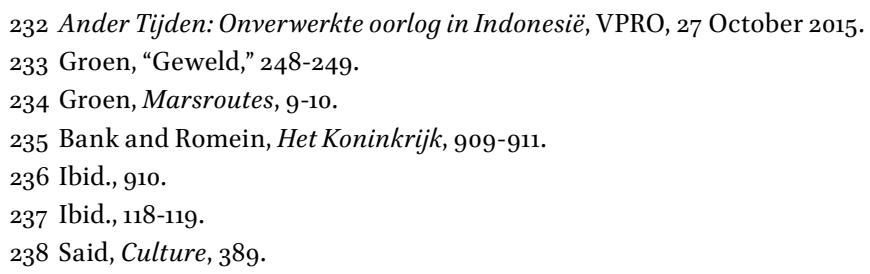


philosophy of history, forbid academic historians to position themselves regarding the present." ${ }^{239}$

Experts within the guild's circle of esteem were pleased with Groen's work. P. Kamphuis had supported Groen during her research. ${ }^{240}$ He now claimed that the top management of the Dutch army "cheered on" her work. ${ }^{241}$ Joop de Jong praised the work as a "powerful, balanced study."242 Jaap de Moor referred to it as "an excellent study."243 De Moor, like Groen, was working on a PhD on the Indonesian War of Independence at the University of Leiden. Indeed, he had contributed an essay to the 1987 collection that had been co-edited by Petra Groen. The circle of esteem was tight.

Veterans who were disturbed by talk of violent excesses had little to fear from the works of Groen. ${ }^{244}$ She had done an excellent job of demythologizing aspects of the war. It would be more difficult to argue that the army had been restoring peace and order, but as we already saw in the works of Laurens and De Graaff, many veterans had already concluded that they had fought in a dirty war, on the wrong side of history. Marsroutes en Dwaalsporen appealed to the guild of historians because of its vast research in the archives and ocean of facts supported by thousands of footnotes. But it left the experience of warfare unremembered and the thorny issue of war crimes excluded from scholarly consideration.

\section{A. Alberts}

A. Alberts' $195^{2}$ collection De eilanden (The islands) is a masterpiece of twentieth-century Dutch literature, each story saturated with a pyschogeography in which European restlessness and the hunger to conquer prove fatal. The stories indirectly touch upon decolonization. "De jacht" ("The hunt"), for instance, has the civil servant narrator claim that Indonesian revolts are always led by lunatics, "little messiahs." ${ }^{245}$ In this fable, Alberts represented colonialism as a matter of measuring, organizing and surveying.

239 Trouillot, Silencing the Past, 151.

240 Groen, Marsroutes, 9.

241 P.H. Kampenhuis, "Defensie schrijft historici niets voor," NRC Handelsblad, 21 May 1993.

242 Joop de Jong, “Mythe van 'verraden' leger in Nederlands-Indië doorgeprikt," De Volkskrant, 25 May 1991.

243 J.A. de Moor, “P.M.H. Groen, Marsroutes en Dwaalsporen. Het Nederlands militair-strategisch beleid in Indonesië 1945-1950" [review], Indonesia 55 (April 1993): 151-152.

244 See, for instance, the review written by East Indies veteran P. van Gelderen, "Het onverwerkt Indisch verleden," Leeuwarder Courant, 20 March 1991.

245 Alberts, Romans en verhalen, 64. 
The rebel is doomed because the government uses maps, timepieces and reason to pin him down and kill him. However, as Alberts' biographer, Graa Boomsma, pointed out, "De jacht" is set during the first weeks of the Japanese invasion of 1942. ${ }^{246}$ This casts a new light on the story. Alberts was saying that the Dutch system of control and exploitation, based on surveillance, measurement, repression and punishment, was about to be swept away.

Alberts remained obsessed with the memory of his life in the East Indies and his time in Japanese internment camps. ${ }^{247}$ Boomsma's research revealed that Alberts' contributions to De Groene Amsterdammer during the 1950 os and 1960 s form a consistent critique of Dutch historical indifference and ignorance and the common misunderstanding that Sukarno had been a Japanese fascist collaborator. ${ }^{248}$ In 1962, Alberts published a modest memoir of his years in the East Indies, expressing his affection for the landscape and people of Madura, "the most beautiful island in the world." ${ }^{49} \mathrm{~A}$ polemic concerning conditions for Europeans in the Japanese internment camps broke out between Rudy Kousbroek and novelist Jeroen Brouwers in the early 1980 s, followed immediately by the Loe de Jong controversy. This formed the background to Alberts returning, at an elderly age, to the meaning of decolonization. ${ }^{250}$

Een kolonie is ook maar een mens (A colony is only a human) appeared in 1989. Alberts argued that any comparison between Japanese internment camps and German concentration camps was absurd. ${ }^{251}$ Rejecting the view that the Dutch achieved something great in their colony, he also denied any need for an apology, because "a colony is also human" (7). He argued that the Dutch believed they were following an ethical policy in their colony. Nevertheless, the problem was rule by a foreigner, something that Indonesians rightfully resisted (33-35). When the Japanese invaded, Alberts viewed them as if they came from another planet, but he now recognized that the Dutch were the real aliens in Indonesia (71-72). Alberts claimed that Sukarno liberated his country (122-124).

In 1992 the organization Collective Promotion for the Dutch Book, which had published Hella Haasse's Oeroeg in 1948, commissioned Alberts to write a volume to celebrate Book Week. In Twee jaargetijden minder (Two seasons less), he suggested that, 5 o years after the Japanese invasion and the

\footnotetext{
246 Boomsma, Leven, 195.

247 Ibid., 113.

248 Ibid., 147-175.

249 Alberts, Namen Noemen, 46-69.

250 Boomsma, Leven, 111-113, 167.

251 Alberts, Een kolonie, 5-6.
} 
effectual end of the colony, there are still those who believe that the average Indonesian peasant was lazy and needed the supervision of the Dutch in order to work harder. ${ }^{252}$ Alberts argued that the Dutch aimed at turning a profit for Dutch industry, which led to forced labour and punishment for the Indonesian peasant. ${ }^{253} \mathrm{He}$ argued against reducing the history of colonialism to stereotypes, like the Orientalist image of the native servant, or the "impenetrable Eastern soul," so popular among colonial representations. ${ }^{254}$ Instead, he admitted that the time of colonialism is over, that all that is left is memories. ${ }^{255}$

Alberts' late works, written during a time of fiercely polemical discourse, provided a working through of the loss of the Dutch East Indies, going beyond the nostalgia of Dermoût and Nieuwenhuys. Alberts held a mirror to what the relationship between the ruler and the ruled had been, and found much wanting. The end - decolonization - approaches with the certainty of a Greek tragedy. Kousbroek saw this tragic element in Alberts' representation of decolonization. To be born into the colonial elite is fate. Consequently, to experience loss and exile is also fate. The Indisch community, the Indonesians and the Dutch are participants in a blind process. Those who experienced the old days retain memories, but it makes no sense to play the role of the victim. ${ }^{256}$

\section{J.A.A. van Doorn}

J.A.A. van Doorn had co-authored the first important study of Dutch violent excesses. In the coming decades, the sociologist continued to produce works on Dutch colonialism in the East Indies. In 1994, his study of decolonization, De laatste eeuw van Indië (The last century of the Dutch East Indies), was published.

In the introduction, Van Doorn offered remarks on Eurocentric and Indocentric approaches to colonial history. He criticized foreign historians because they refused to see the "problematic sides of an Indocentric perspective," namely, that "native society was [...] characterized by stagnation and passivity, unless colonial impulses were active." ${ }^{257}$ Furthermore, taking an Indocentric approach was impossible because the sources were

252 Alberts, Twee jaargetijden, 25.

253 Ibid., 30-32.

254 Ibid., 45 .

255 Ibid., 54 .

256 Kousbroek, Oostindisch Kampsyndroom, 362-363, 420.

257 Van Doorn, De laatste eeuw, 14. 
overwhelmingly Dutch. This was convenient for Van Doorn; he admitted his knowledge of Indonesian languages was close to nil, allowing him to "choose in this book for a conscious and consistent Eurocentric perspective" (15). What De Kadt had described in 1949 as "Dutch smugness" was alive and well in Dutch academia.

Van Doorn argued that the Dutch had "sailed a reasonable course" during decolonization (262). They ruled over a "model colony" and were set on organizing a gradual decolonization process. Alas, it ended in a debacle. The reasons, Van Doorn asserted, were the inflexibility of the Indonesian republic and the lack of support among the Indonesian intelligentsia for Dutch proposals, the inadequacy of the Dutch military, the pressure from the international community and the pressure of decolonization elsewhere in Asia. Finally, he blamed the increasing interference (bemoeienis) by the United Nations (262-263). Foreigners got it wrong twice - interfering during the war and later supporting an Indocentric historiography.

The great contribution of Van Doorn's sociological approach was that is counterpoised the approach taken by De Jong and Groen, who focused on events and the actions of individual actors. Van Doorn showed that personalities counted for little. Instead, he argued that individuals operated within a pre-World War Two colonial framework, which exposed their inadequacies after the Japanese occupation (264-284). Finally, he argued that the afterlife of decolonization had led to the Indisch repatriates and veterans being beleaguered by a new, anti-colonial generation, but during the 1980s, they had won respect and gained self-confidence (326-327).

The shortcomings of his approach are self-evident - a lack of Indonesian sources, a superficial account of the rise of Indonesian nationalism and a top-down approach to analysing colonial organization that ignored "a long tradition of hidden and open resistance by the native population." ${ }^{25} 8$

Locher-Scholten was motivated by Van Doorn's book to pen a reflective article entitled "Dutch East Indies and the Collective Memory." ${ }^{259}$ She recognized that having once felt pain for losing the East Indies, a large part of the Dutch public now felt shame. This polarization of emotions repressed the historical reality. She noted that in the past quarter of a century, exdetainees of Japanese camps as well veterans of the decolonization war and Moluccan activists all contributed to bringing the memory of decolonization to public attention. She argued that historians can help with the working 
through of the trauma, adding that Van Doorn's study should be seen as a contribution to that process.

\section{Ad van Liempt}

In 1994, Ad van Liempt offered a blow-by-blow account of Dutch negotiating in the final seven weeks before the first "police action" in 1947, covering much the same material that De Jong and Groen had provided in their works. Een mooi woord voor oorlog (A nice word for war), however, differed in style. Van Liempt did not use reference notes, because they lead to a "cumbersome interruption of the story." ${ }^{260} \mathrm{He}$ was not afraid to inject ironic asides, anecdotes and personal commentary. Most of all, what differentiated his work from the monographs of professional historians is the pace. Van Liempt leads the reader through every day of the seven weeks building up to war, with generous quotations from diaries, letters, minutes of meetings and interviews with some of the major players. The result is dramatic, reading like the screenplay of a film. Indeed, it would eventually form the basis for a television drama.

Despite lacking references, Van Liempt was at pains to impress upon the reader that he had done his homework. He claims to have consulted the private archives of nearly all of the prominent leaders. ${ }^{261}$ But "all" referred exclusively to Dutch leaders - no Indonesian archives were consulted. He frequently referred to the ninth volume of the Officiële Bescheiden, which De Jong had already thoroughly analysed. The anecdotal asides give the impression that one is encountering new revelations. We read a lot about secret documents and dossiers in archives, though these usually turn out to have been published in the Officiële Bescheiden. One such revelation is that in July 1947 General Spoor, discovering that the Dutch government had postponed his planned military assault, sent to his superiors his letter of resignation, which they refused to accept. Van Liempt believed this was a crucial move by Spoor in his attempt to ignite a war. Van Liempt described the telegram of resignation: "Telegram GB 303. Top Secret." This gives the impression that Van Liempt had seen a top-secret document, but the lack of reference notes makes this difficult to verify. He added, "all the parties succeeded in managing to keep Spoor's threat out of public view, right up until today." ${ }^{262}$ This is only half-true, for one can find the telegram in volume 
nine of the Officiële Bescheiden. ${ }^{263}$ Moreover, Joop de Jong had mentioned Spoor's threat of resignation back in $1988 .{ }^{264}$ Therefore, Van Liempt's quip, "right up until today" seems an exaggeration, especially when we find De Jong's book in Van Liempt's short bibliography and he references De Jong once directly. ${ }^{265}$

Furthermore, in 2012 Van Liempt published Nederland Valt Aan (The Netherlands attacks). It was meant to be a revision of Een mooi word voor oorlog. In fact, the new work differed little from the 1994 book, except for the title. The title corresponds with a television drama that Van Liempt directed, based on his 1994 work. The change of title seems to have been a commercial decision, repackaging an old book between new covers. However, if we go to the section in the "new" book describing Spoor's resignation, we find two changes. Firstly, there is a reference note to the Officiële Bescheiden. Secondly, Van Liempt's questionable claim that this remained hidden until his revelation has been deleted. ${ }^{266}$

Upon its publication in 1994, De Volkskrant ran a front-page article, wrongly claiming that the work, based on original archival research, revealed secrets never known before about Spoor's role bringing about the war. ${ }^{267}$ Max Palm called it "an intriguing book" that showed the Dutch leaders to be an unheroic bunch. ${ }^{268}$ However, H.L. Zwitzer attacked Van Liempt's simplifications and use of the "'good guys' and 'bad guys' procedure." Zwitzer criticized Van Liempt's cavalier use of sources. ${ }^{269}$ Months later, the NRC Handelsblad published another review, in which Paul Ophey praised how the book revealed the complicity of the press, especially De Volkskrant and Trouw, in bringing about the war. ${ }^{270}$ Van den Berg called the work an "outstanding, well-written account" based on sources that had been kept secret. He added, that of course historians would attack Van Liempt for

263 "Legercommandant (Spoor) aan chef generale staf Koninklijke Landmacht (Kruls) en verbindingsofficier bij het cabinet van her minister-president (Moolenburgh) 15 juli, 1947." ("Army Commander (Spoor) to Chief of General Staff of Royal Land Forces (Kruls) and Cabinet Liaison Officer of Prime Minister (Moolenburg), 15 July 1947,") in Wal et al., Officiële Bescheiden, vol. 9,683 .

264 De Jong, Diplomatie, 396.

265 Van Liempt, Een mooi, 18.

266 Van Liempt, Nederland Valt Aan, 247-248.

267 Jan Tromp, “Generaal Spoor wilde wat het kost oorlog in Indië," De Volkskrant, 18 May 1995. 268 Max Palm, "Indië verloren, rampsspoed geboren," NRC Handelsblad, 10 June 1994.

269 H.L. Zwitzer, "Indië conflict versimpeld," NRC Handelsblad, 18 June 1994.

270 Paul Ophey, "Pers en politionele acties," NRC Handelsblad, 1 January 1995. 
his arbitrary quoting from sources. ${ }^{271}$ In the same newspaper, Jan Greven called it "a conceited book" in which the author reduced the events to a good versus evil drama. ${ }^{272}$

1995

The release of the film Oeroeg, and the Boomsma and Princen affairs, had extended a public debate that had commenced with the Loe de Jong affair. With the $5^{\text {th }}$ anniversary of Sukarno and Hatta's Declaration of Independence approaching, 1995 seemed destined to be a year of further memory wars. Furthermore, it was planned for Queen Beatrix to visit Indonesia in August.

As already discussed, 1995 marked the end of the Boomsma trial, the publication of two of De Graaff's books, the broadcasting of De Excessen van Rawagedeh on television and the release of Tabee Toean in cinemas. The year began with the contested memory war showing no signs of abating. Let us look at a small sample of newspaper coverage over a period of two weeks in January. On 9 January, newspapers reported that Poncke Princen had returned to Indonesia. ${ }^{273}$ The following day De Volkskrant published articles on decolonization, including an interview with Princen, an article informing readers that parliamentary chairman Deetman had called for a political debate on decolonization, and an article from Herman Wigbold, complaining that politicians, not the media, were the ones who stifled debate. ${ }^{274}$ The next day the Algemeen Dagblad published an interview with Loe de Jong, who claimed it was pointless for the Netherlands now to offer an apology for what the country had done to Indonesia then. ${ }^{275}$ Trouw announced it was in favour of a national debate. ${ }^{276}$ The next day De Volkskrant reported that a majority of the population opposed having a national debate. ${ }^{277}$ The Leeuwarder Courant ran an interview with Minister Pronk, in which he stated

271 Joop van den Berg, "De zeven weken die aan de Politionele Actie voorafgingen," Trouw, 12 August 1994.

272 Jan Greven, “De Indische kwestie," Trouw, 1 October 1994.

273 “'Ik ben een shock-therapie': Poncke Princen gaat tevreden terug naar Indonesië," Trouw, 9 January 1995; “Poncke Princen bereid tot debat met veteranen," De Volkskrant, 9 January 1994; Edith van Zalinge, "Zuurkool eten en uren praten," Het Parool, 9 January 1995.

274 "Poncke Princen beschouwt visum als rehabilitatie," De Volkskrant, 10 January 1995; “Deetman bepleit politiek debat over Nederlands-Indië," De Volkskrant, 10 January 1995; Herman Wigbold, "Uitkomst van Indonesië debat staat nu al vast," De Volkskrant, 10 January 1995.

275 "Prof. de Jong: Excuses zijn overbodig," Algemeen Dagblad, 11 January 1995.

276 "Commentaar: oproep tot debat," Trouw, 11 January 1993.

277 “Meeste Nederlanders hoeven geen Indië debat," De Volkskrant, 12 January 1995. 
that the Dutch "police actions" had been "futile and wrong."278 On 13 January, NRC Handelsblad published an article opposing any national debate while Trouw warned that Minister Pronk wished for the government to issue a declaration that the Netherlands had fought a crude ("ordinaire") colonial war. ${ }^{279}$ The following day De Volkskrant ran nine letters to the editor on the issue of veterans and war crimes. ${ }^{280}$ The Leeuwarder Courant published an interview with the only still living member of the Dutch cabinet of 1947. In a separate article, Bob Kroon wrote that people in Indonesia regarded the Dutch as fools for considering an apology. ${ }^{281}$ Two days later, Elsbeth Locher-Scholten called for an end to the simplistic black versus white tone of the moral debate. ${ }^{282}$ Cees Fasseur wrote that the Netherlands made serious errors during decolonization, but pleaded for nuanced judgements. ${ }^{283} \mathrm{~A}$ businessman argued that a national debate on decolonization might have a negative impact on business with Indonesia. ${ }^{284} \mathrm{~A}$ couple of days later, newspapers announced that members of parliament had decided not to have a debate on decolonization. ${ }^{285}$ Joop de Jong shared his verdict, that the Netherlands "didn't do such a bad job." ${ }^{286}$ Het Parool dedicated a page to the work of Louis Zweers, who had uncovered photos of Dutch soldiers in action against Indonesian nationalists. ${ }^{287}$ Het Parool reported that the leader of the Green-Left party demanded a declaration that Dutch policy had been wrong. ${ }^{288}$ Throughout these weeks, every newspaper covered the Graa Boomsma affair in detail. With this memory war dividing society, it is no surprise to find historian Vincent Houben referring to the "torn soul" of

278 Paul Koopman, "Politionele acties fout en zinloos," Leeuwarder Courant, 12 January 1995. 279 J.L. Heldering, "Een exercitie in zelfkwelling," NRC Handelsblad, 13 January 1995; "Commentaar: Wijsheid achteraf," Trouw, 13 January 1995.

280 "Laat ons schoon schip maken met koloniale verleden," De Volkskrant, 14 January 1995.

281 Paul Koopman, "Mansholt in Indisch boetekleed," Leeuwarder Courant, 14 January 1995; Bob Kroon, "Batikhemd staat veel beter dan boetekleed," Leeuwarder Courant, 14 January 1995. 282 Elsbeth Locher-Scholten, "Moralisme helpt ons Indië niet verwerken," De Volkskrant, 16 January 1995 .

283 Cees Fasseur, "Historisch gelijk niet aan Nederlands kant," Het Parool, 16 January 1995. 284 Frans Peeters, "Debat over Indië heeft groot risico," Het Parool, 16 January 1995. 285 "Partijen willen geen debat over Indië," Leeuwarder Courant, 18 January 1995; "Fractieleiders: geen politiek Indië-debat," Trouw, 18 January 1995; “Geen kamerdebat over politionele acties Indonesië," Amigoe, 18 January 1995.

286 Joop de Jong, "Nederland deed het zo slecht nog niet in Indië," De Volkskrant, 21 January 1995. 287 Leonoor Wagenaar, "Keiharde fotos uit de frontline," Het Parool, 21 January 1995. 288 Willem van Toorn, "Onze gemartelde bruid Indonesia," Het Parool, 23 January 1995. 
the Dutch. ${ }^{289}$ By mid-year, Jan Blokker concluded that decolonization had become a channel for national narcissism. ${ }^{290}$

Ted Schouten's book Dwaalsporen: Oorlogsmisdaden in Nederlands-Indië (Stray tracks: War crimes in the Dutch East Indies) offered little new, being based on published cases. His work was indebted to the Excessennota of 1969 and to Groen's work. He wrote of "terrorists" being killed in South Celebes. ${ }^{291}$ He argued that the Dutch contra-guerrilla war was due to widespread use of terror by the Indonesians (121-123). Dutch atrocities were listed without comment (123-132, 150-161). The number of victims of the Rawagede massacre was wrongly listed as 150 (150). Schouten claimed that the Indonesians manufactured incidents as propaganda for the international community (131-132). With no references, thin on analysis and lacking any conclusion, the book had been put together in haste. Interestingly, the title refers to war crimes, but not Dutch war crimes as such. The implication was that the Dutch did behave badly, but the Indonesians behaved even worse. That such a book could reach publication highlighted that a serious study of Dutch war crimes was needed, but none was forthcoming.

In March, De Volkskrant gave a short overview of historical titles published, or to be published, in this anniversary year (as in, end of World War Two). The list included 46 books on World War Two in the Netherlands, but only ten titles with a connection to the "liberation" of Indonesia. ${ }^{292}$ Of these ten, none provided direct analysis of the war of decolonization. For instance, Harry Poeze and Henk Schulte Nordholt's De roep om Merdeka (The call for freedom) had a promising title, but was in fact an anthology of 37 short Indonesian essays, poems, stories, speeches and pamphlets calling for freedom. ${ }^{293} \mathrm{~A}$ useful collection, but not a deep analysis of decolonization.

Another was the nineteenth volume of Officiële Bescheiden betreffende de Nederlands-Indonesische Betrekkingen. Since the death of S.L. van der Wal, the work had been under the editorship of P.J. Drooglever and M.J. Schouten and the final, $20^{\text {th }}$ volume appeared in 1996. Its origin was inextricably linked with the Hueting interview of 1969 and the publication of the Excessennota (republished in 1995, with an introduction by historian Jan Bank). In its finished form, it was a monumental work: 7,00o official Dutch government documents and 15,000 pages. The final volume, according to

289 Houben, “A Torn Soul," 47-66.

290 Jan Blokker, "Kanaliseering van een nationaal narcisme," De Volkskrant, 12 August 1995.

291 Schouten, Dwaalsporen, 99-101.

292 "Etalage," De Volkskrant, 18 March 1995.

293 Poeze and Schulte Nordholt, De roep. 
one reviewer "reads like an exciting novel." ${ }^{294}$ Rereading the entire work, Drooglever concluded that the documents revealed that the Dutch of 1945 were "rock solid convinced" that Indonesia, would remain dependant on the Netherlands. Dutch nationalism, concern for their own status and business interests, and a strong sense of mission, were forces that shaped Dutch policy. ${ }^{295}$

During his life, Raymond Westerling dreamed of becoming an opera star. In 1995, he became the main character in a chamber opera. The author of the libretto of Westerling was Graa Boomsma. His purpose was to complicate the simplistic narrative by focusing on the perpetrator rather than the victim and to leave the audience disturbed. ${ }^{296}$ The chamber opera premiered in Amsterdam in June and ran for four evenings. Reviews were positive, agreeing that, by revealing the human rather than the hero, the work offered a sympathetic portrayal of a man who, far from being simply a brute, had been the tragic plaything of political and military powers. ${ }^{297}$

The most interesting historical publication of 1995 came from journalist Remco Meijer, a collection of eighteen interviews with leading participants in the debate on decolonization. It did have blind spots. Of the eighteen, just two were women. Seven interviewees were totoks, but none were Indos. Three interviewees are veterans, but none could be considered a spokesperson for the veteran platform. ${ }^{298}$ None were from the KNIL. None were Moluccan. None were Indonesian.

One concern that emerges from the historians is their annoyance with non-academics. Jan Bank expressed frustration that Van Liempt's work made the front page in De Volkskrant. ${ }^{299}$ (He doesn't mention that Groen's work had made the front page in Trouw. ${ }^{300}$ ) Groen attacked Van Liempt's work for as being simplistic. ${ }^{301}$ Boomsma, on the other hand, praised Van

294 Meijer, review of Officiële Bescheiden, 454.

295 Drooglever, "Dekolonisatie," 466.

296 Cornald Maas, "Al is het maar stil in ieders hoofd," De Volkskrant, 2 June 1995.

297 Hans Visser, "Sympathiek ondanks al dat bloed op Celebes," Provinciale Zeeuwse Courant, 3 June 1995; Reinjan Mulder, "Het leven van kapitein Westerling in een opera," NRC Handelsblad, 7 June 1995; Johan Jansen van Galen, "Requiem voor een desperado," Het Parool, 6 June 1995; Peter van der Lint, "Indië zingesprekken," Trouw, 10 June 1995; Frits van der Waa, "Opera Westerling mist conflict," De Volkskrant, 10 June 1995.

298 For instance: "My condescension for the so-called veterans, and by that I mean those whiners, dates from the time of my military service," J.E. Hueting interviewed in Meijer, Oostindisch, 55 . 299 Interviewed in ibid., 82.

300 "Politiek liet militairen in Indonesië beleid maken," Trouw, 28 February 1991. 301 Interviewed in Meijer, Oostindisch, 119. 
Liempt's work. ${ }^{302}$ Ewald Vanvugt earned the ire of two historians - Fasseur called him "a failed writer" and Van Goor exclaimed, "Vanvugt looks for the scandal and presents it as a discovery." ${ }^{\prime 03}$ However, Jos de Beus accurately pointed out that amateur historians had "pushed the professional guild into the defensive." ${ }^{304}$

Despite differences, the interviewees agreed that the nation was gripped by widespread moral indignation. Public debate had become polarized between contesting collective memories. On the one hand, veterans fighting for recognition, on the other, zealots crying "war crimes." The historians inhabit the uncomfortable middle ground - the sensible person who delves into the archives, producing balanced, evidence-based analysis. Bank admitted that great work had been accomplished by historians, but, "the results seem to not get through." ${ }^{305}$ Schulte Nordholt praised the work of Van Doorn, but wondered if it would be read. ${ }^{306}$ Henk Hofland conceded that historians produced outstanding studies, but what was lacking was "the really great generalist" - someone of the calibre of the great historian, Johan Huizinga. ${ }^{307}$

Outstanding monographs had appeared in the last few years, from Jan Bank, Joop de Jong and Petra Groen - but all were written for the circle of esteem within the guild. Such works seldom appeared in paperback. They had an afterlife; they were collected in academic libraries and footnoted in monographs, but they hardly impacted the wider community, remaining on the periphery of collective memory. It remained the works of Van Liempt and Van Dis that sold by the thousands. The 1960 s had commenced with the innovation of television. By the 1980 s, radio and television journalists had become the drivers narrating the history of decolonization. Newspapers paid them widespread attention, too. Despite this, historians, through discipline and careful methodology, had gained a deeper understanding of the complexities of decolonization. But historians found themselves in a dilemma. The contesting of memory taking place on radio, television and in newspapers had collapsed into a moral contest. Historians like Bank, Locher-Scholten, Joop de Jong and Fassuer attempted to insert reasoned argument and complexity

302 Interviewed in ibid., 177.

303 Fasseur interviewed in ibid., 105; Van Goor interviewed in ibid., 128.

304 De Beus, "God dekoloniseert niet," 320.

305 Interviewed in Meijer, Oostindisch, 86.

306 Interviewed in ibid., 139.

307 Interviewed in ibid., 171. 
into public discourse, but they lacked the privileged position that Loe de Jong had had in the early 1960 s. To be heard, they would have to find a new Huizinga.

Many Dutch newspapers marked the $50^{\text {th }}$ anniversary of the Declaration of Independence in August 1995. The Haagsche Courant published a supplement on the topic, including an interview with a former member of the KNIL entitled "My War Is Not Finished." ${ }^{308}$ He told the journalist how he had seen terrible things: "[P]eople shouldn't accuse us of war crimes. What we did was simply a reaction to the actions of the Indonesians." He concluded: "just like the Dutch who fought against the Germans, we fought for the same queen, the same flag and the same ideals." The supplement included a profile of one of the 25,000 volunteers in the Dutch army. He told his interviewer: "I never talk about the Indies, mainly because no one ever listens." ${ }^{09}$ The title of the article, "The People Must Know Why," emphasized how veterans believed the government had betrayed them, but also the people and historians, who seemed disinterested.

A few days after the anniversary, Queen Beatrix arrived in Indonesia for an official state visit. The Dutch government, giving in to pressure from veteran groups, had timed her arrival so that she would not have to acknowledge 17 August as the day of Indonesian independence. At an official state dinner, the queen gave a speech that for months had been the source of controversy. Would she acknowledge that the Dutch had been on the wrong side of history? The queen had penned her own speech but had listened to the advice of three historians - Jan Bank, Henk Wesseling and Cees Fasseur. ${ }^{310}$ The speech, delivered in perfect English before General Suharto and Indonesian dignitaries, was broadcast live on Dutch television. ${ }^{31}$ The crucial sentence was: "When we look back at that time which now lies almost 50 years behind us, it deeply saddens us that so many died in that struggle or had to bear its scars for the rest of their lives." She had avoided recognizing that Indonesia had become a sovereign state on 17 August 1945. Likewise, she had avoided apologizing for Dutch wrongdoing. However, the Dutch head of state had expressed sadness for the lives lost and destroyed by the war of decolonization. The following day, Dutch newspapers reported that parliamentarians had been satisfied

308 Frank Hitzert, “Mijn Oorlog Is Niet Afgelopen," De Haagsche Courant, 12 August 1995. 309 John Stael, “De Mensen Moeten Weten Waarom," De Haagsche Courant, 12 August 1995. 310 Jan Tromp, “Beatrix ‘droevig' over littekens dekolonisatie," De Volkskrant, 22 August 1995; Fasseur, Dubbelspoor, 223.

311 It can be viewed on YouTube: https://www.youtube.com/watch?v=PQJ-qsTVSEs, accessed 27 February 2021. 
because her speech had been "balanced," a virtue held in high esteem by parliamentarians..$^{32}$ And, as we have seen, a virtue held in high esteem by Dutch historians.

\section{Bibliography}

Alberts, A. Een kolonie is ook maar een mens. Amsterdam: Van Oorschot, 1989.

Alberts, A. Namen Noemen: Zo maar wat ongewone en openhartige herinneringen aan het leven in het verloren paradijs, dat Nederlands-Indië heette 1939-1947. Amsterdam: H.J. Paris, 1962.

Alberts, A. Romans en verhalen. Amsterdam: G.A. van Oorschot, 2007 [1952].

Alberts, A. Twee jaargetijden minder. Amsterdam: G.A. van Oorschot, 1992.

Bank, Jan and P. Romein, eds. Het Koninkrijk der Nederlanden in de Tweede Wereldoorlog, vol. 14b, Reacties. The Hague: SDU, 1991.

Baudrillard, Jean. Simulacra and Simulation. Translated by Sheila Faria Glaser. Ann Arbor: University of Michigan Press, 1994 [1981].

Beus, Jos de. "God dekoloniseert niet: Een kritiek op de Nederlandse geschiedschrijving over de neergang van Nederlands-Indië en Nederlands Suriname.” BMGN - Low Countries Historical Review 116, no. 3 (2001): 307-324.

Boomsma, Graa. De laatse tyfoon. $3{ }^{\text {rd }}$ ed. Amsterdam: Van Gennep, 2012 [1992].

Boomsma, Graa. Leven op de rand: Biografie van A. Alberts. Amsterdam: Van Oorschot, 2017.

Bosma, Ulbe. Terug uit de Koloniën: Zestig jaar postkoloniale migranten en hun organisaties. Amsterdam: Bert Bakker, 2009.

Dis, Adriaan van. De Indië Boeken. Amsterdam: Augustus, 2012.

Dolle, Esther ten. "Morality is Another Story." Dutch Crossing 27, no. 2 (2003): 169-180.

Doorn, Jacques A.A. van. De laatste eeuw van Indië: Ontwikkeling en ondergang van een koloniaal project. Zutphen: Walburg Pers, 1994.

Drooglever, Pieter J. “Dekolonisatie in twintig delen: Een persoonlijke impressie.” BMGN - Low Countries Historical Review 111, no. 3 (1996): 464-472.

Drooglever, Pieter J. Review of Diplomatie of strijd. Een analyse van het Nederlands beleid tegenover de Indonesische revolutie 1945-1947, by J.J.P. de Jong. BMGN - Low Countries Historical Review 105, no. 2 (1990): 308-310.

312 "Troonrede in de tropen," NRC Handelsblad, 28 August 1995; "Kamer noemt rede vortin evenwichtig," Het Parool, 22 August 1995; "Staatsbezoek Indonesië op kousvoeten: Koningin Beatrix laat in tafelrede excuses over late erkenning onafhankelijkheid achterwege," Trouw, 22 August 1995; Jan Tromp, "Beatrix 'droevig' over littekens dekolonisatie," De Volkskrant, 22 August 1995 . 
Gennep, Arnold van. The Rites of Passage, trans. Monika B. Vizedom and Gabrielle

L. Caffee. London: Routledge, 1960 [1908].

Graaff, Anton P. de. Brieven uit het veld. Franeker: Van Wijnen, 1989.

Graaff, Anton P. de. De heren worden bedankt. Franeker: Van Wijnen, 1986.

Graaff, Anton P. de. De weg terug. Franeker: Van Wijnen, 1988.

Graaff, Anton P. de. Levenslang op patrouille. Franeker: Van Wijnen, 2000

Graaff, Anton P. de. Merdeka. Franeker: Van Wijnen, 1995.

Graaff, Anton P. de. Met de TNI op stap. Franeker: Van Wijnen, 1991.

Graaff, Anton P. de. Notities van een soldaat. Franeker: Van Wijnen, 1995.

Graaff, Anton P. de. Zeg, Hollands soldaat.... Franeker: Van Wijnen, 1995.

Groen, Petra M.H. "Geweld en geweten: Koloniale oorlogvoering en militaire ethiek in Nederlands-Indië, 1816-1941." Militaire Spectator 182, no. 5 (2013): 248-266.

Groen, Petra M.H. Marsroutes en Dwaalsporen: Het Nederlands militair-strategisch beleid in Indonesië 1945-1950. The Hague: Sdu, 1991.

Groen, Petra M.H. and D.W. Staat. Inzet in Nederlands-Indie 1945-1950. Amsterdam: Van Soeren and Co., 1992.

Houben, Vincent J. H. "A Torn Soul: The Dutch Public Discussion on the Colonial Past in 1995." Indonesia 63 (April 1997): 47-66.

Jong, Joop J.P. de. Diplomatie of strijd:Een analyse van het Nederlands beleid tegenover de Indonesische Revolutie. Amsterdam: Boom, 1988.

Junger, Sebastian. Tribe: On Homecoming and Belonging. New York and Boston: Twelve, 2016.

Kousbroek, Rudy. Het Oostindisch Kampsyndroom. Amsterdam: Olympus, 2005.

Laurens, Ben. De Vreet Patrouille. Rotterdam: Ad Donker, 1987.

Laurens, Ben. Het Peleton. Rotterdam: Ad Donker, 1986.

Liempt, Ad van. Een mooi woord voor oorlog: Ruzie, roddel en achterdocht op weg naar de Indonesië-oorlog. The Hague: Sdu, 1994.

Liempt, Ad van. Nederland Valt Aan: Op weg naar oorlog in Indonesië 1947. Amsterdam: Balans, 2012.

Lipkin, Steven N. Docudrama Performs the Past: Arenas of Argument in Films Based on True Stories. Newcastle upon Tyne: Cambridge Scholars Publishing, 2011.

Meijer, H. Review of Officiële Bescheiden betreffende de Nederlands-Indonesische Betrekkingen 1945-1950, vol. 20, by P.J. Drooglever and M.J.B. Schouten, BMGN - Low Countries Historical Review 113, no. 3 (1998): 454-455.

Meijer, Remco. Oost indisch doof: Het Nederlandse debat over de decolonisatie van Indonesië. Amsterdam: Bert Bakker, 1995.

Melief, Willem B.A.M. Evaluatie van de dienstverlening van "Stichting Dienstverlening Veteranen.” Utrecht: Verwey-Jonker Instituut, 1995. 
Mooij, Annet. “De Langste Schaduw: Het denken over psychische oorlogsgevolgen.” In Binnenskamers: Terugkeer en opvang na de Tweede Wereldoorlog-Besluitvorming, edited by Conny Kristel, 261-291. Amsterdam: Bert Bakker, 2002.

Moor, Jaap A. de. "Het Korps Speciale Troepen." In De Politionele Acties, edited by Ger Teitler and Petra M.H. Groen, 121-143. Amsterdam: De Bataafsche Leeuw, 1987. Oostindie, Gert. Soldaat in Indonesië 1945-1950: Getuigenissen van een oorlog aan de verkeerde kant van de geschiedenis. Amsterdam: Prometheus, 2015.

Pattynama, Pamela. "Cultural Memory and Indo-Dutch Identity Formations." In Post-Colonial Immigrants and Identity Formations in the Netherlands, edited by Ulbe Bosma, 175-192. Amsterdam: Amsterdam University Press, 2012.

Poeze, Harry and Henk Schulte Nordholt, eds. De roep om merdeka: Indonesische vrijheidslievende teksten uit de twintigste eeuw. Amsterdam: Mets/Novib, 1995.

Sars, Paul. Adriaan van Dis: De zandkastelen van je jeugd. Nijmegen: SUN, 1996.

Scagliola, Stef. “The Silences and Myths of a 'Dirty War': Coming to Terms with the Dutch-Indonesian Decolonization War (1945-1949)." European Review of History 14, no. 2 (2007): 235-262.

Schouten, Ted. Dwaalsporen: Oorlogsmisdaden in Nederlands-Indië. Zutphen: Alpha/Walburg Pers, 1995.

Smulders, Robert M. Een Stem uit her Veld:Herinneringen van Ritmeester-Adjuant van Generaal S. H. Spoor. Amsterdam: De Bataafsche Leeuw, 1988.

Trouillot, Michel-Rolph. Silencing the Past: Power and the Production of History. Boston: Beacon Press, 1995 .

Turner, Victor. Blazing the Trail: Way Marks in the Exploration of Symbols, edited by Edith Turner. Tucson and London: University of Arizona Press, 1992.

Turner, Victor. The Ritual Process: Structure and Anti-Structure. New York: Aldine de Gruyter, 1995 .

Turner, Victor and Edith Turner. Image and Pilgrimage in Christian Culture: Anthropological Perspectives. Oxford: Basil Blackwell, 1978.

Wal, Simon L. van der, Pieter J. Drooglever and Mieke J.B. Schouten. Officiële Bescheiden betreffende de Nederlands-Indonesische Betrekkingen 1945-1950. 20 vols. The Hague: Instituut voor Nederlandse Geschiedenis, 1971-1996.

Zwaan, Jacob and Petra M. H. Groen. Oorlog en verzet in Nederlands-Indië 1941-1949 en de voorlichting aan de na-oorlogse generaties. Amsterdam: De Bataafsche Leeuw, 1989.

\section{Television}

Ander Tijden: Onverwerkte oorlog in Indonesië. VPRO, 2015.

De Excessen in Rawagedeh. RTL 5, 1995.

De Kampong staat in brand. RVU, 1989. 
Oorlog en Verzet in Nederlands-Indië. RVU, 1989.

Tabee Toean: Op patrouille in 'Nederlands-Indië.' NCRV, 1996. [Released in cinemas in1995.]

De Tijd Staat Even Stil: De politionele acties. NCRV, 1993.

De Tijd Staat Even Stil: Poncke Princen. NCRV, 1994.

\section{Film}

Gordel van Smaragd. [1997]. Directed by Orlow Seunke. Universal Pictures (Benelux), 2004. DVD.

Max Havelaar. [1976]. Directed by Fons Rademakers. A-Film, 2008. DVD

Oeroeg. [1993]. Directed by Hans Hylkema. Woerden: Paramount Home Entertainment, 2005. DVD. 



\title{
8 Conclusion
}

\begin{abstract}
The press initially collaborated with the authorities by representing a sanitized war. Until the late 196os, the press exhibited indifference when it came to decolonization. With the Hueting interview of 1969, television, as well as radio, provided veterans a platform to represent their experiences. Literary works for the most part provided nostalgic memories of loss. However, Moluccan activists as well as postmemory novelists problematized unremembering during the 1970 and 1980 s. De Jong's work of the late 1980 s broke the silence of the historical guild. By the mid-199os the collective memory of decolonization had become highly contested. Today, with the legal courts writing history, historians seek to reclaim the initiative of undoing the decades of unremembering of previous generations.
\end{abstract}

Keywords: collective memory, Hueting interview, unremembering, decolonization, Dutch East Indies

The years from 1945 to 1995 saw various tendencies in Dutch culture in (un) remembering decolonization. Official media initially collaborated with military and governmental authorities by reporting a war that was not a war. The military authorities generated a fiction that represented the war as a massive humanitarian project. The fiction was distributed by a complicit press and consumed by a compliant public. This was further supported by the self-image of a benevolent Dutch power attacked by Japanese collaborators and betrayed by ignorant, interfering foreigners. Counter-memories were sidelined as extreme and unpatriotic. This non-critical approach was maintained for some time.

Nostalgic remembering served a pragmatic function, helping an Indisch identity to thrive in exile. This remembering was not entirely reactionary. It was not directed towards restoring colonial power, except by an archconservative fringe. Instead, nostalgia provoked a reflection upon what it meant to be Indisch, in an attempt to salvage a collective memory from

Doolan, P.M.M., Collective Memory and the Dutch East Indies. Unremembering Decolonization. Amsterdam: Amsterdam University Press 2021 DOI: $10.5117 / 9789463728744$ CHO8 
pre-war times. Nevertheless, this nostalgia was a form of unremembering as it eclipsed rather than confronted the pain of decolonization and failed to account for the historical rupture that was decolonization.

Throughout the 196os, the press, for the most part, exhibited passiveness and disinterest when it came to the war of decolonization. Reviewers of the film The Battle of Algiers demonstrated an unwillingness or a lack of imagination when it came to drawing parallels between the French in Algeria and the Dutch in Indonesia. Reviewers of Paul van 't Veer's De Atjeh-oorlog demonstrated a similar lack of imagination when it came to drawing parallels between the brutality of a Dutch war of colonial conquest and that of the war of decolonization.

However, the new medium of television provided a platform in which former conscripts, rather than political leaders or professional historians, stimulated a new discourse. Loe de Jong's early work on television helped to create the collective memory of the Dutch as plucky heroes in the face of German barbarism. The Hueting interview of 1969 clearly was a breakthrough. However, the official inquiry that followed and the massive project to publish official documents, furthered the process of unremembering. From the early 1970 on onward television, radio and newspapers allowed a minority of veterans to articulate memories of excessive violence.

Veterans also authored a variety of fictionalized memoirs that revealed the "dirty war" in all of its brutality. There was no cover-up. Ironically, the motivation for many veterans of "the forgotten army" was for their efforts to be remembered and acknowledged. They hoped to end their liminal existence by seeing their experience integrated into the collective memory of the nation. Instead, they were increasingly dismissed as war criminals.

Novelists provided fictional memoirs focusing on loss and nostalgic rememberings, but during the 1980 s, a second generation of postmemory novelists and political activists problematized the act of unremembering, sometimes highlighting the dilemmas of postcolonial hybridity. The postmemory violence of young Moluccans during the 1970s can best be understood as actions against unremembering.

Academic historians mainly avoided the topic. The virtues promoted by the guild included cultivating a balanced judgement, maintaining official, legalistic terminology, avoiding sweeping statements of any sort and refraining from speculation and the making of controversial claims. Hence, we find Dutch military historians at the centre of the guild in the 1990s maintaining the fiction that the war was a series of short "police actions." Postcolonial insights and methods had made few inroads among practitioners of Dutch colonial history by the mid-199os. 
New media in the form of television had democratized the debate from the late 196os onward. By the mid-199os, this had meant that decolonization had become a site for publically contested memories. Legal cases involving Loe de Jong, Graa Boomsma and Poncke Princen were widely covered in the media, leading to an increasingly polarized debate. Democratization confronted historians with a dilemma. Jan Bank, Joop de Jong and Petra Groen all participated at public events - exhibitions, readings, discussions and documentaries. Nevertheless, the new stridency of tone in the public debate was not something that scholars had been trained to deal with. If they did not emerge wholeheartedly from their circles of esteem, they ran the risk that they would be drowned out by the increasing cacophony of voices. Yet, the virtues of balance and avoiding sweeping statements would be in danger of being lost if they fully entered the fray.

In my view, the most important catalysts for undoing the work of unremembering came from documentary makers, like Joris Ivens, Herman Wigbold and Roelof Kiers, from veterans like Job Sytzen, Joop Hueting and Ben Laurens, from novelists like Beb Vuyk, Marion Bloem and Graa Boomsma. Despite some notable exceptions, historians lagged behind. The drivers for remembering decolonization were most often working outside the historical guild. Dutch historians contributed to unremembering the national past.

Imagine a man who, as a child, had been blinded by a disease. Decades pass, the man grows old, but a technological development allows a medical intervention that restores his sight. Throughout the passing years, the man's remembering nurtured the image of his youthful visage. Now he calls for a mirror. What he sees staring back at him is an alien scarred and wrinkled face. Perhaps he wishes himself blind again.

By 1995, the Dutch began to emerge from blindness and peer tentatively into the mirror. They had constructed a memory of themselves as an innocent and even righteous nation, one that had survived the mutilation of German occupation. For decades, a collective memory of themselves as the victims of German and Japanese occupations was sustained. It was difficult to see that the victim was simultaneously a perpetrator of injustice. Furthermore, Dutch "overseas history" had always been viewed as benevolent.

For many, what was reflected in the mirror was something alien. It was difficult to recognize the nation that had collaborated with military and political authorities in a brutal war of colonial reconquest. Perhaps some would have preferred to remain blind. Perhaps this explains my friends' reticence to peer in detail into the mirror during our student days in the early 1980 s. Stoking controversy was not the way of the historical guild. Strolling 
through the hallowed halls of a Dutch university in the early to mid-1980s, one was unlikely to encounter any hint of a dirty war fought in the recent past. My university days in Groningen (1982-1987) were marked by conversations more likely to revolve around the rising AIDS crisis rather than the rise of postcolonial theory. As the AIDs pandemic grew, colonial historians practised safe history. Decolonization remained off the curriculum.

Returning to my mirror metaphor, I imagine that the old man would have turned the mirror to the wall. If he were a king, like in a fairy story, he would have ordered all mirrors in the kingdom to be destroyed, all mirror makers put to death. But life is no fairy story. By 1995, there were too many mirrors in the Kingdom of the Netherlands. Destroying them was not an option. Silencing the historians, novelists, film-makers and documentarists was not an option. And of course, the internet was just making itself felt in people's lives. Soon, the historical guild would have to deal with a new, medium and an explosion of blogs and websites dealing with colonialism and its (un)rememberings.

We might expect that some sort of synthesis would emerge, creating a more complex collective memory. One that would accept the rights of the peoples of Indonesia to determine their own future without Dutch interference, but would also recognize the Indisch Dutch as being fully Dutch, with a colourful and interesting history to be fully embraced by the nation. One that would include facing up to the brutality of the war, while also acknowledging the suffering of the Dutch soldiers and the wrongs done to them. One that would integrate the Moluccan experience into the entangled narrative of Dutch colonialism and decolonization. There might have been the expectation that debates of the mid-199os would produce some sort of working through. However, history is a perpetual argument and the collective memory of decolonization remains contested.

Henk van den Doel's history of the war from 2000 was the first general study of the conflict since Loe de Jong. Based on Dutch sources, it did attempt to expand beyond the narrow Dutch perspective. ${ }^{1}$ Henk Schulte Nordholt set a new agenda by laying a significant connection between the violence of the war of decolonization and the violence of colonialism. ${ }^{2}$ In 2002, Stef Scagliola broke new ground with a courageous first attempt at mapping out Dutch ways of working through the atrocities perpetuated by Dutch soldiers. ${ }^{3}$ Bart Luttikhuis and Dirk Moses introduced a theme issue

1 Van den Doel, $A$ sscheid.

2 Schulte Nordholt, "A Genealology."

3 Scagliola, Last van de oorlog. 
of the Journal of Genocide Research in 2012 that focused on Dutch extreme violence during the decolonization war. ${ }^{4}$ It included contributions from scholars such as Scagliola, Bijl, Raben and Piet Romeijn.

However, a quarter of century after 1995, the memory of the war remains contested. Indonesian activist Jeffry Pondaag, journalist and historian Anne-Lot Hoek, lawyer Liesbeth Zegveld, Swiss-Dutch historian Remy Limpach and Indo prize-winning novelist Alfred Birney have each played important roles in provoking further debate in recent years. ${ }^{5}$ Limpach's study of Dutch military violence became front-page news. ${ }^{6}$ However, his research took place outside the guild, at the University of Berne, Switzerland. Activist historians, many working outside academia, pushed the history of unpleasant aspects of Dutch overseas history to the fore. Ewald Vanvugt published a long indictment of Dutch overseas crimes. Gloria Wekker accused Dutch academia of perpetuating white innocence and turning away from the sordid episodes of Dutch history. Anousha Nzume argued that the majority white population long for an unproblematic history that is "gezellig" ("cosy"), but when confronted with the fact of race they fall back on a defensive position of white fragility. ${ }^{7}$

In 2011, nearly 30 years after soldiers, in preparation for the radio series De kleine oorlog, had first publically admitted to carrying out a massacre, ${ }^{8}$ a court in The Hague found the Dutch state guilty of massacring 431 people in Rawagede, ordering compensation to be paid to ten widows of victims. In 2012, De Volkskrant published front-page photographs of Dutch soldiers shooting Indonesians at the edge of a mass grave. ${ }^{9}$ In 2013, the Dutch state was found guilty of war crimes in Sulawesi (South Celebes). ${ }^{10}$ In 2017, the Dutch state was accused of unlawfully killing six Moluccans and two

4 Luttikhuis and Moses, "Mass Violence."

5 Paul Doolan, "Response: Rewriting Dutch Colonial Histories," Imperial and Global Forum (blog), Centre for Imperial and Global History, University of Exeter, 12 December 2016, https:// imperialglobalexeter.com/2016/12/12/response-rewriting-dutch-colonial-histories/, accessed 12 July 2020.

6 Anne-Lot Hoek, “'Geweld Indië was structureel': 1945-1949 Nieuw historisch onderzoek maakt standpunt over 'excessen' Nederlandse militairen onhoudbaar," NRC Handelsblad, 14 August 2015 .

7 Vanvugt, Roofstaat; Wekker, White Innocence; Nzume, Hallo, 44-48, 109-111.

8 “Ex-trailleurs bekennen: 'Wij moorden kampong uit,'” Het Vrije Volk, 2o July 1983.

9 Lidy Nicolasen, "Eerste beeld van executies in Indonesië," De Volkskrant, 12 July 2012.

10 Paul Doolan, "Dutch Imperial Past Returns to Haunt the Netherlands," Imperial and Global Forum (blog), Centre for Imperial and Global History, University of Exeter, 6 April 2014, https:// imperialglobalexeter.com/2014/04/o6/dutch-imperial-past-returns-to-haunt-the-netherlands/, accessed 20 July 2020. 
hostages during the military assault that ended the train hijacking in $1977 .^{11}$ Such developments contributed to King Willem-Alexander apologizing in 2020 to Indonesia for the Dutch use of excessive violence. ${ }^{12}$

As Martijn Eickhoff argues, while atrocity photographs as well as the legal judgements in The Hague brought the war of decolonization to public attention, historians played a negligible role in all of this. During the Rawagede debate, it was "lawyers, politicians, activists, journalists, documentary makers, survivors and their relatives," who set the tone, and not historians. ${ }^{13}$ Nicole Immler and Stef Scagliola recently concluded that while the numbers of scholars who published on the issue was "limited," the court ruling of 2011 meant that the situation "changed entirely," with the ruling producing not only a new legal reality but also a new sense of "historical reality."14

A problem emerges when a legal court begins to write history and creates a dichotomy dividing the accuser and the accused, the victim and the perpetrator, the innocent and the guilty. Manichaeism makes for bad history. A promising way out of this simplification is to follow the suggestion of Raben, to engage in "a transcolonial" approach that would emphasize the entanglement of the various historical forces and actors and avoid the "binary opposition between the dominator and the dominated." Similarly, Susan Legêne, when considering the "colonial aphasia" of the Netherlands, argues that "we need to critically reflect on how historians have contributed to this." She goes on to call for an approach to the history of imperialism "that does not necessarily take the nation, or even Europe, as its frame of reference. ${ }^{16}$ The call for an entangled history that is transcolonial and transnational seems promising. Indeed, in November 2020 an example of such an entangled history was published. Rescaling the narrative by using oral histories as well as traditional research, Revolusi: Indonesië en het onstaan van de modern wereld (Revolusi: Indonesia and the creation of the modern world) is a work that combines multiple perspectives and embeds the Indonesian War of Independence in a global context. It is written for

11 Paul Doolan, "A Moluccan Victory in a Dutch Court," Imperial and Global Forum (blog), Centre for Imperial and Global History, University of Exeter, 13 March 2017, https://imperialglobalexeter. com/2017/03/13/a-moluccan-victory-in-a-dutch-court/, accessed 20 July 2020.

12 "Statement by King Willem-Alexander at the Beginning of State Visit to Indonesia," 10 March 2020, https://www.royal-house.nl/documents/speeches/2020/03/10/statement-byking-willem-alexander-at-the-beginning-of-the-state-visit-to-indonesia, accessed 20 July 2020.

13 Eickhoff, "Weggestreept," 57.

14 Immler and Scagliola, "Seeking Justice," 2.

15 Raben, Wie spreekt, 17.

16 Legêne, “The European," 112, 119. 
a wide audience, has quickly become a best seller and will undoubtedly contribute to shaping collective memory. However, this work did not emerge from inside the guild. The author is an independent scholar and a Belgian. ${ }^{17}$

In 2012, Piet Kampenhuis, director of the National Institute of Military History, declared that the debate around decolonization had become too emotional, describing discussions of massacres as a "commotion" and the publication of the photos in De Volkskrant as "hype. ${ }^{18}$ He warned that bringing the state to court could happen again "if we don't get the facts organized."19 This suggests that the contamination needed to be quarantined. In 2014, the government granted state funding to research the war. A team of historians, including Kampenhuis, is presently examining the period in order to produce a "definitive" publication. Gert Oostindie is scheduled to complete a synthesis of the research in 2022, providing the public with a readable history of decolonization. Asked on television why it took nearly 70 years to start this research, Oostindie commented: "historians have great trouble with the role of the activist judge. [...] [T] hat is, in fact, not so crazy or wrong." He explained: "It needed time to pass; it needed [...] the disappearance of a generation of military personnel and politicians. ${ }^{20} \mathrm{He}$ and two other historians argue that repatriates, military veterans, Dutch politicians and Indonesian authorities had obstructed investigation of the war. ${ }^{21}$ In other words, they list a variety of constituents, but they omit to mention the members of their own profession. Historians are absolved of responsibility in a contemporary example of unremembering. The conclusion of the present study disagrees.

\section{Bibliography}

Birney, Alfred. De Tolkvan Java. Breda: De Geus, 2018.

Doel, Henk W. van den. Afscheid van Indië: de valvan het Nederlandse imperium in Azië. Amsterdam: Prometheus, 2000.

17 Van Reybrouck, Revolusi.

18 Jan Schoeman, “'Oordeel op basis van kennis in plaats van emotie': Pleidooi integraal onderzoek Indië 1945-1949," Checkpoint: Maandblad voorveteranen 8 (October 2012): 10.

19 Ibid., 11.

20 Een mooi woord voor oorlog, NOS, 2 September 2017. The programme can be watched online: https://www.npostart.nl/een-mooi-woord-voor-oorlog/02-09-2017/POW_03603934, accessed 27 February 2021.

21 Oostindie, Hoogenboom and Verwey, “The Decolonization War," 259. 
Eickhoff, Martijn. "Weggestreept verleden? Nederlandse historici en het Rawagede debat." Groniek Historisch Tijdschrift 194 (2012): 53-67.

Immler, Nicole L. and Stef Scagliola. "Seeking Justice for the Mass Execution in Rawagede/Probing the Concept of 'Entangled History' in a Postcolonial Setting." Rethinking History 21, no. 1 (2020): 1-28.

Legêne, Susan. "The European Character of the Intellectual History of Dutch Empire." BMGN - Low Countries Historical Review 132, no. 2 (2017): 110-120.

Limpach, Remy. De brandende kampongs van generaal Spoor. Amsterdam: Boom, 2016.

Luttikhuis, Bart and Anthony Dirk Moses. "Mass Violence and the End of the Dutch Colonial Empire in Indonesia." Journal of Genocide Research 14, nos. 3-4 (2012): 257-276.

Nzume, Anousha. Hallo witte mensen. Amsterdam: Amsterdam University Press, 2017.

Oostindie, Gert, Irene Hoogenboom and Jonathan Verwey. "The Decolonization War in Indonesia, 1945-1949: War Crimes in Dutch Veteran's Egodocuments.” War in History 25, no. 2 (2018): 254-276.

Raben, Remco. Wie speekt voor het koloniale verleden? Een pleidooi voor transkolonialisme. Arnhem: Indisch Herinneringscentrum, 2016.

Reybrouck, David van. Revolusi: Indonesië en het onstaan van de modern wereld. Amsterdam: De Bezige Bij, 2020.

Scagliola, Stef. Last van de oorlog: de Nederlands oorlogsmisdaden in Indonesië en hun verwerking. Amsterdam: Balans, 2002.

Schulte Nordholt, Henk. "A Genealology of Violence in Indonesia." In Roots of Violence in Indonesia: Contemporary Violence in Historical Perspective, edited by Freek Colombijn and Thomas Lindblad. 33-61. Leiden: KITLV Press, 2002.

Vanvugt, Ewald. Roofstaat: Wat iedere Nederlander moet weten. Amsterdam: Nijgh en Van Ditmar, 2015.

Wekker, Gloria. White Innocence: Paradoxes of Colonialism and Race. Durham, NC, and London: Duke University Press, 2016.

\section{Television}

Een mooi woord voor oorlog. NOS, 2017. 


\section{Bibliography}

\section{Primary Sources}

\section{Newspapers}

Algemeen Dagblad

Algemeen Handelsblad

Algemeen Indisch Dagblad

Dagblad van het Noorden

De Gelderlander

De Haagsche Courant

De Java-Bode

De Nieuwsgier

De Telegraaf

De Tijd

De Tijd/De Maasbode

De Vlam

De Vrije Pers

De Volkskrant

De Waarheid

Friese Koerier

Gereformeerd Gezinsblad

Haarlems Dagblad

Heerenveense Koerier

Het Dagblad

Het Parool

Het Vaderland

Het Vrije Volk

Leeuwarder Courant

Limburgsch Dagblad

Nieuwe Rotterdamsche Courant

Nieuwsblad van Friesland

Nieuwsblad van het Noorden

Nieuwsblad van Sumatra

Limburgsch Dagblad

NRC Handelsblad

Proviciale Zeeuwse Courant

Reformatisch Dagblad 
Trouw

Utrechts Nieuwsblad

\section{Periodicals}

Elsevier

De Gids

De Groene Amsterdammer

HNMagazine

HP/De Tijd

Intermediair

Nieuw Israelietisch Weekblad

Politiek en Cultuur

Propria Cures

Vrij Nederland

\section{Cinema Newsreels}

Brengers van Recht en Veiligheid. Multifilm Batavia. [1947]. Disc 2. Nederlands Indië: Van tropische idylle tot harde realiteit. Hilversum: Netherlands Institute for Sound and Vision, 2011. DVD.

Een Grote Soldaat ging Heen. Multifilm Batavia. [1949]. Disc 2. Nederlands Indië: Van tropische idylle tot harde realiteit. Hilversum: Netherlands Institute for Sound and Vision, 2011. DVD.

Linggadjati in de branding. Multifilm Batavia. [1947]. Disc 3. Einde van Indië; Oorlog in Indonesië. Hilversum: Institute of Sound and Vision/Tijdsbeeld Media, 2011. DVD.

Soldaat Overzee. Multifilm Batavia. [1948]. Disc 2. Nederlands Indië: Van tropische idylle tot harde realiteit. Hilversum: Netherlands Institute for Sound and Vision, 2011. DVD.

Soldaat Overzee. Multifilm Batavia. [1948]. Disc 3. Einde van Indië: Oorlog in Indonesië. Hilversum: Institute of Sound and Vision/Tijdsbeeld Media, 2011. DVD.

Het Vreemde Leger: 2e politionele actie - Java en Sumatra. Multifilm Batavia. [1949].

Disc 2. Nederlands Indië: Van tropische idylle tot harde realiteit. Hilversum: Netherlands Institute for Sound and Vision, 2011. DVD.

\section{Radio}

Daarwerd iets grootsch verricht: of hoe het Koninkrijk der Nederlanden zijn grootste kolonie verloor. IKON, 1979.

De kleine oorlog. KRO, 1983.

Het Spoor Terug: Afscheid van Indië. VPRO, 1988. 


\section{Television}

Achter het Nieuws. VARA, 1969. [A series of three broadcasts.]

Altijd Wat. NCRV, 2012.

Ander Tijden: Onverwerkte oorlog in Indonesië, VPRO, 2015.

Antenne: Korban. EO, 1998.

De Bezetting. [1960-1965]. Directed and presented by Loe de Jong. Amsterdam: NIOD Institute for War, Holocaust and Genocide Studies/NTR, 2014. [Complete original edition of 21 episodes in boxed edition of seven DVDs.]

Dutch Approach: Gebroken belofte. NPS, 2000.

De Excessen in Rawagedeh. RTL $5,1995$.

Indonesia Merdeka. VPRO, 1976.

De Kampong staat in brand. RVU, 1989.

Het Land van mijn Ouders. IKON, 1983.

Een mooi woord voor oorlog. NOS, 2017.

"Ons Indië” voor de Indonesiërs. NOS, 1984.

Oorlog en Verzet in Nederlands-Indië. RVU, 1989.

Tabee Toean: Op patrouille in “Nederlands-Indië."NCRV, 1996. [Released in cinemas in 1995.]

De Tijd Staat Even Stil: De politionele acties. NCRV, 1993.

De Tijd Staat Even Stil: Poncke Princen. NCRV, 1994.

De Tijd Staat Even Stil: De Zuidmolukse droom. NCRV, 1994.

VeertigJaar na dato: Nederlands-Indië. I. AVRO, 1985.

VeertigJaar na dato: Nederlands-Indië. I.I AVRO, 1985.

De Verandering. NOS, 2015.

Wij komen als vrienden. VPRO, 1984. [Released in cinemas in 1984.]

\section{Film}

Gordelvan Smaragd. [1997]. Directed by Orlow Seunke. Universal Pictures (Benelux), 2004. DVD.

Indonesia Calling. [1946]. Disc 3. Joris Ivens Wereldcineast. Directed by Joris Ivens. Nijmegen: European Foundation Joris Ivens/CAPI Films, 2008. DVD.

Max Havelaar. [1976]. Directed by Fons Rademakers. A-Film, 2008. DVD.

Oeroeg. [1993]. Directed by Hans Hylkema. Woerden: Paramount Home Entertainment, 2005. DVD.

\section{Exhibitions}

“Koloniale oorlog 1945-1949: Gewenst en ongewenst beeld." Museum of the Resistance, Amsterdam, 26 November 2015-3 April 2016. 


\section{Books}

Alberts, A. Een kolonie is ook maar een mens. Amsterdam: Van Oorschot, 1989.

Alberts, A. Namen Noemen: Zo maar wat ongewone en openhartige herinneringen aan het leven in het verloren paradijs, dat Nederlands-Indië heette 1939-1947. Amsterdam: H.J. Paris, 1962.

Alberts, A. Romans en verhalen. Amsterdam: G.A. van Oorschot, 2007 [1952].

Alberts, A. Twee jaargetijden minder. Amsterdam: G.A. van Oorschot, 1992.

Bank, Jan. Katholieken en de Indonesische Revolutie. Barn: Ambo, 1983.

Bank, Jan, ed. De Excessennota: Nota Betreffende het archiefonderzoek naar de gegevens omtrent excessen in Indonesië begaan door Nederlandse militairen in de periode 1945-1950. The Hague: Sdu, 1995 [1969].

Bank, Jan and P. Romein, eds. Het Koninkrijk der Nederlanden in de Tweede Wereldoorlog, vol. 14b, Reacties. The Hague: Sdu, 1991.

Baudet, Henri and Cees Fasseur. "Koloniale bedrijvigheid." In De economische geschiedenis van Nederland, edited by J.H. van Stuijvenberg, 309-350. Groningen: Wolters-Noordhoff, 1979 .

Baudet, Henri and Meindert Fennema. Het Nederlands belang bij Indië. Utrecht/ Antwerp: Het Spectrum, 1983.

Bijkerk, J. C. De Laatste Landvoogd: Van Mook en het einde van Nederlandse invloed in Indië. Alphen aan den Rijn: A.W. Sijthoff, 1982.

Bloem, Marion. Geen gewoon Indisch meisje. Amsterdam: De Arbeiderspers, 2012 [first published Haarlem: In de Knipscheer, 1983].

Boomsma, Graa. De laatse tyfoon. $3^{\text {rd }}$ ed. Amsterdam: Van Gennep, 2012 [1992].

Bosscher, Doeko and Berteke Waaldijk. Ambon - Eer en Schuld: Politiek en pressie rond de Republiek Zuid-Molukken. Weesp: Van Holkema en Warendorf, 1985.

Bouman, Herman. Enige beschouwingen over de ontwikkeling van het Indonesisch Nationalisme op Sumatra's Westkust. Groningen/Batavia: J.B. Wolters, 1949.

Breton de Nijs, E. Faded Portraits. Translated by Donald and Elsje Sturtevant. Amherst: University of Massachusetts Press, 1982 [1954].

Breton de Nijs, E. “Oproep." Tong Tong 3, no. 23 (196o): 7.

Breton de Nijs, E. Tempo Doeloe: Fotografische documenten uit het oude Indië 1870-1914. Amsterdam: Querido, 1961.

Buitenweg, Hein. Kind in Tempo Doeloe. Wassenaar: Servire, 1969.

Dermoût, Maria. The Ten Thousand Things. Translated by Hans Koning. New York: NYRB Classics, 2002 [1956].

Dermoût, Maria. Verzameld werk. Amsterdam: Querido, 2000.

Dis, Adriaan van. De Indië Boeken. Amsterdam: Augustus, 2012.

Dis, Adriaan van. Nathan Sid. Amsterdam: Augustus, 2010 [1983]. 
Doorn, Jacques A.A. van. De laatste eeuw van Indië: Ontwikkeling en ondergang van een koloniaal project. Zutphen: Walburg Pers, 1994.

Doorn, Jacques A.A. van and Wim J. Hendrix. Ontsporing van geweld: over het Nederlands/Indisch/Indonesisch conflict. $4^{\text {th }}$ ed. Zutphen: Walburg Pers, 2012 [ ${ }^{\text {st }}$ ed., Rotterdam: Universitaire Pers Rotterdam, 1970].

Drooglever, Pieter J. "Dekolonisatie in twintig delen: Een persoonlijke impressie." BMGN - Low Countries Historical Review 111, no. 3 (1996): 464-472.

Drooglever, Pieter J. Review of Diplomatie of strijd. Een analyse van het Nederlands beleid tegenover de Indonesische revolutie 1945-1947, by J.J.P. de Jong. BMGN - Low Countries Historical Review 105, no. 2 (1990): 308-310.

Esterik, Chris van and Kees van Twist. Daar werd iets grootsch verricht: of hoe het Koninkrijk der Nederlanden zijn grootste kolonie verloor. Weesp: Heureka, 1980.

Fabius, Jan. Zwart op Wit-Liquidatie van een Imperium: Een beeld van de na-oorlogse regeringsbeleid in Nederland, ontleend aan de Nieuwsbrief. Amsterdam: Buijten en Schipperheijn, 1954.

Gase, Ronald. Beel in Batavia: Van contact tot conflict - Verwikkelingen rond de Indonesische kwestie in 1948. Baarn: Anthos/In den Toren, 1986.

Gerbrandy, Pieter S. Indonesia. London and New York: Hutchinson, $195^{\circ}$.

Gerretson, Carel. Indië onder Dictatuur. Amsterdam/Brussels: Elsevier, 1946.

Graaf, Hermanus J. de. "The Indonesian Declaration of Independence: $17^{\text {th }}$ of August 1945." Bijdragen tot de Taal, Land en Volkenkunde 115, no. 4 (1959): 305-327.

Graaff, Anton P. de. Brieven uit het veld. Franeker: Van Wijnen, 1989.

Graaff, Anton P. de. De heren worden bedankt. Franeker: Van Wijnen, 1986.

Graaff, Anton P. de. De weg terug. Franeker: Van Wijnen, 1988.

Graaff, Anton P. de. Levenslang op patrouille. Franeker: Van Wijnen, 2000

Graaff, Anton P. de. Merdeka. Franeker: Van Wijnen, 1995.

Graaff, Anton P. de. Met de TNI op stap. Franeker: Van Wijnen, 1991.

Graaff, Anton P. de. Notities van een soldaat. Franeker: Van Wijnen, 1995.

Graaff, Anton P. de. Zeg, Hollands soldaat.... Franeker: Van Wijnen, 1995.

Graeff, M.J. de, ed. Nederlandsch Indie 1945: Indonesië 1949: Achter het Nieuws 1969: drie VARA producties. Hilversum: VARA, 1969.

Groen, Petra M.H. Marsroutes en Dwaalsporen: Het Nederlands militair-strategisch beleid in Indonesië 1945-1950. The Hague: Sdu, 1991.

Groen, Petra M.H. and D.W. Staat. Inzet in Nederlands-Indie 1945-1950. Amsterdam: Van Soeren and Co., 1992.

Haasse, Hella S. Oeroeg. Amsterdam: Querido, 2009 [1948].

Hofland, Henk J.A. Tegels lichten of Ware verhalen over de autoriteiten in het land van de verdrongen feiten. $5^{\text {th }}$ ed. Amsterdam: Bert Bakker, 1986 [1972]. 
Hoogte, Albert van der. Het Laatste Uur: een kroniek uit het na-oorlogse Indonesië. Amsterdam/Antwerp: Contact, 1953.

Huxley, Aldous. The Perennial Philosophy. London: Chatto and Windus, 1946.

IJzereef, Willem. "De Zuid-Celebes affaire en de Nederlandse Pers 1946-1982." Groniek 8o (1982): 49-54.

IJzereef, Willem. De Zuid-Celebes affaire: Kapitein Westerling en de standrechtelijke executies. Dieren: De Bataafse Leeuw, 1984.

Ivens, Joris. "Documentary: Subjectivity and Montage." In Joris Ivens and the Documentary Context, edited by Kees Bakker, 250-260. Amsterdam: Amsterdam University Press, 1999.

Ivens, Joris. "Repeated and Organised Scenes in Documentary Film." In Joris Ivens and the Documentary Context, edited by Kees Baker, 261-271. Amsterdam: Amsterdam University Press, 1999.

Jaquet, Louis G.M. Aflossing van de Wacht: Bestuurlijke en politieke ervaringen in de nadagen van Nederlandsch-Indië. Rotterdam: A.D. Donker, 1978.

Jong, Joop J.P. de. Diplomatie of strijd:Een analyse van het Nederlands beleid tegenover de Indonesische Revolutie. Amsterdam: Boom, 1988.

Jong, Loe de. Het Koninkrijk der Nederlanden in de Tweede Wereldoorlog. Vol. 11a. Leiden: Martinus Nijhoff, 1985.

Jong, Loe de. Het Koninkrijk der Nederlanden in de Tweede Wereldoorlog. Vol. $12 \mathrm{~b}$. Leiden: Martinus Nijhoff, 1988.

Jonkman, Jan A. Nederland en Indonesië, beide vrij: Gezien vanuit het Nederlands Parlement. Assen/Amsterdam: Van Gorcum, 1977.

Kaam, Ben van. Ambon door de eeuwen. Baarn: Anthos, 1977.

Kadt, Jacques de. De Indonesische tragedie: Het treurspel van gemiste kansen. Amsterdam: G.A. van Oorschot, 1949.

Kwantes, R.C., ed. De ontwikkeling van de nationalistische beweging in NederlandschIndie::Development of the Nationalist Movement in the Netherlands-Indies, 4 vols. Groningen: Wolters-Noordhoff, 1975-1982.

Kleffens, Eelco N. van. “The Democratic Future of the Netherlands Indies." Foreign Affairs 21, no. 1 (1942): 87-102.

Laurens, Ben. De Vreet Patrouille. Rotterdam: Ad Donker, 1987.

Laurens, Ben. Het Peleton. Rotterdam: Ad Donker, 1986.

Liempt, Ad van. Een mooi woord voor oorlog: Ruzie, roddel en achterdocht op weg naar de Indonesië-oorlog. The Hague: Sdu, 1994.

Liempt, Ad van. Nederland Valt Aan: Op weg naar oorlog in Indonesië 1947. Amsterdam: Balans, 2012.

Lijphart, Arend. The Trauma of Decolonization: The Dutch and West New Guinea. New Haven and London: Yale University Press, 1966. 
Maas, Peter F. Indië Verloren, Rampspoed Geboren. Amsterdam: De Bataafsche Leeuw, 1983.

Mahieu, Vincent. Verzameld werk. Amsterdam: Querido, 1992.

Manusama, Johan A. "Political Aspects of the Struggle for Independence." In The South Moluccas: Rebellious Province or Occupied State, by Jan C. Bouman et al., 49-63. Leyden: A.W. Sythoff, 1960.

Meijer, Remco. Oostindisch doof: Het Nederlandse debat over de decolonisatie van Indonesië. Amsterdam: Bert Bakker, 1995.

Melief, Willem B.A.M. Evaluatie van de dienstverlening van "Stichting Dienstverlening Veteranen.” Utrecht: Verwey-Jonker Instituut, 1995.

Meulen, Daniel van der. Ik stond erbij: het einde van ons koloniale rijk. Baarn: Bosch en Keuning, 1965.

Mook, Hubertus J. van. “Indonesia." International Affairs 25, no. 3 (1949): 274-285.

Mook, Hubertus J. van. "Indonesia and the Problem of Southeast Asia." Foreign Affairs 27 (July 1949): 561-575.

Mook, Hubertus J. van. Indonesië, Nederland en de Wereld. Amsterdam: De Bezige Bij, 1949 .

Moor, Jaap A. de. "Het Korps Speciale Troepen." In De Politionele Acties, edited by Ger Teitler and Petra M.H. Groen, 121-143. Amsterdam: De Bataafsche Leeuw, 1987.

Nieuwenhuys, Rob. Mirror of the Indies: A History of Dutch Colonial Literature. Translated by Frans van Rosevelt, Edited with an introduction by E.M. Beekman. Amherst: University of Massachusetts Press, 1982 [1972].

Nieuwenhuys, Rob. Oost-Indische spiegel. Wat Nederlandse schrijvers en dichters over Indonesië hebben geschreven vanaf de eerste jaren der Compagnie tot op heden. Amsterdam: Querido, 1972.

Nieuwenhuys, Rob. Tussen Twee Vaderlanden. Amsterdam: G.A. van Oorschot, 1959. Pluvier, Jan M. Overzicht van de ontwikkeling der nationalistische beweging in Indonesië in de jaren 1930-1942. The Hague/Bandung: W. van Hoeve, 1953.

Poeze, Harry A. Tan Malaka:Strijder voor Indonesië's vrijheid - levensloop van 1897 tot 1945. The Hague: H.L. Smits, 1976.

Poeze, Harry and Henk Schulte Nordholt, eds. De roep om merdeka: Indonesische vrijheidslievende teksten uit de twintigste eeuw. Amsterdam: Mets/Novib, 1995.

Prins, Jan. “Location, History, Forgotten Struggle." In The South Moluccas: Rebellious Province or Occupied State, edited by Jan C. Bouman, 9-47. Leyden: A.W. Sythoff, 1960.

Riemens, J.W.E., ed. Wat gebeurt in Indonesië? Amsterdam: Comite voor Vrede in Indonesië, 1949 .

Robinson, Tjalie. Een land met gesloten deuren. Haarlem: In de Knipsheer, 2011.

Robinson, Tjalie. "Heeft ook Indisch Nederland historie? En hoe kunnen we helpen haar op te tekenen?" Onze Brug (August 1957): 2. 
Robinson, Tjalie. Kind van Batavia. Amsterdam: Prometeus Books, 2011.

Robinson, Tjalie. Piekerans van een straatslijper, 2 vols. Bandung: Masa Baru, 1952-1954.

Robinson, Tjalie. Taaie en Neut. The Haag: Edauw and Johannissen, 1994.

Robinson, Tjalie. “Tienduizend Dingen van Maria Dermoût.” Tong Tong 3 (August 1958): 2-3.

Robinson, Tjalie. Tjalie Robinson to J.W. Meyer Ranneft, 18 July 1955. In Schrijven met je vuisten: Brieven van Tjalie Robinson, edited by Wim Willems, 77-80. Amsterdam: Prometheus, 2009.

Robinson, Tjalie. Tjalie Robinson to J.W. Meyer Ranneft, 21 July 1955. In Schrijven met je vuisten:Brieven van Tjalie Robinson, edited by Wim Willems, 81-84. Amsterdam: Prometheus, 2009.

Robinson, Tjalie. Tjalie Robisnon to Maria Dermoût, 16 November 1955. In Schrijven met je vuisten: Brieven van Tjalie Robinson, edited by Wim Willems, 108-113. Amsterdam: Prometheus, 2009.

Romein, Jan M. The Asian Century: A History of Modern Nationalism in Asia. Translated by R.T. Clark. London: George Allen and Unwin, 1962.

Romein, Jan M. "The Spirit of the Dutch People during the Occupation." Annals of the American Academy of Political and Social Science 245 (May 1946):169-180.

Sahetapy, Abe. Tawanan (gevangenschap). Amsterdam: Joop Ririmase, 1982.

Schermerhorn, Wim. Het dagboek van Schermerhorn, 2 vols, edited by Cornelis Smit. Utrecht: Nederlands Historisch Genootschap, 1970.

Schilt, Jan. Soldaatje spelen onder de smaragden gordel. Amsterdam: Van Gennep, 1969. Schmid, A.P., J.F.A. de Graaf, F. Bovenkerk, L.M.Bovenkerk-Teerink and L. Brunt. Zuidmolukse terrorisme, de media en de publieke opinie: Twee studies van her Centrum voor Onderzoek van Maatschappelijke Tegenstellingen. Amsterdam: Intermediair, 1982.

Scholte, Lin. Verzamelde romans en verhalen. The Hague: Stichting Tong Tong, 2007. Schouten, Ted. Dwaalsporen: Oorlogsmisdaden in Nederlands-Indië. Zutphen: Alpha/Walburg Pers, 1995.

Seriese, Edy. Finding History: The Inheritance of the IWI Collection: Research Report for PhotoCLEC - Photographs, Colonial Legacy and Museums in Contemporary European Culture, IP2 - Indies Images of the Colonial Everyday in a Multi-Ethnic Postcolonial Society. Amsterdam: Indisch Wetenschappelijke Instituut, 2011.

Smit, Cornelis. De Dekolonisatie van Indonesië. Groningen: H.D. Tjeenk Willink, 1976. Smit, Cornelis. De Indonesische Quaestie. Leiden: E.J. Brill, $195^{2}$.

Smit, Cornelis. De Liquidatie van een Imperium. Amsterdam: De Arbeiderspers, 1962. Smulders, Robbert M. Een stem uit her veld: Herinneringen van Ritmeester-Adjuant van Generaal S.H. Spoor. Amsterdam: De Bataafsche Leeuw, 1988. 
Sprang, Alfred van. Laatste actie: een cocktail van soldatenleven en politiek in Indonesië. The Hague: W. van Hoeve, 1949.

Stolk, Jill. Indië was alles. Alles. Bergen: Van Stockum Bonnville, 1996.

Stolk, Jill. Scherven van Smargald. The Hague: Moesson, 1983.

Sytzen, Job. Soldaat/Ravijn/Landgenoten. Leiden: Slijthoff, 1957.

Teitler, Ger and Petra M. H. Groen, eds. De Politionele Acties. Amsterdam: De Bataafsche Leeuw, 1987.

Thenu, Cornelius. Korban: het verhaal van een Molukse activist. Amsterdam: De Arbeiderspers, 1998.

Varenne, Jan. Eer de haan kraait... Een serdadoe soesoe tussen de peloppers op Java. Amsterdam: Paris, 1969.

Veer, Paul van 't. De Atjeh-oorlog. Amsterdam: De Arbeiders Pers, 1969.

Veer, Paul van 't. Soekarno. The Hague: Kruseman, 1964.

Venner, Dominique. Westerling: De eenling. Amsterdam: Teleboek, 1982.

Visman, Frans H. "Provisional Government in the Netherlands East Indies." Pacific Affairs 18 (June 1945): 180-187.

Vuyk, Beb. Verzameld werk. Amsterdam: Querido, 1981.

Wal, Simon L. van der, Pieter J. Drooglever and Mieke J.B. Schouten. Officiële Bescheiden betreffende de Nederlands-Indonesische Betrekkingen 1945-1950, 20 vols. The Hague: Instituut voor Nederlandse Geschiedenis, 1971-1996.

Wertheim, Wim F. "Early Asian Trade: An Appreciation of J.C. van Leur." Far Eastern Quarterly 13, no. 2 (1952): 167-173.

Wertheim, Wim F. Preface to Overzicht van de ontwikkeling der nationalistische beweging in Indonesie in de jaren 1930-1942, by J. M. Pluvier, v-viii. The Hague/ Bandung: W. van Hoeve, 1953.

Wesseling, Henk L. Indiëverloren, rampspoed geboren en andere opstellen over de geschiedenis van de Europese expansie. Amsterdam: Bert Bakker, 1988.

Westerling, Raymond Paul Pierre. Mijn Memoires. Antwerp/Amsterdam: P. Vink, 1952. Zwaan, Jacob. Soldaat in Indië: de geschiedenis van een peloton. Zwolle:J.J. Tijl, 1969. Zwaan, Jacob and P.M.H. Groen. Oorlog en verzet in Nederlands-Indië 1941-1949 en de voorlichting aan de na-oorlogse generaties. Amsterdam: De Bataafsche Leeuw, 1989 .

\section{Secondary Sources}

Akihary, Huib. "Van Almere tot de Zwaluwenburg. Molukse woonoorden in Nederland.” In Tijdelijk Verblijf: De opvang van Molukkers in Nederland, 1951, edited by Wim Manuhutu and Henk Smeets, 40-73. Amsterdam: De Bataafsche Leeuw, 1991. 
Alatas, Syed Hussein. The Myth of the Native: A Study of the Image of the Malays, Filipinos and Javanese from the $16^{\text {th }}$ to the $20^{\text {th }}$ Century and Its Function in the Ideology of Colonial Capitalism. London: Frank Cass, 1977.

Anderson, Benedict. Imagined Communities: Reflections on the Origin and Spread of Nationalism. Rev. extended ed. London and New York: Verso, 1991.

Ankersmit, Frank. Meaning, Truth and Reference in Historical Representation. Ithaca, NY: Cornell University Press, 2012.

Assmann, Aleida. Cultural Memory and Western Civilization: Functions, Media, Archives. New York: Cambridge University Press, 2011.

Assmann, Aleida. Is die Zeit aus den Fugen? Aufsteig und Fall des Zeitregimes der Moderne. Munich: Carl Hanser Verlag, 2013.

Assmann, Aleida. Formen des Vergessens. Göttingen: Wallstein Verlag, 2017.

Assmann, Aleida. "To Remember or to Forget: Which Way Out of a Shared History of Violence?" In Memory and Political Change, edited by Aleida Assmann and Linda Shortt, 53-71. Basingstoke: Palgrave Macmillan, 2012.

Assmann, Aleida and Linda Shortt. "Memory and Political Change: Introduction." In Memory and Political Change, edited by Aleida Assmann and Linda Shortt, 1-14. Basingstoke: Palgrave Macmillan, 2012.

Assmann, Aleida and Linda Shortt, eds., Memory and Political Change. Basingstoke: Palgrave Macmillan, 2012.

Assmann, Jan. "Communicative and Cultural Memory." In Cultural Memory Studies: An International and Interdisciplinary Handbook, edited by Astid Erll and Ansgar Nünning, 109-118. Berlin: Walter de Gruyter, 2008.

Auge, Marc. Non-Places: An Introduction to Supermodernity. London and New York: Verso, 2008.

Baay, Reggie. De njai: Het concubinaat in Nederlands-Indië. Amsterdam: AthenaeumPolak \& Van Gennep, 2008.

Baay, Reggie and Peter van Zonneveld, eds., Indisch-Nederlandse literatuur: dertien bijdragen voor Rob Nieuwenhuys. Utrecht, HES, 1988.

Bakker, Kees, ed.Joris Ivens and the Documentary Context. Amsterdam: Amsterdam University Press, 1999.

Bank, Jan. "Televisie in de jaren zestig." Bijdragen en Mededelingen betreffend de Geschiedenis der Nederlanden 101, no. 1 (1986): 52-75.

Bartels, Dieter. "Can the Train Ever Be Stopped Again? Developments in the Moluccan Community in the Netherlands Before and After the Hijackings." Indonesia 41 (April 1986): 23-45.

Barthes, Roland. Camera Lucida: Reflections on Photography. Translated by Richard Howard. London: Vintage Books, 1993 [1980].

Batchen, Geoffrey. Forget Me Not: Photography and Remembrance. New York and Amsterdam: Princeton Architectural Press/Van Gogh Museum, 2004. 
Baudrillard, Jean. Simulacra and Simulation. Translated by Sheila Faria Glaser. Ann Arbor: University of Michigan Press, 1994 [1981].

Beekman, Eric M. Introduction to Mirror of the Indies: A History of Dutch Colonial Literature by Rob Nieuwenhuys, xii-xxiii. Translated by Frans van Rosevelt. Edited by E.M. Beekman. Amherst: University of Massachusetts Press, 1982 [1972].

Beekman, Eric M. Troubled Pleasures: Dutch Colonial Literature from the East Indies 1600-1950. Oxford: Clarendon Press, 1996.

Beus, Jos de. "God dekoloniseert niet: Een kritiek op de Nederlandse geschiedschrijving over de neergang van Nederlands-Indië en Nederlands Suriname." BMGN - Low Countries Historical Review 116, no. 3 (2001): 307-324.

Bhabha, Homi K. The Location of Culture. London and New York: Routledge, 1994. Bijl, Paul. Emerging Memory: Photographs of Colonial Atrocity in Dutch Colonial Remembrance. Amsterdam: Amsterdam University Press, 2015.

Birney, Alfred. De Tolkvan Java. Breda: De Geus, 2018.

Bissell, William Cunningham. "Engaging Colonial Nostalgia." Cultural Anthropology 20, no. 2 (2005): 215-248.

Blaut, James M. The Colonizer's Model of the World: Geographical Diffusionism and Eurocentric History. New York and London: Guildford Press, 1993.

Bloch, Marc. The Historian's Craft. Translated by Peter Putnam. New York: Vintage Books, 1953 .

Bloembergen, Marieke. Colonial Spectacles: The Netherlands and the Dutch East Indies at the World Exhibitions. Translated by Beverley Jackson. Singapore: Singapore University Press, 2006.

Bloembergen, Marieke. “Oeroeg.” In Een Open Zenuw: Hoe wij ons de tweede wereldoorlog herinneren, edited by Madelon de Keizer and Marije Plomp, 421-431. Amsterdam: Bert Bakker, 2010.

Boehmer, Elleke and Sarah de Mul, eds., The Postcolonial Low Countries: Literature, Colonialism, Multiculturalism. Plymouth: Lexington Books, 2012.

Bogaerts, Els. “Tussen tekst en herinnering: Maria Dermoûts Java's." Indische Lettern 15 , no. 2 (2000): 50-67.

Bogaerts, Els and Remco Raben. "Beyond Empire and Nation." In Beyond Empire and Nation: Decolonizing Societies in Africa and Asia, 1930s-1970s, edited by Els Bogaerts and Remco Raben, 7-21. Leiden: KITLV Press, 2012.

Bogaerts, Els and Remco Raben, eds. Beyond Empire and Nation: Decolonizing Societies in Africa and Asia, 1930s-1970s. Leiden: KITLV Press, 2012.

Boomsma, Graa. Leven op de rand: Biografie van A. Alberts. Amsterdam: Van Oorschot, 2017.

Bootsma, Peter. De Molukse Acties: Treinkapingen en gijzelingen 1970-1978. Amsterdam: Boom, 2015. 
Born, Karin van den, Gerda Jansen Hendriks, Yfke Nijland and Ad van Liempt. "De Excessennota." In Andere Tijden: Nieuwe inzichten in oude kwesties, edited by Ad van Liempt, 162-176. Amsterdam/Antwerpen: L.J. Veen, 2002.

Bosma, Ulbe. Terug uit de Koloniën: Zestig jaar postkoloniale migranten en hun organisaties. Amsterdam: Bert Bakker, 2009.

Bosma, Ulbe, ed. Post-Colonial Immigrants and Identity Formations in the Netherlands. Amsterdam: Amsterdam University Press, 2012.

Bosma, Ulba, Remco Raben and Wim Willems. De Geschiedenis van Indische Nederlanders. Amsterdam: Bert Bakker, 2006.

Bourdieu, Pierre and Jean-Claude Passeron. Reproduction in Education, Society and Culture. Translated by Richard Nice. London: Sage Publications, 1990.

Bourke, Johanna. “Introduction: 'Remembering' War.” Journal of Contemporary History 39, no. 4 (2004): 473-485.

Brante, Thomas. "Sociological Approaches to the Professions." Acta Sociologica 31, no. 2 (1988): 119-142.

Brocades Zaalberg, Thijs and Wim Willems. "Onmacht. Ontkenning en Onderschatting: De evacuaties van Nederlanders uit Zuidoost-Azie na de Tweede Wereldoorlog." In Binnenkamers: Terugkeer en opvang na de Tweede Wereldoorlog - Besluitvorming, edited by Conny Kristel, 63-92. Amsterdam: Bert Bakker, 2002.

Bussemaker, Herman. Indisch verdriet: Strijd om erkenning. Amsterdam: Boom, 2014. Chakrabarty, Dipesh. "History and the Politics of Recognition." Manifestos for History, edited by Keith Jenkins, Sue Morgan and Alun Munslow, 77-87. London and New York: Routledge, 2007.

Chirot, Daniel, Gi-Wook Shin and Daniel Sneider, eds. Confronting Memories of World War II. Seattle and London: University of Washington Press, 2014.

Clerkx, Lily E. and Wim F. Wertheim. Living in Deli: Its Society as Imaged in Colonial Fiction. Amsterdam: VU University Press, 1991.

Connerton, Paul. How Societies Remember. Cambridge: Cambridge University Press, 1996.

Connerton, Paul. How Modernity Forgets. Cambridge: Cambridge University Press, 2009.

Connerton, Paul. The Spirit of Mourning: History, Memory and the Body. New York: Cambridge University Press, 2011.

Cooper, Frederick. Colonialism in Question: Theory, Knowledge, History. Berkeley, Los Angeles and London: University of California Press, 2005.

Cote, Joost. "Strangers in the House: Dutch Historiography and Anglophone Trespassers." Review of Indonesian and Malaysian Affairs 3, no. 1 (2009): 75-94.

Cottaar, Annemarie and Wim Willems, Indische Nederlanders: Een onderzoeknaar beeldvorming. The Hague: Moesson, 1984. 
Cottle, Drew and Angela Keys. "From Colonial Film Commissioner to Political Pariah: Joris Ivens and the Making of Indonesia Calling." Senses of Cinema 41 (2006). http://www.sensesofcinema.com/2006/41/ivens-indonesia-calling. Accessed 15 April 2015.

Creet, Julia and Andreas Kitzmann, eds. Memory and Migration: Multidisciplinary Approaches to Memory Studies. Toronto: Toronto University Press, 2011.

Cribb, Robert. "Circles of Esteem, Standard Works, and Euphoric Couplets." Critical Asian Studies 37, no. 2 (2005): 289-304.

Daelen, Verle Vanden. "Loe De Jong en Maurice De Wilde: Twee oorlogsmonumenten." Bijdragen tot de Eigentijdse Geschiedenis 22 (2010): 161-196.

Delmar, Rosalind. Joris Ivens: 50 Years of Filmmaking. London: British Film Institute, 1979.

Derrida, Jacques. “The Parergon.” Translated by Craig Owens. October 9 (Summer 1979): 26 .

Derrida, Jacques. “Time Is Out of Joint.” In Deconstruction Is/In America, edited by Anselm Haverkamp, 14-38. New York: New York University Press, 1995.

Derrida, Jacques. "Deconstruction and the Other." In: States of Mind: Dialogues with Contemporary Thinkers, edited by Richard Kearney, 156-176. New York: New York University Press, 1995.

Dewulf, Jeroen, Praamstra, Olf and Michiel van Kempen, eds. Shifting the Compass: Pluricontinental Connections in Dutch Colonial and Postcolonial Literature. Newcastle: Cambridge Scholars Publishing, 2013.

Dis, Adriaan van. Ik Kom Terug. Amsterdam: Augustus, 2014.

Dis, Adriaan van. "Klagen met een mopje." De Gids 1 (2011): 24-31.

Dis, Adriaan van. "Squeezed between Rice and Potato: Personal Reflections on a Dutch (Post) Colonial Youth." In Shifting the Compass: Pluricontinental Connections in Dutch Colonial and Postcolonial Literature, edited by Jeroen Dewulf, Olf Praamstra and Michiel van Kempen, 20-37. Newcastle: Cambridge Scholars Publishing, 2013.

Doel, Henk W. van den. Afscheid van Indië: de valvan het Nederlandse imperium in Azië. Amsterdam: Prometheus, 2000.

Dolle, Esther ten. "Een moord in Indonesië: feit en fictie achter de geweldexcessen. Hollands Maanblad 45, no. 4 (2004): 3-11.

Dolle, Esther ten. "Morality Is Another Story." Dutch Crossing 27, no. 2 (2003):169-180. Doolan, Paul. “Marie Dermoût and 'Unremembering' Lost Time.” Canadian Journal of Netherlandic Studies 34, no. 2 (2013): 1-28.

Doolan, Paul. "Reservoirs of Violence: Beb Vuyk's postcolonial stories." Canadian Journal of Netherlandic Studies 40, no. 2 (2020): 39-70.

Doorn, Jacques A.A. van. Gevangen in de tijd. Over generaties en hun geschiedenis. Amsterdam: Boom, 2002. 
Eickhoff, Martijn. “Weggestreept verleden? Nederlandse historici en het Rawagede debat." Groniek Historisch Tijdschrift 194 (2012): 53-67.

Erll, Astrid. Memory in Culture. Basingstoke: Palgrave Macmillan, 2011.

Erll, Astrid and Ansgar Nünning, eds. Cultural Memory Studies: An International and Interdisciplinary Handbook. Berlin: Walter de Gruyter, 2008.

Fanon, Frantz. Black Skin, White Masks. Translated by Charles Lam Markmann. London: Pluto Press, 1986 [1952].

Fanon, Frantz. The Wretched of the Earth. Translated by Richard Philcox. New York: Grove Press, 2004 [1961].

Fasseur, Cees. Dubbelspoor: Herinneringen. Amsterdam: Balans, 2016.

Fasseur, Cees. Eigen meester, niemands knecht: Het leven van Pieter Sjoerds Gerbrandy, Minister-presidentvan Nederland in de Tweede Wereldoorlog. Amsterdam: Balans, 2014.

Fish, Stanley. “One More Time.” In Postmodern Sophistry: Stanley Fish and the Critical Enterprise, edited by Gary A. Olson and Lynn Worsham, 265-298. Albany: State University of New York Press, 2004.

Foray, Jennifer L. "Comparatively Exceptional: The Paradoxes of Twentieth-Century Dutch Imperialism and Decolonization.” The Dutch Empire between Ideas and Practise, 1600-200o, edited by René Koekkoek, Anne-Isabella Richard and Arthur Weststeijn, 89-108. London: Palgrave Macmillan, 2019.

Foray, Jennifer L. "The Trauma of Liberation: Dutch Political Culture and the Indonesian Question in 1945." Historical Reflections 41, no. 3 (2015): 79-94.

Freriks, Kester. Echo's van Indie: De onafhankelijkheid van Indonesië in verhalen en herinneringen. Amsterdam: Athenaeum-Polak \& Van Gennep, 2015.

Freriks, Kester. Geheim Indië: Het leven van Maria Dermoût 1888-1962. Amsterdam: Querido, 2000.

Galen, John Jansen van. Afscheid van de Koloniën: Het Nederlandse Dekolonisatiebeleid 1942-2012. Amsterdam and Antwerp: Atlas Contact, 2013.

Gemert, Stefanie van. “'A Sort of Wishful Dream': Challenging Colonial Time and 'Indische' Identities in Hella S. Haasse's Oeroeg, Sleuteloog in Contemporary Reviews." In Discord and Consensus in the Low Countries, edited Jane Fenoulhet, Gerdi Quist and Ulrich Tiedau, 118-132. London: UCL Press, 2016.

Gennep, Arnold van. The Rites of Passage, trans. Monika B. Vizedom and Gabrielle L. Caffee. London: Routledge, 1960 [1908].

Ginkel, Rob van. "4 en 5 mei." In Een open zenuw: Hoe wij ons de tweede wereldoorlog herinneren, edited by Madelon de Keizer and Marije Plomp, 27-38. Amsterdam: Bert Bakker, 2010.

Goos, Marije. Een hard en waakzaam hond:Engagement in de literaire tijdschrijften van "de lange jaren vijftig"1950-1963. Hilversum: Verloren, 2016. 
Goss, Andrew. "From Tong-Tong to Tempo Doeloe: Eurasian Memory Work and the Bracketing of Dutch Colonial History, 1957-1961." Indonesia 70 (October 2000): 9-36.

Gouda, Frances. "Divided Memories of World War II in the Netherlands and the Dutch East Indies: Sukarno and Anne Frank as Icons of Dutch Historical Imagination." In Confronting Memories of World War II: European and Asian Legacies, edited by Daniel Chirot, Gi-Wook Shin and Daniel Sneider, 105-134. Seattle and London: University of Washington Press, 2014.

Gouda, Frances. Dutch Culture Overseas: Colonial Practice in the Netherlands Indies 1900-1942. Amsterdam: Amsterdam University Press, 1995.

Groen, Petra M.H. “Geweld en geweten: Koloniale oorlogvoering en militaire ethiek in Nederlands-Indië, 1816-1941." Militaire Spectator 182, no. 5 (2013): 248-266.

Hagebeuk, Lieke. "Indië verloren, rampspoed geboren? Een analyse van politieke besluitvorming en berichtgeving over de dekolonisatie van Indonesië." MA thesis, University of Groningen, 2009. http://arts.studenttheses.ub.rug.nl/9242/1/ MA-s1587013-L.Hagebeuk.pdf. Accessed 15 April 2015.

Halbwachs, Maurice. On Collective Memory. Edited and translated by Lewis A. Coser. Chicago and London: University of Chicago Press, 1992 [1950].

Hanan, David. "Fellow Travellers.” Meanjin 66, no. 2 (2007): 52-58.

Havenaar, Ronald. De tocht naar het onbekende: Het politieke denken van Jacques de Kadt. Amsterdam: G.A. van Oorschot, 1990.

Heffernan, Margaret. Wilful Blindness: Why We Ignore the Obvious at Our Peril. London: Simon and Schuster, 2012.

Hirsch, Marianne. Family Frames: Photography, Narrative and Postmemory. Cambridge, MA, and London: Harvard University Press, 1997.

Hirsch, Marianne. The Generation of Postmemory: Writing and Visual Culture after the Holocaust. New York: Columbia University Press, 2012.

Hoffman, Eva. "The Long Afterlife of Loss." In Memory: Histories, Theories, Debates, edited by Susannah Radstone and Bill Schwartz, 406-415. New York: Fordham University Press, 2010.

Hogenkamp, Bert. "Indonesia Calling: A Film on the Crossroads of Four Continents." Labour History 73 (November 1997): 226-231.

Hogenkamp, Bert. "A Special Relationship: Joris Ivens and the Netherlands." Joris Ivens and the Documentary Context, edited by Kees Bakker, 183-194. Amsterdam: Amsterdam University Press, 1999.

Houben, Vincent J.H. "A Torn Soul: The Dutch Public Discussion on the Colonial Past in 1995." Indonesia 63 (April 1997): 47-66.

Houtzager, Guus. "Maria Dermoûts De tienduizend dingen: Technisch raffinement, tovenarij en taoïsme." Indische Letteren 1, no. 2 (1986): 67-87. 
Hugenholtz, Wouter R. "Nederlands-Indië en het Gouvernmentele Paradigma.” Groniek 17 (1982): 20-28.

Immler, Nicole L. and Stef Scagliola. "Seeking Justice for the Mass Execution in Rawagede/Probing the Concept of 'Entangled History' in a Postcolonial Setting." Rethinking History 21, no. 1 (2020): 1-28.

Jansen Hendriks, Gerda. "Bersiap: Joris Ivens and the Early Indonesian Revolution.” Joris Ivens Newsmagazine 9 (November 2003): 20-22.

Jansen Hendriks, Gerda. "Een voorbeeldige kolonie: Nederlands-Indië in 50 jaar overheidsfilms 1912-1962." PhD diss., University of Amsterdam, 2014.

Jansen Hendriks, Gerda, Frank Klein and Petter Otten. "The Final Years of the Dutch East Indies as Recorded by Multifilm Batavia." Historical Journal of Film, Radio and Television 5, no. 1 (1985): 77-83.

Jong, Joop J.P. de. Avondschot: Hoe Nederland zich terugtrok uit zijn aziatisch imperium. Amsterdam: Boom, 2011.

Junger, Sebastian. Tribe: On Homecoming and Belonging. New York and Boston: Twelve, 2016.

Keizer, Madelon de. 'Mission Impossible'. De bemiddelaarsrol van Frans Goedhart in het Nederlands-Indonesische conflict, 1945-1947." Bijdragen en Mededelingen betreffende de Geschiedenis der Nederlanden 100, no. 3 (1995): 352-379.

Keizer, Madelon de and Marije Plomp, eds., Een open zenuw: How wij ons de tweede wereldoorlog herinneren. Amsterdam: Bert Bakker, 2010.

Kok, Rene, Erik Somers and Louis Zweers. Koloniale Oorlog: Van Indië naar Indonesië. Amsterdam: Carrera, 2015.

Kousbroek, Rudy. Het Oostindisch Kampsyndroom. Amsterdam: Olympus, 2005.

Kristel, Conny. "Inleiding." In Binnenkamers: Terugkeer en opvang na de Tweede Wereldoorlog - Besluitvorming, edited by Conny Kristel, 7-21. Amsterdam: Bert Bakker, 2002.

Kristel, Conny, ed. Binnenkamers: Terugkeer en opvang na de Tweede Wereldoorlog - Besluitvorming. Amsterdam: Bert Bakker, 2002.

Kroef, Justus M. van der. “The Colonial Novel in Indonesia." Comparative Literature 10, no. 3 (Summer 1958): 215-231.

Kroef, Justus M. van der. "On the Writing of Indonesian History." Pacific Affairs 31, no. 4. (1958): 352-371.

Kuitenbrouwer, Maarten. Dutch Scholarship in the Age of Empire and Beyond: KITLV - The Royal Netherlands Institute of Southeast Asian and Caribbean Studies, 1851-2011. Leiden and Boston: Brill, 2014.

Leeuwen, Lizzie van. "Het Indisch Huis." In Een Open Zenuw: How wij ons de Tweede Wereldoorlog herinneren, edited by Madelon de Keizer and Marieke Plomp, 275-282. Amsterdam: Bert Bakker, 2010. 
Legêne, Susan. "The European Character of the Intellectual History of Dutch Empire." BMGN - Low Countries Historical Review 132, no. 2 (2017): 110-120.

Lijphart, Arend. "Political Institutions, Divided Societies, and Constitutional Democracy." In Passion, Craft, and Method in Comparative Politics, edited by Gerardo L. Munck and Richard Snyder, 237-244. Baltimore:Johns Hopkins University Press, 2007. Limpach, Remy. De brandende kampongs van generaal Spoor. Amsterdam: Boom, 2016. Lipkin, Steven N. Docudrama Performs the Past: Arenas of Argument in Films Based on True Stories. Newcastle upon Tyne: Cambridge Scholars Publishing, 2011.

Locher-Scholten, Elsbeth. "De ontwikkeling van de nationalistische beweging in Nederlands-Indië." Bijdragen en Mededelingen betreffende de Geschiedenis der Nederland 99, no. 1 (1984): 45-54.

Locher-Scholten, Elsbeth. "Een bronnenpublicatie als signaal van koloniale trauma? Ontstaan en ontvangst van de Officiële bescheiden." Bijdragen en Mededelingen betreffende de Geschiedenis der Nederlanden 111, no. 4 (1996): 473-492.

Luttikhuis, Bart and Anthony Dirk Moses. "Mass Violence and the End of the Dutch Colonial Empire in Indonesia." Journal of Genocide Research 14, nos. 3-4 (2012): 257-276.

Maar, Rimko van de. Welterusten meneer de president: Nederland en de Vietnam Oorlog, Amsterdam: Boom, 2007.

Maier, Henk M.J. "Escape from the Green and Gloss of Java: Hella S. Haasse and Indies Literature." Indonesia 77 (April 2004): 79-107.

Manuhutu, Wim. "Help Ambon in Nood. De rol van het particulier initiatief bij de RMS en de opvang van Molukkers in Nederland." In Tijdelijk Verblijf: De opvang van Molukkers in Nederland, 195, edited by Wim Manuhutu and Henk Smeets, 74-87. Amsterdam: De Bataafsche Leeuw, 1991.

Manuhutu, Wim and Henk Smeets, eds. Tijdelijk Verblijf: De opvang van Molukkers in Nederland, 1951. Amsterdam: De Bataafsche Leeuw, 1991.

McLuhan, Marshall. The Medium Is the Massage. London: Penguin, 2008 [1967].

McLuhan, Marshall. Understanding Media: The Extensions of Man. London and New York: Routledge, 1964.

Meijer, H. Review of Officiële Bescheiden betreffende de Nederlands-Indonesische Betrekkingen 1945-1950, vol. 20, by P.J. Drooglever and M.J.B. Schouten, BMGN - Low Countries Historical Review 113, no. 3 (1998): 454-455.

Mink, Louis O. “The Theory of Practise: Hexter's Historiography." In After the Reformation: Essays in Honor ofJ.H. Hexter, edited by Barbara C. Malament, 3-24. Manchester: Manchester University Press, 1980.

Mooij, Annet. “De Langste Schaduw: Het denken over psychische oorlogsgevolgen.” In Binnenskamers: Terugkeer en opvang na de Tweede Wereldoorlog-Besluitvorming, edited by Conny Kristel, 261-291. Amsterdam: Bert Bakker, 2002. 
Moor, Jaap A. de. Generaal Spoor: Triomf en tragiek van een legercommandant. Amsterdam: Boom, 2011.

Moor, Jaap A. de. "Van vrije jongen tot ratu adil: De memoires van kapitein Raymond Westerling." Indische Letteren 8, no. 1 (1993): 171-179.

Mrázek, Rudolf and Gertrudes Johan Resink. “Coughing Heavily: Two Interviews with Professor Resink in His Home at Gondangdia Lama 48A, Jakarta, on July 17 and July 25, 1997." Indonesia 74 (October 2002): 137-164.

Mul, Sarah de. Colonial Memory: Contemporary Women's Travel Writing in Britain and the Netherlands. Amsterdam: Amsterdam University Press, 2011.

Nas, Peter J.M. and Maaike Boersma. "Feeling at Home, Dealing with the Past: Indonesian and Colonial Architecture in the Netherlands." In The Past in the Present: Architecture in Indonesia, edited by Peter J.M. Nas, 147-162. Rotterdam: NAi Publishers, 2006.

Nora, Pierre. "Between Memory and History: Les Lieux de Mémoire." Representations 26 (Spring 1989): 7-28.

Nzume, Anousha. Hallo witte mensen. Amsterdam: Amsterdam University Press, 2017.

Olick, Jeffrey K. The Politics of Regret: On Collective Memory and Historical Responsibility. Oxon: Routledge, 2007.

Oostindie, Gert. Post Koloniaal Nederland: Vijfenzestig jaar vergeten, herdenken, verdringen. Amsterdam: Bert Bakker, 2010.

Oostindie, Gert. Soldaat in Indonesië 1945-1950: Getuigenissen van een oorlog aan de verkeerde kant van de geschiedenis. Amsterdam: Prometheus, 2015.

Oostindie, Gert, Henk Schulte Nordholt and Fridus Steijlen. Postkoloniale Monumenten in Nederland/Post-Colonial Monuments in the Netherlands. Leiden: KITLV Press, 2011.

Oostindie, Gert, Irene Hoogenboom and Jonathan Verwey. "The Decolonization War in Indonesia, 1945-1949: War Crimes in Dutch Veteran's Egodocuments." War in History 25, no. 2 (2018): 254-276.

Passman, Bert. "Van Tjalie zijn wij nog niet af." In Tjalie Robinson: de stem van Indisch Nederland, edited by Bart Passman, Wilma Scheffers, Edy Seiese, Peter Zonbeveld and Adrienne Zuiderweg. The Haag: Stichting Tong Tong, 1994.

Pattynama, Pamela. Bitterzoet Indië: Herinnering en nostalgie in literatuur, foto's en films. Amsterdam: Prometheus-Bert Bakker, 2014.

Pattynama, Pamela. "Cultural Memory and Indo-Dutch Identity Formations." In Post-Colonial Immigrants and Identity Formations in the Netherlands, edited by Ulbe Bosma, 175-192. Amsterdam: Amsterdam University Press, 2012.

Pattynama, Pamela. "Herinneringsliteratuur en 'postherinneringen' bij eerste en tweede generatie Indische schrijvers." In Kunsten in Beweging: Cultuur en migratie in Nederland, edited by Rosemarie Buikema and Maaike Meijer, 207-221. The Hague: Sdu, 2003. 
Pattynama, Pamela. “Laat mij voor één keer schaamteloos terug verlangen...': De herinneringsknoop van Indische nostalgie." Indische Letteren 23, no. 2 (2008): 50-62.

Pattynama, Pamela. "Postkoloniale Erinnerung an (Niederlandisch-) Indien: koloniale Vergangenheit, kulturelle Erinnerung und Literatur." In Kolonialismus und Erinnerungskultuur: Die Kolonialevergangenheit im kollectiven Gedächtnis der deutschen und niederländischen Einwanderungsgesellschaft, edited by Helma Lutz and Kathrin Gawarecki, 111-126. Munster: Waxman Verlag, 2005.

Pattynama, Pamela. "(Un)happy Endings: Nostalgia in Postcolonial and Postmemory Dutch Films." In The Postcolonial Low Countries: Literature, Colonialism, Multiculturalism, edited by Elleke Boehmer and Sarah de Mul, 97-122. Plymouth: Lexington Books, 2012.

Pieter, Nadap. "Geloof in Nederlands roeping: Koloniale journalistiek in Indonesië tijdens de Politionele Acties 1947-1949." MA thesis, University of Groningen, 2009. http://arts.studenttheses.ub.rug.nl/9593/1/MA-1408097-Pieter-N-scriptie. pdf. Accessed 16 April 2015.

Poeze, Harry A. Dominee Jac. Jonker, Job Sytzen en de Soldaat in Indië. Hilversum: Verloren, 2019.

Poeze, Harry A. Verguisd en Vergeten: Tan Malaka, de linkse beweging en de Indonesische Revolutie, 1945-1949, 3 vols. Leiden: KITLV Uigeverij, 2007.

Praamstra, Olf. "Afscheid en de grenzen van de tijd: animistische ideeën in De tienduizend dingen van Maria Dermoût." In Kerven in een rots: Opstellen over nederlandse taalkunde, letterkunde en cultuur, aangeboden aan Jan W. de Vries bij zijn afscheid als hoogleraar Dutch Studies aan de Universiteit Leiden, edited by Berry Dongelmans, Josien Lalleman and Olf Praamstra, 191-201. Leiden: Stichting Neerlandistiek, 2001.

Praamstra, Olf. “'Going Native': Beb Vuyk en het verlangen naar een Indonesische Identiteit." Spiegel der Letteren 58, no. 1 (2016): 43-81.

Praamstra, Olf. "A World of Her Own: The Eurasian Way of Living and the Balance between East and West in Maria Dermoût's The Ten Thousand Things." In Shifting the Compass: Pluricontinental Connections in Dutch Colonial and Postcolonial Literature, edited by Jeroen Dewulf, Olf Praamstra and Michiel van Kempen, 56-68. Newcastle: Cambridge Scholars Publishing, 2013.

Prins, Baukje. Gemengde Gevoelens: Molukse en Nederlandse klasgenoten in de jaren zestig. Amsterdam: Van Gennep, 2014.

Protschky, Susie. “Tea Cups, Cameras and Family Life: Picturing Domesticity in Elite European and Javanese Family Photographs from the Netherlands Indies 1900-1942." History of Photography 36, no. 1 (2012): 44-65.

Protschky, Susie. "Burden of Proof: Photography and Evidence of Atrocity during the Dutch Military Actions in Indonesia 1945-1950." Bijdragen tot de Taal-, Land-en Volkenkunde 176 (2020): 240-278. 
Raben, Remco. “De dagen van de grote uittocht?" Indische Letteren 32, no. 1 (2017): 20-32.

Raben, Remco. "Dutch Memories of Captivity in the Pacific War." In Forgotten Captives in Japanese-Occupied Asia, edited by Karl Hack and Kevin Blackburn, 94-110. London and New York: Routledge, 2008.

Raben, Remco. "Hoe wordt men vrij? De lange dekolonisatie van Indonesië." In Van Indië tot Indonesië, edited by Els Bogaerts and Remco Raben, 13-29. Amsterdam: Boom, 2007.

Raben, Remco. "Koloniale Vergangenheit und postkoloniale Moral in den Niederlanden." In Verbrechen erinnern: Die Auseinandersetzung mit Holocaust und Völkermord, edited by Volkhard Knigge and Norbert Frei, 9o-110. Bonn: C.H. Beck, 2002.

Raben, Remco. "A New Dutch Imperial History? Perambulations in a Prospective Field." BMGN - Low Countries Historical Review 128, no. 1 (2013): 5-30.

Raben, Remco. Wie speekt voor het koloniale verleden? Een pleidooi voor transkolonialisme. Arnhem: Indisch Herinneringscentrum, 2016.

Regenhardt, Jan Willem. Joris Ivens: Hoeksteen van aktieve culturele betrekkingen tussen de Verenigde Staten en Nederlands-Indië. (Kleine scriptie, 1982). u.p. Archived at NIOD Institute of War, Holocaust and Genocide Studies. scr.648.

Reybrouck, David van. Revolusi: Indonesië en het onstaan van de modern wereld. Amsterdam: De Bezige Bij, 2020.

Ricoeur, Paul. Memory, History, Forgetting. Translated by Kathleen Blamey and David Pellaur. Chicago and London: University of Chicago Press, 2004.

Rijnswou, Saskia van. Marion Bloem. Amsterdam: De Arbeiderspers, 1993.

Rosaldo, Renato. “Imperial Nostalgia." Representations 26 (1989): 107-122.

Rosinska, Zofia. "Emigratory Experiences: The Melancholy of No Return." Memory and Migration: Multidisciplinary Approaches to Memory Studies, edited by Julia Creet and Andreas Kitzmann, 29-42. Toronto: University of Toronto Press, 2011. Rushdie, Salman. Imaginary Homelands: Essays and Criticism 1981-1991. Harmondsworth: Granta Books, 1991.

Said, Edward W. Covering Islam: How the Media and the Experts Determine How We See the Rest of the World. London: Vintage, 1997 [1981].

Said, Edward W. Culture and Imperialism. New York, 1994.

Said, Edward W. "Europe and Its Others: An Arab Perspective." In States of Mind: Dialogues with Contemporary Thinkers, edited by Richard Kearney, 39-47. New York: New York University Press, 1995.

Said, Edward W. “Opponents, Audiences, Constituencies, and Community." Critical Inquiry 9, no. 1 (1982): 1-26.

Said, Edward W. Orientalism. London: Penguin Books, 2003 [1978].

Said, Edward W. Out of Place: A Memoir. London: Granta Books, 2000. 
Salverda, Reinier. "De dingen en hun verhaal." In Wandelaar onder de palmen. Opstellen over koloniale en postkoloniale literatuur, edited by Michiel van Kempen, Piet Verkruijsseen and Adrienne Zuiderweg, 213-226. Leiden: KITLV, 2004.

Sars, Paul. Adriaan van Dis: De zandkastelen van je jeugd. Nijmegen: SUN, 1996.

Scagliola, Stef. "De lange schaduw van een verloren oorlog." In Oorlog! Van Indië tot Indonesië 1945-1950, edited by Esther Wils, 36-38. Arnhem: Museum Bronbeek, 2015.

Scagliola, Stef. Last van de oorlog: de Nederlands oorlogsmisdaden in Indonesië en hun verwerking. Amsterdam: Balans, 2002.

Scagliola, Stef. “The Silences and Myths of a 'Dirty War': Coming to Terms with the Dutch-Indonesian Decolonization War (1945-1949)." European Review of History 14, no. 2 (2007): 235-262.

Schmid, Alex P., Janny F.A. de Graaf, Frank Bovenkerk, L. M. Bovenkerk-Teerink and L. Brunt. Zuidmolukse terrorisme, de media en de publieke opinie: Twee studies van her Centrum voor Onderzoekvan Maatschappelijke Tegenstellingen. Amsterdam: Intermediair, 1982.

Schmidt, Benjamin. "Dikes and Dunes: On Dutch History and Dutchness." BMGN - Low Countries Historical Review 133, no. 1 (2018): 82-99.

Schoots, Hans. Living Dangerously: A Biography ofJoris Ivens. Amsterdam: Amsterdam University Press, 2000.

Schulte Nordholt, Henk. "A Genealogy of Violence in Indonesia." In Roots of Violence in Indonesia: Contemporary Violence in Historical Perspective, edited by Freek Colombijn and Thomas Lindblad, 33-61. Leiden: KITLV Press, 2002.

Schulte Nordholt, Henk. "Locating Southeast Asia: Postcolonial Paradigms and Predicaments." In Asia in Europe: Europeans in Asia, edited by Srilata Ravi, Beng-Lam Goh and Marrio Rutten, 36-56. Singapore: ISEAS Publications, 2004.

Scova Righini, A.A. "Een leven in twee vaderlanden: Een biografie van Beb Vuijk." PhD diss., University of Amsterdam, 2004.

Sedikides, Constantine, Tim Wildschut, Jamie Arndt and Clay Routledge. "Nostalgia: Past Present and Future." Current Directions in Psychological Science 17, no. 5 (2008): 304-307.

Seriese, Edy. Finding History: The Inheritance of the IWI Collection: Research Report for PhotoCLEC - Photographs, Colonial Legacy and Museums in Contemporary European Culture, IP2 - Indies Images of the Colonial Everyday in a Multi-Ethnic Postcolonial Society. Amsterdam: Indisch Wetenschappelijke Instituut, 2011.

Shaffer, Deborah and Joris Ivens. "Fifty Years of Political Filmmaking: An Interview with Joris Ivens." Cineaste 14, no. 1 (1985) 12-15, 21.

Smeets, Henk "De plaats van keuze." In Tijdelijk Verblijf:De opvang van Molukkers in Nederland, 1951, edited by Wim Manuhutu and Henk Smeets, 7-16. Amsterdam: De Bataafsche Leeuw, 1991. 
Smeets, Henk. "Sprongen door de Molukse geschiedenis." Indische Letteren 10, no. 1 (1995): 3-12.

Smits, Boudewijn. Loe de Jong, 1914-2005: Historicus met een missie. Amsterdam: Boom, 2014.

Sontag, Susan. On Photography. London. Penguin Books, 2002 [1977].

Sontag, Susan. Regarding the Pain of Others. London: Penguin, 2003.

Steijlen, Fridus. “De Molukkers.” In Een Open Zenuw: How wij ons de Tweede Wereldoorlog herinneren, edited by Madelon de Keizer and Marieke Plomp, 361-370. Amsterdam: Bert Bakker, 2010.

Steijlen, Fridus. RMS: Van ideaal tot symbool - Moluks nationalisme in Nederland, 1951-1994. Amsterdam: Spinhuis, 1996.

Stoler, Ann Laura. Duress: Imperial Durabilities in Our Times. Durham, NC: Duke University Press, 2016.

Stoler, Ann Laura. "Sexual Affronts and Racial Frontiers: European Identities and the Cultural Politics of Exclusion in Colonial Southeast Asia." In Hybridity and Its Discontents: Politics, Science, Culture, edited by Avtar Brah and Annie E. Coombes, 19-55. London and New York: Routledge, 2000.

Stoler, Ann Laura and Karen Strassler. "Casting for the Colonial: Memory Work in 'New Order' Java." Comparative Studies in Society and History 42, no. 1 (2000): 4-48.

Stufkens, Andre. "Joris Ivens: Essays on the Career of a Radical Documentarist: Interview with Thomas Waugh." The Ivens Magazine 18 (December 2013): 30-31.

Swart, Rolf. "De waardigheid van een ernstige schrijver." InJaarboek Letterkundig Museum, 133-142. The Hague: Nederlands Letterkundig Museum en Documentatiecentrum, 1995 .

Thiam, Marie-Helene. "Een wereld vol geesten: Het Moluks animistische volksgeloof in De Tienduizend Dingen." Indische Letteren 15, no. 2 (2000): 68-82.

Tollebeek, Jo. "De zuigkracht van het medium. Historici als televisie deskundigen.” Bijdragen en Mededelingen betreffend de Geschiedenis der Nederlanden 116, no. 4 (2001): 465-482.

Trouillot, Michel-Rolph. Silencing the Past: Power and the Production of History. Boston: Beacon Press, 1995.

Turner, Victor. Blazing the Trail: Way Marks in the Exploration of Symbols, edited by Edith Turner. Tucson and London: University of Arizona Press, 1992.

Turner, Victor. The Ritual Process: Structure and Anti-Structure. New York: Aldine de Gruyter, 1995 .

Turner, Victor and Edith Turner. Image and Pilgrimage in Christian Culture: Anthropological Perspectives. Oxford: Basil Blackwell, 1978.

Vanvugt, Ewald. Roofstaat: Wat iedere Nederlander moet weten. Amsterdam: Nijgh en Van Ditmar, 2015. 
Virilio, Paul. War and Cinema: The Logistics of Perception. Translated by Patrick Camiller. New York and London: Verso, 1989.

Vogel, Jaap. De opkomst van het Indocentrische geschiedbeeld: Leven en werken van B.J.O. Schrieke en J.C. van Leur. Hilversum: Verloren, 1992.

Vree, Daan. "Het verleden voorbij: Jill Stolk in het licht van de naoorlogse dekolonisatie." Indische Letteren 15, no. 1 (2000): 37-46.

Vree, Frank van. "Bilder/Gegenbilder. Kolonialgeschichte und visuale Erinnerungskultuur 1945-1995.” In Kolonialismus und Erinnerungskultuur: De Kolonialvergangenheit im kollektiven Gedächtnis der deutsche und niederlandischen Einwanderungsgesellschaft, edited by Helma Lutz and Kathrin Gawarecki, 181-202. Munster: Waxmann Verlag, 2005.

Vree, Frank van. "De Overval." In Een Open Zenuw: Hoe wij ons de tweede wereloorlog herinneren, edited by Madelon de Keizer and Marije Plomp, 445-454. Amsterdam: Bert Bakker, 2010.

Walder, Dennis. Postcolonial Nostalgias: Writing, Representation and Memory. New York and London: Routledge, 2011.

Waugh, Thomas. The Conscience of Cinema: The Works ofJoris Ivens 1926-1989. Amsterdam: Amsterdam University Press, 2016.

Waugh, Thomas. "Joris Ivens and the Legacy of Committed Documentary." In Joris Ivens and the Documentary Context, edited by Kees Bakker, 171-182. Amsterdam: Amsterdam University Press, 1999.

Wekker, Gloria. White Innocence: Paradoxes of Colonialism and Race. Durham, NC, and London: Duke University Press, 2016.

Wesseling, Henk L. “Post-Imperial Holland." Journal of Contemporary History ${ }_{15}$, no. 1 (1980): 125-142.

Wesseling, Henk L. Van Toen en Nu: Opinies en observaties over politiek, geschedenis en cultuur. Amsterdam: Prometheus-Bart Bakker, 2014.

Wietsma, Anne and Stef Scagliola. Liefde in tijden van oorlog: Onze jongens en hun verzwegen kinderen in de Oost. Amsterdam: Boom, 2013.

Willems, Wim. Introduction to Kind van Batavia, by Tjalie Robinson, 7-11. Amsterdam: Prometeus Books, 2011.

Willems, Wim. Tjalie Robinson: biografie van een Indo-schrijver. Amsterdam: Bert Bakker, 2009.

Willems, Wim. Van wie is de geschiedenis? Bekentenissen van een biograaf. Amsterdam: Bert Bakker, 2013.

Wolthuis, Rob. "Voorlichtingsbeleid met betrekking tot Nederlands-Indië 1945-1950: Picturale 'story-telling' als propaganda middel." MA thesis, Erasmus University Rotterdam, 2008. http://hdl.handle.net/2105/4754. Accessed 6 April 2015.

Woude, Johan van der. Maria Dermoût: De Vrouw en de Schrijfster. The Hague and Rotterdam: Nijgh en Van Ditmar, 1973. 
Zhou, Xinyue, Constantine Sedikides, Tim Wildschut and Ding-Guo Gao. "Counteracting Loneliness: On the Restorative Function of Nostalgia." Psychological Sciences 19, no. 10 (2008): 1023-1029.

Zonneveld, Peter van. "Ik ben de schatbewaarder. Ik ben de fantast:' Gesprek met Adriaan van Dis.” Indische Letteren 18, no. 4 (2003): 207-220.

Zonneveld, Peter van. "Indische literatuur van de twintigste eeuw." In Europa buitengaats. Koloniale en postkoloniale literaturen in Europese talen, 2 vols, edited by Theo D'haen, vol. 1, 133-159. Amsterdam: Bert Bakker, 2002.

Zweers, Louis. De gecensureerde oorlog: Militairen versus media in Nederlands-Indië 1945-1949. Zutphen: Walburg Pers, 2013.

Zweers, Louis. 'Silence Is the Best Solution': The Military versus the Media in the Netherlands East Indies 1945-1949." Newsletter of the International Institute for Asian Studies 68 (Summer 2014): 8-9. 


\section{Index}

Aceh War see Veer, Paul van 't

Achter het Nieuws (Behind the news) 13, 139-44, 147, 149-50, 154, 156, 159, 262; see also Hueting, Joop; Wigbold, Herman

Algemeen Dagblad 34, 41-42, 46, 218, 259, 286 allatonceness see McLuhan, Marshall

Anderson, Benedict $\quad 18,80,89,96,107$

Ankersmit, Frank 11, 21

Anti-Revolutionary Party 109, 119

Assmann, Aleida

on memory and forgetting 18,97

on memory and latency $\quad 143-44$

on memory and literature 20

on memory and place 66

Assmann, Jan 16, 18

Auge, Marc 14, 68, 71

Baay, Reggie $\quad 115-16$

Bank, Jan 127, 16o, 165, 191, 207, 211, 273, 275, 288-91, 299

and Loe de Jong $199,218,226$

and television 136,140

Katholieken en de Indonesische

Revolutie (Catholics and the Indonesian

Revolution) 204-06

Barthes, Roland 94-95

Batavia $27,33,51,125,151,162,206,214-15,223$, 240, 274

and Rob Nieuwenhuys 91, 94

and Tjalie Robinson $\quad 82-83$

Beel in Batavia 205

see also Multifilm Batavia

Baudet, Henri $\quad$ 203, 206, 211

Baudrillard, Jean $\quad 257$

Beatrix, Queen 211, 286, 291-92

Beekman, Eric Montague 89-9o

Beel, Louis $\quad 143,190,201,204-05,215^{-16}$

Berg, Joop van den $\quad 234,236,242,285$

Bersiap period $\quad 22,58,64,86,92,108,139,161$, $180,182,194,258,266$

Bhabha, Homi $\quad 80-81$

Bijl, Paul 96, 138, 158, 301

Bloem, Marion 169, 261, 299

Geen gewoon Indisch meisje (No ordinary Indisch girl) $\quad 183-86$

Het Land van mijn ouders (The country of my parents) 186

Wij komen als vrienden (We come as friends) 193

see also postmemory; hybridity

Bloembergen, Marieke 44, 46, 50-51, 121

Boekholt, Ralph 220-21

Boomsma, Graa $\quad 234-35,269,286,289-90,299$

biography of A. Alberts 281

Boomsma Affair $\quad$ 261-66, 286-87
De Laatste Tyfoon (The last

typhoon) 361-62

Westerling (opera) $\quad 289$

Boon, Jan see Mahieu, Vincent; Robinson, Tjalie Bosma, Ulbe $\quad 65 \mathrm{nn}, 66 \mathrm{nn}, 111 \mathrm{nn}, 172 \mathrm{nn}, 179$, 25on Bouman, Herman $\quad 55,123$

Bourdieu, Pierre

with Passeron, Jean-Claude 207

Breton de Nijs, E. see Nieuwenhuys, Rob

Catholic People's Party (KVP, Katholieke

Volkspartij) 23, 143, 202, 204-05, 274

Chakrabarty, Dipesh see historical wounds cinema

Battle of Algiers $\quad 145-46,158,298$

Gordelvan Smaragd (The emerald belt) 258-26o

Indonesia Calling see Ivens, Joris

newsreels 28-29

Brengers van Recht en Veiligheid (Bringers of justice and security) 29

Het Vreemde Leger (The strange army) 30-31

Linggadjati in de branding (Linggadjati burning) 30

Oud en Nieuw in Indonesië (Old and new in Indonesia) 30

Soldaat Overzee (Overseas soldier) 29

Oeroeg [the film] 252-58, 26o

comparison with Hollywood $\quad 257-58$

criticism of $255^{-5} 6$

positive reactions to $254-55$

see also Baudrillard, Jean

see also Multimedia Batavia

circles of esteem 207, 299, 326

Comité Actie Minderheden (Minorities Action

Committee) 174

Comité Geschiedkundig Eerherstel (Committee

for Historical Rehabilitation) $\mathbf{2 2 0}$

communitas see liminality

Connerton, Paul 14, 92

on house and city as loci of memory $\quad 66-67$

on memory and forgetting $18,194-95$

on memory and technology 135

on memory and texts 20

Cooper, Frederick 200

Cribb, Robert see circles of esteem

De Bezetting see television

De Groene Amsterdammer $\quad 32,35,46,103,219$, 222, 226, 254-55, 260, 263, 269-70, 281

De Stuw group 51-52,110-11, 201-02

De Telegraaf 106, 111, 149, 216, 218, 252, 259

De Volkskrant 34, 139, 204, 206, 218-19, 221-22, 259, 263-64, 267-69, 275, 285-89, 301, 303 
Declaration of Independence $11,13,37,46,102$, 123-24, 193, 200, 272, 286, 291

Dermoût, Maria $\quad 11,13,63,67-80,92,97,107,282$ colonial point of view $\quad 76-79$ cultural appropriation $\quad 74-76$

De tien duizend dingen (The ten thousand things) $68,70-71,73-80$ title of 76 influence of Aldous Huxley $\quad 76$ Nog pas gisteren (Only yesterday) 67-70, 75,78 nostalgia $\quad 71-74$

Derrida, Jacques 14, 19n

Dienst voor Legercontacten (DLC, Army Contact Service) 27, 30-33

Dis, Adriaan van $169,181,187,261,290$ Indische Duinen $187,190,266-67$ Nathan Sid $\quad 187-90$ see also postmemory

Doel, Henk [W.H.] van den $59,127,300$

Dolle, Esther ten 108-o9, 266

Door de Eeuwen Trouw (Loyal through the Centuries) 172, 174

Doorn, Jacques [J.A.A.] van 111, 149, 194, 222, 239, 265-66, 290

De laatse eeuw van Indie (The last century of the Dutch East Indies) 282-84 Ontsporing van Geweld (Derailment of violence) $160-163,200,211,265$ with Hendrix, Wim $\quad 23,149,160-63,211$, 251, 265-66

Drees, Willem 31, 54, 58-59, 142-43, 205

Drooglever, P.J. $\quad 219,275,288-89$; see also Officiële Bescheiden betreffende de Nederlands-Indonesische Betrekkingen 1945-1950

Ducelle, Lilian $88,90,220$

Enthoven Report $\quad 215$

Erll, Astrid 17-18, 135

Esterik, Chris van 260 with Twist, Kees van 190

Excessennota, De (List of excesses) 149-50, 154, 159, 162-63, 192, 203, 211, 226, 271, 288; see also Fasseur, Cees

excesses $35,53,79,104,108,113,149-50,15^{2}$, $154,156,160-63,165,202-04,211,215-16,222$, 224-27, 245, 253, 257, 265, 270-72, 276, 282; see also war crimes

Fanon, Frantz $\quad 81,100-01$ on lactification 101,185 see also hybridity

Fasseur, Cees 149-50, 159, 203, 207, 210-13, 279, 287, 290-91; see also Excessennota; guild, historical; circles of esteem

Foray, Jennifer $\quad$ 9, 57, 118-19, 209

formulas of erasure 79

Freriks, Kester $\quad 97,182$
Gennep, Arnold van 246; see also liminality

Gerbrandy 113, 120, 171-72, 206, 212 Indonesia 109-111

Gerretson, Carel $\quad$ 51, 106-07, 111, 171

Goedhart, Frans $\quad 23-34,35-36,112,143,226$; see also Hoen, Pieter't

Gouda, Frances $\quad$ 148, 209, 228

Graaf, H.J. 124

Graaff, Anton P. de $\quad 234,237-46,251,272,280$, 286; see also liminality

Groen, Petra $\quad$ 271, 283-84, 289-90, 299 Marsroutes en Dwaalsporen (Marching routes and false trails) $\quad 276-80$

Groenwout, Eric van 't 40

guild, historical $199,207-13,228,234,238,242$, 248, 252, 261, 270, 276-77, 279-80, 290, 297, 298-301, 303

Haasse, Hella 118,328 Oeroeg [the book] 28, 43-51, 104; see also cinema, Oeroeg [the film]

Halbwachs, Maurice $15-16,73,91-92,144$

Hatta, Muhammad $\quad 22,56,57,99,124,142,144$, 164-65, 193

Heffernan, Margaret see wilful blindness

Hendrix, Wim see Doorn, Jacques [J.A.A.] van

Heshusius, C.A. $\quad$ 221, 223, 226, 279

Het Parool $32-34,41,56,85,142,144,226,259$, $272,275,287$

Hildering, Pastor 35, 142-43

Hirsch, Marianne $\quad 17,93,170,176$; see also postmemory

historical wounds $173,178,195$

Hoek, Anne Lot 208-09, 212, 275, 301

Hoen, Pieter't $\quad 33-34,36 n$; see also Goedhart, Frans

Hoffman, Eva 169; see also postmemory

Hofland, Henk 124, 222-23, 234, 290

Hoge Veluwe Conference $23,53,58,125,204$, 206

Hogenkamp, Bert 38-40

Hoogte, Albert van der 207 Het Laatste Uur (The final hour) 104-09

Houben, Vincent $\quad 287-88$

Hueting, Joop $135,163,251,253-55,269-70$

Hueting effect 250

Hueting interview $13,139-44,154,156-58$, 160-61, 163, 191-92, 194, 200, 211-12, 222, 226, 257, 261, 265, 273, 288, 297-99 motivation behind interview 144-47; see also Excessennota

Huxley, Aldous see Dermoût, Maria

hybridity $80-81,187,298$

Hylkema, Hans 44, 233; see also cinema, Oeroeg [the film]

IJzereff, Willem $\quad$ 164, 192-93, 213-17, 265

Ivens, Joris 145,299

Indonesia Calling $\quad 27,30,37-43$ 
Jansen Hendriks, Gerda $\quad 28,30-31,38$

Jaquet, L.G.M. 202-03

Jong, Joop de 111 236, 251, 280, 287, 290-91, 299 Diplomatie of strijd (Diplomacy or conflict) $\quad 273-75,285$

Jong, Loe de $\quad 13,122,135-36,159-60,244-45$, 256, 279, 286, 291, 299-300

De Bezetting (The occupation) 136-39, 148, $157-58,199,219,221,257$

Loe de Jong Controversy 199-200, 217-28, 233-35, 239, 279, 281, 286

see also television, De Bezetting (The occupation); excesses; war crimes

Jonkman, J.A. 201-02, 215

Kaam, Ben van $\quad 179-80$

Kadt, Jacques de $\quad 13,102,123,206,283$

De Indonesische tragedie (The Indonesian tragedy) $\quad 55^{-59}$

Kampenhuis, Piet $\quad 280,303$

Katholieke Volkspartij (KVP) see Catholic People's Party

Kiers, Roelof $\quad 164-65,193,207,266,272,299$

KITLV - Koninklijk Instituut voor Taal-, Land- en Volkenkunde/Royal Netherlands Institute of Southeast Asian and Caribbean Studies 9, 122, 201, 209-12; see also guild, historical

KNIL - Koninklijk Nederlandsch-Indisch Leger (Royal Netherlands East Indies Army) 35, 142, 162, 170-71, 174-75, 178, 180, 188, 243-45, 289, 291

Kousbroek, Rudy $\quad 97,148,208,255,273,278$, 282

Kuitenbrouwer, Maarten 210

Kwantes, R.C. $\quad$ 16on, 218-19

Labour Party $\quad 23,33,56,110-11,142,202,215$

Laurens, Ben $13,223,234-37,247-48,250-51$, $262,280,299$

Leiden 124-25, 203; see also KITLV

Lijphart, Arend 126-27, 146-47, 211

liminality $\quad 246-52$

Limpach, Remy 301

Linggadjati Agreement $\quad 23-24,53,58,111,125$, 206

literature

as stabilizer of collective memory $\quad 20-2$ salvaging cultural memory 83

trauma literature 184

Locher-Scholten, Elsbeth $159-60,219,265$, $283,287,290$

Logemann, Johan $\quad 5^{2-53}, 58,110,202$

Mahieu, Vincent $\quad 82,85-90,103,207$; see also Robinson, Tjalie

McLuhan, Marshall allatonceness $136-37,139-40$

Meines, Ted 250, 269-70 memory

and silences $\quad 18-19,64-65,136,141,169-70$, 181-82, 184, 190-92, 195, 207, 209, 228, 234, 265-66, 271, 276, 297; see also formulas of erasure

collective memory $\quad 9,11,13,15-22,32,38$, $43,50,63-64,67,80-82,86,90,93,135$, $139,143,147-48,170,173,179,182-83$, 186, 199, 228, 233, 283, 290, 297; see also Assmann, Aleida; Assmann, Jan: Connerton, Paul; Halbwachs, Maurice; Olick, Jeffrey; Ricoeur, Paul

contested memory $\quad 13,27,199,228,233$, 286, 297, 299-301

cultural memory $\quad 66,83$

embodied memory $\quad 71,189-90,253$

prosthetic memory 71

public memory $\quad 252,256-57$

repetition memory $16,50,55,72$

salvage memory $\quad 82-83,85,91-92,297-98$

traumatic memory 18,72

see also nostalgia; postmemory; unremembering

Meulen, Daniel van der $\quad 125-26$

Moesson 220-21; see also Tong-Tong

Moluccan actions $169-80,195,228,283$, 297, 301-02; see also historical wounds, postmemory

as postmemory struggle $\quad 177-79$

comparison with other liberation movements $\quad 174-76$ impact of $179-80$

Mook, Lieutenant Governor-General Hubertus J. van $23,27,30,37,56-58,110-11,113$, 125-26, 162, 165, 201-02, 204-06, 214-15, 274 Indonesië, Nederland en de Wereld

(Indonesia, the Netherlands and the world) $\quad 5^{1-55}$

Moor, Jaap de $\quad 213,280$

Morriën, Joop $\quad 216-17,267,275$

Mountbatten, Lord $\quad 22,110$

Multifilm Batavia $\quad 28$

Nationaal Comité Handhaving Rijkseenheid (National Committee for Maintaining State Unity) 111

Nieuwsblad van het Noorden $\quad 145,216,222$, 226

and the Boomsma Affair $\quad 262-63$

nostalgia $46,63,80-81,193,251,282,297-98$

and Eurocentrism $\quad 72-73$

colonial nostalgia $\quad 50-51,72$

in the novels of Maria Dermoût $\quad$ 71-74

in the photograph collections of Rob

Nieuwenhuys 96-97

see also Rosaldo, Renate

NRC Handelsblad $35,122,142,144,187,203$, $216,218,222-23,238,259,264-65,268,271$, $274,285,287$ 
Olick, Jeffrey $\quad 17,136$

Oostindie, Gert $\quad 9,64 \mathrm{n}, 65 \mathrm{nn}, 116-17,121,183 \mathrm{n}$, 185 , 200n, 227, 237n, 250, 303

Orientalism $30,47-48,72,74-76,116,210,257$, 282

Oriëntatie (Orientation) $46,82,85,91$

Passeron, J.-C. see Bourdieu, P.

Pattynama, Pamela $\quad 21,47,70-72,90,93$, 252-53, 257

photography $135,184,213,243,259,276$ and family life $\quad 95-97$ and melancholy $\quad 94-95$ and nostalgia 97 as evidence of atrocities $\quad 32,95-96,138$, 301-02

as metaphor 92

as propaganda $\quad 31-32$

as prosthetic memory $\quad 71$

certifying experience 95

gives illusions of continuity 93

in Breton de Nijs' Tempo Doeloe:

Fotografische documenten uit het oude

Indië 1870-1914 (Olden days: Photo-

graphic documents from the old Indies, 1870-1914) 92-98

in Hylkema's Oeroeg [the film] $257-5^{8}$

in Loe de Jong's De Bezetting 138, 257

in Van 't Veer's De Atjeh-oorlog (The Aceh war) $157-5^{8}$

mediating experience $\quad 184,189$

see also Barthes, Roland; Bijl, Paul; Dienst voor Legercontacten (DLC, Army

Contact Service); Protschy, Susie; postmemory; Sontag, Susan; Zweers, Louis

pilgrimage $\quad 247-49,272$

Poeze, Harry $116,119,201,288$

"Police Actions" 12, 24, 49-50, 65, 112, 118, 123 , $126,154,174,182,235-36,243,251,264-65$, 268-69, 276, 278, 287, 298

Poncke Princen 193, 286

Poncke Princen Affair $\quad 233,267-70,286$, 299

Pontecorvo, Gillo see cinema, Battle of Algiers postcolonial $14,19,40,47,49,69,81,90,122$, $148,169,174,179,183-84,188,228,243,251$, $253,298,300$

postmemory $14,17,169-70,174,181,183,193$, 228, 238, 297-98

postmemory activism $\quad 174,195,298$

postmemory authors

Bloem, Marion 183-86

Boomsma, Graa 261-62

Dis, Adriaan van $\quad 187-90,266-67$

Stolk, Jill 181-83

see also Hirsch, Marianne

post-traumatic stress disorder 250; see also liminality
Praamstra, Olf $\quad 70-71,74 n, 75,77-78,102-03$

Protschky, Susie 32,96

Putten $35,143,193-95,264$

Raben, Remco $\quad 9,63 n, 65 n, 66 n, 135-36,147-48$, 200, 206, 208, 301-02

radio $11,14,21,27,111,135,145,151,169,175,195$, 208, 246, 264, 271, 290, 297-98

Daar werd iets grootsch verricht (Something great was achieved there) 19on, 277

De kleine oorlog (The little war) 190-92, 301

Het spoor terug: Afscheid van Indië (The way back: Goodbye to the Dutch East Indies) 194

Randwijk, Henk van $30,36,46,119$

Rawagede or Rawagedeh $192,228,233,271-72$, 288, 301-02

Regenhardt, Jan Willem $\quad 42-43$

Renville Agreement $\quad$ 24, 206

Republic South Moluccas see Republik Malaku Seletan

Republik Malaku Seletan (RMS, Republic South Moluccas) 171-72, 174, 179-8o

Reybrouck, David van 103,210

Ricoeur, Paul 16-17, 50, 67, 72,148

Rijksvoorlichtingsdienst (RVD, Government Information Service) $\quad 28$

Romein, Jan 64

Romme, Carl 204-05, 215-16; see also Catholic People's Party

Rosaldo, Renato 72-73

Rushdie, Salman $\quad 67,72,81$

Said, Edward $\quad 17,47,76-77,108 \mathrm{nn}$ on cultural archive $\quad 21,72$

on guilds $208,212 \mathrm{n}, 279$

on hybridity $80-81$

on Orientalism $30,47-48,72$

post-Saidian 14

Sars, Paul $187,188 \mathrm{n}, 190,267 \mathrm{n}$

Scagliola, Stef $108-09,114 \mathrm{n}, 115,118,121 \mathrm{n}, 207$, 270, 278, 300-02

Schilt, Jan $\quad 15^{0-53}, 155^{-5} 6,207,235,251,262$, 268

Schoots, Hans $37 \mathrm{nn}, 38-40,41 \mathrm{n}, 42 \mathrm{n}$

Schulte Nordholt, Henk 9, 63n, 210, 293, 300

Schulte Nordholt, Nico $\quad 251,269,290$

Seunke, Orlow see cinema, Gordel van Smaragd (The emerald belt)

Sjahrir 34, 99

Sjarifuddin, Amir 34

Smeets, Henk 17inn, 172

Smits, Boudewijn $\quad 137 \mathrm{n}, 199-200,220,228$

Sontag, Susan 31, 94-95

South Celebes $53,112-15,124,162-64,213-18$, 225, 227-28, 264, 270, 288, 301; see also IJzereef, Willem; Westering, Captain Raymond 
Spoor, Lieutenant-General S.H. $\quad 27,35,114,152$, $162,190,202,214,225,227,245,251,277,284-85$

Steijlen, Fridus $\quad 64 n, 171 n, 172-73,175,178 n$, 179, 180

Stoler, Ann Laura $\quad$ 18-19, 45n, 115-16

Stolk, Jill $\quad 181-83$

Sukarno 22-23, 37-38, 52-53, 55-57, 99, 102, $118-19,123-25,148,156,161,165,193-94$, 200-04, 214, 281, 286

Surabaya $108,193,287$

Sytzen, Job $\quad 116-21,150,207,251,299$

Tan Malaka see Poeze, Harry

television 11, 14-15, 20-21, 42, 86, 90, 127, $135-36,147,150,15^{2}, 169,173,195,199,228$, $233,236,244,257-58,262,268-69,278-79$, 284-86, 290-91, 297-99, 303

Antenne: Korban (Antenna korban) 177 De Bezetting (The occupation) see Jong, Loe de, De Bezetting (The occupation)

De Excessen van Rawagedeh (The excesses of Rawagede) 271-72

De Kampong staat in brand (The kampong is burning) 270-71

De tijd staat stil: De Zuidmolukse droom (The time has stopped: The South Moluccan dream) 175n, $177 \mathrm{n}$

Dutch Approach 177

En Wij, wij leven voort in een doolhof (And we, we live on in a maze) $\quad 163$

Het Land van mijn Ouders (Country of my parents) 186

Hier is ... Adriaan van Dis (Here is ... Adriaan van Dis) $\quad 187$

Indonesia Merdeka $\quad 164-65,193,266,271-72$

"Ons Indië" voor de Indonesiërs ("Our Indies" for the Indonesians) 192-93

Ontsporing van Geweld (Derailment of violence) 163

Tabee Toean: Op patrouille in NederlandsIndië (Tabee Toean: On patrol in the

Dutch East Indies) 272-73

VeertigJaar na Dato - Nederlands Indië (Forty years later - the Dutch East Indies) 193-94

Wij komen als vrienden (We come as friends) 193

see also: Achter het Nieuws (Behind the news); Baudrillard, Jean; Hueting Joop,

Hueting interview; McLuhan, Marshall; Wigbold, Herman

Tong-Tong 9o, 93, 220; see also Moesson

Trouillot, Michel-Rolph 14, 54-55, 79, 207, 209, 278,28 on

Trouw 217, 221, 259, 264, 275, 285-87, 289

Turner, Edith see Turner, Victor

Turner, Victor 14, 247-48; see also liminality

with Turner, Edith 248

Twist, Kees van see Esterik, Chris van unremembering $11,13,15,27-28,63,112-13$, $115-18,121,135,139,143,144,147,156,159,161$ $169,183,185,187,189,195,199-200,215,228$, 233-34, 238-39, 261-62, 297-99 and Indonesia Calling 39 and Oeroeg [the novel] $5^{0-51}$ and Vuyk's work 104

German occupation dominating memory $19-20,36-37,118-19,139,148$

in book reviews $\quad 156-59$

in Breton de Nijs/Nieuwenhuys' work $97-98$

in Dermoût's work $\quad 70,73-74$

in film $256-58,260$

in film reviews $145-46$

in Robinson/Mahieu's work $82-85$, 89-9o

in the work of historians $124,159,206$, 212-13, 216, 220, 238, 248, 251, 274-75, 280,303

in Van Mook's work 55

meaning of 18-20

Moluccan struggle against $\quad 173-80$

versus aphasia 19

versus forgetting 18-19

see also Excessennota; guild, historical

Vanvugt, Ewald $\quad 206,290,301$

Varenne, Jan $154-56,207,235,247-48,251$, 262

Veen, F. van der $\quad 225,227-28,279$

Veer, Paul van 't $\quad 111,211$

biography of Sukarno 125

De Atjeh-oorlog (The Aceh war) 156-59

Verheul, Tom 272

veterans $12-13,17,21,32,63,86,116,193-195$, 200, 271-72, 276, 278, 280, 283, 287, 289, 291, 297-99, 303; see also Boomsma Affair; De kleine oorlog; Hueting, Joop; Laurens, Ben; liminality; Jong, Loe de, Loe de Jong Controversy; Graaff, Anton P. de; Poncke Princen Affair; Schilt, Jan; Sytzen, Job; Varenne, Jan; war crimes; Zwaan, Jacob

Virilio, Paul 27

Vree, Frank van 137, 139

Vrij Nederland $\quad 30,32,36,119,206,214-15$, 225-26

war crimes $35,5^{0}, 115,121,139-44,149-15^{0}, 157$, $159,161-63,165,191-92,194-95,211-12,216$, 221-28, 233, 241, 244-46, 265, 267, 278-8o, 287-91, 298, 301; see also excesses; Hueting Joop, Hueting interview; IJzereff, Willem; Jong, Loe de, Loe de Jong Controversy; Westering, Captain Raymond

Waugh, Thomas 38-39

Wertheim, Wim 21, 102,122n, 123

Wesseling, Henk 127, 137n, 149, 173n, 207, 210, 291 
Westerling, Captain Raymond $\quad 125,162,194$ 204, 213-17, 224-25, 264-65, 270-71, 276, 278 memoir of $\quad 112-15$

Westerling (opera) $\quad 289$

see also South Celebes

Wietsma, Anne 115-16

Wigbold, Herman $\quad$ 140-43, 192, 207, 270-71, 286, 299

wilful blindness $\quad 207$
Willems, Wim $\quad 64 \mathrm{nn}, 65,66 \mathrm{nn}, 82-84,86 \mathrm{n}$, 89n, 9on

Woude, Johan van de $75 \mathrm{nn}, 76 \mathrm{n}$

Zonneveld, Peter van $\quad 97,181 \mathrm{nn}, 189 \mathrm{n}$

Zwaan, Jacob $\quad$ 152-56, 207, 235, 251, 262, 276

Zweers, Louis 27nn, 28, 29n, 31n, 32, 34, 209-10, 287

Zwitzer, H.L. $\quad$ 222, 279, 285 